\title{
Hydrothermal Alteration in the Mount Hood Area, Oregon
}

\section{U.S. GEOLOGICAL SURVEY BULLETIN 2054}




\section{AVAILABILITY OF BOOKS AND MAPS OF THE U.S. GEOLOGICAL SURVEY}

Instructions on ordering publications of the U.S. Geological Survey, along with the last offerings, are given in the current-year issues of the monthly catalog "New Publications of the U.S. Geological Survey." Prices of available U.S. Geological Survey publications released prior to the current year are listed in the most recent annual "Price and Availability List." Publications that are listed in various U.S. Geological Survey catalogs (see back inside cover) but not listed in the most recent annual "Price and Availability List" are no longer available.

Prices of reports released to the open files are given in the listing "U.S. Geological Survey Open-File Reports," updated monthly, which is for sale in microfiche from the U.S. Geological Survey Books and Open-File Reports Sales, Box 25286, Denver, CO 80225.

Order U.S. Geological Survey publications by mail or over the counter from the offices given below.

\section{BY MAIL}

\section{Books}

Professional Papers, Bulletins, Water-Supply Papers, Techniques of Water-Resources Investigations, Circulars, publications of general interest (such as leaflets, pamphlets, booklets), single copies of periodicals (Earthquakes \& Volcanoes, Preliminary Determination of Epicenters), and some miscellaneous reports, including some of the foregoing series that have gone out of print at the Superintendent of Documents, are obtainable by mail from

\section{U.S. Geological Survey, Books and Open-File Reports Sales Box 25286 \\ Denver, CO 80225}

Subscriptions to periodicals (Earthquakes \& Volcanoes and Preliminary Determination of Epicenters) can be obtained ONLY from

\section{Superintendent of Documents \\ U.S. Government Printing Office Washington, DC 20402}

(Check or money order must be payable to Superintendent of Documents.)

\section{Maps}

For maps, address mail orders to

\section{U.S. Geological Survey, Map Sales Box 25286 \\ Denver, CO 80225}

Residents of Alaska may order maps from

\footnotetext{
U.S. Geological Survey, Map Sales 101 Twelfth Ave., Box 12

Fairbanks, AK 99701
}

\section{OVER THE COUNTER}

\section{Books}

Books of the U.S. Geological Survey are available over the counter at the following U.S. Geological Survey offices, all of which are authorized agents of the Superintendent of Documents.

- ANCHORAGE, Alaska-4230 University Dr., Rm. 101

- LAKEWOOD, Colorado-Federal Center, Bldg. 810

- MENLO PARK, California-Bldg. 3, Rm. 3128, 345 Middlefield Rd.

- RESTON, Virginia-National Center, Rm. 1C402, 12201 Sunrise Valley Dr.

- SALT LAKE CITY, Utah-Federal Bldg., Rm. 8105, 125 South State St.

- SPOKANE, Washington-Rm. 135, U.S. Post Office Bldg., W. 904 Riverside Ave.

- WASHINGTON, D.C.-U.S. Department of the Interior Bldg., Rm. 2650, 1849 C St., NW.

\section{Maps}

Maps may be purchased over the counter at the U.S. Geological Survey offices where books are sold (all addresses in above list) and at the following Geological Survey offices:

- ROLLA, Missouri-1400 Independence Rd.

- FAIRBANKS, Alaska-New Federal Building, 101 Twelfth Ave. 


\section{Hydrothermal Alteration in the Mount Hood Area, Oregon}

By Keith E. Bargar, Terry E.C. Keith, and

Melvin H. Beeson

U.S. GEOLOGICAL SURVEY BULLETIN 2054

A study of late Tertiary hydrothermal alteration corresponding to zeolite-facies to greenschist-facies metamorphism and

Quaternary hydrothermal and fumarolic minerals from

outcrops and geothermal drill holes near Mount Hood, Oregon

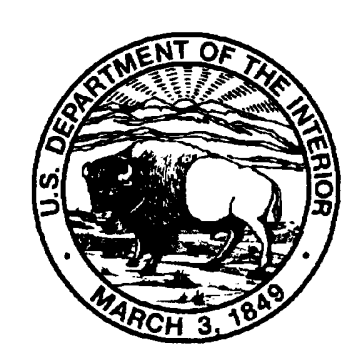

UNITED STATES GOVERNMENT PRINTING OFFICE, WASHINGTON : 1993 


\title{
U.S. DEPARTMENT OF THE INTERIOR BRUCE BABBITT, Secretary
}

\author{
U.S. GEOLOGICAL SURVEY
}

Dallas L. Peck, Director

For sale by the Books and Open-File Report Sales

U.S. Geological Survey

Federal Center, Box 25286

Denver, CO 80225

Any use of trade, product, or firm names in this publication is for descriptive purposes only and does not imply endorsement by the U.S. Government

Text and illustrations edited by James W. Hendley II

Library of Congress Cataloging in Publication Data

Bargar, Keith E.

Hydrothermal alteration in the Mount Hood area, Oregon / by Keith E. Bargar, Terry E.C. Keith, and Melvin H. Beeson.

p. cm. - (U.S. Geological Survey bulletin ; 2054)

Includes bibliographical references.

Supt. of Docs. no.: I 19.3:2054

1. Hydrothermal alteration-Oregon-Hood, Mount, Region. 2. Geology, Stratigraphic-Tertiary. I. Keith, Terry E.C. II. Beeson, Melvin H. III. Title. IV. Series.

QE75.B9 no. 2054

[QE390.5]

$557.3 \mathrm{~s}-\mathrm{dc} 20$

[549.9795'61] 


\section{CONTENTS}

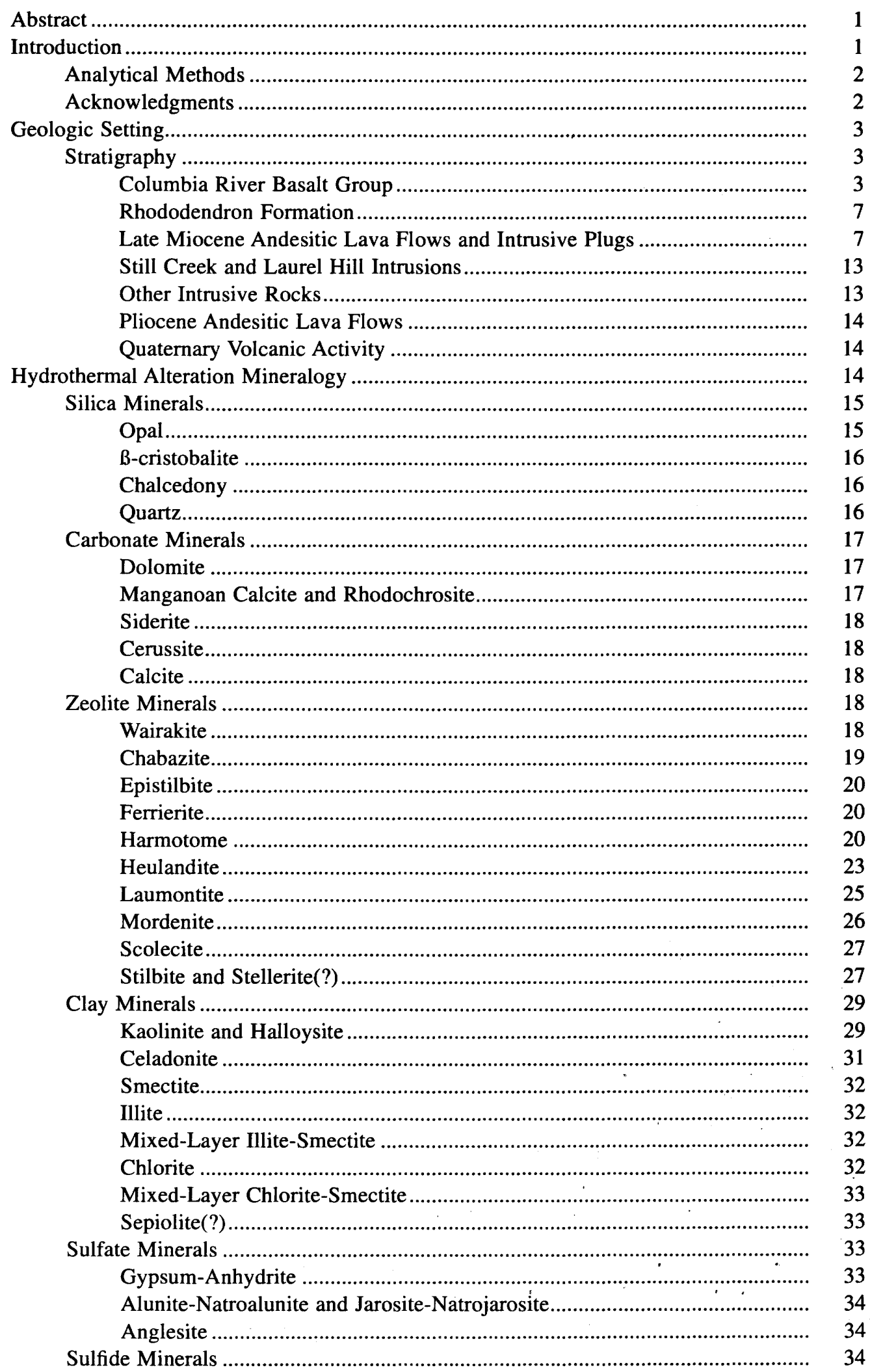


Galena and Sphalerite ......................................................................... 34

Chalcopyrite ........................................................................................ 34

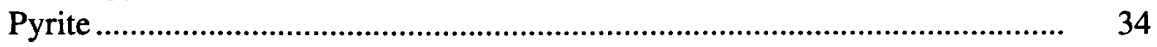

Iron Oxide-Hydroxide Minerals......................................................................... $\quad 35$

Amorphous Iron Oxide-Hydroxide ......................................................... $\quad 35$

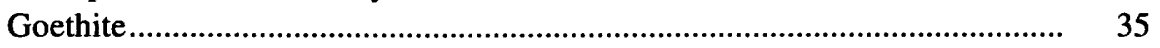

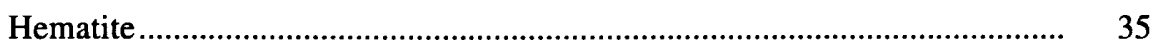

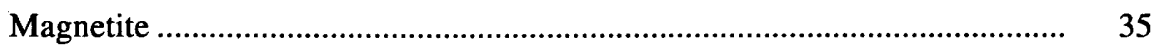

Other Minerals................................................................................................... 36

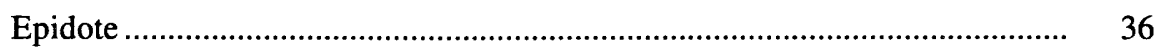

Titanite(?) ........................................................................... 36

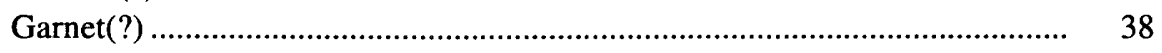

Truscottite(?) ........................................................................... 38

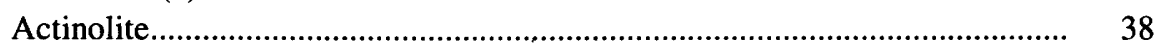

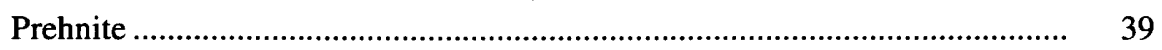

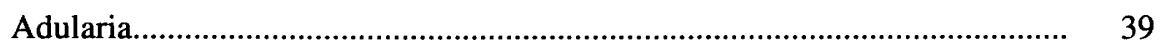

Tourmaline and Apatite ..................................................................... 40

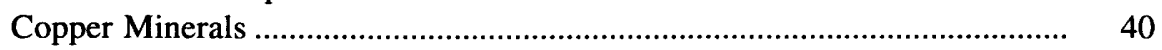

Fluid Inclusions.......................................................................................... 41

Discussion ................................................................................................ 42

Tertiary Metamorphism .............................................................................. 45

Greenschist- and Subgreenschist-Facies Metamorphism............................ 45

Zeolite-Facies Metamorphism ............................................................... 46

Quaternary Metamorphism .................................................................... 48

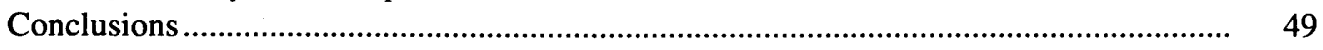

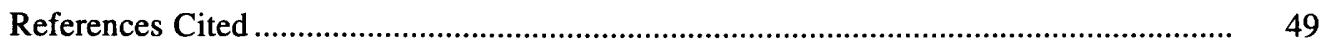

Appendixes:

A. Lithologic Descriptions and Distribution of Hydrothermal Minerals in

Selected Mount Hood Geothermal Drill Holes....................................
B. Hydrothermal Minerals Identified from Geothermal Drill Holes and

Outcrops in the Mount Hood Area............................................................... 70

\section{FIGURES}

1. Topographic map of the Mount Hood area, showing the location of geothermal drill holes included in this report and other geothermal gradient drill holes in the vicinity of Mount Hood ................................... 4

2. Photograph showing Mount Hood from Elk Meadows ............................................................................. 5

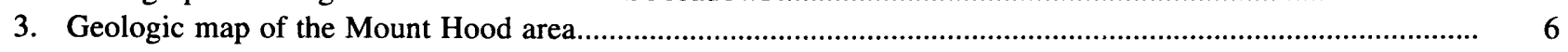

4. Photograph showing lateral moraine deposits below Coe Glacier ...................................................... 15

5-22. Scanning electron micrographs showing:

5. Botryoidal aggregates of rhombic dolomite crystals from the McGee Creek drill hole......................... 17

6. An acicular cerussite crystal from a tailings pile in the Cheeney Creek Mining Area ............................. 18

7. Subhedral wairakite crystals and later chlorite vein filling in specimen 79CCQ-2001B......................... 19

8. Pseudocubic chabazite crystals coated by a thin layer of botryoidal blue-green chrysocolla

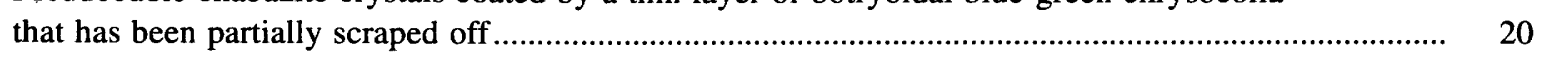

9. Euhedral epistilbite crystals from the Zigzag River drill hole .......................................................... 23

10. Lamellar crystals and prismatic needles of ferrierite from an outcrop near Barlow Pass ...................... 24

11. Harmotome (phillipsite group) crystals from the abandoned Cheeney Creek Mining Area..................... 24

12. Blocky heulandite crystals from the McGee Creek drill hole ............................................................... 25

13. Open-space filling of euhedral laumontite prismatic crystals from the Pucci Chairlift drill hole ............ 26

14. Euhedral, acicular scolecite crystals from a fracture filling in a lava flow of the

Rhododendron Formation 
15. Euhedral, tabular stilbite crystals in drill cuttings from the Pucci Chairlift drill hole.

16. Euhedral, columnar stellerite(?) crystals from altered volcanic rocks of the Rhododendron Formation.....

17. Euhedral columnar crystals of epidote from the Zigzag River drill hole

18. Imperfectly formed, trapezohedral garnet(?) crystal from the McGee Creek drill hole

19. Lamellar crystals of truscottite(?) deposited as radial concentrations on an erratic rock sample collected from the northeast side of Mount Hood

20. Euhedral, equant adularia crystals from fracture fillings in Tertiary volcanic breccia near Iron Creek.......

21. Radiating sprays of acicular tourmaline crystals in a lava flow of the Rhododendron Formation......

22. A grain of native copper from the Lost Creek drill hole

23-27. Photomicrographs showing:

23. Liquid-rich, secondary fluid inclusions in hydrothermal quartz from a fracture in an outcrop of the Rhododendron Formation

24. Secondary, liquid-rich fluid inclusions in a hydrothermal quartz crystal that was deposited in open space of a Tertiary volcanic breccia

25. An isolated, monophase-vapor fluid inclusion having a negative crystal shape

26. A large, relatively saline, primary(?), liquid-rich fluid inclusion from a hydrothermal quartz crystal that was deposited near Iron Creek

27. A large, primary(?), vapor-rich fluid inclusion in hydrothermal quartz from a Tertiary volcanic breccia near Iron Creek

28. Histograms of fluid-inclusion homogenization temperatures of six hydrothermal quartz samples from drill-hole cuttings and outcrops near Mount Hood

29. A plot of homogenization temperatures (Th) versus melting point temperature measurements $(\mathrm{Tm})$ for fluid inclusions in hydrothermal quartz crystals from drill-hole cuttings and Tertiary outcrop samples collected near Mount Hood

\section{TABLES}

1. Geothermal drill holes near Mount Hood, Oregon selected for hydrothermal mineralization studies

2. Chemical analyses of volcanic rocks from the Mount Hood area

3. Electron-microprobe analyses of wairakite from outcrops associated with the Laurel Hill intrusion

4. Electron-microprobe analyses of chabazite from drill hole and outcrop samples associated with the Laurel Hill intrusion

5. Water-content (in wt percent) and trace-element (in ppm) analyses of selected zeolite minerals from outcrops and drill holes near Mount Hood

6. Electron-microprobe analyses of epistilbite from the Zigzag River drill hole (table 1, No. 8) near Mount Hood

7. Electron-microprobe analyses of harmotome from the Cheeney Creek area, southwest of Mount Hood

8. Electron-microprobe analyses of heulandite from a fracture filling in a lava flow of the

Rhododendron Formation near the Laurel Hill intrusion

9. Electron-microprobe analyses of laumontite from fractures in volcanic rocks of the

Rhododendron Formation adjacent to the Laurel Hill intrusion

10. Electron-microprobe analyses of scolecite from outcrops and drill holes near Mount Hood ................................ 28

11. Electron-microprobe analyses of stilbite associated with the Laurel Hill intrusion ............................................. 30

12. Electron-microprobe analyses of stellerite(?) from the Zigzag River drill hole

13. Electron-microprobe analyses of pyrite from mineralized fault zones in Tertiary volcanic rocks near Mount Hood

14. Electron-microprobe analyses of epidote from drill holes and outcrops near Mount Hood

15. Electron-microprobe analyses of actinolite from volcanic rocks of the Rhododendron Formation associated with the Laurel Hill intrusion

16. Electron-microprobe analyses of adularia from near Mount Hood .

17. Fluid-inclusion heating/freezing data for hydrothermal quartz crystals from drill holes and outcrops near Mount Hood 


\title{
Hydrothermal Alteration in the Mount Hood Area, Oregon
}

\author{
By Keith E. Bargar, Terry E.C. Keith, and Melvin H. Beeson
}

\begin{abstract}
Thirty geothermal test drill holes were completed between 1976 and 1980 as part of an investigation of geothermal energy potential in the Mount Hood area. Active thermal features, consisting of near-summit fumaroles and warm springs at the southern base of Mount Hood, suggest the presence of a geothermal resource. The low flow volume of water in even the highest potential drill holes apparently has discouraged further geothermal studies. Nonetheless, the Mount Hood geothermal drilling program generated much geological, geophysical, geochemical, and mineralogical data.

Hydrothermal alteration minerals identified from outcrop and drill-hole-cuttings samples in the Mount Hood area suggest that some late Tertiary volcanic rocks experienced geothermal temperatures corresponding to very low grade metamorphism over a temperature range comprising zeolite- to greenschist-facies metamorphism $\left(\sim 50^{\circ} \mathrm{C}\right.$ to $400^{\circ} \mathrm{C}$ ). The higher greenschist-facies temperatures of this metamorphism appear to have been confined to narrow halos surrounding intrusions that have K-Ar ages of about 8 to $11 \mathrm{Ma}$ and $\sim 5 \mathrm{Ma}$. The late Miocene quartz diorite to quartz monzonite Laurel Hill and Still Creek intrusions on the southwest side of Mount Hood, and the late Tertiary volcanic rocks they intrude, exhibit typical greenschist metamorphic minerals including epidote, quartz, chlorite, magnetite, pyrite, actinolite, prehnite, adularia, calcite, and wairakite. Hornblende quartz microdiorite sills and dikes(?) that intrude late Tertiary volcanic rocks on the northwest side of Mount Hood were penetrated by two drill holes; many of the low-grade metamorphic minerals recovered in drill-core and cuttings samples were the same as those observed in the Laurel Hill and Still Creek outcrop and drill-hole samples. Near Iron Creek, to the southeast of Mount Hood, the presence of another intrusive body is suggested by geophysical studies; one dike from this area has a K-Ar age of $\sim 5 \mathrm{Ma}$. The late Tertiary intruded volcanic rocks in the Iron Creek area contain a greenschist-facies metamorphic mineral assemblage similar to the assemblage at Laurel Hill and Still Creek. Lower
\end{abstract}

temperature, zeolite-facies minerals, consisting of various zeolite minerals, carbonate minerals, clay minerals, and hematite, are frequently superimposed upon the higher temperature, greenschist to subgreenschist mineral assemblages in the Mount Hood area. Late Tertiary zeolite-facies metamorphism occurs in several areas around Mount Hood and may be more widespread than observed in this investigation.

Mount Hood Quaternary lava flows contain only sparse hydrothermal mineralization. Intense acid-sulfate alteration, producing silica minerals, sulfur, sulfate minerals, pyrite, and iron oxides and hydroxide, occurs in a fumarolic area (temperature $\sim 91^{\circ} \mathrm{C}$ ) near the summit of the mountain. Quaternary volcaniclastic debris units on the lower slopes of the mountain often contain redeposited fumarolically altered material. Geothermal test drill holes on the outer flanks of Mount Hood encountered mostly lowtemperature $\left(<23^{\circ} \mathrm{C}\right)$ waters. Thermal water between about $60^{\circ}$ and $113^{\circ} \mathrm{C}$ was found in four drill holes, which suggests that very low-temperature zeolite-facies metamorphism might presently be occurring at depth in the Mount Hood area. If present metamorphism in the Mount Hood area is similar to the late Tertiary metamorphic conditions, it can be predicted that any active higher temperature metamorphism must take place at considerable depth within narrow halos surrounding solidified intrusions.

\section{INTRODUCTION}

Mount Hood, an active volcano in the Cascade Mountains of northern Oregon, was designated a "Known Geothermal Resource Area" (KGRA) under the Geothermal Steam Act of 1970 (Godwin and others, 1971). Mount Hood was thought to have good potential for geothermal energy because of its late Pleistocene to Holocene volcanic activity (as recent as 200 to 300 years ago) (Crandell, $1980)$, near-summit fumaroles, and the tepid $\left(<26^{\circ} \mathrm{C}\right)$ thermal springs near the base of the mountain on the south. Accordingly, a cooperative multidisciplinary geothermalresource-assessment program was begun in 1976 by the 
Oregon Department of Geology and Mineral Industries (DOGAMI), U.S. Department of Energy (DOE), U.S. Forest Service (USFS), and U.S. Geological Survey (USGS). A major part of the assessment program included drilling several shallow geothermal gradient holes and a few deeper exploration holes. During the 1976 to 1980 program period, 30 geothermal drill holes were completed in the vicinity of Mount Hood (fig. 1); 15 drill holes were spudded by DOGAMI, 7 by Northwest Natural Gas Company (NWNG), 1 by DOE (which also provided funding for several other drill holes), and 7 by the USGS (Hook, 1982; Robison and others, 1982).

Temperature and geothermal gradient data have been reported for all Mount Hood geothermal drill holes (Hull and others, 1978; Blackwell and Steele, 1979; Blackwell and others, 1981a, b, c; Robison and others, 1981, 1982; Steele and others, 1982). Steele and others (1982) summarized the available heat-flow data for most drill holes and concluded that the data do not suggest the presence of a significant-sized shallow magma chamber beneath Mount Hood. An $\sim 5-\mathrm{km}$-diameter intrusive body that narrows upward to $\sim 1 \mathrm{~km}$ near the base of Mount Hood is suggested by aeromagnetic and gravity data (Williams and Keith, 1982). Steele and others (1982) also indicated that, although the heat-flow data for the volcano reflect a very complex thermal system, heat-transfer data for much of the volcano cannot be adequately represented by the existing shallow drill-hole data.

This report describes the hydrothermal alteration of numerous outcrop samples collected in the vicinity of Mount Hood, as well as drill cuttings from 13 of the geothermal drill holes (table 1) for which we were able to obtain sample splits. Several drill holes were not included in the study because the drilling reports suggested only minor or no hydrothermal mineralogy or because the drill cuttings were not located. The mineralogy of two other geothermal drill holes, also not included in this study, have previously been described (Timberline 3, White, 1979, and Old Maid Flat 7A, Holdaway and Bussey, 1982).

This study is also an outgrowth of a geologic and mineral survey of the Mount Hood Wilderness area in compliance with the Wilderness Act (Public Law 88-577, Sept. 3, 1964), which requires that the U.S. Geological Survey and the U.S. Bureau of Mines evaluate the mineral resource potential of certain specified parcels of government-owned land. The Mount Hood Wilderness area comprises about 47,100 acres, which include the summit of the volcano and its north, east and west flanks (Keith, Beeson, and Bargar, 1982); in addition, much of Zigzag Mountain (fig. 1), to the west of Mount Hood, lies within the wilderness area.

\section{ANALYTICAL METHODS}

For most drill holes, drill cuttings were sampled at about 3-m intervals, with more closely spaced sample in- tervals in selected portions of a few drill holes; however, for the two earliest completed drill holes included in this report (table 1), samples were obtained at only about $12-\mathrm{m}$ intervals. Cuttings splits were wet sieved through a 200mesh screen; generally, both the coarse and fine fractions were air dried and saved. Cuttings from each of the drill holes were systematically examined by binocular microscope; gravel- to silt-size grains were hand picked for several types of analyses. Thin sections were made of representative grains from the various lava flows and of volcaniclastic intervals penetrated by several drill holes. Selected whole-rock and hydrothermal mineral samples were hand picked for X-ray diffraction (XRD) analyses using a Norelco unit and $\mathrm{Cu}-\mathrm{K} \alpha$ radiation. Rock and mineral samples were hand ground and prepared as slurries on glass slides. All samples were run at $1^{\circ} 2 \theta / \mathrm{min}$; selected samples were glycolated by placing the slides in an atmosphere of ethylene glycol at $60^{\circ} \mathrm{C}$ for 1 hour before $\mathrm{X}$ raying. Euhedral hydrothermal mineral samples were carbon coated and placed in either a Cambridge Stereoscan 180 or 250 scanning electron microscope (SEM) in order to obtain information on paragenesis, semiquantitative chemistry, and mineral morphology. Quantitative chemical analyses of several hydrothermal minerals from drill cuttings and outcrop samples were obtained by analysis of polished thin sections or mineral mounts using an ARLSEMQ electron microprobe. Double-polished thick sections of hydrothermal quartz from some drill cuttings and outcrop samples were prepared for fluid-inclusion studies using a Linkam THM 600 heating/freezing stage and TMS 90 controller.

Keith and others (1985) published K-Ar dates for 24 rock samples from near Mount Hood in order to clarify the ages of several volcanic units mapped by Wise (1969); major- and trace-element chemical analyses for several of these dated rocks and other rock samples from the Mount Hood area are given in table 2. Major-element chemical analyses are by $\mathrm{X}$-ray spectroscopy, and trace elements were analyzed by emission spectroscopy. Techniques for these two methods are as described in Baedecker (1987).

\section{ACKNOWLEDGMENTS}

We thank many of the past and present staff of the Oregon Department of Geology and Mineral Industries, particularly Donald A. Hull, Joseph F. Riccio, and George R. Priest, for allowing us to obtain splits of cuttings from several drill holes, for providing us with copies of drillers reports on all of the geothermal drill holes near Mount Hood, and for helpful discussions on the geology of the Mount Hood area. Scanning electron micrographs were provided by Robert L. Oscarson. James R. Boden, Michael L. Heard, Maura Hanning, and Joyce Miley assisted in some of the X-ray diffraction work. Reviews and constructive 
criticisms of the manuscript by Richard C. Erd and Robert I. Tilling are very much appreciated. We are especially grateful to John W. Hook for sharing his many geological insights on Mount Hood and the Oregon Cascades.

\section{GEOLOGIC SETTING}

Mount Hood, which lies in northern Oregon along the crest of the High Cascade Range, is a Quaternary stratovolcano that remains potentially active (Crandell, 1980). The summit (fig. 2), at an elevation of $3,425 \mathrm{~m}$, is snow covered much of the year and is very conspicuous above the surrounding volcanic terrain (average altitude of about $1,220 \mathrm{~m}$ ). Intermittent volcanic activity has occurred in this area since the middle Miocene (Wise, 1969; Beeson and Moran, 1979; Covert and Meyer, 1979; Beeson and others, 1982, 1985). Rocks of the Columbia River Basalt Group are overlain by late Miocene andesitic lava flows and volcaniclastic rocks of the Rhododendron Formation that crop out in the Zigzag Mountain area immediately west of Mount Hood (fig. 3). The Rhododendron Formation is intruded by late Miocene andesite plugs that probably fed the andesite lava flows overlying the Rhododendron Formation. Andesitic lava flows of similar age occur all around Mount Hood and probably were extruded from several different vents (Wise, 1969).

Roadcuts just south of Zigzag Mountain furnish excellent exposures of the Laurel Hill intrusion. This late Miocene quartz diorite intrusive body appears to be greater in extent than is indicated by surface outcrops (Wise, 1969); similar intrusive rocks have been found in drill holes as far as $2.2 \mathrm{~km}$ east and about $9.2 \mathrm{~km}$ north of the Laurel Hill outcrop (Gannett, 1982; Priest and others, 1982). Wise (1969) also suggested that the quartz diorite to quartz monzonite Laurel Hill and Still Creek intrusions (about $3 \mathrm{~km}$ to the south) might be related and are possibly coextensive beneath the surface. The Laurel Hill intrusion may have caused fractures and block faulting of older andesitic rocks on Zigzag Mountain.

Pliocene andesite flows cap Zigzag Mountain and overlie the late Miocene andesite flows on all sides of Mount Hood. Like the older andesite lava flows, these late Pliocene andesite lavas were probably extruded from several different vents in the area.

A glacially dissected Pliocene or Pleistocene (an age of 3.2 Ma was reported by Wise (1969), but Keith and others (1985) gave an age range of 1.14 to $1.35 \mathrm{Ma}$ ) volcano, known as the Sandy Glacier volcano (fig. 3), is exposed on the west slope of Mount Hood about $4 \mathrm{~km}$ from the summit. Outcrops of basalt and andesite flows of this well-developed volcanic cone dip east and southeast beneath Mount Hood (Wise, 1969). Geophysical studies by Flanagan and Williams (1982) suggested the presence of two other volcanic cones buried beneath the present Mount Hood volcano.
The present Mount Hood edifice is the product of volcanic activity over about the past $0.73 \mathrm{Ma}$, so inferred because no magnetically reversed rocks, older than the Brunhes-Matuyama polarity epoch boundary (Mankinen and Dalrymple, 1979), have yet been found (Priest, 1982). The accumulation of layer upon layer of andesitic lava flows and pyroclastic rocks built the volcano to its present height or perhaps somewhat higher (Crandell, 1980). According to Crandell's (1980) description of later stages of volcanic activity at Mount Hood, predominantly andesitic volcanism waned during the Fraser glaciation ( $29 \mathrm{ka})$, and subsequent volcanic activity was dominated by hornblende dacite pyroclastic deposits, mudflows, and dome extrusion. The four most recent major eruptive periods are known as the Polallie (12 to 15 ka), Timberline ( 1.4 to $1.8 \mathrm{ka}$ ), Zigzag (0.6 to $0.4 \mathrm{ka}$ ), and Old Maid ( 0.25 to $0.18 \mathrm{ka}$ ) eruptive periods (Crandell, 1980; Cameron and Pringle, 1986, 1987). Crandell (1980) reported that during the Old Maid period a dome, a remnant of which is now known as Crater Rock, was formed just south of the summit of Mount Hood. Volcanic ejecta may have been deposited during mild activity reported in the mid-1800's (Crandell, 1980; Cameron and Pringle, 1986, 1987). Historical activity and present-day fumaroles near Crater Rock (fig. 3) indicate that Mount Hood is still active.

\section{STRATIGRAPHY}

\section{COLUMBIA RIVER BASALT GROUP}

The oldest rocks encountered in the drill cuttings we studied (Old Maid Flat 1 and Clear Fork drill holes; table 1 , Nos. 5 and 6) have been correlated with the $\sim 13.5$ - to 16-Ma (McKee and others, 1977) tholeiitic Grande Ronde and Wanapum Basalts of the Yakima Basalt Subgroup of the Columbia River Basalt Group (Covert and Meyer, 1979; Priest and others, 1982). Wise (1969) briefly described the petrology and major-element chemistry of the Columbia River Basalt Group near Mount Hood. Additional information on structure, stratigraphy, trace-element geochemistry, and geologic history of the Columbia River Basalt Group in the vicinity of Mount Hood can be found in Beeson and Moran (1979), Wollenberg and others (1979), and Beeson and others $(1982,1985)$. Priest and others' (1982) evaluation of the geothermal energy potential of the Mount Hood area indicated that the rocks of the Columbia River Basalt Group recovered from the Old Maid Flat (OMF) geothermal drill holes 1 (table 1) and $7 \mathrm{~A}$ are largely unaltered and have open fractures. They concluded that the brittle, faulted (highly permeable) rocks of the Columbia River Basalt Group in the vicinity of Mount Hood might be a worthwhile reservoir for future geothermal exploration. 


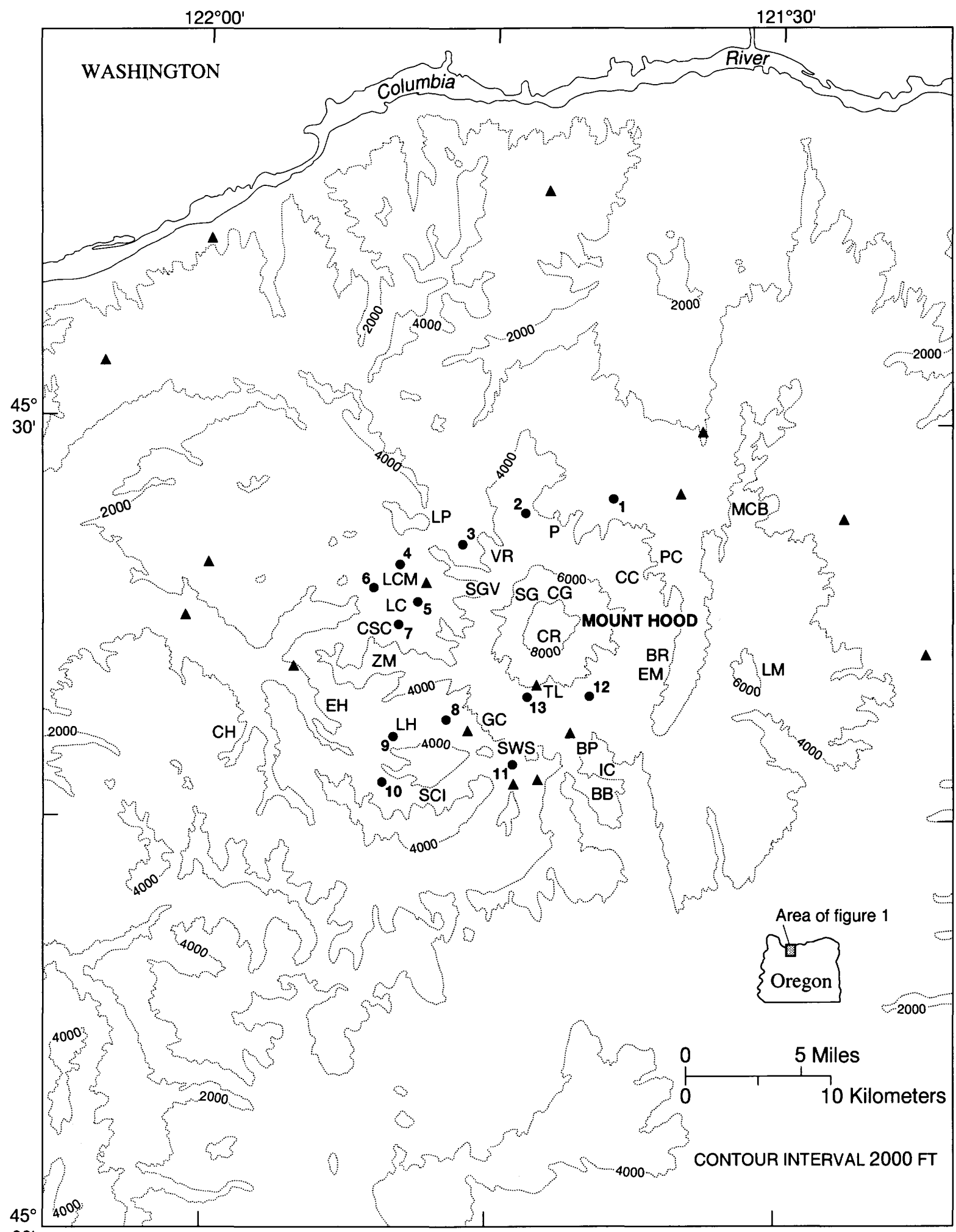

$00^{\prime}$

Figure 1. Topographic map of Mount Hood area showing the location of geothermal drill holes (dots) included in this report (numbered 1-13; see table 1) and other geothermal gradient drill holes (triangles) in the vicinity of Mount Hood. Abbreviations for names of topographic features referred to in the text of this report are BB, Barlow Butte; BP, Barlow Pass-Bennett Pass area; BR, Bluegrass Ridge; CSC, Cast Creek-Short Creek area; CH, Cheeney Creek; CC, Cloud Cap; CG, Coe Glacier; CR, Crater Rock; EH, Enola Hill; EM, Elk Meadows; GC, Government Camp; IC, Iron Creek; LCM, Last Chance Mountain; LH, Laurel Hill; LP, Lolo Pass; LM, Lookout Mountain, LC, Lost Creek; MCB, Mill Creek Buttes; P, The Pinnacle; PC, Polallie Creek; SCI, Still Creek intrusion; SG, Sandy Glacier; SGV, Sandy Glacier volcano; SWS, Swim Warm Springs; TL, Timberline Lodge; VR, Vista Ridge; and ZM, Zigzag Mountain. Base is modified from U.S. Geological Survey map of The Dalles, Oregon-Washington, 1971, 1:250,000. 
Table 1. Geothermal drill holes near Mount Hood selected for hydrothermal mineralization studies.

[Data from Robison and others (1982). Abbreviation of drilling organization: DOGAMI, Oregon Department of Geology and Mineral Industries; NWNG, Northwest Natural Gas; USGS, U.S. Geological Survey]

\begin{tabular}{|c|c|c|c|c|c|c|c|c|c|}
\hline $\begin{array}{l}\text { Map } \\
\text { No. }{ }^{1}\end{array}$ & Name of drill site ${ }^{2}$ & Location $^{3}$ & Latitude & Longitude & $\begin{array}{l}\text { Year } \\
\text { drilled }\end{array}$ & $\begin{array}{l}\text { Drilling } \\
\text { organi- } \\
\text { zation }\end{array}$ & $\begin{array}{l}\text { Drill-collar } \\
\text { altitude (m } \\
\text { above m.s.l.) }\end{array}$ & $\begin{array}{l}\text { Total } \\
\text { depth } \\
(\mathrm{m})\end{array}$ & $\begin{array}{l}\text { Max } \\
\text { temp } \\
\left({ }^{\circ} \mathrm{C}\right) \\
\end{array}$ \\
\hline 1 & Eliot Branch & $1 \mathrm{~S} / 9 \mathrm{E} / 26 \mathrm{aba}$ & $45^{\circ} 27.6^{\prime}$ & $121^{\circ} 38.0^{\prime}$ & 1980 & USGS & 860 & 220 & 10.3 \\
\hline 2 & Clear Branch & $1 \mathrm{~S} / 9 \mathrm{E} / 31 \mathrm{aca}$ & $45^{\circ} 26.5^{\prime}$ & $121^{\circ} 43.0^{\prime}$ & 1980 & USGS & 1,250 & 311 & 10.9 \\
\hline 3 & McGee Creek & $2 \mathrm{~S} / 8 \mathrm{E} / \mathrm{lccd}$ & $45^{\circ} 25.1^{\prime}$ & $121^{\circ} 46.1^{\prime}$ & 1979,1980 & USGS & 915 & 610 & 60.0 \\
\hline 4 & Last Chance Mountain & $2 \mathrm{~S} / 8 \mathrm{E} / 9 \mathrm{dba}$ & $45^{\circ} 24.5^{\prime}$ & $121^{\circ} 49.5^{\prime}$ & 1979 & NWNG & 890 & 152 & 13.1 \\
\hline 5 & Old Maid Flat (OMF-1) & $2 \mathrm{~S} / 8 \mathrm{E} / 15 \mathrm{cda}$ & $45^{\circ} 23.5^{\prime}$ & $121^{\circ} 48.5^{\prime}$ & 1977,1978 & NWNG & 838 & 1,220 & 82 \\
\hline 6 & Clear Fork (OMF-3) & $2 \mathrm{~S} / 8 \mathrm{E} / 17 \mathrm{cbd}$ & $45^{\circ} 23.3^{\prime}$ & $121^{\circ} 51.6^{\prime}$ & 1978 & NWNG & 658 & 402 & 23.2 \\
\hline 7 & Lost Creek (OMF-10) & $2 \mathrm{~S} / 8 \mathrm{E} / 28 \mathrm{aab}$ & $45^{\circ} 22.4^{\prime}$ & $121^{\circ} 49.3^{\prime}$ & 1979 & NWNG & 811 & 131 & 10.8 \\
\hline 8 & Zigzag River (Kiwanis Camp Road) & $3 \mathrm{~S} / 8 \mathrm{E} / 14 \mathrm{bcb}$ & $45^{\circ} 18.9^{\prime}$ & $121^{\circ} 47.7^{\prime}$ & 1979 & NWNG & 951 & 287 & 12 \\
\hline 9 & Laurel Hill & $3 \mathrm{~S} / 8 \mathrm{E} / 16 \mathrm{~cd}$ & $45^{\circ} 18.4^{\prime}$ & $121^{\circ} 49.9^{\prime}$ & 1976 & DOGAMI & 762 & 125 & 10.2 \\
\hline 10 & Still Creek & $3 \mathrm{~S} / 8 \mathrm{E} / 29 \mathrm{ddc}$ & $45^{\circ} 16.6^{\prime}$ & $121^{\circ} 54.5^{\prime}$ & 1978 & DOGAMI & 722 & 152 & 17.6 \\
\hline 11 & Snow Bunny & $3 \mathrm{~S} / 8.5 \mathrm{E} / 25 \mathrm{aac}$ & $45^{\circ} 17.2^{\prime}$ & $121^{\circ} 43.7^{\prime}$ & 1976 & DOGAMI & 1,168 & 82.5 & 7.2 \\
\hline 12 & Mount Hood Meadows & $3 \mathrm{~S} / 9 \mathrm{E} / 3 \mathrm{cca}$ & $45^{\circ} 20.0^{\prime}$ & $121^{\circ} 39.6^{\prime}$ & 1980 & USGS & 1,665 & 355 & 11.6 \\
\hline 13 & Pucci Chairlift & $3 \mathrm{~S} / 9 \mathrm{E} / 7 \mathrm{dbb}$ & $45^{\circ} 19.3^{\prime}$ & $121^{\circ} 42.8^{\prime}$ & 1979,1980 & USGS & 1,628 & 1,220 & 65.5 \\
\hline
\end{tabular}

${ }^{1}$ Numbers refer to drill holes on figure 1.

${ }^{2}$ Names in parentheses are alternate drill-hole designations.

${ }^{3}$ Locations are given as township/range/section. Section letters a, b, c, and d refer to NE, NW, SW, and SE quarter sections, respectively in the sequence $1 / 4,1 / 41 / 4$, and 1/4 1/4 1/4. For example: in 26aba, 26 is the section number, first $a=N E 1 / 4$ section, $b=N W 1 / 4$ of NE1/4 section, and second $\mathrm{a}=\mathrm{NE} 1 / 4$ of NW $1 / 4$ of NE1/4 section.

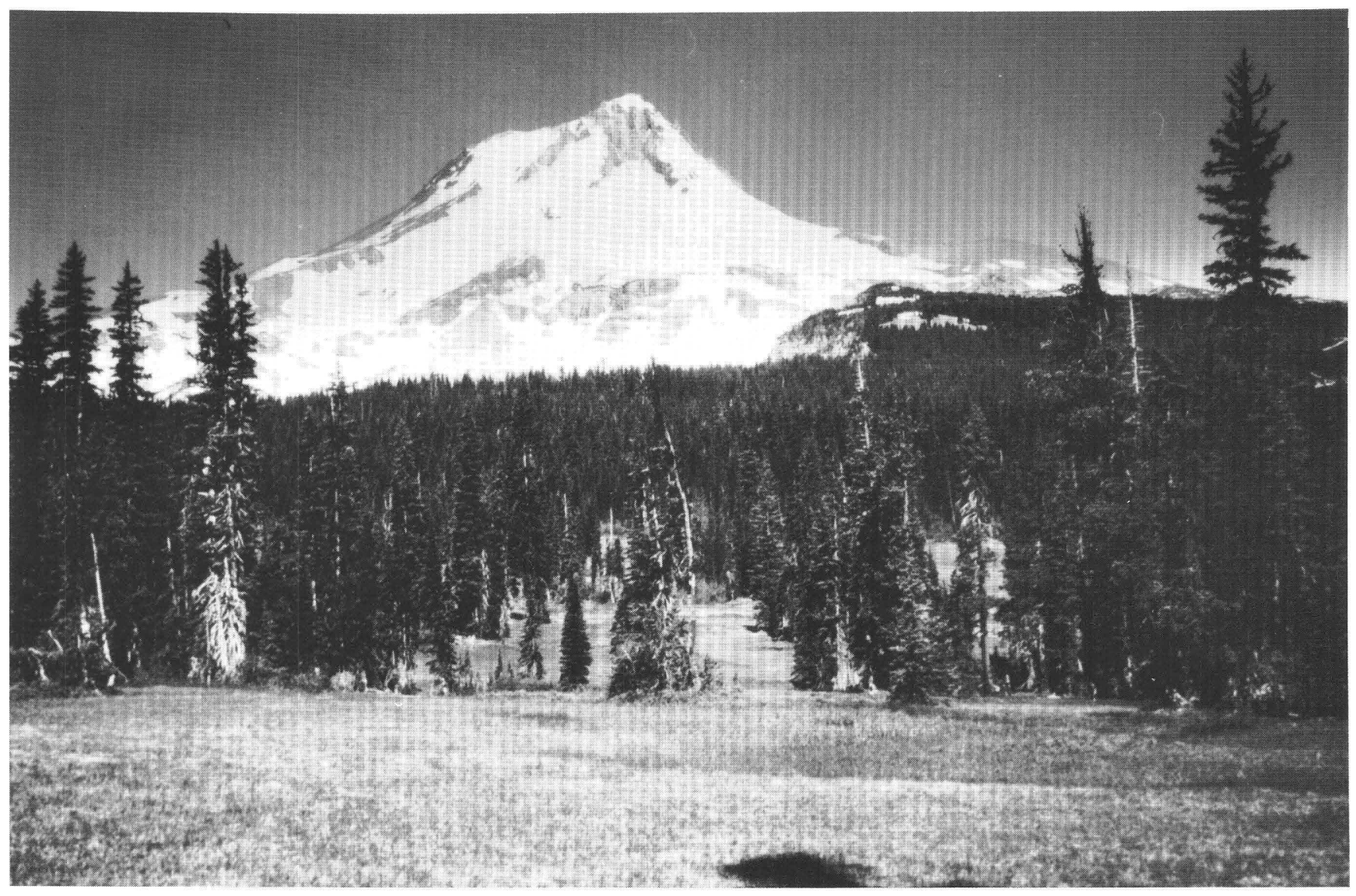

Figure 2. View of Mount Hood from Elk Meadows, about $7 \mathrm{~km}$ east-southeast of the summit. 


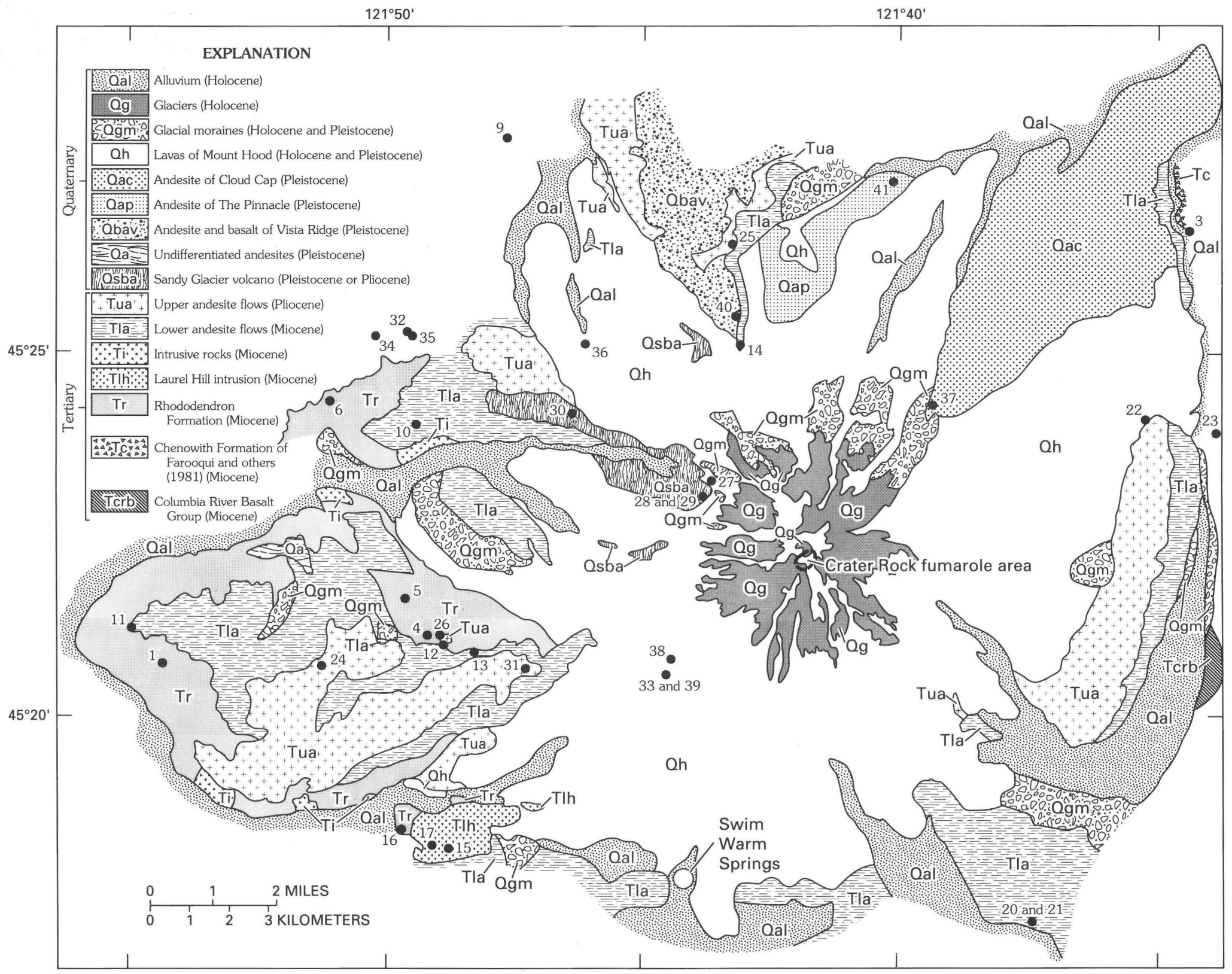

Figure 3. Geologic map of the Mount Hood area, Oregon (modified from Wise, 1969; Keith, Beeson, and Bargar, 1982). Numbers (1-41) are the locations of chemically analyzed rocks of table 2 , except for rocks numbered $2,7,8,18$, and 19 , which were collected outside the map area. 
Columbia River Basalt Group drill cuttings from the OMF-1 and Clear Fork drill holes (table 1, Nos. 5 and 6) contained moderate amounts of hydrothermal minerals including quartz, chalcedony, laumontite, stilbite, smectite, chlorite, siderite, calcite, hematite, and a $10-\AA$ mica group mineral. A highly fractured outcrop on the east side of Mount Hood (Tcrb, right-hand side, fig. 3), mapped as the Columbia River Basalt Group by Wise (1969), was considerably altered and contained abundant disseminated pyrite; fracture fillings of chlorite, magnetite, hematite, pyrite, quartz, chalcedony, and calcite; and chlorite groundmass alteration. This outcrop is very close to the Hood River Fault (Priest, 1982), which probably caused outcrop fracturing as well as provided a pathway for movement of mineral-depositing solutions. The permeability of outcrop and drill-cuttings samples of the Columbia River Basalt Group that we examined was significantly reduced by deposition of hydrothermal minerals.

\section{RHODODENDRON FORMATION}

Three drill holes (Last Chance Mountain, OMF-1, and Clear Fork; table 1, Nos. 4, 5, and 6) penetrated rocks that are correlated with the late Miocene Rhododendron Formation (Covert and Meyer, 1979; Priest and others, 1982; Trimble, 1963). In the Mount Hood area, this formation consists of as much as $600 \mathrm{~m}$ of predominantly andesitic, epiclastic, laharic deposits, pyroclastic tuffs, and lava flows (Gannett, 1982). According to Wise (1969) and Gannett (1982), the volcaniclastic deposits and lava flows of the Rhododendron Formation consist mostly of pyroxene (both hypersthene and augite) andesites and sporadic minor hornblende andesites. However, major-element chemical analyses of outcrop samples (Wise, 1969; Gannett, 1982) and drill-hole material from OMF-1 and OMF-7A (Priest and Vogt, 1982) also show the presence of several dacites. Trace-element data permitted Gannett (1982) to distinguish Rhododendron lava flows and breccia clasts from compositionally similar overlying late Miocene (designated as early Pliocene in age by Wise, 1969) volcanic rocks. Wise (1969) reported a K-Ar date of $7 \mathrm{Ma}$, which Gannett (1982) suggested may be too young, for a lava clast in the lower part of the Rhododendron Formation. Priest and others (1982) obtained K-Ar ages of 9.5, 10.6, and 12.1 Ma for altered whole-rock samples from the upper part of the Rhododendron Formation. Similar average $\mathrm{K}$-Ar ages of 10.53 and $11.23 \mathrm{Ma}$ were reported by Keith and others (1985) for andesitic lava flows (table 2, analyses 1 and 2) in the upper part of the formation. Thus, rocks of the Rhododendron Formation were probably extruded during about a 3- to 4-m.y. interval in the late Miocene (Gannett, 1982; Trimble, 1963).

Virtually all outcrop and geothermal exploration drillhole samples that contain materials of the Rhododendron
Formation exhibit extensive low-temperature hydrothermal alteration. In addition, Rhododendron tuffs and lava flows adjacent to intrusive bodies have been contact metamorphosed, propylitically altered, or have undergone minor epithermal mineralization. The most abundant hydrothermal minerals found in the Rhododendron Formation are laumontite and stilbite (less abundant zeolites include epistilbite, heulandite, harmotome, mordenite, scolecite, stellerite(?), and wairakite), smectite (less abundant clay minerals are illite, mixed-layer illite-smectite, chlorite, mixed-layer chlorite-smectite, celadonite, kaolinite-serpentine, and sepiolite), calcite (less abundant carbonates include siderite, ankerite, dolomite, cerussite, and manganoan calcite), sulfides (pyrite, chalcopyrite, galena, and sphalerite), silica minerals (quartz, chalcedony, and minor B-cristobalite), and iron oxides (hematite and magnetite); epidote, actinolite, adularia, chrysocolla, and anglesite also are present.

On the east side of Mount Hood, the Dalles Formation (equivalent to the Chenoweth Formation of Farooqui and others, 1981) contains rocks lithologically similar to the Rhododendron Formation and is generally regarded to be, at least in part, contemporaneous with the Rhododendron Formation (Wise, 1969; Gannett, 1982). This correlation was based, in part, on a K-Ar age of 7.0 Ma for a lava flow that overlies the Dalles Formation (Wise, 1969). Keith and others (1985) obtained a K-Ar age of $8.18 \mathrm{Ma}$ for a hornblende-pyroxene andesite flow (table 2, analysis 3 ), which is probably one of two interbedded andesite flows noted by Wise (1969) near the top of the formation.

\section{LATE MIOCENE ANDESITIC LAVA FLOWS AND INTRUSIVE PLUGS}

Pyroxene andesite lava flows that overlie the Rhododendron and Chenoweth Formations have $\mathrm{K}$-Ar ages of 5.5 Ma on Zigzag Mountain, 5.8 Ma near Lolo Pass on the west side of Mount Hood, and 7.0 Ma near Polallie Creek on the east side of Mount Hood (Wise, 1969). According to chemical and petrographic analyses by Wise (1969), these late Miocene volcanic rocks are mostly two-pyroxene andesites with some olivine andesites and basalts.

Priest and others (1982) subdivided the late Miocene andesites at Last Chance Mountain near the OMF-1 and OMF-7A drill holes and informally called the lower, coarse-grained two-pyroxene andesitic unit the Last Chance andesite. Major-oxide and trace-element chemical analyses for three of the andesitic rocks encountered in the OMF-7A drill hole were given in Priest and Vogt (1982); Priest and others (1982) reported K-Ar ages of 10.5 and 10.7 Ma for the Last Chance andesite. Keith and others (1985) reported whole-rock K-Ar ages of about 5.4, 6.2, and 8.9 Ma for lava flows that overlie the Rhododendron Formation at Vista Ridge (northwest of Mount Hood), 


\begin{tabular}{|c|c|c|c|c|c|c|c|c|c|}
\hline \multirow[b]{2}{*}{ Analysis number } & \multicolumn{2}{|c|}{ Rhododendron Formation } & \multirow{2}{*}{$\begin{array}{c}\text { Chenoweth } \\
\text { Formation } \\
3 \\
\end{array}$} & \multicolumn{6}{|c|}{ Late Miocene lava flows and intrusive plugs } \\
\hline & 1 & 2 & & 4 & 5 & 6 & 7 & 8 & 9 \\
\hline Sample number & $81 \mathrm{MH}-14$ & $81 \mathrm{MH}-21$ & 79 EF-0016A & 79 ZZL-1089 & 79 CCT-1094 & 79 LP-1 108 & $79 \mathrm{KL}-1117$ & $79 \mathrm{KL}-1120 \mathrm{~A}$ & $79 \mathrm{LL}-1126 \mathrm{C}$ \\
\hline \multicolumn{10}{|c|}{ Major-element chemical analyses (wt percent oxides) ${ }^{1}$} \\
\hline 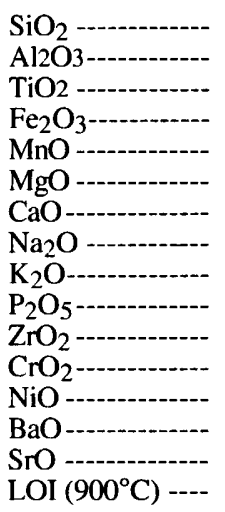 & $\begin{array}{l}59.8 \\
16.8 \\
0.80 \\
6.15 \\
0.09 \\
3.1 \\
5.94 \\
3.8 \\
1.00 \\
0.18 \\
0.014 \\
0.007 \\
0.003 \\
0.034 \\
0.040 \\
1.75 \\
\end{array}$ & $\begin{array}{l}54.8 \\
19.5 \\
0.94 \\
7.02 \\
0.10 \\
2.5 \\
7.60 \\
4.1 \\
0.98 \\
0.20 \\
0.014 \\
0.002 \\
<0.002 \\
0.025 \\
0.052 \\
2.00 \\
\end{array}$ & $\begin{array}{l}63.2 \\
17.2 \\
0.69 \\
5.49 \\
0.08 \\
2.34 \\
5.29 \\
4.02 \\
1.41 \\
0.15 \\
0.02 \\
0.01 \\
0.003 \\
0.035 \\
0.055 \\
0.65 \\
\end{array}$ & $\begin{array}{c}51.2 \\
17.3 \\
1.10 \\
9.42 \\
0.16 \\
7.36 \\
10.6 \\
2.84 \\
0.28 \\
0.14 \\
0.01 \\
0.03 \\
0.009 \\
0.014 \\
0.047 \\
0.12 \\
\end{array}$ & $\begin{array}{l}56.9 \\
18.6 \\
0.94 \\
6.30 \\
0.09 \\
3.82 \\
6.55 \\
3.82 \\
0.18 \\
0.21 \\
0.03 \\
0.02 \\
0.008 \\
0.02 \\
0.07 \\
2.81 \\
\end{array}$ & $\begin{array}{c}64.4 \\
17.1 \\
0.57 \\
4.66 \\
0.08 \\
1.74 \\
4.38 \\
4.19 \\
1.32 \\
0.19 \\
0.03 \\
<0.005 \\
0.002 \\
0.038 \\
0.064 \\
1.63 \\
\end{array}$ & $\begin{array}{l}58.7 \\
16.5 \\
0.95 \\
6.75 \\
0.14 \\
4.83 \\
6.41 \\
3.20 \\
0.61 \\
0.17 \\
0.02 \\
0.02 \\
0.01 \\
0.028 \\
0.048 \\
2.24 \\
\end{array}$ & $\begin{array}{l}53.3 \\
18.2 \\
1.44 \\
8.63 \\
0.13 \\
4.88 \\
8.77 \\
3.50 \\
0.80 \\
0.30 \\
0.02 \\
0.01 \\
0.004 \\
0.032 \\
0.097 \\
0.84 \\
\end{array}$ & $\begin{array}{l}60.1 \\
17.4 \\
0.84 \\
6.43 \\
0.10 \\
3.30 \\
6.13 \\
3.86 \\
1.29 \\
0.16 \\
0.02 \\
0.01 \\
0.005 \\
0.037 \\
0.05 \\
1.02 \\
\end{array}$ \\
\hline Total---------- & 99.51 & 99.84 & 100.64 & 100.63 & 100.37 & 100.39 & 100.63 & 100.95 & 100.75 \\
\hline \multicolumn{10}{|c|}{ Trace-element chemical analyses (ppm) ${ }^{2}$} \\
\hline 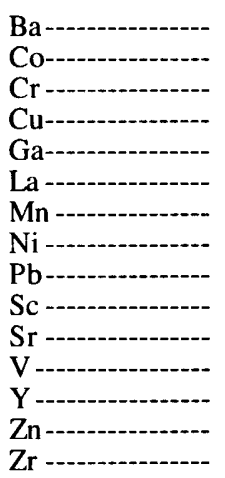 & $\begin{array}{r}350 \\
19 \\
65 \\
51 \\
22 \\
<10 \\
690 \\
22 \\
<10 \\
15 \\
410 \\
120 \\
23 \\
74 * \\
144^{*}\end{array}$ & $\begin{array}{r}220 \\
19 \\
19 \\
52 \\
23 \\
<10 \\
730 \\
14 \\
<10 \\
15 \\
520 \\
120 \\
24 \\
58^{*} \\
140^{*}\end{array}$ & $\begin{array}{r}320 \\
13 \\
34 \\
23 \\
17 \\
<20 \\
650 \\
22 \\
11 \\
11 \\
390 \\
69 \\
14 \\
57 \\
190\end{array}$ & $\begin{array}{r}91 \\
38 \\
240 \\
98 \\
13 \\
<20 \\
1000 \\
81 \\
18 \\
42 \\
250 \\
220 \\
28 \\
96 \\
140\end{array}$ & $\begin{array}{r}140 \\
18 \\
150 \\
28 \\
18 \\
<20 \\
630 \\
60 \\
12 \\
21 \\
370 \\
170 \\
21 \\
80 \\
250\end{array}$ & $\begin{array}{c}340 \\
9.0 \\
18 \\
36 \\
20 \\
<20 \\
630 \\
13 \\
11 \\
<10 \\
430 \\
38 \\
10 \\
72 \\
200\end{array}$ & $\begin{array}{r}200 \\
21 \\
150 \\
22 \\
14 \\
<20 \\
980 \\
68 \\
14 \\
20 \\
290 \\
150 \\
22 \\
63 \\
260\end{array}$ & $\begin{array}{r}230 \\
27 \\
39 \\
53 \\
18 \\
<20 \\
920 \\
34 \\
14 \\
26 \\
620 \\
190 \\
24 \\
96 \\
200\end{array}$ & $\begin{array}{r}250 \\
18 \\
43 \\
170 \\
16 \\
<20 \\
770 \\
31 \\
<10 \\
18 \\
320 \\
120 \\
21 \\
75 \\
240\end{array}$ \\
\hline $\mathrm{K}-\mathrm{Ar}$ date $(\mathrm{Ma})^{3}-$ & $\begin{array}{l}10.52 \pm 0.12 \\
10.54 \pm 0.11\end{array}$ & $\begin{array}{l}11.15 \pm 0.12 \\
11.32 \pm 0.12\end{array}$ & $8.18 \pm 0.06$ & $\begin{array}{l}6.09 \pm 0.29 \\
6.25 \pm 0.39\end{array}$ & & $\begin{array}{l}6.31 \pm 0.12 \\
6.11 \pm 0.22\end{array}$ & & & \\
\hline
\end{tabular}

${ }^{1}$ Major-element chemical analyses are by X-ray spectroscopy. Analyses were made at various times and by various analysts: J.S. Wahlberg, J. Taggart, J. Baker,

L. Espos, J. Kent, and M. Dyslin.
2Trace-element chemical analyses are by emission spectroscopy; values denoted by "*" are Kevex 0700 determinations. Analyst: T. Fries.
3From Keith and others (1985). 


\begin{tabular}{|c|c|c|c|c|c|c|c|c|c|}
\hline \multirow[b]{2}{*}{ Analysis number } & \multicolumn{5}{|c|}{ Late Miocene lava flows and intrusive plugs } & \multicolumn{3}{|c|}{ Laurel Hill intrusion } & \multirow{2}{*}{$\begin{array}{c}\begin{array}{l}\text { Still Creek } \\
\text { intrusion }\end{array} \\
18 \\
\end{array}$} \\
\hline & 10 & 11 & 12 & 13 & 14 & 15 & 16 & 17 & \\
\hline Sample number & $80 \mathrm{CF}-0022 \mathrm{~A}$ & $80 \mathrm{ZM}-1013$ & $80 \mathrm{ZM}-1023 \mathrm{~A}$ & $80 \mathrm{ZM}-1030$ & $82 \mathrm{MH}-1$ & 79 LH-1058A & 80 LH-1058 & 80 LH-1035 & $78 \mathrm{SC}-5$ \\
\hline \multicolumn{10}{|c|}{ Major-element chemical analyses (wt percent oxides) ${ }^{1}$} \\
\hline 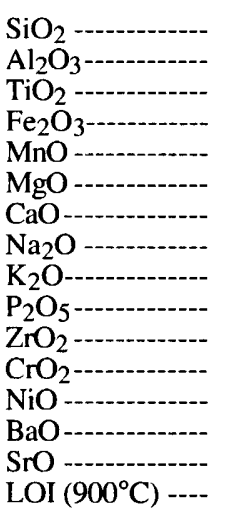 & $\begin{array}{l}58.0 \\
17.0 \\
0.93 \\
6.74 \\
0.08 \\
4.55 \\
6.76 \\
3.64 \\
1.14 \\
0.17 \\
0.03 \\
0.02 \\
0.007 \\
0.02 \\
0.05 \\
1.71 \\
\end{array}$ & $\begin{array}{l}59.6 \\
17.4 \\
0.76 \\
6.26 \\
0.10 \\
3.76 \\
6.53 \\
3.77 \\
1.13 \\
0.15 \\
0.02 \\
0.01 \\
0.005 \\
0.03 \\
0.05 \\
0.75 \\
\end{array}$ & $\begin{array}{l}58.6 \\
17.0 \\
0.95 \\
6.59 \\
0.13 \\
4.10 \\
6.70 \\
3.31 \\
1.30 \\
0.17 \\
0.02 \\
0.01 \\
0.008 \\
0.02 \\
0.05 \\
1.45 \\
\end{array}$ & $\begin{array}{l}55.6 \\
16.2 \\
0.93 \\
6.57 \\
0.10 \\
4.26 \\
5.64 \\
3.22 \\
1.97 \\
0.17 \\
0.02 \\
0.02 \\
0.007 \\
0.05 \\
0.05 \\
5.33 \\
\end{array}$ & $\begin{array}{l}55.9 \\
19.1 \\
1.12 \\
7.54 \\
0.11 \\
3.3 \\
7.06 \\
4.2 \\
0.50 \\
0.24 \\
0.01 \\
0.00 \\
0.002 \\
0.02 \\
0.07 \\
0.05 \\
\end{array}$ & $\begin{array}{l}55.7 \\
17.9 \\
1.09 \\
7.49 \\
0.15 \\
4.59 \\
7.74 \\
3.83 \\
0.65 \\
0.21 \\
0.01 \\
0.01 \\
0.006 \\
0.021 \\
0.057 \\
0.99 \\
\end{array}$ & $\begin{array}{l}63.4 \\
16.9 \\
0.66 \\
3.42 \\
0.04 \\
2.51 \\
4.45 \\
5.34 \\
0.93 \\
0.014 \\
0.02 \\
0.01 \\
0.005 \\
0.03 \\
0.06 \\
2.14 \\
\end{array}$ & $\begin{array}{l}60.8 \\
16.4 \\
0.89 \\
6.15 \\
0.09 \\
3.20 \\
5.69 \\
4.35 \\
1.60 \\
0.17 \\
0.04 \\
0.01 \\
0.005 \\
0.03 \\
0.04 \\
0.61 \\
\end{array}$ & $\begin{array}{l}58.8 \\
15.7 \\
0.86 \\
7.02 \\
0.04 \\
4.02 \\
6.17 \\
3.42 \\
1.64 \\
0.15 \\
0.03 \\
0.04 \\
0.016 \\
0.033 \\
0.049 \\
0.01 \\
\end{array}$ \\
\hline Total -............ & 100.85 & 100.33 & 100.41 & 100.14 & 99.22 & 100.44 & 99.93 & 100.08 & 98.00 \\
\hline \multicolumn{10}{|c|}{ Trace-element chemical analyses $(\mathrm{ppm})^{2}$} \\
\hline 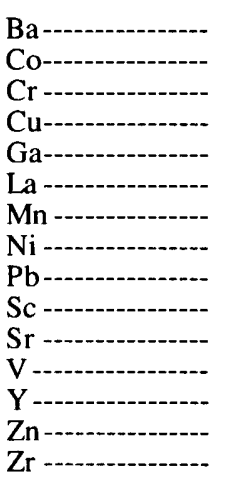 & $\begin{array}{r}210 \\
19 \\
130 \\
69 \\
16 \\
<20 \\
650 \\
60 \\
<10 \\
19 \\
330 \\
130 \\
18 \\
74 \\
220\end{array}$ & $\begin{array}{r}250 \\
19 \\
75 \\
67 \\
15 \\
<20 \\
780 \\
37 \\
17 \\
18 \\
330 \\
130 \\
20 \\
77 \\
190\end{array}$ & $\begin{array}{r}210 \\
22 \\
94 \\
21 \\
14 \\
<20 \\
920 \\
52 \\
15 \\
20 \\
310 \\
150 \\
22 \\
63 \\
220\end{array}$ & $\begin{array}{r}430 \\
16 \\
79 \\
34 \\
14 \\
<20 \\
670 \\
43 \\
15 \\
17 \\
310 \\
120 \\
21 \\
66 \\
220\end{array}$ & $\begin{array}{r}190 \\
21 \\
36 \\
51 \\
22 \\
<10 \\
820 \\
18 \\
<10 \\
15 \\
670 \\
120 \\
21 \\
82^{*} \\
126^{*}\end{array}$ & $\begin{array}{r}170 \\
19 \\
72 \\
34 \\
17 \\
<20 \\
970 \\
49 \\
<10 \\
20 \\
390 \\
150 \\
15 \\
56 \\
120\end{array}$ & $\begin{array}{r}270 \\
10 \\
31 \\
52 \\
15 \\
<20 \\
370 \\
20 \\
17 \\
<10 \\
360 \\
60 \\
17 \\
60 \\
160\end{array}$ & $\begin{array}{r}310 \\
16 \\
78 \\
75 \\
16 \\
<20 \\
690 \\
37 \\
16 \\
16 \\
320 \\
120 \\
23 \\
<50 \\
250\end{array}$ & $\begin{array}{r}310 \\
17 \\
84 \\
89 \\
16 \\
<20 \\
420 \\
44 \\
<10 \\
19 \\
340 \\
120 \\
21 \\
<50 \\
260\end{array}$ \\
\hline $\mathrm{K}-\mathrm{Ar}$ date $(\mathrm{Ma})^{3}-$ & $\begin{array}{l}7.65 \pm 0.10 \\
8.66 \pm 0.09 \\
9.63 \pm 0.07 \\
9.64 \pm 0.11 \\
\end{array}$ & & & & $5.44 \pm 019$ & $\begin{array}{l}8.60 \pm 0.14 \\
8.75 \pm 0.18\end{array}$ & & & \\
\hline
\end{tabular}




\begin{tabular}{|c|c|c|c|c|c|c|c|c|c|}
\hline \multirow[b]{2}{*}{ Analysis number } & \multirow{2}{*}{$\begin{array}{c}\begin{array}{l}\text { Still Creek } \\
\text { intrusion }\end{array} \\
19 \\
\end{array}$} & \multicolumn{2}{|c|}{$\begin{array}{l}\text { Late Miocene to } \\
\text { early Pliocene dike }\end{array}$} & \multicolumn{5}{|c|}{ Pliocene lava flows } & \multirow{2}{*}{$\begin{array}{c}\begin{array}{l}\text { Quaternary } \\
\text { lava flow }\end{array} \\
27 \\
\end{array}$} \\
\hline & & 20 & 21 & 22 & 23 & 24 & 25 & 26 & \\
\hline Sample number & 80 SC- 1032 & 79 IC-2039A & $79 \mathrm{MH}-2039 \mathrm{~A}$ & 79 TF-0004 & 79-SWC-0010A & $79 \mathrm{ZM}-0086$ & 79 RH-1032 & 79 ZZL-1085 & 79 SGV-1085 \\
\hline \multicolumn{10}{|c|}{ Major-element chemical analyses (wt percent oxides) $^{1}$} \\
\hline Total---------- & 101.13 & 100.23 & 100.67 & 100.32 & 100.39 & 100.86 & 100.73 & 100.92 & 100.37 \\
\hline \multicolumn{10}{|c|}{ Trace-element chemical analyses $(\mathrm{ppm})^{2}$} \\
\hline 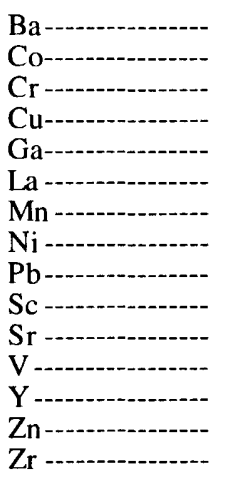 & $\begin{array}{r}360 \\
15 \\
73 \\
30 \\
15 \\
<20 \\
530 \\
35 \\
<10 \\
18 \\
290 \\
140 \\
30 \\
<50 \\
350\end{array}$ & $\begin{array}{r}410 \\
16 \\
37 \\
46 \\
16 \\
<20 \\
760 \\
31 \\
92 \\
16 \\
570 \\
110 \\
23 \\
64 \\
260\end{array}$ & $\begin{array}{r}360 \\
17 \\
36 \\
42 \\
16 \\
<20 \\
750 \\
33 \\
12 \\
16 \\
470 \\
110 \\
24 \\
84 \\
290\end{array}$ & $\begin{array}{r}320 \\
19 \\
41 \\
52 \\
15 \\
<20 \\
750 \\
35 \\
19 \\
16 \\
490 \\
110 \\
21 \\
76 \\
250\end{array}$ & $\begin{array}{r}360 \\
13 \\
14 \\
26 \\
16 \\
<20 \\
670 \\
11 \\
12 \\
12 \\
580 \\
92 \\
19 \\
61 \\
240\end{array}$ & $\begin{array}{r}370 \\
34 \\
110 \\
51 \\
16 \\
25 \\
940 \\
92 \\
13 \\
22 \\
700 \\
170 \\
24 \\
85 \\
260\end{array}$ & $\begin{array}{r}240 \\
24 \\
92 \\
77 \\
20 \\
<20 \\
850 \\
61 \\
16 \\
20 \\
600 \\
150 \\
17 \\
92 \\
190\end{array}$ & $\begin{array}{r}160 \\
38 \\
130 \\
65 \\
16 \\
<20 \\
960 \\
74 \\
17 \\
28 \\
410 \\
200 \\
22 \\
100 \\
190\end{array}$ & $\begin{array}{r}320 \\
13 \\
17 \\
23 \\
20 \\
<20 \\
650 \\
17 \\
16 \\
<10 \\
560 \\
72 \\
14 \\
57 \\
190\end{array}$ \\
\hline $\mathrm{K}$-Ar date $(\mathrm{Ma})^{3}-$ & & $5.26 \pm 0.44$ & & $\begin{array}{l}1.68 \pm 0.06 \\
1.88 \pm 0.05\end{array}$ & $2.7 \pm 0.03$ & $\begin{array}{l}2.24 \pm 0.10 \\
2.56 \pm 0.11\end{array}$ & $\begin{array}{l}1.09 \pm 0.06 \\
1.14 \pm 0.06 \\
1.48 \pm 0.05\end{array}$ & $\begin{array}{l}2.40 \pm 0.05 \\
2.56 \pm 0.07 \\
3.28 \pm 0.21\end{array}$ & $\begin{array}{l}0.40 \pm 0.05 \\
0.43 \pm 0.04 \\
0.52 \pm 0.04\end{array}$ \\
\hline
\end{tabular}


Table 2. Continued.

\begin{tabular}{|c|c|c|c|c|c|c|c|c|c|}
\hline \multirow[b]{2}{*}{ Analysis number } & \multicolumn{8}{|c|}{ Quaternary lava flows } & \multirow[b]{2}{*}{36} \\
\hline & 28 & 29 & 30 & 31 & 32 & 33 & 34 & 35 & \\
\hline Sample number & $79 \mathrm{SGV}-1111 \mathrm{~A}$ & $79 \mathrm{MH}-1111 \mathrm{~A}$ & $80 \mathrm{BM}-1002 \mathrm{~B}$ & 79 ZM-0078 & 79 LP-1109 & $79 \mathrm{ZZ}-1048$ & 80 LP-1033 & 80 LP-1034 & MGCR-600 \\
\hline \multicolumn{10}{|c|}{ Major-element chemical analyses (wt percent oxides) ${ }^{1}$} \\
\hline 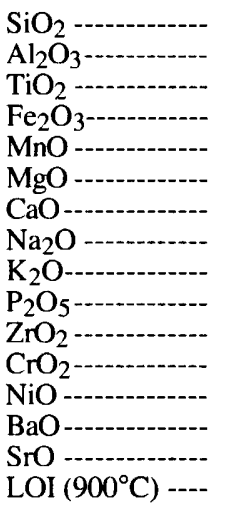 & $\begin{array}{c}60.6 \\
18.0 \\
0.80 \\
5.51 \\
0.10 \\
2.69 \\
6.13 \\
3.86 \\
1.26 \\
0.13 \\
0.01 \\
<0.005 \\
0.003 \\
0.02 \\
0.10 \\
1.10 \\
\end{array}$ & $\begin{array}{c}60.4 \\
18.1 \\
0.80 \\
5.55 \\
0.12 \\
2.71 \\
6.12 \\
3.81 \\
1.26 \\
0.12 \\
0.01 \\
<0.005 \\
0.003 \\
0.02 \\
0.10 \\
1.15 \\
\end{array}$ & $\begin{array}{l}49.2 \\
16.3 \\
1.78 \\
10.5 \\
0.15 \\
7.42 \\
8.24 \\
3.03 \\
0.96 \\
0.38 \\
0.02 \\
0.03 \\
0.012 \\
0.03 \\
0.06 \\
2.47 \\
\end{array}$ & $\begin{array}{l}55.5 \\
18.0 \\
1.19 \\
8.25 \\
0.12 \\
5.38 \\
7.33 \\
3.83 \\
0.78 \\
0.25 \\
0.02 \\
0.02 \\
0.01 \\
0.03 \\
0.074 \\
0.01 \\
\end{array}$ & $\begin{array}{l}52.3 \\
16.6 \\
1.35 \\
9.65 \\
0.15 \\
7.94 \\
8.94 \\
3.28 \\
0.85 \\
0.24 \\
0.02 \\
0.04 \\
0.016 \\
0.033 \\
0.08 \\
0.58 \\
\end{array}$ & $\begin{array}{l}60.4 \\
17.2 \\
0.94 \\
6.22 \\
0.09 \\
3.03 \\
6.17 \\
4.09 \\
1.68 \\
0.28 \\
0.01 \\
0.01 \\
0.004 \\
0.05 \\
0.12 \\
0.35 \\
\end{array}$ & $\begin{array}{l}61.3 \\
17.8 \\
0.80 \\
5.78 \\
0.09 \\
2.54 \\
5.45 \\
4.22 \\
1.15 \\
0.23 \\
0.02 \\
0.01 \\
0.004 \\
0.03 \\
0.07 \\
1.31 \\
\end{array}$ & $\begin{array}{c}63.9 \\
17.2 \\
0.63 \\
4.73 \\
0.07 \\
2.22 \\
5.17 \\
4.02 \\
1.33 \\
0.16 \\
0.02 \\
<0.005 \\
0.003 \\
0.03 \\
0.08 \\
0.76 \\
\end{array}$ & $\begin{array}{l}57.2 \\
17.8 \\
1.05 \\
6.81 \\
0.11 \\
2.09 \\
6.28 \\
3.58 \\
1.20 \\
0.24 \\
0.02 \\
<0.005 \\
0.002 \\
0.02 \\
0.12 \\
3.80 \\
\end{array}$ \\
\hline Total----------- & 100.32 & 100.27 & 100.58 & 100.79 & 102.07 & 100.64 & 100.80 & 100.33 & 100.33 \\
\hline \multicolumn{10}{|c|}{ Trace-element chemical analyses $(\mathrm{ppm})^{2}$} \\
\hline 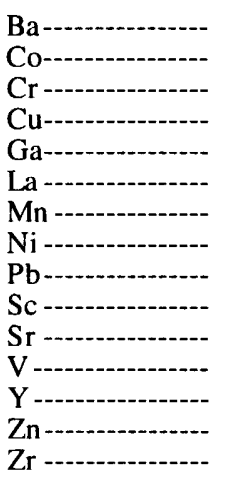 & $\begin{array}{r}180 \\
15 \\
17 \\
41 \\
18 \\
<20 \\
770 \\
20 \\
20 \\
12 \\
660 \\
100 \\
13 \\
52 \\
150\end{array}$ & $\begin{array}{r}160 \\
14 \\
<10 \\
32 \\
19 \\
<20 \\
840 \\
19 \\
20 \\
11 \\
620 \\
89 \\
13 \\
62 \\
160\end{array}$ & $\begin{array}{r}210 \\
38 \\
190 \\
44 \\
14 \\
<20 \\
1000 \\
120 \\
15 \\
26 \\
370 \\
170 \\
24 \\
100 \\
250\end{array}$ & $\begin{array}{r}240 \\
26 \\
130 \\
49 \\
18 \\
<20 \\
910 \\
79 \\
14 \\
19 \\
510 \\
130 \\
19 \\
80 \\
170\end{array}$ & $\begin{array}{r}230 \\
32 \\
290 \\
56 \\
15 \\
<20 \\
950 \\
150 \\
19 \\
28 \\
540 \\
200 \\
18 \\
95 \\
180\end{array}$ & $\begin{array}{r}460 \\
19 \\
41 \\
35 \\
18 \\
30 \\
730 \\
33 \\
15 \\
15 \\
750 \\
120 \\
18 \\
84 \\
260\end{array}$ & $\begin{array}{r}260 \\
13 \\
27 \\
26 \\
20 \\
<20 \\
680 \\
19 \\
10 \\
11 \\
500 \\
71 \\
13 \\
79 \\
180\end{array}$ & $\begin{array}{c}280 \\
9.7 \\
23 \\
26 \\
18 \\
<20 \\
550 \\
18 \\
14 \\
<10 \\
480 \\
53 \\
11 \\
65 \\
180\end{array}$ & $\begin{array}{r}140 \\
14 \\
<10 \\
55 \\
20 \\
<20 \\
870 \\
16 \\
<10 \\
11 \\
820 \\
110 \\
21 \\
83 \\
230\end{array}$ \\
\hline $\mathrm{K}-\mathrm{Ar}$ date $(\mathrm{Ma})^{3}-$ & $\begin{array}{l}1.14 \pm 0.05 \\
1.25 \pm 0.05 \\
1.30 \pm 0.03 \\
1.35 \pm 0.05 \\
\end{array}$ & & & $\begin{array}{l}0.63 \pm 0.06 \\
0.79 \pm 0.06\end{array}$ & $\begin{array}{l}1.30 \pm 0.13 \\
1.48 \pm 0.15\end{array}$ & $\begin{array}{l}0.45 \pm 0.06 \\
0.52 \pm 0.05\end{array}$ & & & \\
\hline
\end{tabular}




\begin{tabular}{|c|c|c|c|c|c|}
\hline \multirow[b]{2}{*}{ Analysis number } & \multicolumn{5}{|c|}{ Quaternary lava flows } \\
\hline & 37 & 38 & 39 & 40 & 41 \\
\hline Sample number & $81 \mathrm{MH}-10$ & $81 \mathrm{MH}-28$ & $81 \mathrm{MH}-29$ & $82 \mathrm{MH}-2$ & $82 \mathrm{MH}-12$ \\
\hline \multicolumn{6}{|c|}{ Major-element chemical analyses (wt percent oxides) ${ }^{1}$} \\
\hline 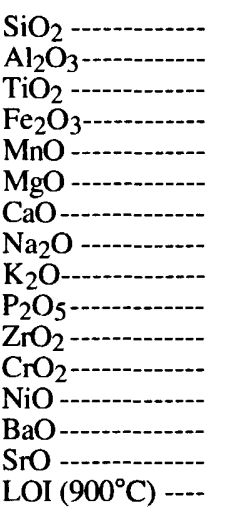 & $\begin{array}{l}57.6 \\
18.4 \\
0.98 \\
6.86 \\
0.10 \\
3.4 \\
6.72 \\
4.1 \\
0.96 \\
0.24 \\
0.02 \\
0.01 \\
\mathrm{Tr} \\
0.04 \\
0.06 \\
0.25 \\
\end{array}$ & $\begin{array}{l}59.5 \\
18.3 \\
0.76 \\
5.76 \\
0.09 \\
2.9 \\
6.68 \\
4.4 \\
0.96 \\
0.20 \\
0.02 \\
\mathrm{Tr} \\
\mathrm{Tr} \\
0.03 \\
0.07 \\
0.00 \\
\end{array}$ & $\begin{array}{l}60.8 \\
17.3 \\
0.84 \\
5.54 \\
0.09 \\
2.5 \\
5.92 \\
4.4 \\
1.62 \\
0.28 \\
0.02 \\
\mathrm{Tr} \\
\mathrm{Tr} \\
0.05 \\
0.08 \\
0.00 \\
\end{array}$ & $\begin{array}{l}59.4 \\
18.8 \\
0.92 \\
5.72 \\
0.09 \\
2.5 \\
6.48 \\
4.4 \\
1.02 \\
0.20 \\
0.01 \\
\operatorname{Tr} \\
\operatorname{Tr} \\
0.03 \\
0.10 \\
0.25 \\
\end{array}$ & $\begin{array}{l}56.5 \\
18.5 \\
1.10 \\
7.51 \\
0.12 \\
3.5 \\
6.84 \\
3.9 \\
0.90 \\
0.22 \\
0.01 \\
\mathrm{Tr} \\
\mathrm{Tr} \\
0.03 \\
0.10 \\
0.25 \\
\end{array}$ \\
\hline Total ---..-.-.-. & 99.74 & 99.67 & 99.44 & 99.92 & 99.48 \\
\hline \multicolumn{6}{|c|}{ Trace-element chemical analyses (ppm) ${ }^{2}$} \\
\hline 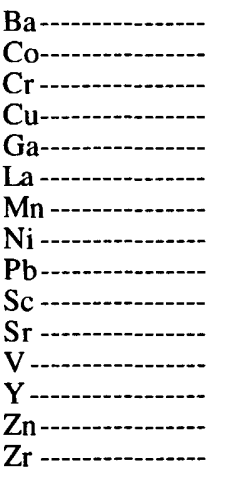 & $\begin{array}{r}430 \\
20 \\
47 \\
67 \\
22 \\
<10 \\
880 \\
21 \\
11 \\
16 \\
520 \\
130 \\
26 \\
74 * \\
172 *\end{array}$ & $\begin{array}{r}350 \\
17 \\
51 \\
33 \\
23 \\
<10 \\
780 \\
17 \\
<10 \\
12 \\
700 \\
78 \\
20 \\
64^{*} \\
154^{*}\end{array}$ & $\begin{array}{r}530 \\
17 \\
30 \\
38 \\
22 \\
16 \\
730 \\
16 \\
<10 \\
11 \\
880 \\
84 \\
22 \\
58^{*} \\
192^{*}\end{array}$ & $\begin{array}{r}270 \\
15 \\
23 \\
23 \\
22 \\
<10 \\
780 \\
15 \\
<10 \\
13 \\
1100 \\
100 \\
17 \\
56^{*} \\
146^{*}\end{array}$ & $\begin{array}{r}200 \\
23 \\
37 \\
26 \\
22 \\
<10 \\
1200 \\
18 \\
<10 \\
19 \\
650 \\
120 \\
25 \\
52^{*} \\
146^{*}\end{array}$ \\
\hline $\mathrm{K}-\mathrm{Ar}$ date $(\mathrm{Ma})^{3}-$ & $\begin{array}{l}0.49 \pm 0.06 \\
0.65 \pm 0.05 \\
0.63 \pm 0.07\end{array}$ & $\begin{array}{l}0.57 \pm 0.10 \\
0.29 \pm 0.08 \\
0.82 \pm 0.13 \\
0.57 \pm 0.05 \\
\end{array}$ & $\begin{array}{l}0.42 \pm 0.42 \\
0.36 \pm 0.36\end{array}$ & $\begin{array}{l}1.22 \pm 0.04 \\
1.02 \pm 0.04\end{array}$ & $0.15 \pm 0.02$ \\
\hline
\end{tabular}


Zigzag Mountain, and Last Chance Mountain, respectively. Chemical analyses of these rocks (table 2, analyses 4 through 14) indicate that the late Miocene lava flows are mostly andesites, except for one olivine basalt from Zigzag Mountain.

According to Wise (1969), the late Miocene volcanic rocks must have erupted from several vents surrounding the present-day site of Mount Hood. Available K-Ar age data suggest that the late Miocene volcanism on the north and west sides of the mountain was probably intermittent and ranged from about 5.4 to $10.7 \mathrm{Ma}$ in age. Wise (1969) proposed several volcanic centers of this age, on the south and east flanks of Mount Hood, and suggested that there may be additional sites of volcanism of about the same age. Wise (1969) mapped six small pyroxene andesite intrusive plugs to the north and south of Zigzag Mountain, and similar small intrusions south and southeast of Mount Hood. These intrusions may have been feeders for extensive post-Rhododendron, late Tertiary volcanism. One such intrusive plug located at the base of Enola Hill (fig. 1) has associated zeolite (chabazite, laumontite, mordenite, and stilbite), smectite, hematite, and chalcedony hydrothermal mineralization.

Wise (1969) mapped several hornblende andesite and dacite domes and flows at Mill Creek Buttes (northeast of Mount Hood) and Lolo Pass (northwest of Mount Hood) as being of Pleistocene age. K-Ar dating suggests that at least some of these units are older than the Pleistocene (1.6 Ma to $0.01 \mathrm{Ma}$ ). Hornblende dacite from one of the Mill Creek Buttes was dated at 7.5 Ma (White, 1979), and Keith and others (1985) obtained an age of about $6.21 \mathrm{Ma}$ for one of the hornblende dacite domes from Lolo Pass (table 2, analysis 6).

Two of the geothermal drill holes (Last Chance Mountain-data from this report-and Pucci Chairlift-data from Robison and others, 1981; table 1, Nos. 4 and 13, respectively) penetrated the late Miocene pyroxene andesite rocks. Hydrothermal minerals from the Tertiary sections of these two drill holes include pyrite, clay minerals (chlorite and smectite), calcite, epidote, gypsum, silica minerals (quartz, chalcedony, and B-cristobalite), and zeolite minerals (epistilbite, heulandite, laumontite, mordenite, and stilbite).

\section{STILL CREEK AND LAUREL HILL INTRUSIONS}

The Rhododendron Formation and some late Miocene andesites on Zigzag Mountain are intruded by the porphyritic hornblende-quartz diorite to quartz monzonite Laurel Hill and Still Creek intrusions (Wise, 1969). The Laurel Hill intrusion was dated at 8.0 and $8.4 \mathrm{Ma}$ by Bikerman (1970) and 8.8 and $8.6 \mathrm{Ma}$ by Keith and others (1985). Wise (1969) obtained an age of $11.6 \mathrm{Ma}$ for the Still Creek intrusion; Wise (1969) and Bikerman (1970) regard- ed this age as too old. White (1979) reported an age of 9.3 Ma for a lava flow cut by the Still Creek intrusion and suggested that the age may record the time of the Still Creek's emplacement. Wise (1969) indicated that the Laurel Hill and Still Creek intrusions might be the exposed parts of a much larger coextensive pluton. Plutonic rocks, lithologically similar to those of the Laurel Hill and Still Creek drill holes (table 1, Nos. 9 and 10), were found to the east in the Zigzag River drill hole (table 1, No. 8) (Covert and Meyer, 1979) and another drill hole (Thunderbird Lodge drill hole at Government Camp) (Steele and others, 1982) not included in this study. Also, several quartz microdiorite sills (possibly dikes) were penetrated in the OMF-1 (table 1, No. 5) and OMF-7A drill holes, and a sample from $3,750 \mathrm{~m}$ depth in the OMF-7A drill hole has been dated at 9.3 Ma (Priest and others, 1982). Thus, radiometric age data suggest that the Laurel Hill and Still Creek intrusions were emplaced between about 8.0 and 9.3 Ma.

Rocks from the Laurel Hill and Still Creek intrusions sampled for this study consist of medium-dark-gray, medium- to fine-grained rocks that range in composition from quartz diorite to quartz monzonite (table 2, analyses 15 through 19). These rocks contain phenocrysts of plagioclase and hornblende in a groundmass of plagioclase, potassium feldspar, quartz, hornblende, and magnetite. Most drill-hole cuttings and outcrops sampled were slightly to extensively altered; secondary minerals include actinolite, chlorite, epidote, hematite, clay minerals (smectite, illite, and mixedlayer chlorite-smectite), zeolite minerals (chabazite, epistilbite, heulandite, laumontite, scolecite, stilbite, and wairakite), sulfide minerals (chalcopyrite and pyrite), magnetite, quartz, adularia, prehnite, chrysocolla, and calcite.

\section{OTHER INTRUSIVE ROCKS}

Intrusive activity continued after the Laurel Hill-Still Creek plutonism because the Laurel Hill mass is itself intruded by andesite and basalt dikes, one of which has an age of 5.0 Ma (Bikerman, 1970). On the southeastern side of Mount Hood, Goldstein and others (1982), from a magnetotelluric study, suggested the presence of an elongate zone of resistive (presumably intrusive) rock extending from Lookout Mountain to Barlow Butte (fig. 1). They pointed out that the resistive zone is correlative with a Bouguer gravity high located by Couch and Gemperle (1979).

The present study located several quartz diorite dikes (up to about $10 \mathrm{~m}$ in width) that intrude the late Miocene pyroxene andesites within the resistive zone. Keith and others (1985) obtained an age of 5.26 Ma on a plagioclase separate from one of the freshest dikes (table 2, analysis 20). Extensive alteration was observed at several outcrops between Barlow Butte and Lookout Mountain. Secondary 
minerals in this area include pyrite, clay minerals (chlorite, illite, smectite, and kaolinite), silica minerals (quartz and chalcedony), prehnite, epidote, adularia, calcite, zeolite minerals (ferrierite, laumontite, and mordenite), and iron oxides (hematite and goethite).

\section{PLIOCENE ANDESITIC LAVA FLOWS}

Basaltic to dacitic lava flows of late Pliocene age cap several of the ridges and buttes that partly encircle Mount Hood; they probably were erupted from several different vents (Wise, 1969). Andesites on the east side of Mount Hood (Lookout Mountain and an unnamed mountain a few kilometers to the southwest) have ages of 3.0 and 4.1 Ma, respectively (Wise, 1969). Wise (1969) provided major-oxide chemical analyses and petrographic descriptions of several other Pliocene lava flows to the east of Mount Hood and from Zigzag Mountain on the west side of Mount Hood. Keith and others (1985) obtained a K-Ar age of about 1.8 Ma (average of two analyses) for pyroxene andesite lavas on top of Bluegrass Ridge and an age of 2.7 Ma for a hornblende-pyroxene andesite lava flow located about $3.2 \mathrm{~km}$ east of Bluegrass Ridge (fig. 1). At Zigzag Mountain, Keith and others (1985) obtained ages of about $2.7 \mathrm{Ma}$ for an olivine basalt flow and about 2.4 Ma for a pyroxene andesite flow (table 2, analyses 23 and 24). Major-oxide and trace-element chemical analyses of these rocks are given in table 2 (analyses 22 through 26). Keith, Beeson, and Bargar (1982) indicated that the late Pliocene lavas are less faulted and altered than the late Miocene and early Pliocene lavas.

\section{QUATERNARY VOLCANIC ACTIVITY}

Approximately 90 percent of the nearly $188 \mathrm{~km}^{3}$ of andesitic to dacitic lava flows, pyroclastic flows, and mudflows that compose Mount Hood formed prior to the Fraser glaciation, are normally magnetized, and must have been deposited during the period $700 \mathrm{ka}$ to $13 \mathrm{ka}$ (Wise, 1969; Williams and others, 1982). Petrographic and geochemical studies of these rocks conducted by Wise (1968, 1969), White (1979, 1980), Wollenberg and others (1979), and this study (table 2, analyses 27 through 41 ) suggest that the rocks are mostly unaltered. In a study of Timberline Lodge 3 drill-hole cuttings, White (1979) reported finding only a little pyrite mineralization.

Basalt to andesite lavas that have erupted from satellite vents to the north and west of Mount Hood (Sandy Glacier volcano, Cloud Cap, The Pinnacle, Red Hill, Vista Ridge, and a vent near Lolo Pass) are believed to be of Pleistocene age because of field relations or $\mathrm{K}-\mathrm{Ar}$ dating (Wise, 1969; Keith, Beeson, and Bargar, 1982; Keith and others, 1985). The latest periods of volcanic activity at Mount Hood occurred about 15 to $12 \mathrm{ka}, 1.8$ to $1.4 \mathrm{ka}, 0.6$ to 0.4 ka, and 0.25 to 0.18 ka (Crandell, 1980; Cameron and Pringle, 1986, 1987). Harris $(1976,1988)$ compiled several accounts of minor volcanic activity at Mount Hood that were reported in the mid-1800's.

Detailed heat-flow studies of the Mount Hood area show that the geothermal gradient increases toward the apex of the mountain; at a distance of about $5 \mathrm{~km}$ from the volcano the gradient is about double the mean regional heat-flow values (Steele and others, 1982). At present, the only indications of thermal activity at Mount Hood are the Crater Rock fumaroles near the summit of the mountain and Swim Warm Springs near its southern base (fig. 3). According to Wollenberg and others (1979), chemical analyses of these mildly warm $\left(20^{\circ}-26^{\circ} \mathrm{C}\right)$ springs and several cold springs on Mount Hood suggest mixing of thermal water and surface runoff water. Calculations of mixing models and chemical geothermometers indicate that geothermal water at depth beneath Mount Hood may be as hot as $240^{\circ} \mathrm{C}$ (Wollenberg and others, 1979). Extensive fumarolic activity near the summit of Mount Hood has been mapped by infrared imagery, and the pattern of hot ground is believed to have resulted from structural controls (Friedman and others, 1982). Chemical analyses of the largely $\mathrm{CO}_{2}$ and $\mathrm{H}_{2} \mathrm{~S}$ fumarolic gases were reported in Wollenberg and others (1979) and Nehring and others (1981). Hot rocks bathed by the fumarolic gases are subject to acid-sulfate leaching and deposition of silica minerals (opal and chalcedony), clay minerals (kaolinite and smectite), elemental sulfur, sulfate minerals (anhydrite, gypsum, alunite, and natrojarosite), iron oxide minerals (hematite, "specularite," and amorphous phases), and goethite (Beeson and others, 1980).

Several erosional and mass-wasting processes, such as stream erosion, recent landslides and debris or mud slides (Gallino and Pierson, 1984), and glacial transport of volcaniclastic materials (fig. 4), have operated and continue to operate at Mount Hood. Eight of the 13 geothermal drill holes in this study penetrate Quaternary lava flows with intervening volcaniclastic debris units. The lava flows are generally unaltered; however, several reworked detritus layers contain siliceous, orange- to red-stained and whitebleached grains (frequently rounded) that consist of many minerals (opal, chalcedony, alunite, kaolinite, smectite, and hematite) attributed to fumarolic alteration at the summit of Mount Hood by Beeson and others (1980).

\section{HYDROTHERMAL ALTERATION MINERALOGY}

Drilling records indicate that hydrothermal minerals are sparse or absent in many of the $\mathbf{3 0}$ drill holes completed in the vicinity of Mount Hood. Lithologic descriptions and distribution of hydrothermal minerals are reported here for 13 of the drill holes (appendix A; table 1). Brief lithologic 
descriptions of the drill cuttings previously were given for the seven USGS drill holes (Robison and others, 1981); the hydrothermal mineralogy of one of these drill holes (Pucci Chairlift) was studied by Gannett and Bargar (1981). Bargar (1980a, b) described the hydrothermal mineral phases present in the Lost Creek and Snow Bunny drill holes. Geophysical data, lithologic descriptions, and some hydrothermal mineralogical data for drill cuttings from the OMF-1 drill hole have been published by the Oregon Department of Geology and Mineral Industries (1978) and Priest and Vogt (1982); additional data on the hydrothermal mineralogy of drill hole OMF-1 are given in this report. White (1979) described the lithology and hydrothermal mineralization of the Timberline 3 drill hole. A comprehensive study of the OMF-7A drill hole was made by Priest and others (1982) and Holdaway and Bussey (1982).

\section{SILICA MINERALS}

Hydrothermal silica phases, identified in drill cuttings and rock samples collected near Mount Hood, include opal, B-cristobalite, chalcedony, and quartz. Using a binoc- ular microscope, quartz can be readily distinguished from the other silica phases because of its distinctive habit of forming colorless crystals. The other three phases, in general, can only be distinguished with a petrographic microscope or by X-ray diffraction methods. In our study, opal was identified by a very broad $\mathrm{X}$-ray reflection at about $4.04 \AA$, and B-cristobalite was identified by a broad reflection between 4.07 and $4.11 \AA$ and a single minor reflection near $2.50 \AA$; the X-ray diffraction pattern for chalcedony (cryptocrystalline quartz) is the same as that of quartz. Two other silica phases that are present in the samples collected for this study are $\alpha$-cristobalite and tridymite: $\alpha$ cristobalite (sharp major X-ray reflection between 4.04 and $4.07 \AA$ along with several minor peaks) is a product of devitrification of volcanic glass, and tridymite (major $\mathrm{X}$-ray reflections at $3.82,4.11$, and $4.32 \AA$, plus many minor reflections) forms by vapor-phase crystallization during initial cooling stages of the lava flows.

\section{OPAL}

Several exotic rock fragments, collected just south of Cloud Cap on the east side of Mount Hood and near Sandy

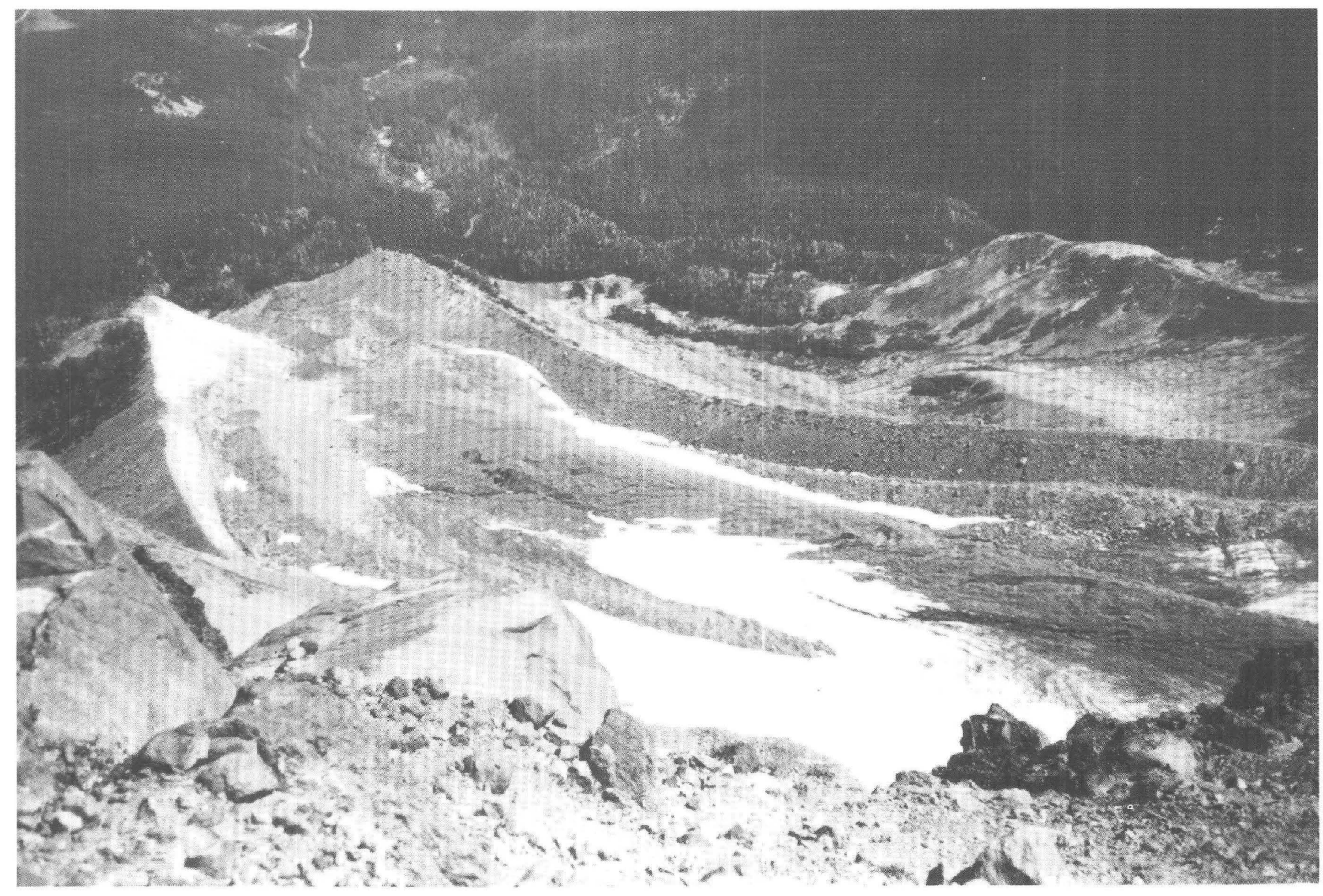

Figure 4. Lateral moraine deposits below Coe Glacier on the north side of Mount Hood. 
Glacier volcano on the west side of the mountain (fig. 1), contain coatings or open-space fillings of opal that is colorless to white or is yellow to orange stained and sometimes has a colloform morphology. In addition to opal, the Sandy Glacier volcano samples contain associated specular hematite, kaolinite, alunite, gypsum, and anhydrite. X-ray diffraction analyses of a sample from the east side of Mount Hood show the presence of chalcedony plus reflections at $3.15,9.6$, and $19.2 \AA$, which might correspond to truscottite, a hydrated calcium silicate mineral. These rock samples are presumed to have formed and been altered close to the summit of Mount Hood by fumarolic processes (Beeson and others, 1980) and subsequently tumbled down the side of the mountain to the collection sites.

Drill cuttings from volcaniclastic debris intervals in six Mount Hood drill holes (table 1, Nos. 1, 2, 5, 7, 12, and 13) contain bluish, white, cream, yellowish, or orangish monomineralic grains of opal, or grains composed of opal in association with alunite, natroalunite, hematite, kaolinite, smectite, gypsum, anhydrite, or pyrite. These minerals probably formed near the summit of Mount Hood because of near-vent fumarolic alteration and subsequently were transported downslope as colluvium, mudflow, landslide, fluvial, or pyroclastic deposits that now constitute the volcaniclastic debris intervals (Naboko, 1959; Crandell, 1971).

\section{B-CRISTOBALITE}

B-cristobalite, probably similar in origin to opal, was identified in a few Quaternary volcaniclastic debris samples from drill cuttings in three (table 1, Nos. 2, 4, and 13) of the Mount Hood drill holes. Only a single grain of white B-cristobalite was found in drill cuttings from drill hole 13. In drill hole 2, orange-, red-, or green-colored drill-cuttings chips, consisting of B-cristobalite in association with minor hematite, smectite, calcite, or mordenite, apparently formed as vesicle fillings or cement coatings on volcaniclastic grains. White, colloform, B-cristobalite grains, sometimes associated with chalcedony and smectite, appear to fill vesicles in the volcaniclastic debris section of the Rhododendron Formation in drill hole 4; similar-appearing white $B$-cristobalite grains occur as hydrothermal fracture fillings in a late Miocene andesitic lava flow higher in this drill hole.

\section{CHALCEDONY}

Chalcedony was identified in 9 of the 13 Mount Hood drill holes studied (table 1, Nos. 1, 3, 4, 5, 6, 7, 10, 11, and 13). In the Quaternary volcaniclastic debris units, chalcedony mostly occurs as red- to orange-stained or whitebleached grains that frequently are found with one or more associated secondary minerals such as smectite, kaolinite, alunite, natroalunite, jarosite, hematite, $B$-cristobalite, opal, or pyrite. The mode of its occurrence and some of the minerals associated with it suggest that the chalcedony may have a similar origin as opal. Chalcedony commonly originates as the less stable amorphous silica (opal) phase and later is structurally converted to chalcedony. According to White and others (1988), the conversion process probably includes an intermediate B-cristobalite stage and takes place in a neutral to slightly alkaline environment.

Cloudy, colorless, bluish, or white chalcedony, often with a colloform texture or banded structure, was identified in drill cuttings of Tertiary and Quaternary lava flows and Tertiary volcaniclastic units (Rhododendron Formation). Chalcedony from these drill-hole intervals appears to occur as open-space fracture or vesicle fillings and probably is of hydrothermal origin. Associated secondary minerals include smectite, hematite, calcite, pyrite, heulandite, stilbite, and laumontite. Milky white, microcrystalline quartz or chalcedony vein fillings occur in association with epidote, chlorite, mixed-layer illite-smectite, and an amphibole in two grains from widely separated intervals in the Quaternary volcaniclastic part of the Lost Creek drill hole (table 1, No. 7). The two grains appear to be from a Tertiary intrusive source, and the associated secondary minerals suggest a moderately high formation temperature $\left(>200^{\circ} \mathrm{C}\right)$. Gray or white, colloform chalcedony deposits also fill fractures in surface outcrops of Tertiary lava flows and intrusive dikes near Mount Hood.

\section{QUARTZ}

Grains of colorless, massive quartz or euhedral quartz crystals were identified in drill cuttings from seven of the Mount Hood drill holes (table 1, Nos. 4, 5, 6, 8, 9, 10, and 13). A few quartz grains were found in Quaternary alluvial deposits, but they are much more plentiful, apparently as vesicle and fracture fillings, in drill cuttings of the older Tertiary intrusive rocks, andesite flows, Rhododendron Formation, and Columbia River Basalt Group. Hydrothermal minerals found at the same sample depths as quartz grains include pyrite, smectite, calcite, hematite, chalcedony, stilbite, epidote, and magnetite. Quartz grains in these drill holes usually are monomineralic, so the paragenetic relations between quartz and the above-mentioned hydrothermal alteration minerals were mostly not observed. Outcrops of Tertiary igneous rocks near Mount Hood also contain quartz crystals as vesicle fillings or fracture coatings and between breccia fragments. About half the secondary minerals listed in appendix B are found in association with quartz crystals in these outcrops. The quartz crystals frequently formed earlier than other secondary minerals, although some open-space fillings contain earlier minerals such as epidote and chlorite. 


\section{CARBONATE MINERALS}

\section{DOLOMITE}

A dolomite-group mineral occurs as open-space fillings of colorless to white colloform clusters of rhombic crystals (fig. 5) or as white veins in six samples from the 67.0to 91.4-m-depth interval in the McGee Creek drill hole (table 1, No. 3). Its classification as a dolomite-group mineral is suggested by the most intense $d(104) \mathrm{X}$-ray reflection, occurring at about 2.90 to $2.92 \AA$. According to the Mineral Powder Diffraction File (MPDF) card 11-78, the $d(104)$ reflection for dolomite is at $2.89 \AA$, ankerite has a $d(104)$ reflection at $2.90 \AA$ (MPDF card 33-282), and magnesium kutnohorite has a $d(104)$ reflection at $2.91 \AA$ (MPDF card 20-225). Semiquantitative chemical analysis of carbonate from $79.2 \mathrm{~m}$ depth in the McGee Creek drill hole, using an X-ray energy dispersive spectrometer (EDS) on a scanning electron microscope (SEM), indicated $\mathrm{Ca}>\mathrm{Mg}>\mathrm{Mn}$; no $\mathrm{Fe}$ was observed (analysis of a nearby grain shows that $\mathrm{Mn}$ is the dominant cation with some $\mathrm{Ca}$ and a trace of $\mathrm{Mg}$; the mineral probably is a manganoan calcite). Deer and others (1966) considered dolomite to have a $\mathrm{Mg}: \mathrm{Fe}$ ratio of $>4$, whereas ankerite has a $\mathrm{Mg}: \mathrm{Fe}$ ratio of $<4$. X-ray diffraction data suggests that the mineral may not be dolomite, and because no $\mathrm{Fe}$ was found in the EDS analysis, ankerite can be eliminated. From the above chemical and X-ray data, it appears that the mineral might be a magnesium kutnohorite (Tsusue, 1967); however, the index of refraction $(\sim 1.68)$ is much too low. Hydrothermal minerals occurring in the same drill cuttings samples as this dolomite-group mineral include heulandite, smectite, hematite, and manganoan calcite.

An obscure mining district known as the Cheeney Creek area, about $25 \mathrm{~km}$ southwest of Mount Hood, was described briefly by Callaghan and Buddington (1938, p. 8182 ). According to their report, the area was mined near the beginning of this century, but never yielded very much gold ( $<49$ ounces); only a single adit, a minor excavation, and a nearby tailings pile were visited during this study. Two samples collected from the tailings pile have white carbonate vein material associated with quartz, sphalerite(?), and manganoan calcite. The white vein mineral has a major X-ray diffraction reflection near $2.90 \AA$, and the index of refraction is $\sim 1.68$. A semiquantitative chemical analysis by EDS on an SEM indicates that $\mathrm{Ca}>\mathrm{Mg}>\mathrm{Fe}$, with a $\mathrm{Mg}: \mathrm{Fe}$ ratio slightly greater than four; the mineral is tentatively identified as dolomite. Callaghan and Buddington (1938) reported finding dolomite in this area.

Yellowish, massive to rhombic carbonate crystals, in association with calcite, cerussite, sphalerite, chalcopyrite, galena, pyrite, and illite, fill spaces between quartz crystals in a $~ 0.3-\mathrm{m}$-thick quartz vein on the north side of Zigzag Mountain. The crystals have an index of refraction of $\sim 1.67$ and a $d(104) \mathrm{X}$-ray peak near $2.89 \AA$. Semiquantita- tive chemical analysis by EDS on an SEM suggest that $\mathrm{Ca}>\mathrm{Mg}>\mathrm{Fe}>\mathrm{Mn}$, and the $\mathrm{Mg}: \mathrm{Fe}$ ratio is less than four. Chemical data suggest that the mineral might be ankerite, but the index of refraction and X-ray data do not support this identification.

Index of refraction measurements, X-ray diffraction analyses, and semiquantitative chemical data do not provide an unequivocal identification for any of these three dolomite-group minerals. Consequently, throughout this report the minerals are simply reported as dolomite.

\section{MANGANOAN CALCITE AND RHODOCHROSITE}

A single X-ray diffraction analysis of a bulk sample from $103.6 \mathrm{~m}$ depth in the McGee Creek drill hole (table 1 , No. 3) contained a minor X-ray reflection at $2.84 \AA$, suggesting the presence of rhodochrosite. Several other drill cuttings between depths of $67.1 \mathrm{~m}$ and $118.9 \mathrm{~m}$ in the same drill hole have X-ray reflections between 2.98 and $3.01 \AA$, corresponding to manganoan calcite (Krieger,

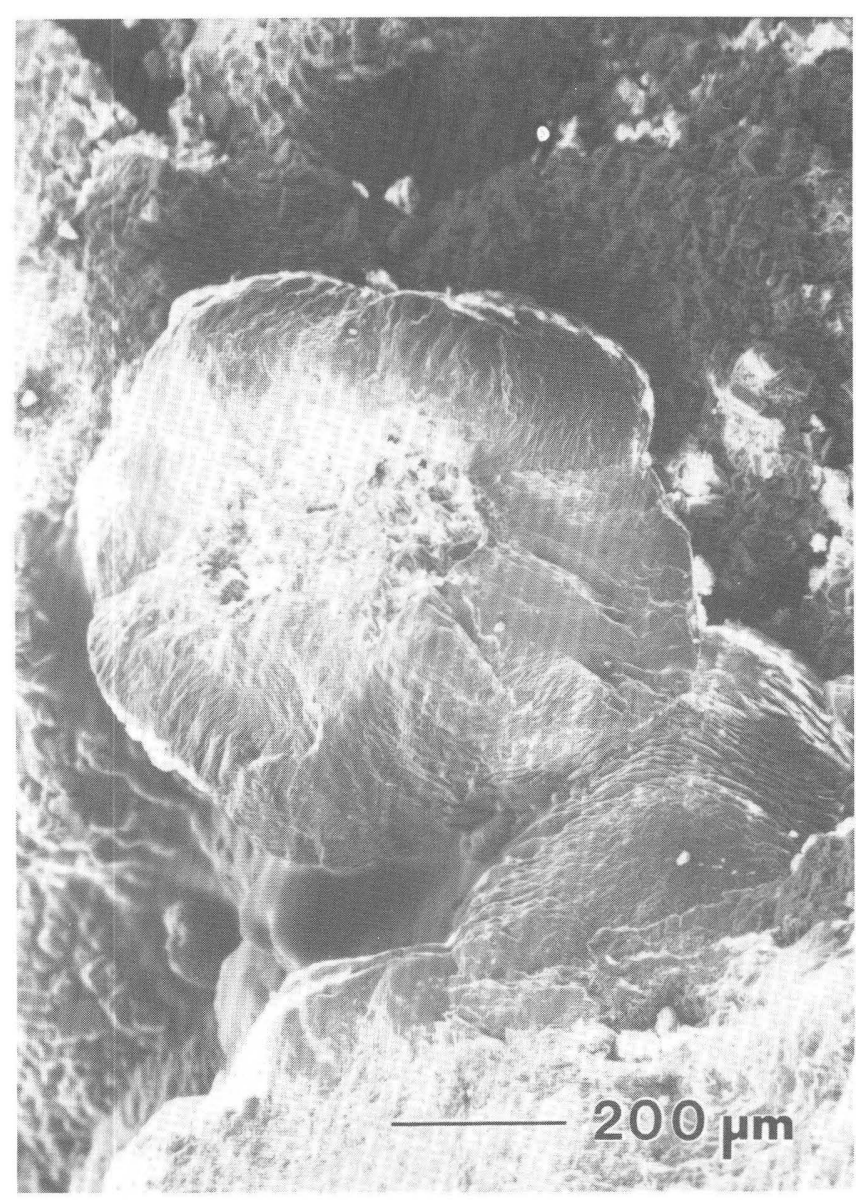

Figure 5. Scanning electron micrograph showing botryoidal aggregates of rhombic dolomite crystals from $79.2 \mathrm{~m}$ depth in the McGee Creek drill hole. 
1930). One sample at $112.8 \mathrm{~m}$ depth has a double X-ray peak at 3.04 and $2.99 \AA$, indicating that both calcite and manganoan calcite are present. Microscope observations of the drill cuttings from several samples near this depth suggest that the two carbonate phases may be present in other samples not examined in detail.

Three samples of white vein material, collected from a tailings pile in the Cheeney Creek area (Callaghan and Buddington, 1938), have X-ray diffraction reflections at $3.01 \AA$, suggesting that the material consists of manganoan calcite (Krieger, 1930). Associated hydrothermal minerals include quartz, siderite, dolomite, and sphalerite(?).

\section{SIDERITE}

According to MPDF file card 29-696, siderite has a major X-ray reflection at $2.80 \AA$. Four samples examined in this study have intense $\mathrm{X}$-ray reflections between 2.79 and $2.81 \AA$ and thus are probably siderite. A siliceous grain at $45.7 \mathrm{~m}$ depth in the McGee Creek drill hole (table 1, No. 3 ) consists of chalcedony, smectite, calcite, and siderite. Brown grains at depths of $338.3 \mathrm{~m}$ and $341.4 \mathrm{~m}$ in the Clear Fork drill hole (table 1, No. 6) are composed of siderite and quartz. One vein filling sample collected from the tailings pile in the Cheeney Creek area contains siderite, quartz, and manganoan calcite.

\section{CERUSSITE}

Cerussite was identified at two locations in the Mount Hood area. Several samples collected from a tailings dump in the Cheeney Creek area contain euhedral, colorless to white, acicular to columnar crystals (fig. 6) that were identified as cerussite by $\mathrm{X}$-ray diffraction. Associated minerals include galena, anglesite, sphalerite, pyrite, limonite, calcite, and quartz. Similarly, white acicular cerussite crystals were identified in two samples from a quartz vein on the north side of Zigzag Mountain in association with calcite, dolomite, sphalerite, chalcopyrite, galena, pyrite, and illite. Cerussite commonly forms as an alteration product of galena, with anglesite as an intermediate stage, in oxide zones of lead-ore deposits (Park and MacDiarmid, 1964).

\section{CALCITE}

Calcite (major X-ray reflection near $3.03 \AA$ ), a very common hydrothermal mineral in the Mount Hood area, was identified in drill cuttings of all except two of the geothermal drill holes; calcite is present in many of the outcrop samples collected near Mount Hood (appendix B). Many drill-cuttings samples contain subrounded to angular, colorless to white (rarely brown), massive to blocky, crystal fragments that appear to be vein or vesicle fillings in association with one or more other hydrothermal minerals (dolomite, manganoan calcite, pyrite, smectite, quartz, stilbite, chabazite, laumontite, chlorite, chalcedony, mixedlayer illite-smectite, siderite, mixed-layer chlorite-smectite, epidote, scolecite, and wairakite).

Outcrop samples of some rock units penetrated by the geothermal drill holes show details of crystal morphology and paragenesis not seen in the shallow geothermal-gradient drill-hole samples. Colorless or white (rarely brown) calcite crystal habits vary from massive to blocky or are bladed in open-space fillings of vesicles, microfractures, or between breccia fragments. Plagioclase phenocrysts in intensely altered areas have been almost completely converted to calcite. On the other hand, a few aggregates of quartz crystals appear to be pseudomorphs after bladed calcite. In addition to most of the hydrothermal minerals listed above as associated with calcite in samples of drill cuttings, calcite outcrop samples also contain illite, hematite, cerussite, adularia, sphalerite, and galena.

\section{ZEOLITE MINERALS}

\section{WAIRAKITE}

Two vein fillings in an andesite flow of the Rhododendron Formation contain tiny subhedral wairakite crystals (fig. 7). Both samples were obtained just a few meters from the Laurel Hill intrusion (figs. 1 and 3), and extensive mineralization observed at the outcrop undoubtedly is related to

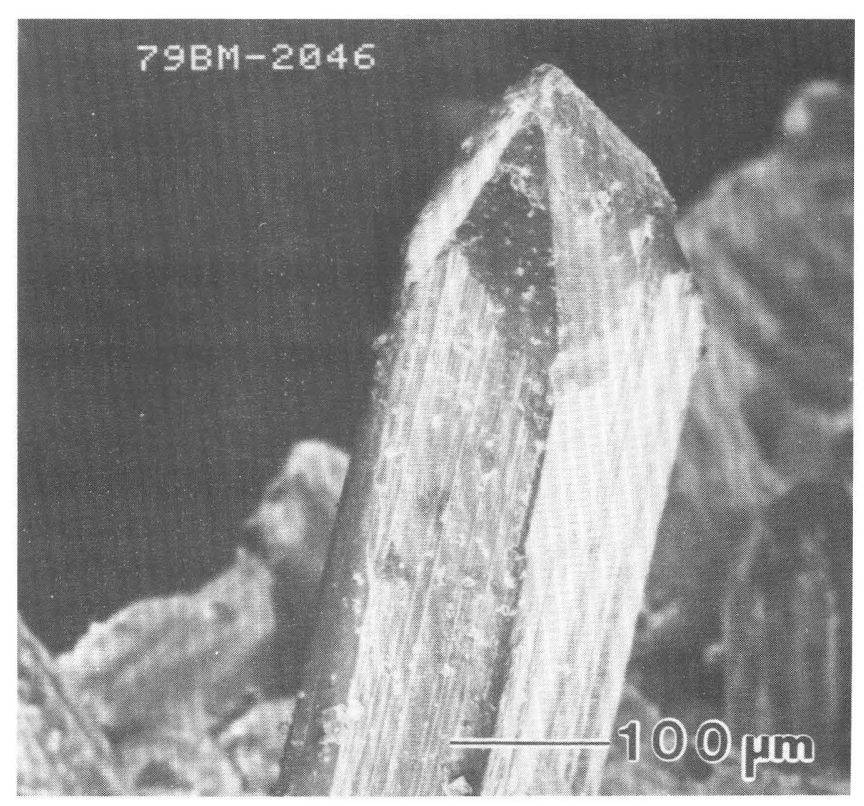

Figure 6. Scanning electron micrograph showing an acicular cerussite crystal from a tailings pile in the Cheeney Creek Mining Area, southwest of Mount Hood. Striations may be due to polysynthetic twinning. 
this quartz diorite intrusion. Other minerals identified in these two samples include epidote, smectite, chlorite, hematite, and chabazite. X-ray diffraction analysis of both vein deposits show a reflection near $13^{\circ} 2 \theta(\mathrm{Cu} \mathrm{K \alpha})$ and double reflections at about $26.2^{\circ} 2 \theta$; both mineral samples appear to be wairakite, based on X-ray data reported by Coombs (1955), rather than analcime, which is the $\mathrm{Na}$ end member of the analcime-wairakite isomorphous series. Subsequent electron-microprobe analyses (table 3 ) confirmed the identification of the $\mathrm{Ca}$ end-member wairakite. Analyses for specimen 79CCQ-2001B in table 3 appear to be very near the stoichiometric formula for wairakite; however, analyses of specimen $79 \mathrm{LH}-0087 \mathrm{~F}$ contain significant $\mathrm{K}_{2} \mathrm{O}$, which is present in much greater abundance than in other reported chemical analyses for wairakite (Gottardi and Galli, 1985). Experimental data of Zeng and Liou (1982) suggest that wairakite forms at temperatures exceeding about $220^{\circ} \mathrm{C}$.

Drill cuttings in three of the Mount Hood drill holes (table 1, Nos. 8, 9, and 10) contain small amounts of wairakite identified by $\mathrm{X}$-ray diffraction. In all three drill holes, wairakite was found only in quartz diorite chips of the Laurel Hill or Still Creek intrusions, suggesting its probable origin as a hydrothermal alteration product of these intrusions. Other hydrothermal minerals in the wairakite-bearing drill cuttings include epidote, quartz, chabazite, laumontite, stilbite, calcite, chlorite, smectite, illite(?) and pyrite.

\section{CHABAZITE}

White to colorless, euhedral, pseudocubic, rhombohedral, chabazite crystals (fig. 8) were observed in drill cut-

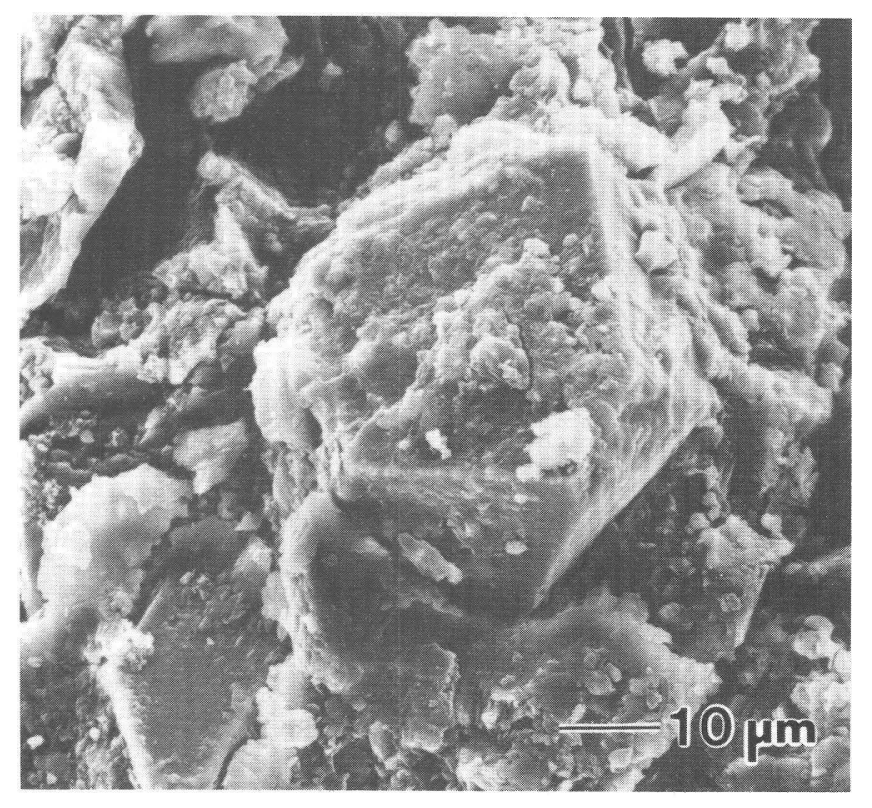

Figure 7. Scanning electron micrograph showing subhedral wairakite crystals and later chlorite vein filling in specimen 79CCQ-2001B in altered volcanic rocks of the Rhododendron Formation near the Laurel Hill intrusion.
Table 3. Electron-microprobe analyses of wairakite from outcrops associated with the Laurel Hill intrusion.

\begin{tabular}{|c|c|c|c|c|c|c|}
\hline \multirow{2}{*}{$\begin{array}{l}\text { Sample number --.-- } \\
\text { Analysis number---.--- }\end{array}$} & \multicolumn{3}{|c|}{ 79LH-0087F } & \multicolumn{3}{|c|}{$79 \mathrm{CCQ}-2001 \mathrm{~B}$} \\
\hline & 2 & 4 & 7 & 1 & 3 & 7 \\
\hline \multicolumn{7}{|c|}{ Major-element chemical analysis (wt percent oxides) } \\
\hline $\mathrm{SiO}_{2}-\cdots$ & 59.68 & 58.61 & 58.76 & 55.70 & 55.09 & 54.78 \\
\hline $\mathrm{Al}_{2} \mathrm{O}_{3}$ & 21.18 & 20.72 & 20.43 & 23.19 & 23.61 & 23.28 \\
\hline $\mathrm{Fe}_{2} \mathrm{O}_{3}$ & 0.00 & 0.03 & 0.00 & 0.04 & 0.00 & 0.04 \\
\hline MgO--a- & 0.51 & 0.80 & 0.88 & 0.05 & 0.04 & 0.03 \\
\hline $\mathrm{MnO}-$ & 0.00 & 0.01 & 0.00 & 0.01 & 0.00 & 0.00 \\
\hline $\mathrm{CaO}-1-$ & 9.51 & 8.77 & 8.54 & 12.66 & 12.99 & 13.13 \\
\hline $\mathrm{Na}_{2} \mathrm{O}-$ & 0.16 & 0.15 & 0.14 & 0.18 & 0.02 & 0.05 \\
\hline $\mathrm{K}_{2} \mathrm{O}$ & 1.34 & 1.53 & 1.80 & $\underline{0.01}$ & $\underline{0.01}$ & $\underline{0.00}$ \\
\hline 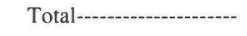 & 92.38 & 90.62 & 90.55 & 91.84 & 91.76 & 91.35 \\
\hline
\end{tabular}

Number of atoms on the basis of 96 oxygens

\begin{tabular}{|c|c|c|c|c|c|c|}
\hline $\mathrm{Si}-\cdots$ & 33.95 & 33.98 & 34.11 & 32.16 & 31.68 & 31.88 \\
\hline $\mathrm{Al}$ & 14.20 & 14.16 & 13.98 & 15.78 & 16.00 & 15.97 \\
\hline Fe--- & 0.00 & 0.01 & 0.00 & 0.02 & 0.00 & 0.02 \\
\hline Mg-1- & 0.43 & 0.69 & 0.76 & 0.04 & 0.03 & 0.03 \\
\hline $\mathrm{Mn}-$ & 0.00 & 0.01 & 0.00 & 0.01 & 0.00 & 0.00 \\
\hline 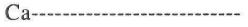 & 5.80 & 5.45 & 5.31 & 7.83 & 8.00 & 8.21 \\
\hline $\mathrm{Na}-1-1$ & 0.18 & 0.17 & 0.16 & 0.20 & 0.03 & 0.06 \\
\hline K-- & 0.98 & 1.13 & 1.33 & 0.00 & 0.01 & 0.00 \\
\hline $\mathrm{Si}+\mathrm{Al}-$ & 48.15 & 48.13 & 48.08 & 47.94 & 47.68 & 47.85 \\
\hline $\mathrm{Si} / \mathrm{Al}+\mathrm{Fe}^{3+}$ & 2.39 & 2.40 & 2.44 & 2.04 & 1.98 & 2.00 \\
\hline Balance error ${ }^{1}$ & 4.42 & 4.25 & 2.45 & -1.01 & -0.61 & -3.35 \\
\hline
\end{tabular}

'Determined by the method of Passaglia (1970).

tings from five of the Mount Hood drill holes (table 1, Nos. 5, 7, 8, 9, and 10), as well as several outcrop samples obtained near Laurel Hill and Zigzag Mountain (fig. 1). The chabazite occurs as fracture fillings in quartz diorites of the Laurel Hill intrusion and in altered volcaniclastic deposits and andesite flows of the Rhododendron Formation. Chabazite commonly was deposited later than chlorite, epidote, and quartz, and it probably formed at much lower temperatures than these minerals; in Icelandic geothermal areas, chabazite occurs at temperatures lower than $100^{\circ} \mathrm{C}$ (Kristmannsdóttir and Tómasson, 1978). Laboratory studies have produced chabazite at atmospheric pressure and at temperatures below $100^{\circ} \mathrm{C}$ (Tomita and others, 1969). Other hydrothermal minerals identified in the chabazite-bearing samples include calcite, stilbite, stellerite(?), mixed-layer chlorite-smectite, laumontite, smectite, hematite, mixed-layer chlorite-vermiculite(?), epistilbite, prehnite(?), pyrite, wairakite, illite, heulandite, magnetite, scolecite, chalcopyrite, and chrysocolla (appendix B).

The chemical composition of chabazite, especially chabazite of hydrothermal origin, is quite variable, and major cations can be $\mathrm{Ca}, \mathrm{K}, \mathrm{Na}$, or $\mathrm{Sr}$ (Gottardi and Galli, 1985). Microprobe analyses of chabazite from near Mount Hood mostly are rich in $\mathrm{Ca}$, have a significant $\mathrm{K}$ content, and generally are low in $\mathrm{Na}$ (table 4). However, chemical analyses for one specimen (KCR-760-1; table 4, analysis 1) from the Zigzag River drill hole (table 1, No. 8) vary from near the schematic Ca-rich (very low $\mathrm{Na}$ and $\mathrm{K}$ ) formula 
given by Gottardi and Galli (1985) to chabazite containing significant Na. Balance errors (Passaglia, 1970) of the chabazite analyses listed in table 4 are less than 7 , and the analyses appear to be very good; however, if $\mathrm{H}_{2} \mathrm{O}$ content from a bulk analysis (table 5) is added to each electron microprobe analysis, the total weight percent of oxides sums to as much as 105 percent for individual samples. The same problem occurs in the chemical analyses of other zeolites in this report; we suspect that loosely bound $\mathrm{H}_{2} \mathrm{O}$ in the zeolite structure may be driven off by the electron beam, which results in chemical analyses that are slightly high for other elements.

Laboratory studies (Barrer and Sammon, 1955; Mondale and others, 1978; Semmens and Seyfarth, 1978) show that zeolite minerals can be effective in absorbing the same trace elements as are included in table 5. One quantitative trace-element analysis of a chabazite sample collected from an outcrop near the Laurel Hill intrusion (table 5)

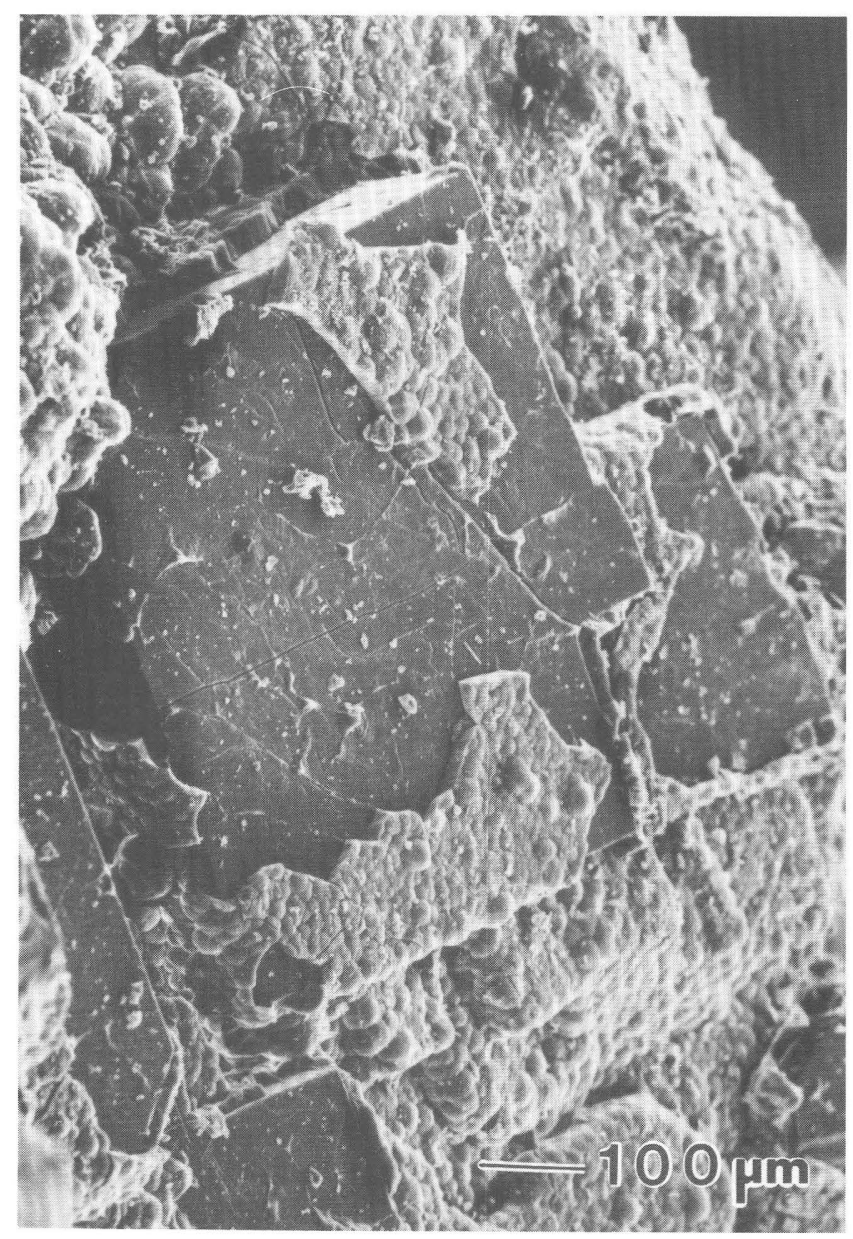

Figure 8. Scanning electron micrograph showing pseudocubic chabazite crystals coated by a thin layer of botryoidal blue-green chrysocolla that has been partially scraped off. Specimen 79LH$0087 \mathrm{H}$ was collected from the contact zone between the Rhododendron Formation and the Laurel Hill intrusion. contains very large amounts of $\mathrm{Sr}$ and $\mathrm{Pb}$, some $\mathrm{Ba}, \mathrm{Cu}$, $\mathrm{Mn}, \mathrm{Ti}, \mathrm{V}$, and $\mathrm{Zn}$, and minor $\mathrm{Co}$ and $\mathrm{Ga}$. X-ray diffraction analysis of this sample also showed minor wairakite contamination; it is not known if the presence of any trace elements should be attributed to this contamination.

\section{EPISTILBITE}

Epistilbite was identified in drill cuttings from four of the Mount Hood drill holes (table 1, Nos. 7, 8, 9, and 13) by Xray diffraction; samples containing epistilbite also were collected in a quarry near the Laurel Hill intrusion. The small amount of epistilbite occurs as vesicle fillings and fracture coatings along with smectite, mixed-layer chlorite-vermiculite(?), wairakite, scolecite, laumontite, hematite, calcite, stilbite, quartz, mordenite, and epidote. Paragenetic relations generally were not observed; however, binocular microscope observations of one fracture surface showed that colorless to white epistilbite formed later than epidote. A sample from $64 \mathrm{~m}$ depth in the Zigzag River drill hole (table 1, No. 8) contains stubby, prismatic epistilbite crystals that are partly coated by smectite (fig. 9).

Several chemical analyses show epistilbite crystals from the Zigzag River drill hole (table 6) to be $\mathrm{Al}$ rich, $\mathrm{Ca}$ rich, and $\mathrm{Si}$ poor compared with published epistilbite analyses (Galli and Rinaldi, 1974; Gottardi and Galli, 1985; Onuki and others, 1988). According to hydrothermal synthesis studies by Lo (1981), the silica content of epistilbite is somewhat variable and depends upon the silica content of the parent material.

\section{FERRIERITE}

One sample of fault gouge from a late Miocene andesite flow, near Barlow Pass at the southern base of Mount Hood, contained colorless, acicular to lamellar crystals of ferrierite in association with smectite (fig. 10). No electron microprobe analysis of the mineral was obtained, but SEM EDS semiquantitative chemical analysis shows the presence of significant $\mathrm{Mg}$ along with $\mathrm{K}, \mathrm{Ca}, \mathrm{Al}$, and $\mathrm{Si}$. Ferrierite is one of the few zeolite minerals that may contain an appreciable amount of magnesium (Gottardi and Galli, 1985).

\section{HARMOTOME}

Harmotome was identified in one sample of an altered andesite flow of the Rhododendron Formation collected from a tailings pile in the deserted Cheeney Creek mining area southwest of Mount Hood. The colorless, blocky harmotome crystals (fig. 11) were deposited later than stellerite(?) on a fracture surface. Other hydrothermal minerals in this sample include chlorite, pyrite, and calcite (altered 
Table 4. Electron-microprobe analyses of chabazite from drill hole and outcrop samples associated with the Laurel Hill intrusion.

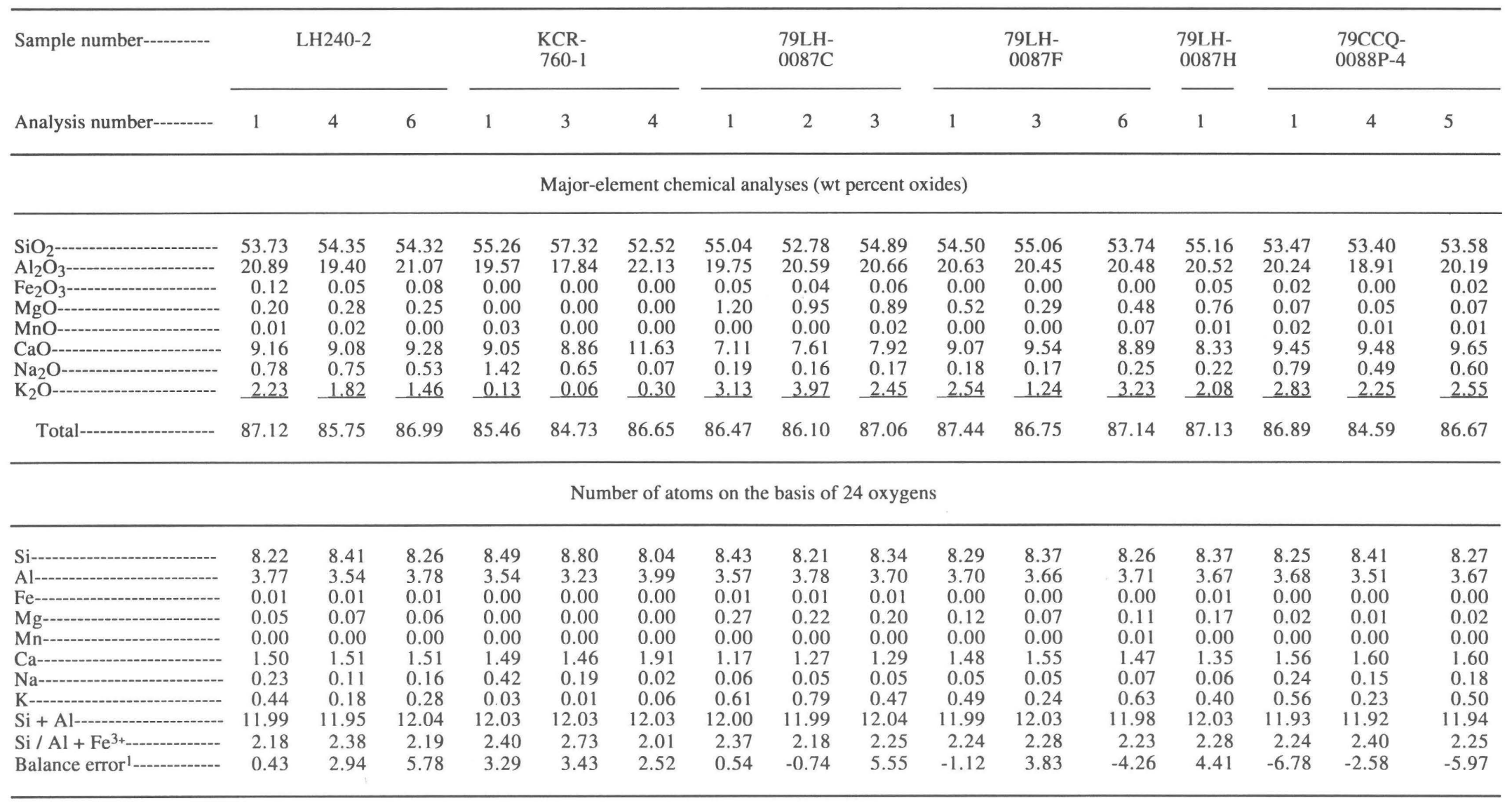

1'Determined by method of Passaglia (1970). 
Table 5. Water-content (in wt percent) and trace-element (in ppm) analyses of selected zeolite minerals from outcrops and drill holes near Mount Hood. [Trace-element analyses for samples 79KLN-0003B, 79CTC-0025, 79CF-0103B, and CF-750-5 are semiquantitative by direct-current arc spectroscopy (analyst: R. Lerner, other analyses are quantitative by inductively coupled plasma-acid digestion (analysts: P.H. Briggs, and J. Cornell). Sample CF-750-5 is from $228.6 \mathrm{~m}$ depth in the Clear Fork drill hole (table I, No. 6); other samples were collected from outcrops near Mount Hood. Dashed(--) where not determined]

\begin{tabular}{|c|c|c|c|c|c|c|c|c|c|c|c|c|c|c|c|}
\hline Mineral & Sample number & $\mathrm{Ba}$ & $\mathrm{Cd}$ & Co & $\mathrm{Cr}$ & $\mathrm{Cu}$ & $\mathrm{Ga}$ & $\mathrm{Mn}$ & $\mathrm{Ni}$ & $\mathrm{Pb}$ & $\mathrm{Sr}$ & $\mathrm{Ti}$ & V & $\mathrm{Zn}$ & $\mathrm{H}_{2} \mathrm{O}^{1}$ \\
\hline Chabazite $^{2}$ & 79LH-0087F & 170 & $<2$ & 2 & $<1$ & 42 & 7 & 230 & $<2$ & 1100 & 7300 & 80 & 21 & 24 & 17.60 \\
\hline Heulandite & $79 \mathrm{CCQ}-0088 \mathrm{C}-1$ & 273 & $<2$ & -- & -- & 9 & -- & 22 & -- & $<4$ & 6500 & -- & -- & $<4$ & 15.93 \\
\hline Laumontite & $79 \mathrm{CCQ}-0088 \mathrm{~B}-1$ & 6 & $<2$ & 2 & $<1$ & 4 & 40 & 14 & 8 & $<4$ & 250 & 100 & 3 & $<4$ & 13.81 \\
\hline Do. & 79KLN-0003B & $<40$ & $<4$ & $<2$ & $<20$ & $<2$ & $<20$ & $<400$ & 2 & $<20$ & 240 & $<400$ & $<20$ & $<100$ & 13.64 \\
\hline Do. & 79СТC-0025 & $<40$ & $<4$ & $<2$ & $<20$ & 280 & 32 & $<400$ & $<2$ & $<20$ & 200 & $<400$ & $<20$ & $<100$ & 13.57 \\
\hline Scolecite & 79CCQ-0088P-4 & 15 & $<2$ & -- & -- & 19 & -- & 43 & -- & $<4$ & 585 & -- & -- & 8 & 14.80 \\
\hline Stilbite & $79 \mathrm{LH}-0087 \mathrm{C}$ & 44 & $<2$ & 1 & 1 & 110 & 5 & 130 & $<2$ & 400 & 210 & 60 & 70 & 180 & 18.76 \\
\hline Do. & 79CCQ-0088D-2 & 9 & 9 & -- & -- & $<1$ & -- & 14 & -- & 9 & 120 & -- & -- & $<4$ & 18.76 \\
\hline Do. & 79CF-0103B & $<40$ & $<4$ & $<2$ & $<20$ & $<2$ & $<20$ & $<400$ & $<2$ & $<20$ & 74 & $<400$ & $<20$ & $<100$ & 18.26 \\
\hline Do. & $79 \mathrm{CCQ}-2001 \mathrm{H}-2$ & 9 & $<2$ & 2 & 6 & 27 & 9 & 38 & 6 & 1400 & 110 & 100 & 3 & 6 & 16.08 \\
\hline Do. & CF-750-5 & $<40$ & $<4$ & $<2$ & $<20$ & $<2$ & $<20$ & $<400$ & $<2$ & $<20$ & $<30$ & $<400$ & $<20$ & $<100$ & 17.94 \\
\hline
\end{tabular}

${ }^{1} \mathrm{H}_{2} \mathrm{O}$ determined by the Karl Fischer titration method (analyst: S.T. Pribble).

2Sample contains minor wairakite contamination. 
plagioclase). Electron-microprobe analyses of these harmotome crystals (table 7) are very high in barium; these analyses plot within or very close to the field of other published harmotome analyses (Cerny' and others, 1977; Robert, 1988) on an exchangeable-cation diagram.

\section{HEULANDITE}

Heulandite occurs in five of the Mount Hood drill holes (table 1, Nos. 3, 5, 8, 10, and 13). Colorless, platy or tabular heulandite crystal fragments were found in only a single sample of late Tertiary quartz diorite drill cuttings from each of drill holes 5, 8, and 10; associated hydrothermal minerals are laumontite, mixed-layer chlorite-smectite, calcite, chlorite, stilbite, epidote, scolecite, magnetite(?), and smectite. Similar colorless, lamellar heulandite crystal fragments from the Pucci Chairlift drill hole (table 1, No. 13) were identified in two samples of late Tertiary volcani-

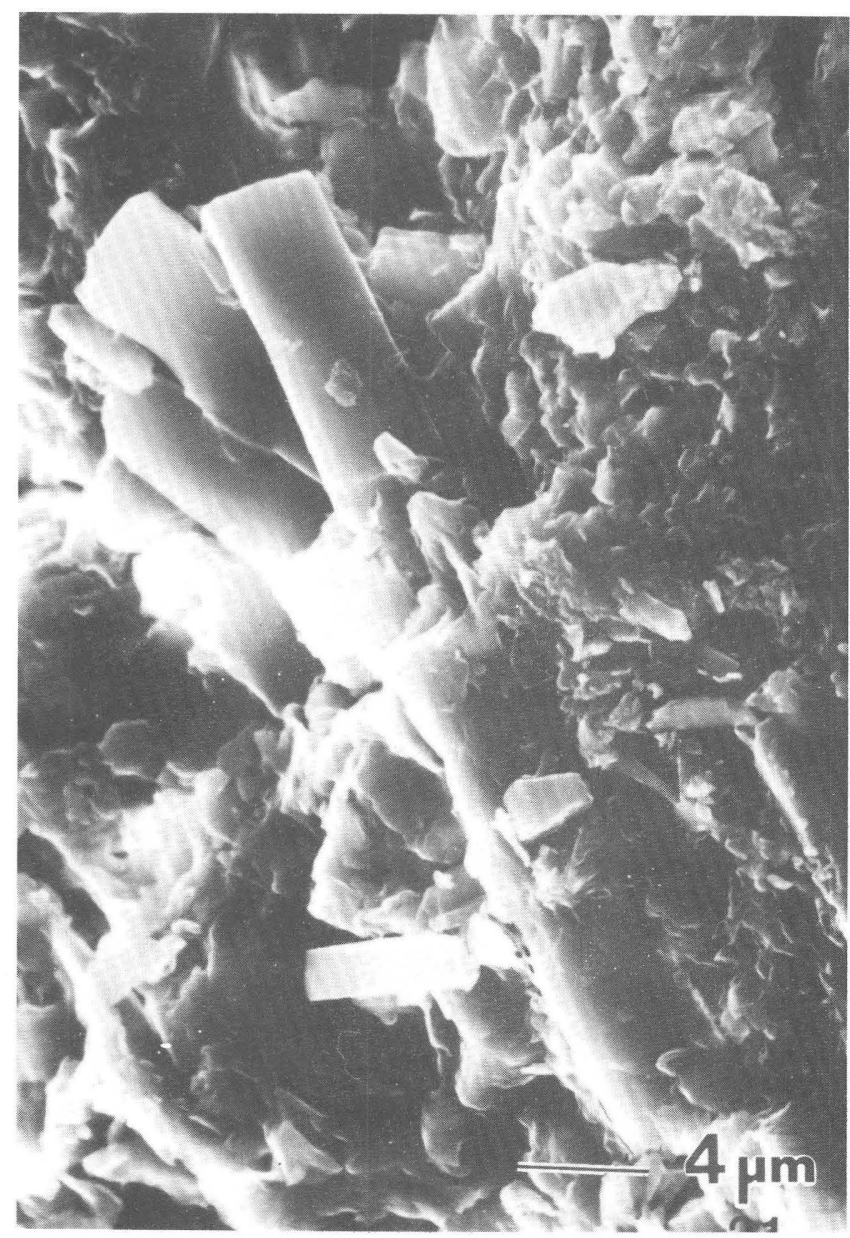

Figure 9. Scanning electron micrograph showing euhedral epistilbite crystals from $64.0 \mathrm{~m}$ depth in the Zigzag River drill hole (table 1, No. 8). Short epistilbite crystals are partially to completely coated by later smectite.
Table 6. Electron-microprobe analyses of epistilbite from the Zigzag River drill hole (table1, No. 8) near Mount Hood.

\begin{tabular}{lrrr}
\hline Sample number----- & \multicolumn{3}{c}{ KCR-210-4 } \\
\cline { 2 - 4 } & & & \\
\cline { 2 - 4 } Analysis number----- & 3 & 4 & 5 \\
\hline
\end{tabular}

\begin{tabular}{crrr} 
Major-element chemical analyses (wt percent oxides) \\
\hline
\end{tabular}

Number of atoms on the basis of 48 oxygens

\begin{tabular}{|c|c|c|c|}
\hline Si--. & 16.22 & 16.23 & 16.15 \\
\hline Al-------... & 7.67 & 7.80 & 7.81 \\
\hline 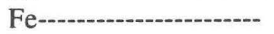 & 0.00 & 0.00 & 0.00 \\
\hline 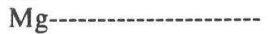 & 0.01 & 0.00 & 0.00 \\
\hline Mn------------------------ & 0.00 & 0.00 & 0.00 \\
\hline 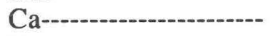 & 3.83 & 3.64 & 3.74 \\
\hline 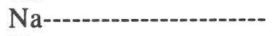 & 0.24 & 0.09 & 0.18 \\
\hline 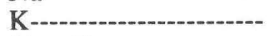 & 0.19 & 0.27 & 0.35 \\
\hline $\mathrm{Si}+\mathrm{Al}$ & 23.89 & 24.04 & 23.95 \\
\hline $\mathrm{Si} / \mathrm{Al}+\mathrm{Fe}^{3+}$ & 2.12 & 2.08 & 2.07 \\
\hline Balance error ${ }^{1}------$ & -5.34 & 1.93 & -2.47 \\
\hline
\end{tabular}

'Determined by method of Passaglia (1970).

clastic debris along with stilbite, chalcedony, and smectite. The McGee Creek drill hole (table 1, No. 3) contains evidence of extensive heulandite deposition in nearly every drill-cuttings sample from both late Tertiary and Quaternary lava flows and volcaniclastic debris intervals between depths of about 50 and $590 \mathrm{~m}$. Colorless heulandite from this drill hole has a blocky habit (fig. 12) in contrast with the tabular habit observed for other Mount Hood samples. The McGee Creek heulandite formed earlier than smectite and calcite in vesicles; other secondary minerals in this drill hole include chalcedony, rhodochrosite, manganese calcite, dolomite, pyrite, spinel(?), alunite, and hematite.

Heulandite was identified, along with celadonite, mordenite, smectite, and B-cristobalite, in one sample of highly altered volcanogenic rocks of the Rhododendron Formation that crops out about $10 \mathrm{~km}$ west-northwest of Mount Hood. Colorless, tabular heulandite crystals (max. $0.5 \mathrm{~cm}$ across) occur in several samples of an altered Rhododendron lava flow that was intruded by the Laurel Hill intrusion. The heulandite formed as late-stage fracture fillings 
along with several other hydrothermal minerals (chrysocolla, chlorite, magnetite, smectite, epidote, laumontite, actinolite, hematite, quartz, chabazite, and stellerite(?)).

Samples were identified as heulandite by X-ray diffraction analysis, which included heating the sample overnight at $450^{\circ} \mathrm{C}$ (Mumpton, 1960). In X-ray diffraction analyses of these heated samples, the (020) X-ray reflection at $\sim 9 \AA$ was destroyed, indicating the presence of heulandite rather than another member of the heulandite group of zeolites (Mumpton, 1960). Heulandite is further distinguished from other heulandite-group minerals by having $\mathrm{Ca}>\mathrm{Na}+\mathrm{K}$ (Mason and Sand, 1960). Several electron-microprobe analyses (table 8 ) of one heulandite sample from volcaniclastic rocks of the Rhododendron Formation near the Laurel Hill intrusion clearly indicate that $\mathrm{Ca}$ is the predominant exchangeable cation and that the mineral is heulandite. Adding the $\mathrm{H}_{2} \mathrm{O}$ content (table 5) of this heulandite sample to

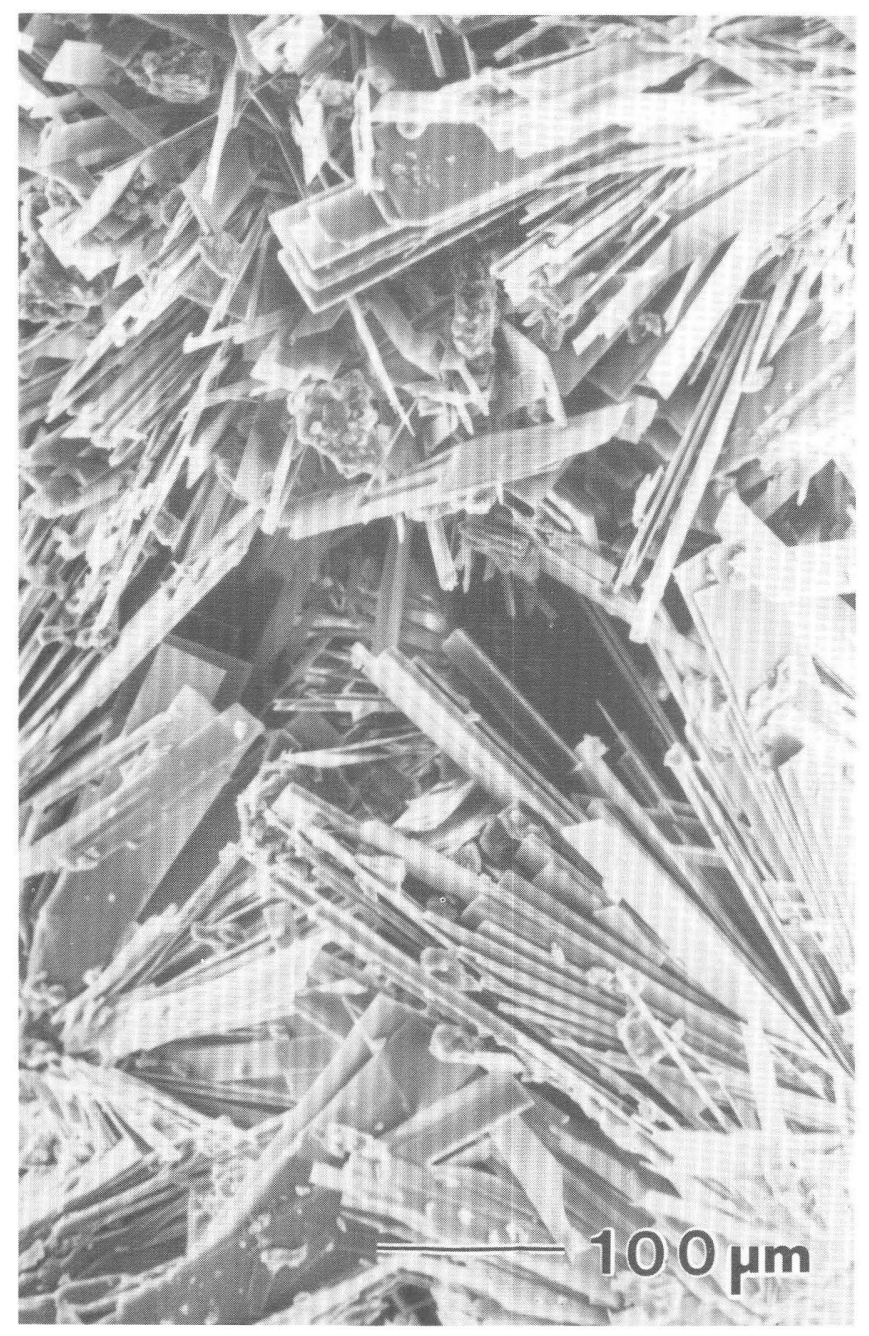

Figure 10. Scanning electron micrograph showing lamellar crystals and prismatic needles of ferrierite (mordenite group) from an outcrop near Barlow Pass on the south side of Mount Hood. the electron-microprobe analyses' total weight percent oxides (table 8) indicates that some $\mathrm{H}_{2} \mathrm{O}$ is released owing to heat generated by the electron beam. A quantitative traceelement chemical analyses of this heulandite sample shows the presence of $\mathrm{Ba}, \mathrm{Cu}, \mathrm{Mn}$, and significant $\mathrm{Sr}$ (table 5). Abundant $\mathrm{SrO}$ (7.9 weight percent) and $\mathrm{BaO}$ (5.6 weight percent) have been previously reported for heulandite by Lucchetti and others (1982) and Miller and Ghent (1973), respectively.

Most heulandite found in late Tertiary volcanic rocks near Mount Hood consists of colorless, lamellar or tabular crystals similar to the typical morphology reported in Gottardi and Galli (1985). Conversely, ubiquitous heulandite open-space fillings in the McGee Creek drill hole have a colorless, blocky habit and occur in drill cuttings from both late Tertiary and Quaternary volcanogenic rocks. The blocky heulandite crystals found in volcanic rocks of both time intervals probably were deposited late in the geologic history of Mount Hood and may have precipitated from still-ongoing processes. The maximum temperature record-

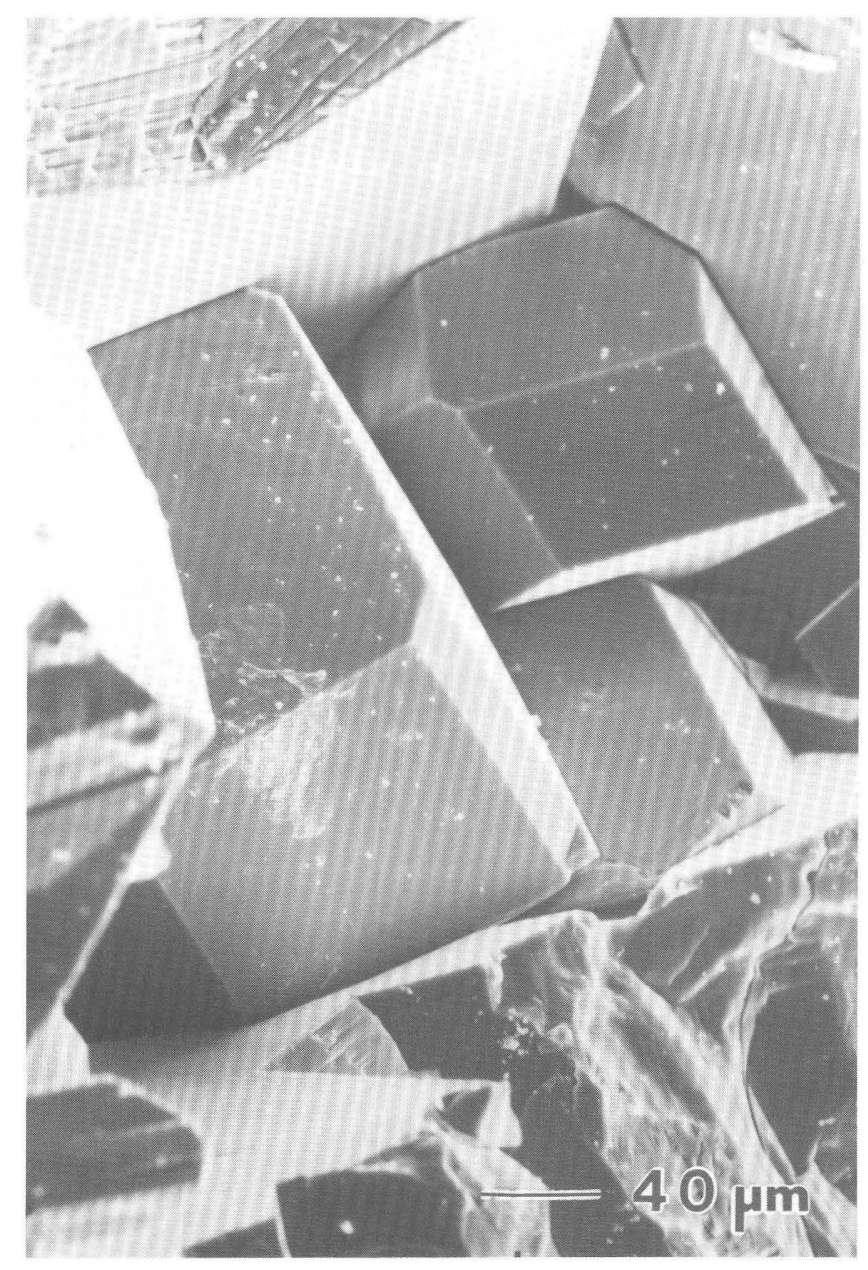

Figure 11. Scanning electron micrograph showing harmotome (phillipsite group) crystals from the abandoned Cheeney Creek Mining Area, southwest of Mount Hood. 
Table 7. Electron-microprobe analyses of harmotome from the Cheeney Creek area, southwest of Mount Hood.

\begin{tabular}{lrrr}
\hline \multirow{2}{*}{ Sample number------ } & \multicolumn{3}{c}{ 79BM-2046I } \\
\cline { 2 - 4 } Analysis number----- & \multicolumn{1}{c}{2} & \multicolumn{1}{c}{3} & 9 \\
\hline & & & \\
\hline & & & \\
Major-element chemical analyses (wt percent oxides) \\
\hline
\end{tabular}

Number of atoms on the basis of 32 oxygens

\begin{tabular}{|c|c|c|c|}
\hline Si-- & 10.93 & 11.19 & 11.10 \\
\hline Al---- & 5.09 & 4.88 & 4.92 \\
\hline $\mathrm{Fe}----$ & 0.00 & 0.00 & 0.00 \\
\hline 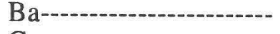 & 1.83 & 1.87 & 1.98 \\
\hline $\mathrm{Ca}---1-1-1$ & 0.35 & 0.13 & 0.10 \\
\hline 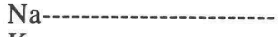 & 0.30 & 0.32 & 0.27 \\
\hline K---:- & 0.37 & 0.29 & 0.37 \\
\hline $\mathrm{Si}+\mathrm{Al}-\mathrm{-}$ & 16.02 & 16.07 & 16.03 \\
\hline $\mathrm{Si} / \mathrm{Al}+\mathrm{Fe}^{3+}$ & 2.15 & 2.29 & 2.26 \\
\hline Balance error ${ }^{1}---------$ & 1.52 & 6.18 & 2.22 \\
\hline
\end{tabular}

'Determined by method of Passaglia (1970).

ed near the bottom of the McGee Creek drill hole was $60^{\circ} \mathrm{C}$ (Robison and others, 1982). Heulandite from Icelandic geothermal areas has been reported by Kristmannsdóttir and Tómasson (1978) to exist at temperatures somewhat lower than $70^{\circ} \mathrm{C}$.

\section{LAUMONTITE}

Laumontite occurs in numerous samples of drill cuttings from six Mount Hood drill holes (table 1, Nos. 5, 6, 7, 8, 10, and 13). Drill-hole samples of lavas from the Columbia River Basalt Group, lava flows and volcaniclastic units of the Rhododendron Formation, early Tertiary andesites, and the Laurel Hill and Still Creek intrusions all contain extensive laumontite deposits. Laumontite is notably absent from late Tertiary andesites and Quaternary volcanogenic rocks near Mount Hood. In drill-hole cuttings samples, laumontite commonly is found as open-space (fracture, vug, or cavities between breccia fragments) fillings and consists of intergrown euhedral crystals (fig. 13). Other hydrothermal minerals identified in the laumontite-bearing drill cuttings include hematite, goethite, pyrite, smectite, illite, chlorite, quartz, chalcedony, calcite, chabazite, stilbite, heulandite, prehnite, mordenite, native copper, epistilbite, stellerite(?), scolecite, chalcopyrite, epidote, wairakite, and magnetite.

Laumontite was found in several outcrop samples of the Rhododendron Formation that appear to be altered because of later emplacement of the Laurel Hill and Still Creek intrusions; laumontite also occurs in association with a late Tertiary hornblende andesite intrusive plug on the south side of Zigzag Mountain. These laumontite deposits line fractures and vugs, fill open spaces between breccia fragments, and replace(?) plagioclase phenocrysts. The outcrop samples also contain many of the associated hydrothermal minerals identified in the drill-hole samples. Observed paragenetic relationships suggest that chlorite, epidote, and quartz formed earlier than laumontite and calcite is a later deposit.

Electron-microprobe analyses of laumontite from two outcrop samples collected from altered rocks of the Rhododendron Formation near the Laurel Hill intrusion show that $\mathrm{Ca}$ is the dominant exchangeable cation and that the samples contain very little $\mathrm{Na}$ and only minor K (table 9). Holdaway and Bussey (1982) reported similar chemical compositions

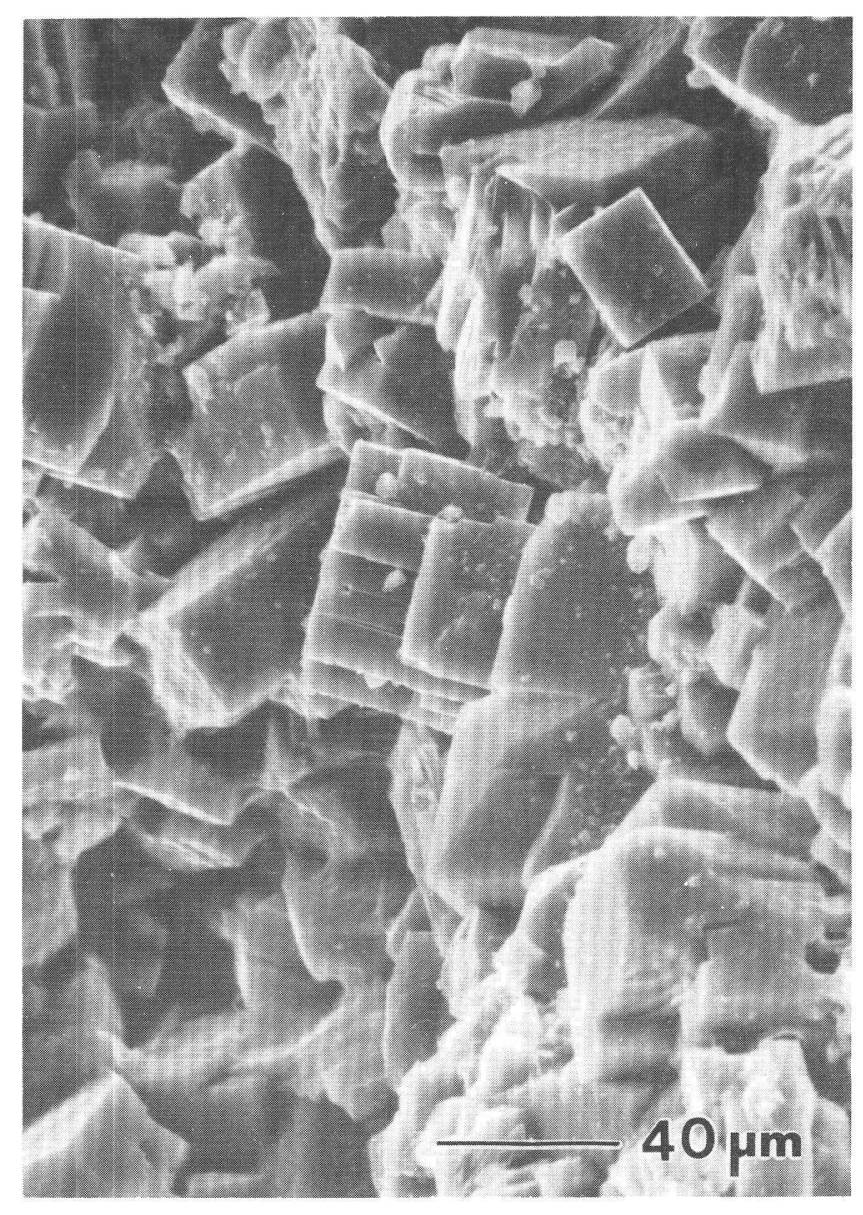

Figure 12. Scanning electron micrograph showing blocky heulandite crystals from $64.0 \mathrm{~m}$ depth in the McGee Creek drill hole. Some crystals appear to be partly coated by later smectite. 
Table 8. Electron-microprobe analyses of heulandite from a fracture filling in a lava flow of the Rhododendron Formation altered by the Laurel Hill intrusion.

\begin{tabular}{llll}
\hline Sample number----- & \multicolumn{3}{c}{ 79CCQ-0088C-1 } \\
\cline { 2 - 3 } & 2 & 4 & 7 \\
\hline
\end{tabular}

Major-element chemical analyses (wt percent oxides)

\begin{tabular}{|c|c|c|c|}
\hline $\mathrm{SiO}_{2}$ & 59.49 & 58.42 & 58.74 \\
\hline $\mathrm{Al}_{2} \mathrm{O}_{3}$ & 17.76 & 17.83 & 17.57 \\
\hline $\mathrm{Fe}_{2} \mathrm{O}_{3}$ & 0.04 & 0.01 & 0.02 \\
\hline 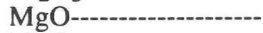 & 0.04 & 0.03 & 0.03 \\
\hline MnO------------------ & 0.00 & 0.00 & 0.02 \\
\hline $\mathrm{CaO}$ & 8.91 & 8.74 & 8.71 \\
\hline $\mathrm{Na}_{2} \mathrm{O}$ & 0.57 & 0.83 & 0.52 \\
\hline $\mathrm{K}_{2} \mathrm{O}$ & 0.23 & 0.27 & 0.18 \\
\hline Total------------- & 87.04 & 86.13 & 85.79 \\
\hline
\end{tabular}

Number of atoms on the basis of 72 oxygens

\begin{tabular}{|c|c|c|c|}
\hline ----------------- & 26.65 & 26.49 & 26.67 \\
\hline Al------------------------ & 9.38 & 9.53 & 9.40 \\
\hline $\mathrm{Fe}---$ & 0.01 & 0.00 & 0.01 \\
\hline Mg----------------------- & 0.03 & 0.02 & 0.02 \\
\hline 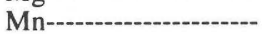 & 0.00 & 0.00 & 0.01 \\
\hline Ca------_-------------- & 4.28 & 4.25 & 4.24 \\
\hline 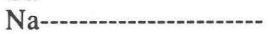 & 0.49 & 0.73 & 0.45 \\
\hline 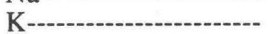 & 0.13 & 0.15 & 0.10 \\
\hline $\mathrm{Si}+\mathrm{Al}-\mathrm{-}$ & 36.03 & 36.03 & 36.07 \\
\hline $\mathrm{Si} / \mathrm{Al}+\mathrm{Fe}^{3+}$ & 2.84 & 2.78 & 2.83 \\
\hline Balance error 1 & 1.71 & 1.32 & 3.63 \\
\hline
\end{tabular}

${ }^{1}$ Determined by method of Passaglia (1970).

for laumontite from drill hole OMF-7A, on the northwest side of Mount Hood; however, their laumontite chemical analyses contain more $\mathrm{Na}_{2} \mathrm{O}$ than $\mathrm{K}_{2} \mathrm{O}$ and they also reported minor $\mathrm{BaO}$ in one analysis. One quantitative trace-element chemical analysis (table 5, 79CCQ-0088B-1) of laumontite from near the Laurel Hill intrusion contained measurable amounts of $\mathrm{Sr}, \mathrm{Ti}$, and $\mathrm{Ga}$ and traces of $\mathrm{Ba}, \mathrm{Co}$, $\mathrm{Cu}, \mathrm{Mn}, \mathrm{Ni}$, and $\mathrm{V}$. Also, some $\mathrm{Cu}, \mathrm{Ga}$, and $\mathrm{Sr}$, along with minor $\mathrm{Ni}$, was found by semiquantitative trace-element chemical analyses of two laumontite samples collected from Zigzag Mountain and from propylitically altered rocks associated with the Still Creek intrusion (Wise, 1969) southwest of Mount Hood. Analysis of $\mathrm{H}_{2} \mathrm{O}$ in one laumontite sample (table 5, 79CCQ-0088B-1) that was also analyzed by electron microprobe is ambiguous in that the analysis totals, with $\mathrm{H}_{2} \mathrm{O}$ added, range from $\sim 97$ to $\sim 103$ percent.

\section{MORDENITE}

White, fibrous mordenite was identified in drill cuttings from three of the Mount Hood drill holes (table 1, Nos. 2,
6, and 13). In the Clear Branch drill hole, mordenite occurs in early Tertiary lava flows and volcaniclastic debris units between 201 and $210 \mathrm{~m}$ depth and from depths of 250 to $293 \mathrm{~m}$ along with alunite, smectite, pyrite, opal, calcite, and B-cristobalite. Volcaniclastic drill-cuttings samples of the Rhododendron Formation from depths of 253 and $268 \mathrm{~m}$ in the Clear Fork drill hole contain mordenite as well as smectite, hematite, calcite, stilbite, and laumontite. Early Tertiary lava flows and volcaniclastic intervals in the Pucci Chairlift drill hole have numerous mordenite-bearing samples between depths of 896 and $1,167 \mathrm{~m}$; other hydrothermal minerals in this drill hole include chalcedony, smectite, calcite, laumontite, stilbite, and epistilbite.

One sample from a volcaniclastic outcrop of the Rhododendron Formation northwest of Mount Hood contains white, fibrous mordenite along with heulandite, smectite, and celadonite. Two outcrops of early Tertiary rocks southeast of Mount Hood have vesicle fillings and open spaces between breccia fragments that are filled by

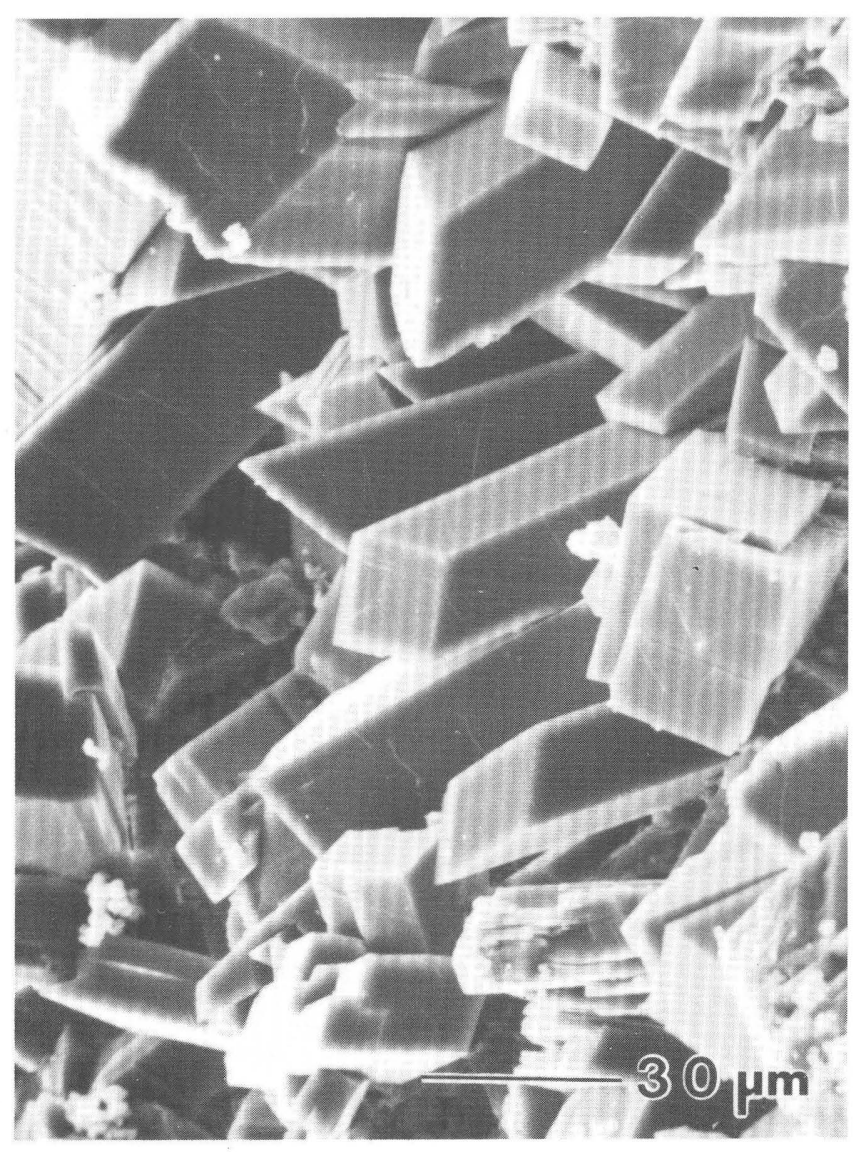

Figure 13. Scanning electron micrograph showing open-space filling of euhedral laumontite prismatic crystals from about 1,128 $\mathrm{m}$ depth in the Pucci Chairlift drill hole. Distinctive terminal ends of the laumontite crystals permit easy identification of the mineral. 
Table 9. Electron-microprobe analyses of laumontite from fractures in volcanic rocks of the Rhododendron Formation altered by the Laurel Hill intrusion.

\begin{tabular}{llllllll}
\hline \multirow{2}{*}{ Sample number------ } & \multicolumn{3}{c}{ 79LH-0087D } & & \multicolumn{3}{c}{ 79CCQ-0088B } \\
\cline { 2 - 4 } \cline { 5 - 6 } & & 2 & 3 & & 2 & 5 & 6 \\
\hline
\end{tabular}

Major-element chemical analyses (wt percent oxides)

\begin{tabular}{|c|c|c|c|c|c|c|}
\hline $\mathrm{SiO}_{2-}$ & 53.11 & 53.42 & 52.51 & 50.84 & 53.65 & 52.74 \\
\hline $\mathrm{Al}_{2} \mathrm{O}_{3}$ & 21.56 & 22.49 & 21.06 & 21.16 & 22.28 & 22.04 \\
\hline $\mathrm{Fe}_{2} \mathrm{O}_{3}$ & 0.00 & 0.05 & 0.01 & 0.00 & 0.03 & 0.06 \\
\hline 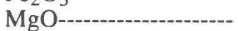 & 0.04 & 0.02 & 0.05 & 0.03 & 0.03 & 0.03 \\
\hline MnO-- & 0.02 & 0.02 & 0.02 & 0.00 & 0.00 & 0.01 \\
\hline $\mathrm{CaO}$ & 11.39 & 11.69 & 11.25 & 10.78 & 11.86 & 11.34 \\
\hline $\mathrm{Na}_{2} \mathrm{O}$ & 0.05 & 0.07 & 0.05 & 0.07 & 0.06 & 0.06 \\
\hline $\mathrm{K}_{2} \mathrm{O}$ & $\underline{0.64}$ & 0.67 & 0.73 & 0.51 & 0.44 & 0.56 \\
\hline - & 86.81 & 88.43 & 85.68 & 83.39 & 88.35 & 6.84 \\
\hline
\end{tabular}

Number of atoms on the basis of 48 oxygens

\begin{tabular}{|c|c|c|c|c|c|c|}
\hline $\mathrm{Si}-\ldots$ & 16.23 & 16.05 & 16.27 & 16.15 & 16.11 & 16.11 \\
\hline $\mathrm{Al}--$ & 7.77 & 7.97 & 7.69 & 7.93 & 7.89 & 7.94 \\
\hline Fe--1- & 0.00 & 0.01 & 0.00 & 0.00 & 0.01 & 0.01 \\
\hline Mg-.....-. & 0.02 & 0.01 & 0.02 & 0.01 & 0.01 & 0.01 \\
\hline $\mathrm{Mn}-$ & 0.01 & 0.01 & 0.01 & 0.00 & 0.00 & 0.00 \\
\hline $\mathrm{Ca}--$ & 3.73 & 3.77 & 3.73 & 3.67 & 3.82 & 3.71 \\
\hline $\mathrm{Na}--$ & 0.03 & 0.04 & 0.03 & 0.04 & 0.03 & 0.03 \\
\hline 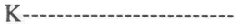 & 0.25 & 0.26 & 0.29 & 0.21 & 0.17 & 0.22 \\
\hline $\mathrm{Si}+\mathrm{Al}-$ & 24.00 & 24.02 & 23.96 & 24.08 & 24.00 & 24.05 \\
\hline $\mathrm{Si} / \mathrm{Al}+\mathrm{Fe}^{3+}$ & 2.09 & 2.02 & 2.12 & 2.04 & 2.04 & 2.03 \\
\hline Balance error ${ }^{1}--\cdot-$ & -0.28 & 1.57 & -1.85 & 4.09 & 0.46 & 3.13 \\
\hline
\end{tabular}

${ }^{1}$ Determined by method of Passaglia (1970).

mordenite associated with quartz, calcite, and chlorite. Tiny mordenite fibers are difficult to analyze using an electron microprobe and no quantitative chemical analyses were obtained; however, $\mathrm{Ca}, \mathrm{Na}($ ?), $\mathrm{Al}$, and $\mathrm{Si}$ were detected in a sample from the Pucci Chairlift drill hole by qualitative analysis using the EDS capability of an SEM.

\section{SCOLECITE}

Although scolecite is a common hydrothermal mineral (Gottardi and Galli, 1985), it does not appear to be very abundant in hydrothermally altered rocks from the Mount Hood area. Bundles of white, radiating, fibrous scolecite crystals occur in small amounts in quartz diorite drill cuttings from two Mount Hood drill holes (table 1, Nos. 8 and 10). Vein deposits of white, acicular, scolecite crystals (fig. 14) also were found in four volcanic rock samples of the Rhododendron Formation from near the Laurel Hill intrusion. Other hydrothermal minerals identified in these samples include quartz, laumontite, stellerite(?), chlorite, epidote, pyrite, calcite, wairakite, smectite, chabazite, chalcopyrite, actinolite(?), and magnetite(?). The only minerals observed in association with scolecite by SEM are stellerite(?) and smectite. Presumably, scolecite formed late in the sequence of alteration minerals; scolecite is reported to occur in low-temperature geothermal areas of Iceland at temperatures below $100^{\circ} \mathrm{C}$ (Kristmannsdóttir and Tómasson, 1978).

Several electron-microprobe analyses of scolecite from four samples near Mount Hood (table 10) show that the mineral is nearly homogeneous. The chemical composition of Mount Hood scolecite is very near the stoichiometric formula for scolecite, consisting predominantly of $\mathrm{Ca}, \mathrm{Al}$, and $\mathrm{Si}$ along with minor $\mathrm{Na}$ and little or no $\mathrm{K}, \mathrm{Mg}, \mathrm{Fe}$, or Mn. A quantitative trace-element analysis of one sample (table 5) also showed the presence of minute amounts of $\mathrm{Ba}, \mathrm{Cu}$, and $\mathrm{Zn}$, as well as significant $\mathrm{Sr}$. Adding $\mathrm{H}_{2} \mathrm{O}$ content (table 5) to each electron-microprobe analyses' weight percent oxides results in totals near 100 percent, which indicates that $\mathrm{H}_{2} \mathrm{O}$ and, presumably $\mathrm{Na}$ and $\mathrm{K}$ as well, are held fairly tightly within the scolecite crystal structure.

\section{STILBITE AND STELLERITE(?)}

Stilbite is a fairly common zeolite mineral in the Mount Hood area; several outcrop samples (near the Laurel Hill intrusion) and drill-hole-cuttings samples (table 1, Nos. 4, $5,6,7,9,10$, and 13) contain soft, white fragments; colorless, broken crystals; or euhedral, tabular crystals of stilbite (fig. 15). Colorless or white grains and crystals of stellerite(?) (our identification is tentative) were found only in drill cuttings from several depths in the Zigzag River drill hole (table 1, No. 8) and in one sample from a

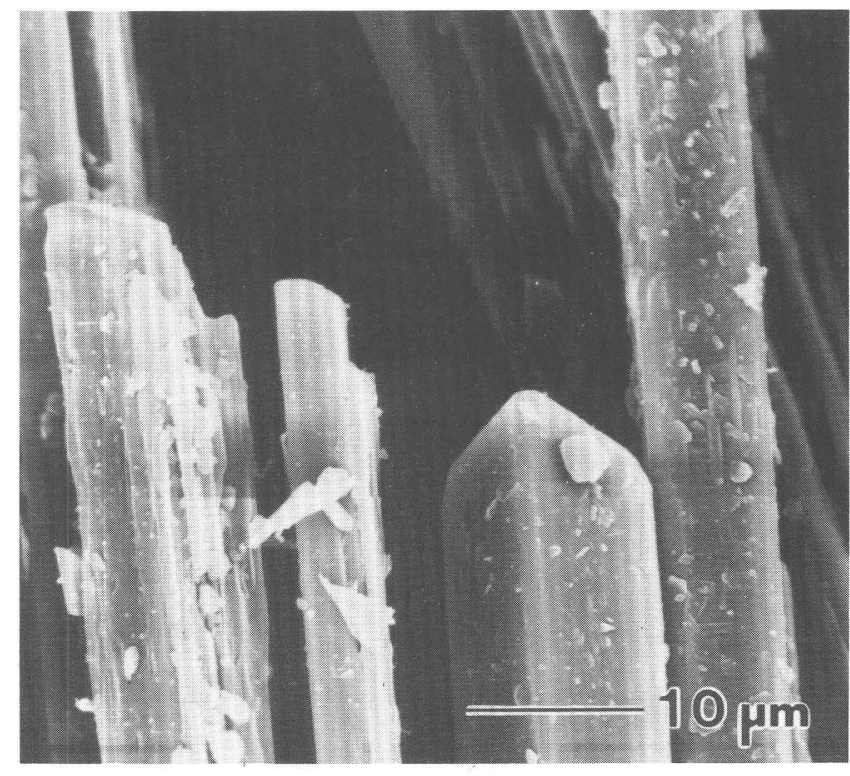

Figure 14. Scanning electron micrograph showing euhedral, acicular scolecite crystals from a fracture filling in a lava flow of the Rhododendron Formation that was intruded by the Laurel Hill intrusion. 
Table 10. Electron-microprobe analyses of scolecite from outcrops and drill holes near Mount Hood.

\begin{tabular}{|c|c|c|c|c|c|c|c|c|c|c|c|}
\hline \multirow{2}{*}{$\begin{array}{l}\text { Sample number-------- } \\
\text { Analysis number---.--- }\end{array}$} & \multicolumn{3}{|c|}{ 79CCQ-0088P-41 } & \multicolumn{3}{|c|}{ 79-CCQ-2001H-4 } & \multicolumn{3}{|c|}{ KCR-360-4 } & \multicolumn{2}{|c|}{ 79IC-2032 } \\
\hline & 1 & 6 & 10 & 1 & 2 & 3 & 2 & 4 & 5 & 1 & 2 \\
\hline \multicolumn{12}{|c|}{ Major-element chemical analyses (wt percent oxides) } \\
\hline $\mathrm{SiO}_{2}$ & 45.96 & 45.37 & 45.24 & 44.68 & 44.59 & 44.63 & 45.64 & 45.07 & 44.52 & 45.21 & 45.89 \\
\hline $\mathrm{Al}_{2} \mathrm{O}_{3}$ & 25.06 & 25.36 & 25.64 & 24.49 & 25.14 & 25.37 & 25.89 & 24.95 & 24.48 & 24.97 & 24.59 \\
\hline $\mathrm{Fe}_{2} \mathrm{O}_{3}$ & 0.00 & 0.02 & 0.02 & 0.03 & 0.06 & 0.00 & 0.01 & 0.00 & 0.00 & 0.04 & 0.01 \\
\hline MgO--1-1- & 0.01 & 0.04 & 0.03 & 0.03 & 0.01 & 0.01 & 0.01 & 0.03 & 0.01 & 0.01 & 0.00 \\
\hline MnO----------------------- & 0.00 & 0.00 & 0.02 & 0.00 & 0.00 & 0.00 & 0.00 & 0.00 & 0.00 & 0.00 & 0.00 \\
\hline $\mathrm{CaO}-$ & 14.25 & 13.81 & 13.44 & 13.99 & 13.76 & 13.84 & 13.87 & 13.21 & 13.53 & 13.95 & 13.97 \\
\hline $\mathrm{Na}_{2} \mathrm{O}$ & 0.23 & 0.25 & 0.29 & 0.10 & 0.13 & 0.16 & 0.15 & 0.47 & 0.26 & 0.14 & 0.23 \\
\hline $\mathrm{K}_{2} \mathrm{O}$ & $\underline{0.01}$ & $\underline{0.00}$ & $\underline{0.02}$ & $\underline{0.00}$ & $\underline{0.00}$ & $\underline{0.00}$ & $\underline{0.01}$ & $\underline{0.00}$ & $\underline{0.01}$ & $\underline{0.00}$ & $\underline{0.00}$ \\
\hline Total---------------- & 85.52 & 84.85 & 84.70 & 83.32 & 83.69 & 84.01 & 85.58 & 83.73 & 82.81 & 84.32 & 84.69 \\
\hline
\end{tabular}

Number of atoms on the basis of 80 oxygens

\begin{tabular}{|c|c|c|c|c|c|c|c|c|c|c|c|}
\hline 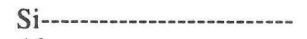 & 24.23 & 24.09 & 24.04 & 24.18 & 24.01 & 23.95 & 24.01 & 24.21 & 24.22 & 24.16 & 24.40 \\
\hline Al------.. & 15.57 & 15.87 & 16.06 & 15.62 & 15.96 & 16.04 & 16.05 & 15.80 & 15.70 & 15.73 & 15.41 \\
\hline Fe--------------------------- & 0.00 & 0.01 & 0.00 & 0.01 & 0.03 & 0.00 & 0.00 & 0.00 & 0.00 & 0.01 & 0.01 \\
\hline 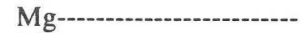 & 0.01 & 0.03 & 0.02 & 0.02 & 0.01 & 0.00 & 0.00 & 0.02 & 0.00 & 0.00 & 0.00 \\
\hline 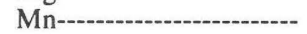 & 0.00 & 0.00 & 0.01 & 0.00 & 0.00 & 0.00 & 0.00 & 0.00 & 0.00 & 0.00 & 0.00 \\
\hline 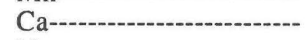 & 8.05 & 7.85 & 7.65 & 8.11 & 7.94 & 7.95 & 7.82 & 7.61 & 7.88 & 7.99 & 7.96 \\
\hline 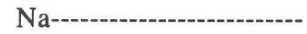 & 0.24 & 0.25 & 0.30 & 0.11 & 0.14 & 0.16 & 0.16 & 0.49 & 0.27 & 0.15 & 0.23 \\
\hline 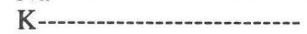 & 0.00 & 0.00 & 0.01 & 0.00 & 0.00 & 0.00 & 0.01 & 0.00 & 0.01 & 0.00 & 0.00 \\
\hline $\mathrm{Si}+\mathrm{Al}$ & 39.80 & 39.96 & 40.09 & 39.80 & 39.96 & 39.99 & 40.06 & 40.01 & 39.91 & 39.89 & 39.81 \\
\hline $\mathrm{Si} / \mathrm{Al}+\mathrm{Fe}^{3+}$ & 1.56 & 1.52 & 1.50 & 1.55 & 1.50 & 1.49 & 1.50 & 1.53 & 1.54 & 1.53 & 1.58 \\
\hline Balance error²----a-- & -4.75 & -0.89 & 2.46 & -4.58 & -0.33 & -0.21 & 1.52 & 0.31 & -2.23 & -2.41 & -4.55 \\
\hline
\end{tabular}

\footnotetext{
${ }^{1}$ Quantitative trace-element chemical analysis by optical spectroscopy (table 5) shows the presence of $43 \mathrm{ppm} \mathrm{Mn}, 15 \mathrm{ppm}$ $\mathrm{Ba}, 19 \mathrm{ppm} \mathrm{Cu}, 585 \mathrm{ppm} \mathrm{Sr}$, and $8 \mathrm{ppm} \mathrm{Zn}$.

${ }^{2}$ Determined by method of Passaglia (1970).
}

quarry containing volcanic rocks of the Rhododendron Formation intruded by the Laurel Hill intrusion. Stilbite and stellerite(?) minerals occur in vesicles and as vein or fracture fillings in late Miocene volcanic rocks. Other minerals identified in the same samples include calcite, siderite, chabazite, epistilbite, heulandite, laumontite, mordenite, scolecite, wairakite, opal, quartz, chalcedony, smecite, chlorite, illite, mixed-layer chlorite-smectite, celadonite, hematite, goethite, magnetite, pyrite, native copper, chrysocolla, palagonite, prehnite, actinolite, epidote, and adularia.

Stellerite is chemically and structurally similar to stilbite and the two minerals are difficult to distinguish by routine methods. Some differences occur in the common crystal morphology of these minerals (Gottardi and Galli, 1985): Most euhedral, tabular stilbite crystals are twinned and have pyramidal terminations (fig. 15), whereas orthorhombic stellerite crystals are rectangular and have very prominent $\{001\}$ terminations (fig. 16). Galli and Passaglia (1973) indicated that stellerite and stilbite could be identified optically by differences in their extinction angles. Lack of double X-ray diffraction reflections between $23^{\circ}$ and $24^{\circ}$ $2 \theta$ is characteristic of stellerite. Chemical differences have also been used to differentiate the two minerals because stellerite usually is higher in $\mathrm{Si}$ and lower in $\mathrm{Na}$ than stilbite (Galli and Passaglia, 1973; Passaglia and others, 1978). Unfortunately, while differences in crystal morphology are generally indicative of these minerals, this criteria is not 100 percent reliable because many morphological variations can occur. Identification of stellerite and stilbite from their optical properties is difficult; stellerite has parallel extinction and extinction of stilbite crystals may be extremely close to parallel (Passaglia and Pongiluppi, 1974); this is true for samples from the Mount Hood area. Also, chemical differences between stilbite and stellerite are not unequivocally distinct because there is a complete compositional series between the two minerals (Passaglia and others, 1978). The only method of unambiguous identification of stilbite and stellerite is by a single-crystal X-ray diffraction study (R.C. Erd, written commun., 1992).

Because single-crystal X-ray analysis would be impractical for the multitude of mineral identifications required 
in this study, crystal morphologies, routine X-ray diffraction analyses, and mineral chemistries were relied upon for stilbite-stellerite mineral identifications. Most stilbitestellerite crystals from the Mount Hood area appear to have crystal morphologies and $\mathrm{X}$-ray diffraction reflections characteristic of stilbite; these characteristics are compatible with stellerite in only a few studied samples. However, some electron-microprobe analyses of stilbite crystals show about the same low $\mathrm{Na}$ and high $\mathrm{Si}$ contents as stellerite analyses (tables 11 and 12). Passaglia and Pongiluppi (1974) showed that the $\mathrm{Si} / \mathrm{Si}+\mathrm{Al}+\mathrm{Fe}$ ratio should be about 0.77 for stellerite and about 0.72 for stilbite; although, in a later study, Passaglia and others (1978) showed that the two minerals form a continuous series. The Mount Hood stilbite and stellerite(?) crystals appear to lie in the middle of this compositional series, with (1) $\mathrm{Si} / \mathrm{Si}+\mathrm{Al}+\mathrm{Fe}$ ratios ranging from 0.73 to 0.77 (tables 11 and 12), (2) pseudo-orthorhombic(?) crystallinity as suggested by nearly parallel extinction angles for stilbite, and (3) similar $\mathrm{Si}$ and $\mathrm{Na}$ contents.

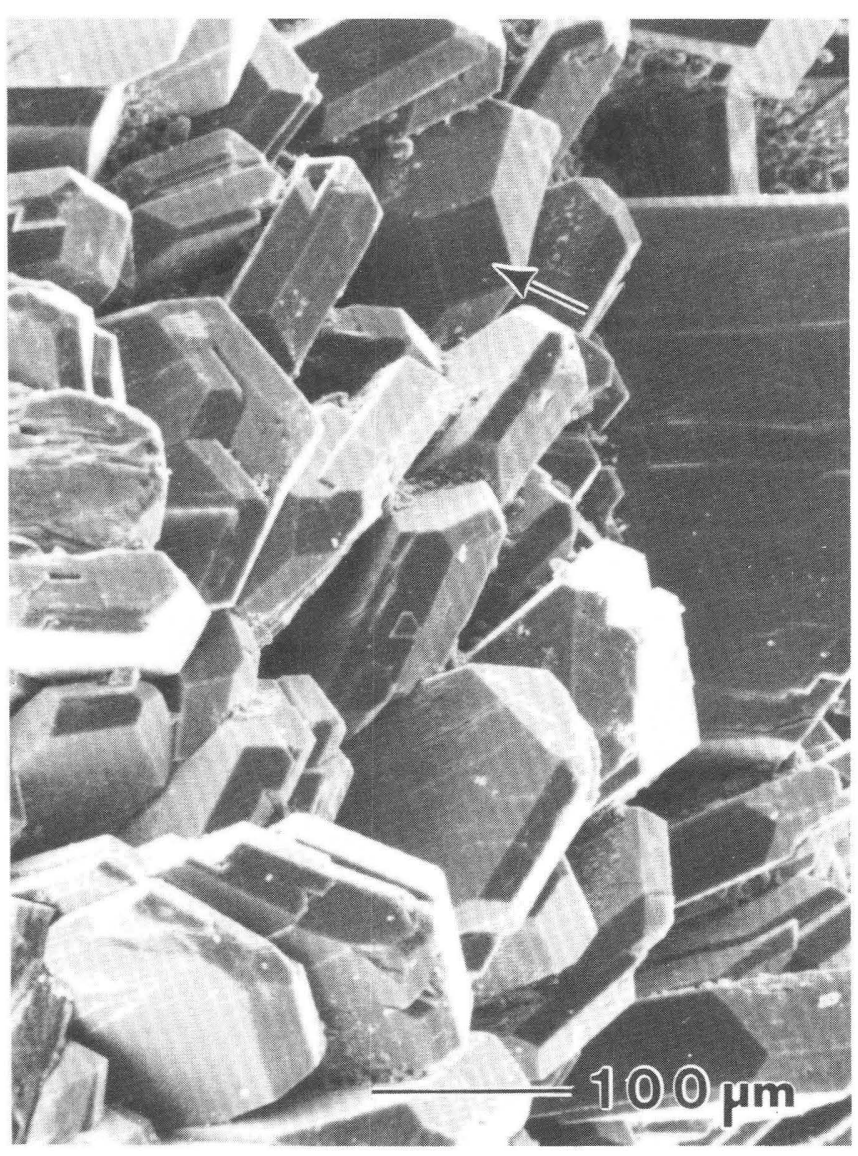

Figure 15. Scanning electron micrograph showing euhedral, tabular stilbite crystals in drill cuttings from $\sim 884 \mathrm{~m}$ depth in the Pucci Chairlift drill hole. Most crystals have a pyramidal termination; however, a few crystals are terminated by a (100) crystal face (see arrow).
Trace-element analyses were obtained only for stilbite samples and are mostly unremarkable except for $\mathrm{Pb}$ which is high in two of the analyses (table 5). One of these stilbite specimens (79LH-0087C) also contains measurable $\mathrm{Ba}, \mathrm{Co}, \mathrm{Cr}, \mathrm{Ga}, \mathrm{Sr}$, and $\mathrm{Ti}$, as well as significant $\mathrm{Cu}, \mathrm{Mn}$, $\mathrm{V}$, and $\mathrm{Zn}$. The other specimen (79CCQ-2001H-2) contains some $\mathrm{Ba}, \mathrm{Co}, \mathrm{Cr}, \mathrm{Cu}, \mathrm{Ga}, \mathrm{Mn}, \mathrm{Ni}, \mathrm{Sr}, \mathrm{Ti}, \mathrm{V}$, and $\mathrm{Zn}$, along with the highest $\mathrm{Pb}$ value obtained in any traceelement analysis of Mount Hood zeolite minerals. Addition of $\mathrm{H}_{2} \mathrm{O}$ content (from table 5) to the stilbite electronmicroprobe analysis for sample 79CCQ-0088D-2 (table 11) results in a very reasonable chemical analysis, which is close to the stoichiometric formula for stilbite (Gottardi and Galli (1985). However, adding $\mathrm{H}_{2} \mathrm{O}$ content (table 5) to the higher silica electron-microprobe analyses for stilbite from specimen $79 \mathrm{LH}-0087 \mathrm{C}$ (table 11) results in totals that are greater than 100 percent.

\section{CLAY MINERALS}

\section{KAOLINITE AND HALLOYSITE}

Five of the Mount Hood geothermal drill holes (table 1, Nos. 1, 3, 7, 12, and 13) contain kaolinite. Orange (iron oxide stained), cream, and white (bleached) subangular to

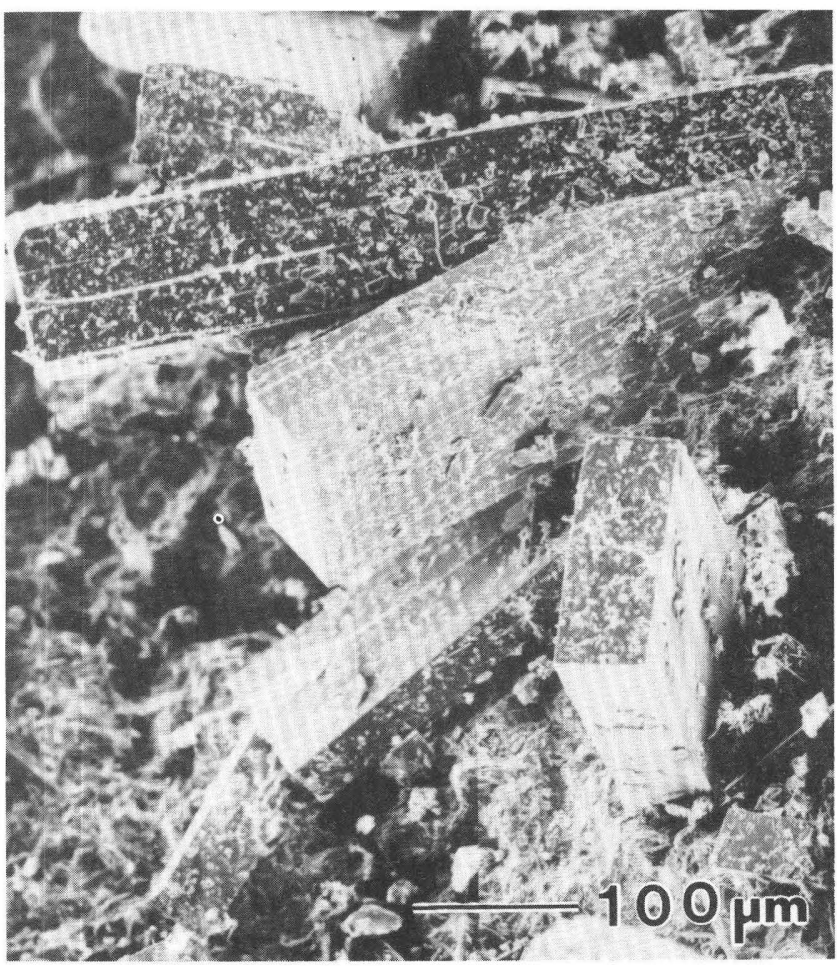

Figure 16. Scanning electron micrograph showing euhedral, columnar stellerite(?) crystals from altered volcanic rocks of the Rhododendron Formation south of Mount Hood. 
Table 11. Electron-microprobe analyses of stilbite associated with the Laurel Hill intrusion.

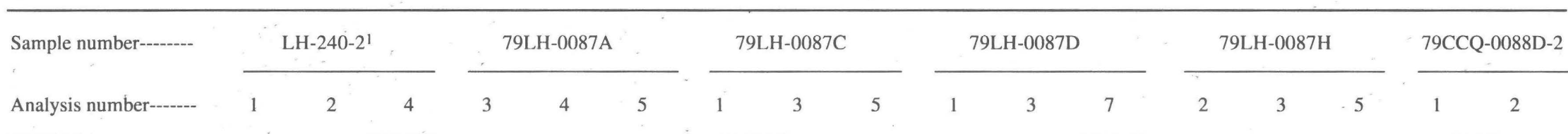

\begin{tabular}{|c|c|c|c|c|c|c|c|c|c|c|c|c|c|c|c|c|c|}
\hline \multirow{2}{*}{ 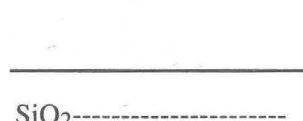 } & \multicolumn{15}{|c|}{ Major-element chemical analyses (wt percent oxides) } & \\
\hline & 62.26 & 61.41 & 62.08 & 59.81 & 60.52 & 60.15 & 60.11 & 57.46 & 59.88 & 57.82 & 58.91 & 62.77 & 61.52 & 61.83 & 59.57 & 55.91 & 56.24 \\
\hline $\mathrm{Al}_{2} \mathrm{O}_{3}$ & 17.81 & 17.13 & 17.90 & 18.26 & 17.90 & 17.10 & 17.18 & 17.27 & 17.54 & 15.20 & 17.57 & 16.84 & 18.48 & 17.81 & 17.90 & 15.97 & 15.62 \\
\hline $\mathrm{Fe}_{2} \mathrm{O}_{3}$ & 0.00 & 0.06 & 0.00 & 0.20 & 0.03 & 0.06 & 0.00 & 0.00 & 0.00 & 0.00 & 0.00 & 0.00 & 0.00 & 0.02 & 0.04 & 0.00 & 0.02 \\
\hline MgO- & 0.06 & 0.04 & 0.04 & 0.54 & 0.13 & 0.15 & 0.16 & 0.15 & 0.12 & 0.07 & 0.12 & 0.24 & 0.02 & 0.14 & 0.11 & 0.10 & 0.04 \\
\hline MnO------------------- & 0.00 & 0.00 & 0.00 & 0.00 & 0.00 & 0.00 & 0.00 & 0.04 & 0.01 & 0.01 & 0.00 & 0.00 & 0.00 & 0.02 & 0.04 & 0.00 & 0.00 \\
\hline $\mathrm{CaO}-1-$ & 8.78 & 8.52 & 8.68 & 8.81 & 8.66 & 8.45 & 8.56 & 8.14 & 8.35 & 7.87 & 8.49 & 8.62 & 8.77 & 8.45 & 8.02 & 7.69 & 7.78 \\
\hline $\mathrm{Na}_{2} \mathrm{O}-$ & 0.51 & 0.55 & 0.87 & 1.00 & 1.03 & 0.87 & 0.77 & 1.62 & 1.10 & 0.52 & 0.58 & 0.41 & 0.98 & 0.62 & 1.05 & 1.28 & 1.48 \\
\hline $\mathrm{K}_{2} \mathrm{O}$ & 0.07 & $\underline{0.08}$ & 0.06 & $\underline{0.08}$ & $\underline{0.07}$ & $\underline{0.05}$ & $\underline{0.24}$ & $\underline{0.28}$ & $\underline{0.26}$ & $\underline{0.23}$ & $\underline{0.38}$ & $\underline{0.36}$ & $\underline{0.10}$ & 0.14 & 0.12 & $\underline{0.08}$ & 0.14 \\
\hline 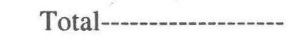 & 89.49 & 87.79 & 89.63 & 88.70 & 88.34 & 86.84 & 87.02 & 84.96 & 87.26 & 81.72 & 86.05 & 89.24 & 89.87 & 89.03 & 86.85 & 81.03 & 81.32 \\
\hline
\end{tabular}

Number of atoms on the basis of 72 oxygens

\begin{tabular}{|c|c|c|c|c|c|c|c|c|c|c|c|c|c|c|c|c|c|}
\hline 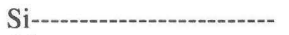 & 27.00 & 27.14 & 26.92 & 26.36 & 26.69 & 26.94 & 26.90 & 26.49 & 26.76 & 27.14 & 26.68 & 27.30 & 26.04 & 26.96 & 26.69 & 26.89 & 26.99 \\
\hline Al-------------------------- & 9.10 & 8.92 & 9.15 & 9.48 & 9.31 & 9.03 & 9.06 & 9.38 & 9.24 & 8.51 & 9.38 & 8.63 & 9.65 & 9.16 & 9.45 & 9.05 & 8.84 \\
\hline $\mathrm{Fe}-$ & 0.00 & 0.02 & 0.00 & 0.07 & 0.01 & 0.02 & 0.00 & 0.00 & 0.00 & 0.00 & 0.00 & 0.00 & 0.00 & 0.01 & 0.02 & 0.00 & 0.01 \\
\hline 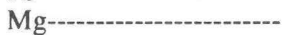 & 0.04 & 0.02 & 0.02 & 0.35 & 0.08 & 0.10 & 0.11 & 0.10 & 0.08 & 0.05 & 0.08 & 0.15 & 0.01 & 0.09 & 0.08 & 0.07 & 0.03 \\
\hline 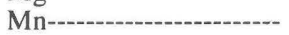 & 0.00 & 0.00 & 0.00 & 0.00 & 0.00 & 0.00 & 0.00 & 0.02 & 0.00 & 0.00 & 0.00 & 0.00 & 0.00 & 0.26 & 0.02 & 0.00 & 0.00 \\
\hline $\mathrm{Ca}-$ & 4.08 & 4.03 & 4.03 & 4.16 & 4.10 & 4.05 & 4.10 & 4.02 & 4.00 & 4.00 & 4.12 & 4.02 & 4.16 & 3.95 & 3.85 & 3.96 & 4.00 \\
\hline $\mathrm{Na}-$ & 0.43 & 0.47 & 0.73 & 0.85 & 0.88 & 0.76 & 0.67 & 1.45 & 0.96 & 0.48 & 0.51 & 0.35 & 0.84 & 0.53 & 0.91 & 1.19 & 1.38 \\
\hline K------------------------- & 0.04 & 0.04 & 0.03 & 0.02 & 0.04 & 0.03 & 0.14 & 0.17 & 0.15 & 0.14 & 0.22 & 0.20 & 0.06 & 0.08 & 0.07 & 0.05 & 0.04 \\
\hline $\mathrm{Si}+\mathrm{Al}$--_---- & 36.10 & 36.06 & 36.07 & 35.84 & 36.00 & 35.97 & 35.96 & 35.87 & 36.00 & 35.95 & 36.06 & 35.93 & 35.69 & 36.12 & 36.14 & 35.94 & 35.85 \\
\hline $\mathrm{Si} / \mathrm{Al}+\mathrm{Fe}^{3+}$ & 2.97 & 3.03 & 2.94 & 2.76 & 2.87 & 2.98 & 2.97 & 2.82 & 2.90 & 3.23 & 2.85 & 3.16 & 2.70 & 2.94 & 2.82 & 2.97 & 3.05 \\
\hline $\mathrm{Si} / \mathrm{Si}+\mathrm{Al}+\mathrm{Fe}^{3+}$ & 0.75 & 0.75 & 0.75 & 0.73 & 0.74 & 0.75 & 0.75 & 0.74 & 0.74 & 0.76 & 0.74 & 0.76 & 0.73 & 0.75 & 0.74 & 0.75 & 0.75 \\
\hline Balance error²------- & 4.57 & 3.66 & 3.12 & -3.46 & 0.54 & -0.62 & -1.76 & -5.24 & -0.24 & -2.43 & 2.69 & -2.86 & 4.36 & -0.49 & 6.75 & -2.65 & -6.68 \\
\hline
\end{tabular}

'Sample from $73.2 \mathrm{~m}$ depth in the Laurel Hill drill hole (table 1, No. 9).

${ }^{2}$ Determined by method of Passaglia (1970). 
Table 12. Electron-microprobe analyses of stellerite(?) from the Zigzag River drill hole (table 1, No. 8).

\begin{tabular}{|c|c|c|c|c|c|c|c|c|c|}
\hline \multirow{2}{*}{$\begin{array}{l}\text { Sample number }{ }^{1} .-.---- \\
\text { Analysis number--.....- }\end{array}$} & \multicolumn{3}{|c|}{ KCR-440-2 } & \multicolumn{3}{|c|}{ KCR-460-4 } & \multicolumn{3}{|c|}{ KCR-760-1 } \\
\hline & 2 & 4 & 5 & 1 & 2 & 3 & 1 & 2 & 3 \\
\hline \multicolumn{10}{|c|}{ Major-element chemical analyses (wt percent oxides) } \\
\hline 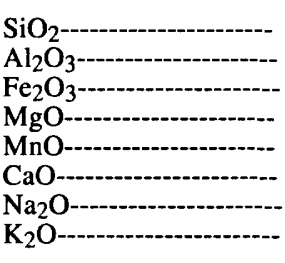 & $\begin{array}{r}62.16 \\
16.70 \\
0.00 \\
0.06 \\
0.00 \\
8.43 \\
0.40 \\
0.12 \\
\end{array}$ & $\begin{array}{r}62.74 \\
15.93 \\
0.00 \\
0.05 \\
0.00 \\
8.55 \\
0.17 \\
0.15 \\
\end{array}$ & $\begin{array}{r}61.61 \\
16.71 \\
0.00 \\
0.04 \\
0.00 \\
8.38 \\
0.41 \\
0.14 \\
\end{array}$ & $\begin{array}{r}57.25 \\
15.74 \\
0.00 \\
0.18 \\
0.00 \\
7.69 \\
0.40 \\
0.08 \\
\end{array}$ & $\begin{array}{r}57.51 \\
15.48 \\
0.00 \\
0.05 \\
0.00 \\
7.87 \\
0.21 \\
0.06 \\
\end{array}$ & $\begin{array}{r}58.09 \\
15.94 \\
0.00 \\
0.11 \\
0.00 \\
7.87 \\
0.60 \\
0.08 \\
\end{array}$ & $\begin{array}{r}61.90 \\
16.34 \\
0.03 \\
0.03 \\
0.00 \\
8.53 \\
0.15 \\
0.16 \\
\end{array}$ & $\begin{array}{r}61.45 \\
15.68 \\
0.00 \\
0.05 \\
0.00 \\
8.12 \\
0.19 \\
0.08 \\
\end{array}$ & $\begin{array}{r}62.20 \\
16.17 \\
0.00 \\
0.02 \\
0.00 \\
8.36 \\
0.13 \\
0.08 \\
\end{array}$ \\
\hline 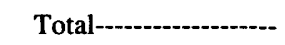 & 87.87 & 87.59 & 87.29 & 81.34 & 81.18 & 82.69 & 87.14 & 85.57 & 86.96 \\
\hline
\end{tabular}

Number of atoms on the basis of 72 oxygens

\begin{tabular}{|c|c|c|c|c|c|c|c|c|c|}
\hline 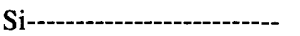 & 27.39 & 27.69 & 27.33 & 27.25 & 27.40 & 27.23 & 27.49 & 27.72 & 27.62 \\
\hline Al---- & 8.67 & 8.29 & 8.74 & 8.83 & 8.69 & 8.81 & 8.55 & 8.34 & 8.46 \\
\hline Fe--י-י-- & 0.00 & 0.00 & 0.00 & 0.00 & 0.00 & 0.00 & 0.01 & 0.00 & 0.00 \\
\hline Mg- & 0.04 & 0.03 & 0.03 & 0.13 & 0.04 & 0.08 & 0.02 & 0.03 & 0.02 \\
\hline 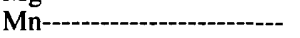 & 0.00 & 0.00 & 0.00 & 0.00 & 0.00 & 0.00 & 0.00 & 0.00 & 0.00 \\
\hline Ca-- & 3.98 & 4.04 & 3.99 & 3.92 & 4.02 & 3.96 & 4.06 & 3.92 & 3.98 \\
\hline 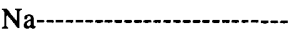 & 0.34 & 0.14 & 0.35 & 0.37 & 0.20 & 0.54 & 0.13 & 0.26 & 0.11 \\
\hline K--1-2-1 & 0.07 & 0.08 & 0.08 & 0.05 & 0.04 & 0.05 & 0.09 & 0.04 & 0.04 \\
\hline $\mathrm{Si}+\mathrm{Al}-$ & 36.06 & 35.98 & 36.07 & 36.08 & 36.09 & 36.04 & 36.04 & 36.05 & 36.08 \\
\hline $\mathrm{Si} / \mathrm{Al}+\mathrm{Fe}^{3+}$ & 3.16 & 3.34 & 3.13 & 3.09 & 3.15 & 3.09 & 3.21 & 3.32 & 3.27 \\
\hline $\mathrm{Si} / \mathrm{Si}+\mathrm{Al}+\mathrm{Fe}^{3+}$ & 0.76 & 0.77 & 0.76 & 0.76 & 0.76 & 0.76 & 0.76 & 0.77 & 0.77 \\
\hline Balance error ${ }^{2}-$ & 2.80 & -1.06 & 3.34 & 3.78 & 4.23 & 1.80 & 2.20 & 2.67 & 3.93 \\
\hline
\end{tabular}

'Samples are from depths of $134.1,140.2$, and $231.6 \mathrm{~m}$, respectively.

${ }^{2}$ Determined by method of Passaglia (1970).

well-rounded grains within drill cuttings from volcaniclastic debris intervals in these drill holes have kaolinite in association with one or more other alteration minerals: opal, chalcedony, jarosite, natrojarosite, alunite, natroalunite, pyrite, smectite, hematite, or calcite. Erratic cobbles and boulders in glacial moraine at an elevation of $1,878 \mathrm{~m}$ on the northwestern side of Mount Hood contain kaolinite, specular hematite, opal, alunite, gypsum, anhydrite, and sulfur. Such occurrences of kaolinite and associated minerals appear to be due to acid-sulfate alteration near the summit of Mount Hood and were transported downslope by various mechanisms including glacial, lahar, and fluvial processes. Similar silica minerals, iron oxides, iron hydroxides, sulfate minerals, and sulfur are presently being formed by acidic fumarolic alteration in vent areas near the top of Mount Hood (Beeson and others, 1980).

Local acid conditions appear to have existed previously in other parts of the volcano. White kaolinite coats quartz crystals that line open spaces in orange stained, altered, volcanic breccia from an outcrop on the north bank of Iron
Creek (southeast of Mount Hood). Also, broad $7 \AA$ X-ray peaks, suggesting halloysite, occur in analyses of (1) an orange clay sample coating a joint surface in a quarry south of Mount Hood and (2) drill cuttings containing hematite and chalcedony from $49 \mathrm{~m}$ depth in drill hole 11 (table 1 ).

One green clay sample, associated with quartz and mixed-layer illite-smectite, from the Cheeney Creek mining area has no (001) or (003) X-ray diffraction reflections and has strong (002) and (004) reflections at 7.12 and 3.56 $\AA$, respectively. Probably, this mineral belongs to the serpentine-kaolinite mineral group.

\section{CELADONITE}

Drill cuttings of the Columbia River Basalt Group from the Clear Fork drill hole (table 1, No. 6) contain bluegreen celadonite-bearing grains between depths of 363 and $369 \mathrm{~m}$ in association with chalcedony, smectite, and chlorite. Blue-green celadonite also was identified along with 
smectite, mordenite, and heulandite at one outcrop of altered Rhododendron Formation rocks from northwest of Mount Hood. Celadonite and associated secondary minerals similar to those listed above commonly occur in basalt vesicles and altered volcaniclastic rocks owing to diagenetic alteration or low-temperature zeolitic alteration (Wise and Eugster, 1964).

\section{SMECTITE}

Smectite is the most widespread secondary mineral in the vicinity of Mount Hood. All but one drill hole (table 1, No. 11) and most sampled outcrops contain at least minor amounts of smectite as groundmass alteration, fracture linings, or vug coatings. The exchangeable cation in the Mount Hood smectites is $\mathrm{Ca}$ because $\mathrm{X}$-ray diffraction analyses of more than 300 smectite samples show basal (001) reflections between about 14 and $16 \AA$ (average near $15 \AA$ ) (Grim, 1968) that expand to between 16.5 and $18 \AA$ after being heated at $60^{\circ} \mathrm{C}$ for 1 hour in an atmosphere of ethylene glycol. Basal spacings of a few samples heated to $400^{\circ} \mathrm{C}$ for 0.5 hour collapsed to $10 \AA$. Many of the clays are poorly crystalline and have low, broad, asymmetrical basal peaks, but some smectite occurrences, generally associated with late Tertiary rocks, have high, sharp peaks characteristic of well-crystallized smectite. Origin of the smectite probably is variable, ranging from weathering to fumarolic alteration, hydrothermal alteration, or diagenetic processes.

\section{ILLITE}

White-, gray-, black-, or orange-stained illite occurs in several Mount Hood drill holes [table 1, Nos. 4(?), 5, 7, $8(?), 10,12$ and 13(?)] and numerous outcrops surrounding the mountain. X-ray diffraction analyses show a low, broad to fairly sharp, basal (001) peak ranging from about 9.5 to $10.4 \AA$ (average of 31 measurements is $10.0 \AA$ ). The basal peak contracts slightly to about $9.8 \AA$ after heating for 1 hour at $60^{\circ} \mathrm{C}$ in an atmosphere of ethylene glycol. Secondary minerals associated with illite near Mount Hood include calcite, pyrite, quartz, chlorite, smectite, hematite, epidote, and chalcedony. In outcrop samples, illite fills vesicles, coats fractures, or is deposited in open spaces between breccia fragments of late Tertiary volcanic rocks (Columbia River Basalt Group, Rhododendron Formation, and late Tertiary andesite lava flows). Drill-cuttings samples from two drill holes (table 1, Nos. 8 and 10) contain a small amount of illite in association with microquartz diorite of the Still Creek and Laurel Hill intrusions. Illite in the remaining drill holes is found in Quaternary clastic debris units that consist of pyroclastic, avalanche, mudflow, or fluvial deposits (Wise, 1969). Illite and other minerals that cannot have formed at near-surface conditions on the lower slopes of Mount Hood probably originated, because of high-temperature hydrothermal alteration or fumarolic processes within or close to the vent, near the summit of the mountain and were transported downslope to the drill site. Frank (1983) reported that high-temperature hydrothermal minerals such as illite have been transported considerable distances from their source near the top of Mount Baker, Washington.

\section{MIXED-LAYER ILLITE-SMECTITE}

Drill-cuttings samples from drill holes 4,7 , and 13 (table 1) and a few rock outcrop samples from the north side of Zigzag Mountain and the Cheeney Creek mining area southwest of Mount Hood contain mixed-layer illite-smectite. Some of the white, light green, or black, mixed-layer clay samples have a fairly sharp $\sim 10$ to $12 \AA \mathrm{X}$-ray diffraction peak that splits into two peaks at $\sim 11$ to $14 \AA$ and $\sim 9$ to $10 \AA$ after exposure to ethylene glycol at $60^{\circ} \mathrm{C}$ for 1 hour. A few other samples have a broad basal X-ray peak near $\sim 10$ to $11 \AA$ that becomes more asymmetrical and much broader following glycolation; however, the only measurable peak is near $\sim 9.7 \AA$. These mixed-layer clays are allevardite ordered with the illite content ranging from about 70 to 90 percent (Hower, 1981; Horton, 1985). One X-rayed sample from drill hole 4 (table 1) has a $12.8 \AA$ $d(001)$ peak that splits into $\sim 17$ and $9.5 \AA$ peaks following glycolation. Another sample from the same drill hole has a $15.3 \AA$ basal peak that splits into $\sim 16.9$ and $\sim 9.5 \AA$ peaks after glycolation. Both clay samples have random interstratification with about 50 to 60 percent illite (Hower, 1981).

The majority of mixed-layer illite-smectite samples from the Mount Hood area were obtained from fractures and altered andesite lavas and tuffs in the late Tertiary Rhododendron Formation. Associated secondary minerals include limonite, hematite, quartz, chalcedony, smectite, chlorite, calcite, pyrite, and galena. Mixed-layer illitesmectite also occurs in two Quaternary clastic debris samples from the Pucci Chairlift drill hole (table 1, No. 13). Mixed-layer clay in these clastic deposits must have originated at a higher elevation on Mount Hood and was later transported downslope. Frank (1983) identified mixedlayer illite-smectite and numerous other secondary minerals from clay-size fumarolic ejecta and recent tephras erupted from Sherman Crater near the summit of Mount Baker, Washington, in 1975.

\section{CHLORITE}

Chlorite was identified in several drill holes (table 1 , Nos. $4,5,6,7,8,9,10$, and 13) and numerous outcrops surround- 
ing Mount Hood. Most chlorite deposits are restricted to late Tertiary rocks of the Rhododendron Formation, Laurel Hill and Still Creek intrusions, lower andesite flows (unit Tla in fig. 3), and vein fillings associated with these rock units. Only two samples of reworked Quaternary detrital deposits (from drill holes 7 and 13 in table 1) contain chlorite-bearing vein deposits. A few thin sections show that chlorite formed from alteration of mafic minerals; however, most occurrences of chlorite near Mount Hood are found in vein fillings and were deposited from circulating fluids. The chlorite deposits are associated with minerals such as epidote and chabazite, which are stable at quite different temperature conditions $\left(230^{\circ} \mathrm{C}\right.$ and $<100^{\circ} \mathrm{C}$, respectively) (Seki, 1972; Kristmannsdóttir and Tómasson, 1978). Most chlorite at Mount Hood probably formed at temperatures above $200^{\circ} \mathrm{C}$ during cooling of the many intrusive rocks in the area. It should be noted, however, that chlorite has been found at temperatures near $100^{\circ} \mathrm{C}$ (Hulen and Nielson, 1986) and the possibility of lower temperature chlorite cannot be discounted.

$\mathrm{X}$-ray diffraction analyses show that the (002) and (004) $\mathrm{X}$-ray reflections of Mount Hood chlorite are much stronger than its (001) and (003) reflections, which suggests that the mineral is Fe-rich (Grim, 1968). Holdaway and Bussey (1982) presented electron-microprobe analyses of chlorite from the Old Maid Flat 7A drill hole. They suggest that minor $\mathrm{Ca}$ and other chemical characteristics of the mineral indicate the presence of randomly interlayered saponite-chlorite. No chemical analyses of chlorite were attempted for this report, but one sample, examined by SEM with EDS, contains some $\mathrm{Ca}, \mathrm{K}$, and $\mathrm{Mg}$ in addition to $\mathrm{Fe}, \mathrm{Al}$, and $\mathrm{Si}$.

\section{MIXED-LAYER CHLORITE-SMECTITE}

Occasional rock samples containing randomly interstratified mixed-layer chlorite-smectite were found in association with Tertiary quartz diorite outcrops on the south and east sides of Mount Hood. One sample of cuttings from drill hole 13 (table 1) also contains mixed-layer clay minerals in a Tertiary(?) andesite lava flow. The majority of randomly interstratified mixed-layer chlorite-smectite samples noted in this study were found in the Rhododendron Formation, as well as some drill-cuttings samples of the Columbia River Basalt Group from drill holes 4, 5, 6, and 7 (table 1) on the northwest flank of the mountain. Randomly interstratified mixed-layer chlorite-smectite in the Mount Hood samples is characterized by a weak (002) Xray reflection and a strong (001) reflection at $\sim 14.2 \AA$ that expands to $\sim 15 \AA$ (expansion range for Mount Hood samples is 14.4 to $15.8 \AA$ ) following exposure to ethylene glycol fumes for 1 hour at $60^{\circ} \mathrm{C}$. The large range of expanded (001) values probably is due to variation in the ratio of chlorite to smectite in individual samples (Hower, 1981, table 3.6). Holdaway and Bussey (1982) identified randomly interstratified mixed-layer chlorite-smectite throughout much of the nearby OMF-7A drill hole and suggested that it is converted to chlorite with increasing temperature and pressure. They found a small $31-\AA$ peak in three samples, indicating a more ordered interstratification of the mixed-layer clay.

The (001) reflection at $\sim 14 \AA$ did not expand with glycolation of a few Mount Hood samples. These mixed-layer clays may consist of chlorite-vermiculite, although no 28$\AA$ peak was observed. According to Reynolds (1980) this higher order X-ray reflection is only visible when chlorite and vermiculite are present in nearly equal amounts.

\section{SEPIOLITE(?)}

The Last Chance Mountain (table 1, No. 4) drill cuttings contain caramel-colored clay grains between depths of 30.5 and $137.2 \mathrm{~m}$ that may consist of sepiolite. X-ray diffraction analyses show a very sharp peak at $12.1 \AA$ that changed very little with glycolation (max expansion $~ 12.4$ $\AA$ ); the peak contracts to $11.8 \AA$ and is somewhat reduced in intensity when the sample is heated to $400^{\circ} \mathrm{C}$ for 0.5 hour. After heating to $550^{\circ} \mathrm{C}$ for 0.5 hour, there is additional contraction to $11.3 \AA$ and considerable reduction in intensity although the peak is not completely destroyed. Such behavior with heating and glycolation appears to be similar to that of sepiolite (Starkey and others, 1984).

The caramel-colored clay particles were not observed adhering to the volcanic fragments that compose the drill cuttings and thus may have been introduced during drilling; however, no samples of drill mud used in completing this drill hole were obtained for comparative analysis. Sepiolite usually occurs as an alteration product of magnesium carbonates or silicates (Phillips and Griffen, 1981); however, these minerals do not occur in the Last Chance Mountain drill hole. Other secondary minerals identified in the same samples as the caramel-colored clay grains include $B$-cristobalite, chalcedony, quartz, epidote, stilbite, calcite, smectite, chlorite, mixed-layer illite-smectite, pyrite, hematite, and amorphous iron oxide.

\section{SULFATE MINERALS}

\section{GYPSUM-ANHYDRITE}

Five Mount Hood drill holes (table 1, Nos. 1, 2, 4, 11, and 13) contain small amounts of soft, colorless or yellow, needlelike crystals of gypsum. One gypsum-bearing Quaternary andesite sample from drill hole 11 is associated with common constituents (calcite, brownmillerite and thaumasite) of cement (Taylor, 1964), suggesting that the gypsum was introduced in the drill hole during drilling. 
Most gypsum occurs in Quaternary debris units and one Tertiary andesite flow where the mineral was deposited on (or associated with) pyrite crystals. This gypsum probably formed by oxidation of the pyrite and could have been deposited after recovery of the drill-hole samples because gypsum precipitates at fairly low temperatures $\left(<70^{\circ} \mathrm{C}\right)$ (Holland and Malinin, 1979). Other minerals associated with the gypsum include alunite, natroalunite, jarosite, and natrojarosite; these sulfate minerals probably formed by acid-sulfate fumarolic alteration and were later transported by various mechanisms and deposited as Quaternary debris units.

$\mathrm{X}$-ray diffraction analyses of fumarolic alteration material collected in moraine deposits on the west side of Mount Hood show the presence of sulfur, kaolinite, opal, alunite, gypsum, hematite, and anhydrite. Sulfur is a common fumarolic mineral precipitate. Kaolinite, opal, alunite, anhydrite, and gypsum probably formed during surficial oxidation of sulfur; they have been collected from the active fumarole area of Mount Baker, Washington (Babcock and Wilcox, 19.77; Frank, 1983). Keith and others (1981) listed sulfur, gypsum, alunite, anhydrite, and hematite among the fumarole minerals deposited at temperatures below $250^{\circ} \mathrm{C}$ at Mount St. Helens Washington.

\section{ALUNITE-NATROALUNITE AND JAROSITE-NATROJAROSITE}

One or more of the sulfate minerals alunite (K-rich), natroalunite (Na-rich), jarosite $(\mathrm{K}+\mathrm{Fe})$, or natrojarosite $(\mathrm{Na}+\mathrm{Fe})$ were identified from Quaternary debris deposits in Mount Hood drill holes 1, 2, 3, 7, 12, and 13 (table 1) and from surface samples of reworked debris on the west side of the mountain. All of these minerals probably form under similar conditions. In fact, extensive solid solution exists between alunite and natroalunite, and jarosite and natrojarosite; isomorphous substitution can also occur between alunite and jarosite (Brophy and others, 1962). Drill-cuttings samples containing these sulfate minerals usually have a bleached appearance or are orange stained. Associated secondary minerals include kaolinite, smectite, opal, gypsum, pyrite, hematite, and sulfur. Probably all of the minerals formed from fumarolic alteration near the summit of Mount Hood and were carried downslope by mudflows, debris flows, avalanche, glacial reworking, and other mechanisms.

\section{ANGLESITE}

A sample of fault breccia from the Rhododendron Formation in the Cheeney Creek Mining Area southwest of Mount Hood contains anglesite along with cerussite, galena, sphalerite, pyrite, quartz, calcite, amorphous iron oxide (limonite?), and mixed-layer illite-smectite. The nearly opaque, gray anglesite probably formed by oxidation of galena.

\section{SULFIDE MINERALS}

\section{GALENA AND SPHALERITE}

A sample containing galena and sphalerite was collected on the north side of Zigzag Mountain from an epithermal vein deposit in volcanic rocks of the Rhododendron Formation (Keith and Causey, 1982, 1984). Associated secondary minerals include quartz, calcite, chlorite(?), illite, chalcopyrite, dolomite, and cerussite. Mineralization occurs within a 0.3 -m-wide quartz vein along a steeply dipping north-northwest fracture zone. Semiquantitative chemical analysis of the mineralized vein sample showed (in ppm) $\mathrm{Ag}=15, \mathrm{Cd}=200, \mathrm{Cu}=5,000, \mathrm{~Pb}=7,000$, and $\mathrm{Zn}>10,000$ (Keith and others, 1980; Keith, Bargar, and Beeson, 1982). Keith and Causey (1982) indicated that claims had been staked along this vein but no production was reported and that the area has little potential for economic deposits.

\section{CHALCOPYRITE}

Chalcopyrite was identified in drill holes 8 and 9 (table 1) and at one surface location other than the sample discussed above with galena and sphalerite. The two drill holes penetrated quartz diorite of the Laurel Hill intrusion, and a grain of chalcopyrite was identified in one sample from each drill hole; other secondary minerals identified in these two samples include quartz, chlorite, epidote, magnetite, calcite and laumontite. Two very altered andesite samples of the Rhododendron Formation, containing vein fillings of tarnished chalcopyrite, magnetite, chlorite, quartz, epidote, oxidized bladed hematite, stilbite, and calcite, were collected at a rock quarry near the Laurel Hill intrusion south of Mount Hood. Secondary minerals in both drill cuttings and surface samples indicate that the rocks are predominantly affected by propylitic alteration due to pluton emplacement.

\section{PYRITE}

Pyrite, occurring in drill holes 1 through 8 and 13 (table 1 ), as well as in several surface samples, is a common secondary mineral in the Mount Hood area. Some pyrite was deposited as thin crusts on bleached Quaternary debris grains in association with minerals such as gypsum, hematite, natroalunite and opal; these minerals probably formed in areas of fumarolic alteration (Babcock and Wil- 
Table 13. Electron-microprobe analyses of pyrite from fractures in Tertiary volcanic rocks near Mount Hood.

[Analyses in wt percent of elements]

\begin{tabular}{|c|c|c|c|c|c|c|}
\hline \multirow{2}{*}{$\begin{array}{l}\text { Sample number } \\
\text { Analysis number }\end{array}$} & \multicolumn{3}{|c|}{ 79BM-2046A } & \multicolumn{3}{|c|}{ 79BM-2046G } \\
\hline & 1 & 2 & 3 & 1 & 2 & 3 \\
\hline 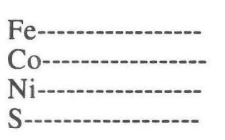 & $\begin{array}{r}46.12 \\
0.03 \\
0.00 \\
52.44 \\
\end{array}$ & $\begin{array}{r}45.67 \\
0.02 \\
0.00 \\
51.71 \\
\end{array}$ & $\begin{array}{r}45.83 \\
0.01 \\
0.00 \\
52.90 \\
\end{array}$ & $\begin{array}{r}45.89 \\
0.04 \\
0.00 \\
52.97 \\
\end{array}$ & $\begin{array}{r}45.98 \\
0.03 \\
0.00 \\
52.54 \\
\end{array}$ & $\begin{array}{r}45.85 \\
0.02 \\
0.00 \\
52.60 \\
\end{array}$ \\
\hline Total----------- & 98.59 & 97.40 & 98.74 & 98.90 & 98.55 & 98.47 \\
\hline 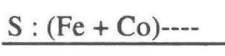 & 1.98 & 1.97 & 2.01 & 2.01 & 1.99 & 2.00 \\
\hline Sample number & $79 \mathrm{~B}$ & M-2046 & & 79IC & -2033 & \\
\hline Analysis number & 3 & 5 & 8 & 1 & 2 & \\
\hline 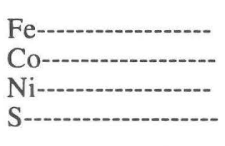 & $\begin{array}{r}46.09 \\
0.02 \\
0.00 \\
53.34 \\
\end{array}$ & $\begin{array}{r}46.59 \\
0.01 \\
0.00 \\
53.37 \\
\end{array}$ & $\begin{array}{r}45.74 \\
0.06 \\
0.00 \\
52.87 \\
\end{array}$ & $\begin{array}{r}45.46 \\
0.07 \\
0.00 \\
52.15 \\
\end{array}$ & $\begin{array}{r}45.49 \\
0.05 \\
0.00 \\
52.38 \\
\end{array}$ & \\
\hline Total----------- & 99.45 & 99.97 & 98.67 & 97.68 & 97.92 & \\
\hline $\mathrm{S}:(\mathrm{Fe}+\mathrm{Co})----$ & 2.01 & 1.99 & 2.01 & 2.00 & 2.00 & \\
\hline
\end{tabular}

cox, 1977) and were later transported downslope. Other pyrite-bearing grains from the Rhododendron Formation and Tertiary andesite flows appear to have formed as epithermal vein fillings along with later smectite and calcite or quartz. Most pyrite crystals are cubic, but a few pyritohedrons were observed. The crystal size is usually small and was measured at $0.01 \mathrm{~mm}$ in one disseminated pyrite drill-cuttings sample. Although widespread in occurrence, few samples contain very abundant pyrite. Highly mineralized fault gouge in drill cuttings from the bottom of drill hole 5 (table 1), from outcrops in the Cheeney Creek area (southwest of Mount Hood), and along Iron Creek (southeast of Mount Hood) contain significant pyrite. Chemical analyses of pyrite from the last two areas (table 13) show minor $\mathrm{Co}$ in addition to $\mathrm{Fe}$ and $\mathrm{S}$, but no Ni was detected.

\section{IRON OXIDE-HYDROXIDE MINERALS}

\section{AMORPHOUS IRON OXIDE-HYDROXIDE}

Orange- and red-stained drill cuttings from drill holes 1 and 4 (table 1) are amorphous to X-rays. The amorphous iron-oxide- or iron-hydroxide-stained grains occur as hydrothermal fracture coatings on Tertiary andesite in drill hole 4. In drill hole 1, orange-stained Quaternary debris grains probably were transported from fumarolic areas higher on Mount Hood; associated minerals include opal, kaolinite, smectite, pyrite, and sulfates (alunite, natroalunite, jarosite, and natrojarosite). One sample from a mineralized fracture zone in the Cheeney Creek area also has considerable orange, earthy, amorphous-iron staining along with cerussite, sphalerite, and quartz. Because the orangered, iron-bearing deposits are amorphous, it is uncertain whether the minerals consist of iron oxide or iron hydroxide or both.

\section{GOETHITE}

One sample from the Iron Creek area has a vein deposit of tiny, euhedral quartz crystals that are coated by later, orange, earthy goethite (identified by X-ray). Other secondary minerals in the sample are pyrite and epidote; the goethite possibly formed by oxidation of pyrite.

\section{HEMATITE}

$\mathrm{X}$-ray diffraction analyses show that iron oxide stains found in many Mount Hood drill holes (table 1, Nos. 2 through 7, 11, and 12) and surface samples consist of hematite. The occurrence of hematite in all rock units sampled, ranging from lava flows of the Columbia River Basalt Group to the youngest Holocene fumarolic deposits, shows that the origin of the hematite is quite varied. Many andesitic flows have reddish hematite alteration that appears to be deuteric and formed during cooling of the surface of lava flows by oxidation of mafic minerals. Some thin sections of these flows also show reddish oxidation rims that probably are hematite surrounding mafic minerals. Bladed hematite crystals were noted in pore spaces of some andesitic rocks along with vapor-phase tridymite. Many of the Quaternary debris units contain bleached and orange hematite-stained grains in association with secondary minerals, such as opal, kaolinite, and sulfate minerals, that suggest a fumarolic origin. Finally, hematite possibly formed from oxidation of pyrite was identified in mineralized veins from several areas near Mount Hood.

\section{MAGNETITE}

Thin magnetite veins, in association with epidote, chlorite, and quartz, occur in quartz diorite of the Laurel Hill and Still Creek intrusions, both in drill cuttings from drill holes 8, 9, and 10 (table 1) and in outcrop samples. This propylitic mineralization undoubtedly occurred as a very late stage during cooling of the intrusions. 


\section{OTHER MINERALS}

\section{EPIDOTE}

Secondary epidote occurs in quartz diorite drill cuttings from the Laurel Hill and Still Creek intrusions penetrated by drill holes 8,9 , and 10 (table 1). A few samples of Quaternary debris from drill holes 7 and 10 (table 1) also contain traces of epidote. Moreover, epidote was identified in drill hole 4 (table 1) in association with possible quartz diorite dike material; vertical dikes, less than $100 \mathrm{~m}$ from this drill hole, are shown on a geologic map by Priest and others (1982). Several surface samples of quartz diorite from the Laurel Hill intrusion contain epidote. Epidote was also found in propylitically altered rocks of the Rhododendron Formation collected close to this intrusion. Similar epidote-bearing propylitic alteration can be found in the late Tertiary andesites near Iron Creek and the Barlow Pass-Bennet Pass area southeast of Mount Hood.

Bright-green, euhedral, acicular, epidote crystals (fig. 17) fill veins and vesicles in the late Tertiary intrusive and extrusive igneous rocks near Mount Hood; some also occurs in open spaces between breccia fragments and is disseminated in bleached rock adjacent to fractures. Most epidote from the drill holes and surface samples is associated with earlier(?) chlorite, and coeval(?) magnetite and quartz. Zeolites, clay minerals, and other secondary minerals in these samples are later deposits.

Composition of Mount Hood epidote ranges from about 15 to 33 percent pistacite (Ps) (table 14) and averages about 23 percent Ps. Minor epidote reported from the Old Maid Flat 7A drill hole (Holdaway and Bussey, 1982) is 25 percent Ps. In this study, considerable differences in Ps values were observed both between individual crystals and within a single crystal. The analyses in table 14 show significant $\mathrm{Fe}^{3+} / \mathrm{Al}$ substitution in all analyzed samples. Occasional grains have patches that contain abundant $\mathrm{Mn}$ or $\mathrm{Mg}$, but no systematic occurrences of these elements were observed.

\section{TITANITE(?)}

During electron-microprobe analyses of epidote, one of the samples (LH240-2) from drill hole 9 (table 1) yielded a single analysis that contains significant titanium ( 34.07 $\mathrm{SiO}_{2}, 11.29 \mathrm{Al}_{2} \mathrm{O}_{3}, 21.13 \mathrm{TiO}_{2}, 5.79 \mathrm{Fe}_{2} \mathrm{O}_{3}, 0.04 \mathrm{MgO}$, $0.0 \mathrm{MnO}$, and $25.70 \mathrm{CaO}$; total weight percent oxides = 98.02). Subsequent examination of the polished thin section in transmitted light showed that there are clayey(?) concentrations of a brown to nearly opaque mineral between many epidote crystals; in reflected light, the mineral appears to be yellowish to grayish in color and might be leucoxene. Leucoxene is a general term for an alteration product of ilmenite, and it may consist of one or more titanium-bearing minerals (Phillips and Griffen, 1981).
The only titanium-bearing mineral that might be even remotely suggested by our chemical analysis is titanite (sphene). A surface vein sample from the same location as drill hole 9 contains tourmaline, apatite, and another mineral observed only in SEM. EDS semiquantitative chemical analysis of this unidentified mineral showed significant $\mathrm{Ca}, \mathrm{Ti}$, and $\mathrm{Si}$ and smaller concentrations of $\mathrm{Al}, \mathrm{Fe}$, and $\mathrm{Mn}$. On the basis of the $\mathrm{Si}, \mathrm{Ti}$, and $\mathrm{Ca}$ determinations, these two mineral occurrences are tentatively identified as titanite(?).

Authigenic titanite has been reported in association with laumontite in New Zealand zeolite-facies metamorphosed rocks (Boles and Coombs, 1977). Hydrothermally altered sandstones of the Cerro Prieto geothermal field, Mexico, also contain titanite, which Schiffman and others (1985) indicated probably formed at temperatures that did not exceed $150{ }^{\circ} \mathrm{C}$. Boles and Coombs (1977) indicated that their analyses confirmed that substitution of $\mathrm{Al}$ and $\mathrm{Fe}^{3+}$ for $\mathrm{Ti}$ is one of the characteristics of sphene in very low grade metamorphic rocks. Schiffman and others (1985) described

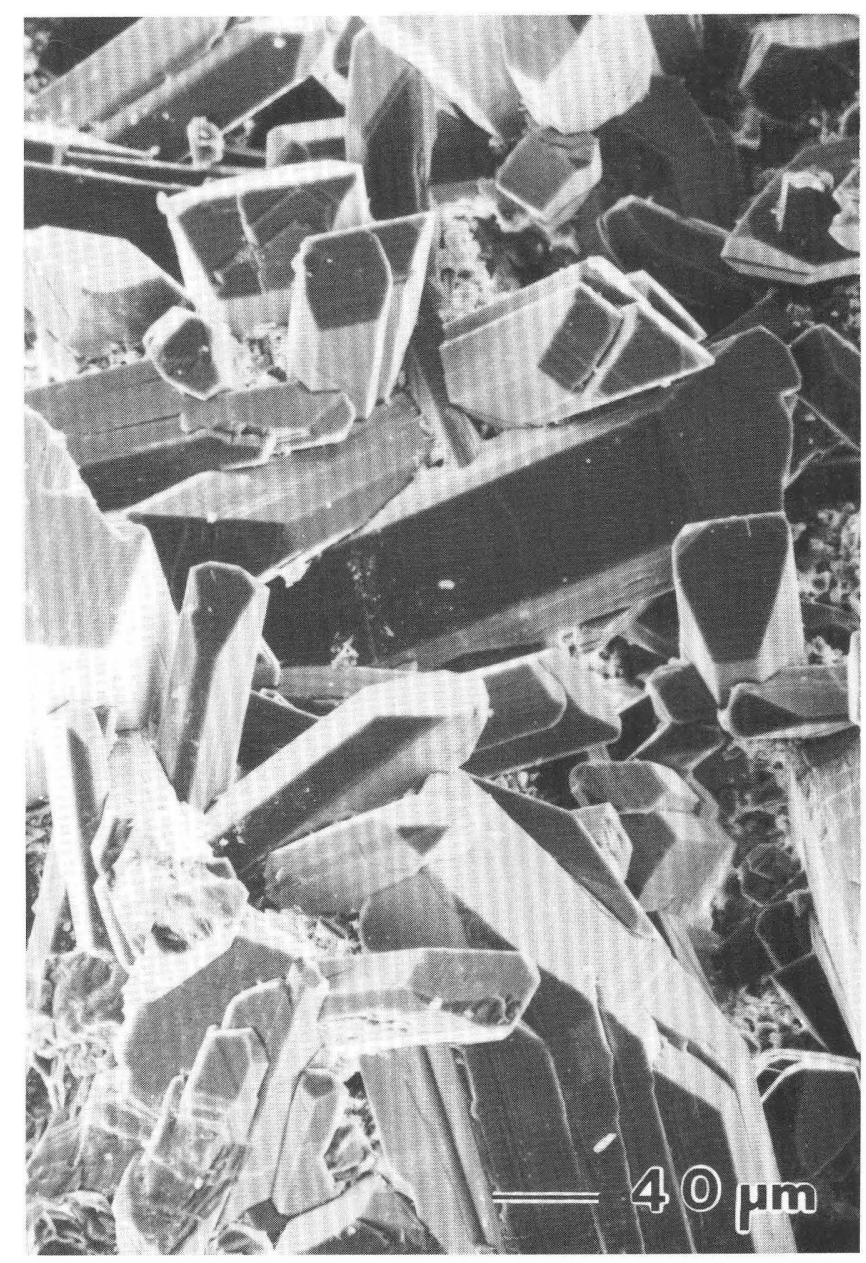

Figure 17. Scanning electron micrograph showing euhedral columnar crystals of epidote from $\sim 116 \mathrm{~m}$ depth in the Zigzag River drill hole (table 1, No. 8). 
Table 14. Electron-microprobe analyses of epidote from drill holes and outcrops near Mount Hood.

\begin{tabular}{|c|c|c|c|c|c|c|c|c|c|c|c|c|c|c|c|c|c|c|}
\hline \multirow{2}{*}{$\begin{array}{l}\text { Sample number------- } \\
\text { Analysis number------- }\end{array}$} & \multicolumn{3}{|c|}{ 79LH-0087A } & \multicolumn{3}{|c|}{ 79CCQ-2001B } & \multicolumn{3}{|c|}{$79 \mathrm{CCQ}-2001 \mathrm{~F}$} & \multicolumn{3}{|c|}{ LH-40-2 } & \multicolumn{3}{|c|}{ LH-240-2 } & \multicolumn{3}{|c|}{ 79IC-2032 } \\
\hline & 1 & 2 & 3 & 1 & 3 & 5 & 1 & 2 & 4 & 1 & 3 & 5 & 1 & 2 & 5 & 1 & 2 & 5 \\
\hline
\end{tabular}

Major-element chemical analyses (wt percent oxides)

\begin{tabular}{|c|c|c|c|c|c|c|c|c|c|c|c|c|c|c|c|c|c|c|}
\hline $\mathrm{SiO}_{2}$ & 37.81 & 38.87 & 39.48 & 38.20 & 37.54 & 37.04 & 38.09 & 38.44 & 37.65 & 38.54 & 38.48 & 38.17 & 38.92 & 38.15 & 37.93 & 37.78 & 38.07 & 37.49 \\
\hline 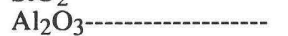 & 23.44 & 28.27 & 23.92 & 27.49 & 26.14 & 22.51 & 25.36 & 24.59 & 22.31 & 25.69 & 24.65 & 23.28 & 25.88 & 25.69 & 22.24 & 27.16 & 25.30 & 20.70 \\
\hline $\mathrm{TiO}_{2}$ & 0.34 & 0.09 & 0.13 & 0.045 & 0.10 & 0.00 & 0.04 & 0.03 & 0.02 & 0.03 & 0.03 & 0.12 & 0.00 & 0.07 & 0.21 & 0.04 & 0.12 & 0.05 \\
\hline $\mathrm{Fe}_{2} \mathrm{O}_{3}{ }^{1}$ & 12.66 & 7.70 & 10.46 & 8.11 & 11.00 & 14.25 & 10.92 & 11.33 & 13.70 & 9.74 & 11.44 & 13.04 & 9.21 & 10.48 & 13.49 & 8.77 & 10.17 & 16.25 \\
\hline $\mathrm{MgO}$ & 0.10 & 0.04 & 1.46 & 0.04 & 0.12 & 0.06 & 0.03 & 0.04 & 0.05 & 0.07 & 0.05 & 0.05 & 0.01 & 0.07 & 0.02 & 0.04 & 0.06 & 0.06 \\
\hline MnO--_- & 0.01 & 0.07 & 0.06 & 0.17 & 1.11 & 0.12 & 0.20 & 0.91 & 0.02 & 0.01 & 0.00 & 0.00 & 0.18 & 0.16 & 0.00 & 0.19 & 0.25 & 0.14 \\
\hline $\mathrm{CaO}$ & $\underline{23.19}$ & $\underline{23.57}$ & $\underline{22.71}$ & $\underline{23.87}$ & $\underline{22.12}$ & $\underline{23.52}$ & $\underline{23.14}$ & $\underline{22.48}$ & $\underline{23.72}$ & $\underline{23.60}$ & 23.23 & $\underline{23.33}$ & $\underline{23.53}$ & $\underline{23.10}$ & $\underline{23.69}$ & $\underline{23.70}$ & $\underline{23.48}$ & $\underline{23.16}$ \\
\hline Total---------------- & 97.55 & 98.61 & 98.22 & 97.92 & 98.13 & 97.50 & 97.78 & 97.82 & 97.47 & 97.68 & 97.88 & 97.89 & 97.73 & 97.72 & 97.58 & 97.68 & 97.45 & 97.85 \\
\hline
\end{tabular}

Number of atoms on the basis of 12.5 oxygens

\begin{tabular}{|c|c|c|c|c|c|c|c|c|c|c|c|c|c|c|c|c|c|c|}
\hline $\mathrm{Si}---$ & 3.01 & 3.00 & 3.09 & 2.98 & 2.96 & 2.98 & 3.01 & 3.04 & 3.02 & 3.03 & 3.04 & 3.03 & 3.05 & 3.01 & 3.04 & 2.97 & 3.01 & 3.02 \\
\hline Allv & 0.00 & 0.00 & 0.00 & 0.02 & 0.04 & 0.02 & 0.00 & 0.00 & 0.00 & 0.00 & 0.00 & 0.00 & 0.00 & 0.00 & 0.00 & 0.03 & 0.00 & 0.00 \\
\hline $\mathrm{Al}^{\mathrm{VI}} \mathrm{L}$ & 2.20 & 2.57 & 2.21 & 2.51 & 2.39 & 2.12 & 2.36 & 2.29 & 2.11 & 2.38 & 2.29 & 2.18 & 2.39 & 2.39 & 2.10 & 2.48 & 2.36 & 1.97 \\
\hline 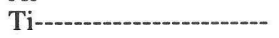 & 0.02 & 0.02 & 0.01 & 0.00 & 0.01 & 0.00 & 0.00 & 0.01 & 0.00 & 0.00 & 0.00 & 0.01 & 0.00 & 0.00 & 0.01 & 0.00 & 0.01 & 0.00 \\
\hline $\mathrm{Fe}^{3+}+$ & 0.76 & 0.45 & 0.62 & 0.48 & 0.65 & 0.86 & 0.65 & 0.67 & 0.83 & 0.58 & 0.68 & 0.78 & 0.54 & 0.62 & 0.81 & 0.52 & 0.61 & 0.99 \\
\hline 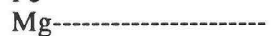 & 0.01 & 0.01 & 0.17 & 0.01 & 0.01 & 0.01 & 0.00 & 0.00 & 0.01 & 0.01 & 0.01 & 0.01 & 0.00 & 0.01 & 0.00 & 0.01 & 0.01 & 0.01 \\
\hline 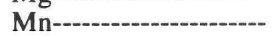 & 0.00 & 0.00 & 0.00 & 0.01 & 0.07 & 0.01 & 0.01 & 0.06 & 0.00 & 0.00 & 0.00 & 0.00 & 0.01 & 0.01 & 0.00 & 0.01 & 0.02 & 0.01 \\
\hline 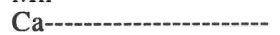 & 1.98 & 1.95 & 1.90 & 2.00 & 1.87 & 2.03 & 1.96 & 1.91 & 2.04 & 1.99 & 1.96 & 1.98 & 1.98 & 1.95 & 2.03 & 2.00 & 1.99 & 2.00 \\
\hline $\mathrm{Ps}^{2}----$ & 0.26 & 0.15 & 0.22 & 0.16 & 0.21 & 0.29 & 0.22 & 0.23 & 0.28 & 0.20 & 0.23 & 0.26 & 0.18 & 0.21 & 0.28 & 0.17 & 0.21 & 0.33 \\
\hline
\end{tabular}

${ }^{1}$ Total iron is given as $\mathrm{Fe}_{2} \mathrm{O}_{3}$.

${ }^{2} \mathrm{Ps}$ is pistacite component (in mole percent) determined by the calculation $\mathrm{Fe} / \mathrm{Fe}+\mathrm{Al}$. 
their titanite analyses as "some of the most Al-rich authigenic sphenes that have been described." Although the Mount Hood titanium-bearing mineral has not been demonstrated to be titanite, its chemical composition and mode of occurrence are quite similar to the "very fine grained xenoblastic aggregates" associated with epidote in the Cerro Prieto geothermal field (Schiffman and others, 1985). The Mount Hood titanite(?) has slightly higher $\mathrm{Al}_{2} \mathrm{O}_{3}$ and significantly higher $\mathrm{Fe}_{2} \mathrm{O}_{3}$ values than the titanite reported by Schiffman and others (1985). This appears to suggest that the substitution of $\mathrm{Al}$ and $\mathrm{Fe}^{3+}$ for $\mathrm{Ti}$ in the Mount Hood titanite(?) is more extreme than in the previous case.

\section{GARNET(?)}

A single subhedral dodecahedral(?) crystal from $79 \mathrm{~m}$ depth in drill hole 3 (table 1) was observed by SEM (fig. 18). Semiquantitative chemical analysis by EDS shows that the mineral contains abundant $\mathrm{Fe}, \mathrm{Ca}$, and $\mathrm{Si}$, as well as small amounts of $\mathrm{V}$ and Ti. The crystal morphology and chemistry suggest that the mineral may be andradite gar-

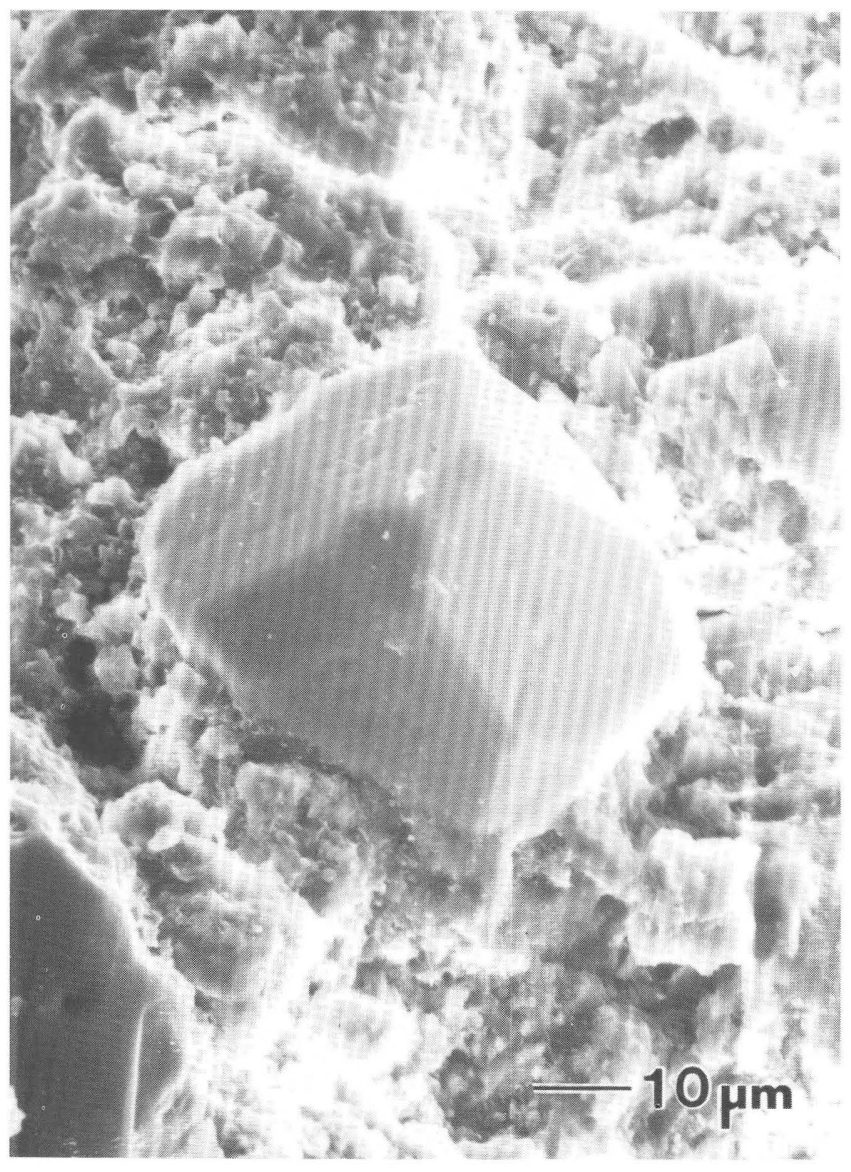

Figure 18. Scanning electron micrograph showing an imperfectly formed, trapezohedral garnet(?) crystal from about $79 \mathrm{~m}$ depth in the McGee Creek drill hole (table 1, No. 3). net. Low-temperature andradite and grossular garnet that formed in close association with earlier analcime and thomsonite were reported in Scottish Paleozoic lavas intruded by a Tertiary dike (Livingstone, 1989). According to Livingstone (1989), chemical conditions must have been favorable for the formation of the garnets at temperatures considerably below $300^{\circ} \mathrm{C}$. Also, heat generated by the intrusion was not sufficient to alter the preexisting zeolite minerals.

Possible garnet in drill hole 3 (table 1) is difficult to explain. The mineral was found in a Quaternary pyroxene andesite lava flow that appears to have been subjected only to recent very low temperature (measured temperature at $605 \mathrm{~m}$ depth was $60.0^{\circ} \mathrm{C}$ ), (Robison and others, 1982) hydrothermal alteration; other hydrothermal minerals identified in this sample include hematite, smectite, heulandite, dolomite, and manganoan calcite. If the crystal shown in figure 18 is garnet, it must have formed at higher temperatures than occur at the present time. One possible explanation is that the garnet(?)-bearing grain may have been part of a xenolith. Xenoliths containing garnet were found in andesitic lavas at higher elevations on the north side of Mount Hood.

\section{TRUSCOTTITE(?)}

One rounded cobble in Quaternary reworked debris from about 2,200 $\mathrm{m}$ elevation on the northeast slope of Mount Hood contains a surface coating of white to colorless botryoidal opal, some of which appears to have altered to chalcedony. Several broken botryoids have an interior of yellowish-white, radiating, lamellar crystals (fig. 19). X-ray diffraction analysis suggests that the lamellar crystals may be truscottite; however, EDS semiquantitative chemical analysis using an SEM shows some $\mathrm{Al}$ and about equal proportions of $\mathrm{K}$ and $\mathrm{Ca}$ in addition to $\mathrm{Si}$. Although truscottite is a calcium silicate hydrate mineral, significant $\mathrm{K}$ and $\mathrm{Al}$ have been reported in truscottite analyses from Yellowstone National Park (Bargar and Beeson, 1985).

\section{ACTINOLITE}

Drill holes 8, 9, and 10 (table 1) and several surface samples collected in the vicinity of the Laurel Hill intrusion contain pale-green acicular actinolite. Most of these samples consist of quartz diorite in which the hornblende has been recrystallized to actinolite or chlorite, as indicated by Wise (1969). A few samples from lavas of the Rhododendron Formation adjacent to the Laurel Hill intrusion contain actinolite that probably formed by replacement of pyroxene phenocrysts during contact metamorphism. Actinolite also formed as an open-space deposit with closely associated epidote and later zeolites. Electron-microprobe analyses of 
two open-space actinolite crystals are given in table 15 . The low total weight percent oxides may reflect nondetermination of alkalis and water.

\section{PREHNITE}

Prehnite is scarce in Mount Hood samples and was only detected by X-ray diffraction in drill cuttings from two drill holes (table 1, Nos. 5 and 7). In drill hole 5, white vein fillings or tan-green altered grains in drill cuttings of the Columbia River Basalt Group contain prehnite with laumontite, quartz, smectite, and chlorite. Prehnite was also identified in drill hole 7 , with hematite, epistilbite, mixed-layer chlorite-smectite, and laumontite, in wholerock X-ray diffraction analyses of late Tertiary(?) hornblende andesite. A few surface samples of open-space fracture fillings and dikes, from the Laurel Hill intrusion and a zone of mineralization near Iron Creek southeast of Mount Hood, contain prehnite in association with quartz, epidote, smectite, chlorite and pyrite. In only one sample was prehnite observed (by microscope) as equant white to colorless crystals deposited later than quartz crystals in a large open fracture or vug(?); prehnite more commonly occurs as lamellar crystals.

Fluid inclusions in quartz from the just mentioned sample were not analyzed; however, fluid inclusions from several nearby samples have mean homogenization temperatures between $250^{\circ}$ and $270^{\circ} \mathrm{C}$. Prehnite has been

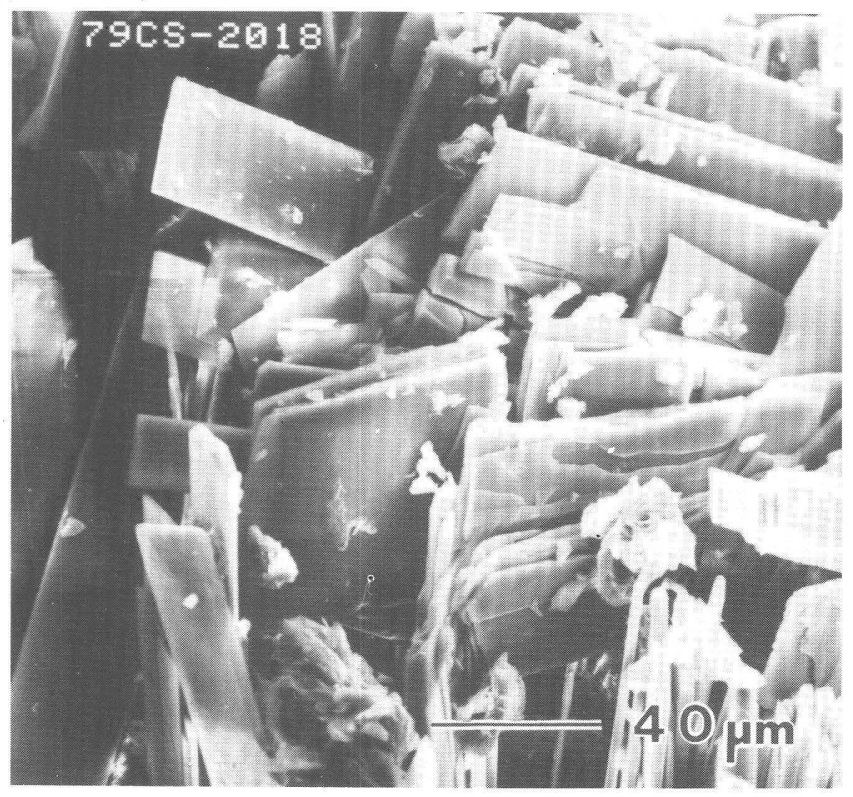

Figure 19. Scanning electron micrograph showing lamellar crystals of truscottite(?) deposited as radial concentrations on an erratic rock sample collected from about 2,200 m elevation on the northeast side of Mount Hood.
Table 15. Electron-microprobe analyses of actinolite from volcanic rocks of the Rhododendron Formation altered by the Laurel Hill intrusion.

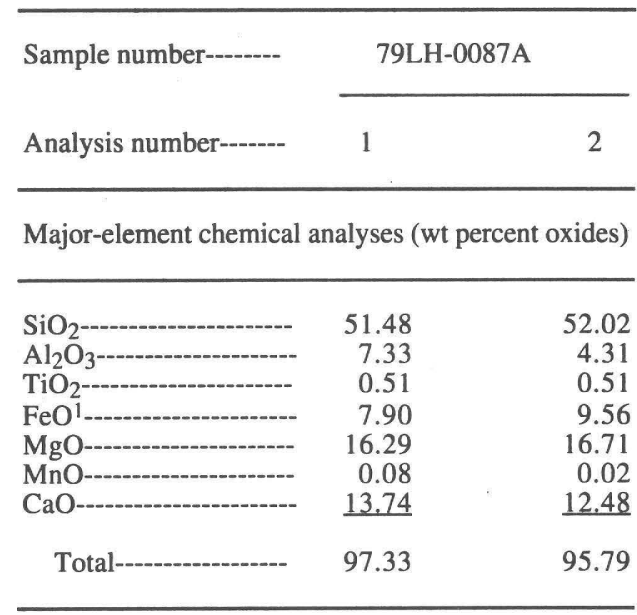

Number of atoms on the basis of 24 oxygens

\begin{tabular}{|c|c|c|}
\hline 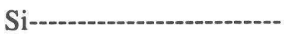 & 7.61 & 7.86 \\
\hline $\mathrm{Al}^{\mathrm{IV}}$ & 0.39 & 0.14 \\
\hline $\mathrm{Al}^{\mathrm{V}}$ & 0.89 & 0.63 \\
\hline 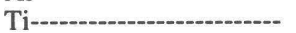 & 0.06 & 0.06 \\
\hline 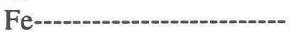 & 0.98 & 1.21 \\
\hline 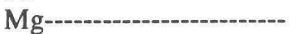 & 3.59 & 3.76 \\
\hline 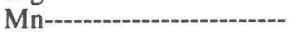 & 0.01 & 0.03 \\
\hline 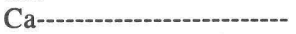 & 2.18 & 2.02 \\
\hline $100 \mathrm{Mg} / \mathrm{Mg}+\mathrm{Fe}^{2+}$ & 78.56 & 75.65 \\
\hline $\mathrm{Fe} /(\mathrm{Fe}+\mathrm{Mg})$ & 0.21 & 0.24 \\
\hline
\end{tabular}

${ }^{1}$ Total iron as $\mathrm{FeO}$.

found in drill holes of several geothermal areas where measured subsurface temperatures were between $250^{\circ}$ and $350{ }^{\circ} \mathrm{C}$ (Bird and others, 1984).

\section{ADULARIA}

A few outcrops of the Laurel Hill intrusion and a zone of extensive mineralization adjacent to Iron Creek on the southeast side of Mount Hood contain fractures coated by colorless to white (one sample is pink), euhedral adularia crystals (fig. 20) in association with earlier quartz crystals. Other secondary minerals in the samples include smectite, illite, chlorite, stilbite, epidote(?), and calcite. Chemical analyses of three of the samples (table 16) show that the adularia contains little or no $\mathrm{Ca}$ and $\mathrm{Na}$ and that its composition is uniform between crystals from different areas as well as within a single crystal.

Adularia can form by replacement of primary plagioclase phenocrysts, loss of $\mathrm{CO}_{2}$ and increase in $\mathrm{pH}$ during boiling of geothermal water, or introduction of significant potassium to the thermal water (Browne and Ellis, 1970). 
Table 16. Electron-microprobe analyses of adularia from near Mount Hood. [Dashed (--) where not analyzed]

\begin{tabular}{|c|c|c|c|c|c|c|c|c|c|}
\hline \multirow{2}{*}{$\begin{array}{l}\text { Sample number------- } \\
\text { Analysis number------ }\end{array}$} & \multicolumn{3}{|c|}{ 79LH-1057D } & \multicolumn{3}{|c|}{ 79IC-2032 } & \multicolumn{3}{|c|}{ 79IC-2033 } \\
\hline & 1 & 2 & 3 & 1 & 3 & 5 & 1 & 2 & 5 \\
\hline \multicolumn{10}{|c|}{ Major-element chemical analyses (wt percent oxides) } \\
\hline $\mathrm{SiO}_{2}$ & 64.33 & 63.58 & 63.52 & 63.65 & 64.22 & 64.79 & 64.16 & 64.51 & 64.96 \\
\hline $\mathrm{Al}_{2} \mathrm{O}_{3}$ & 18.41 & 18.36 & 18.58 & 18.33 & 18.54 & 18.27 & 17.95 & 18.50 & 17.47 \\
\hline $\mathrm{FeO}$ & 0.04 & 0.00 & 0.00 & 0.00 & 0.04 & 0.03 & 0.00 & 0.01 & 0.07 \\
\hline MgO-- & -- & -- & -- & 0.04 & 0.01 & 0.03 & 0.02 & 0.03 & 0.05 \\
\hline 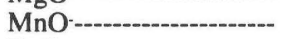 & -- & -- & -- & 0.00 & 0.00 & 0.00 & 0.01 & 0.00 & 0.00 \\
\hline $\mathrm{BaO}---$ & 0.36 & 0.63 & 0.24 & -- & -- & -- & -- & -- & -- \\
\hline $\mathrm{CaO}$ & 0.35 & 0.06 & 0.06 & 0.00 & 0.00 & 0.00 & 0.00 & 0.00 & 0.08 \\
\hline $\mathrm{Na}_{2} \mathrm{O}$ & 0.19 & 0.17 & 0.13 & 0.24 & 0.11 & 0.16 & 0.18 & 0.21 & 0.22 \\
\hline $\mathrm{K}_{2} \mathrm{O}$ & 15.57 & 16.06 & $\underline{16.12}$ & 16.05 & 16.15 & $\underline{16.22}$ & $\underline{16.21}$ & $\underline{16.21}$ & $\underline{15.79}$ \\
\hline Total--------------- & 99.25 & 98.86 & 98.65 & 98.31 & 99.07 & 99.50 & 98.53 & 99.47 & 98.64 \\
\hline
\end{tabular}

Number of atoms on the basis of 32 oxygens

\begin{tabular}{|c|c|c|c|c|c|c|c|c|c|}
\hline Si--. & 11.78 & 11.65 & 11.58 & 11.53 & 11.73 & 11.89 & 11.66 & 11.84 & 11.78 \\
\hline 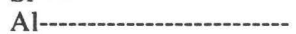 & 3.98 & 3.97 & 3.99 & 3.92 & 3.99 & 3.95 & 3.85 & 4.00 & 3.73 \\
\hline $\mathrm{Fe}-\mathrm{-}$ & 0.01 & 0.00 & 0.00 & 0.00 & 0.01 & 0.00 & 0.00 & 0.00 & 0.01 \\
\hline 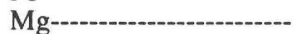 & -- & -- & -- & 0.01 & 0.00 & 0.01 & 0.01 & 0.01 & 0.01 \\
\hline 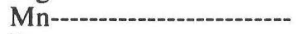 & -- & -- & -- & 0.00 & 0.00 & 0.00 & 0.00 & 0.00 & 0.00 \\
\hline 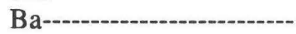 & 0.03 & 0.05 & 0.02 & -- & -- & -- & -- & -- & -- \\
\hline $\mathrm{Ca}--$ & 0.07 & 0.01 & 0.01 & 0.00 & 0.00 & 0.00 & 0.00 & 0.00 & 0.02 \\
\hline 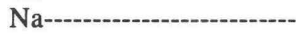 & 0.07 & 0.06 & 0.05 & 0.09 & 0.04 & 0.06 & 0.06 & 0.08 & 0.08 \\
\hline 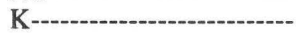 & 3.64 & 3.75 & 3.75 & 3.71 & 3.76 & 3.80 & 3.76 & 3.80 & 3.65 \\
\hline
\end{tabular}

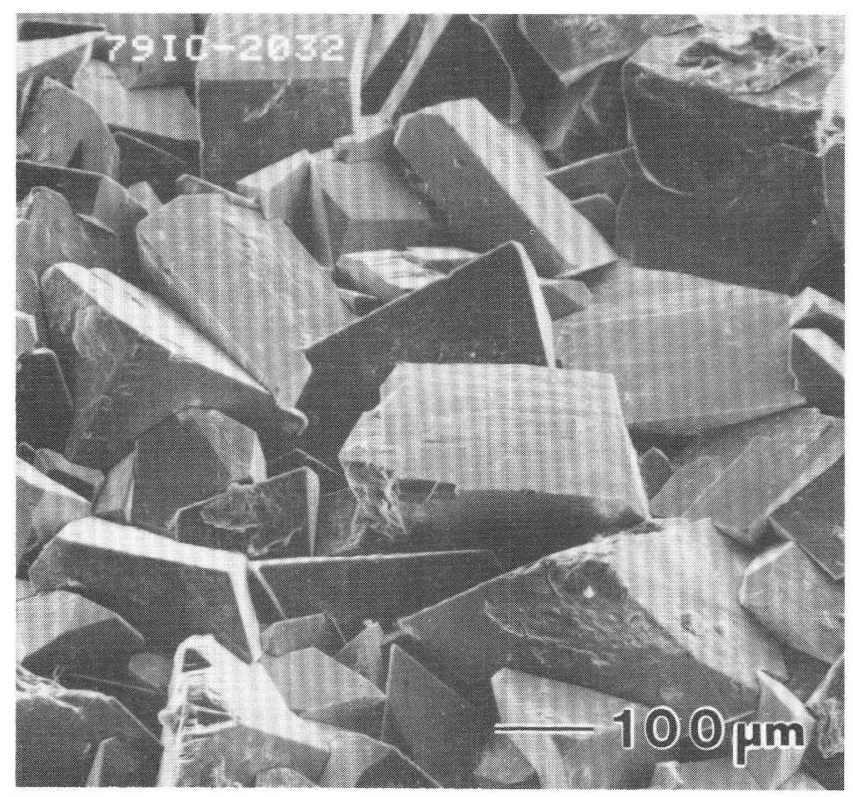

Figure 20. Scanning electron micrograph showing euhedral, equant adularia crystals from fracture fillings in Tertiary volcanic breccia near Iron Creek on the southeast side of Mount Hood.
The Mount Hood adularia does not replace plagioclase and fluid inclusions in the earlier formed quartz do not indicate that boiling occurred either during crystal formation or at a later time; probably the adularia formed because of potassium-rich thermal water that flowed through fracture systems.

\section{TOURMALINE AND APATITE}

One surface sample of the Laurel Hill intrusion has a fracture coating consisting of radiating sprays of black, columnar tourmaline crystals (fig. 21). SEM semiquantitative chemical analyses by EDS show that the constituents are $\mathrm{Si}, \mathrm{Al}, \mathrm{Fe}$, and minor $\mathrm{Mg}$ and $\mathrm{Ca}$. Tiny, white needles of apatite, identified by $\mathrm{X}$-ray diffraction, are intergrown with the tourmaline crystals. The fracture also has a late finegrained coating of smectite and stilbite; hornblende crystals mostly are altered to chlorite. Coexisting titanite(?) (discussed above) was also tentatively identified on the basis of high Ti content (determined by SEM methods).

\section{COPPER MINERALS}

A single grain from drill cuttings in Quaternary reworked volcanic debris at $121.9 \mathrm{~m}$ depth in drill hole 7 
(table 1) contains four crystals of native copper (copper was confirmed by EDS). Generally, the copper crystals have a rounded morphology and appear to have an oxide(?) coating (fig. 22). The surface of one crystal displays parallel striations and another copper crystal is somewhat flattened. Panned concentrates of stream-sediment samples collected upstream from the drill hole 7 site have copper values that are much higher than background values for copper at Mount Hood (Keith and others, 1980).

A few surface samples from the Laurel Hill intrusion contain open-space fillings of bluish green chrysocolla. Figure 8 shows a thin botryoidal chrysocolla crust that formed later than chabazite on a fracture surface; other minerals identified from this fracture include iron oxide, smectite, chlorite, wairakite, epistilbite, and stilbite.

\section{FLUID INCLUSIONS}

Hydrothermal quartz crystals occur in several outcrop samples collected close to intrusions near Mount Hood, as well as in drill holes that penetrated these plutons. The

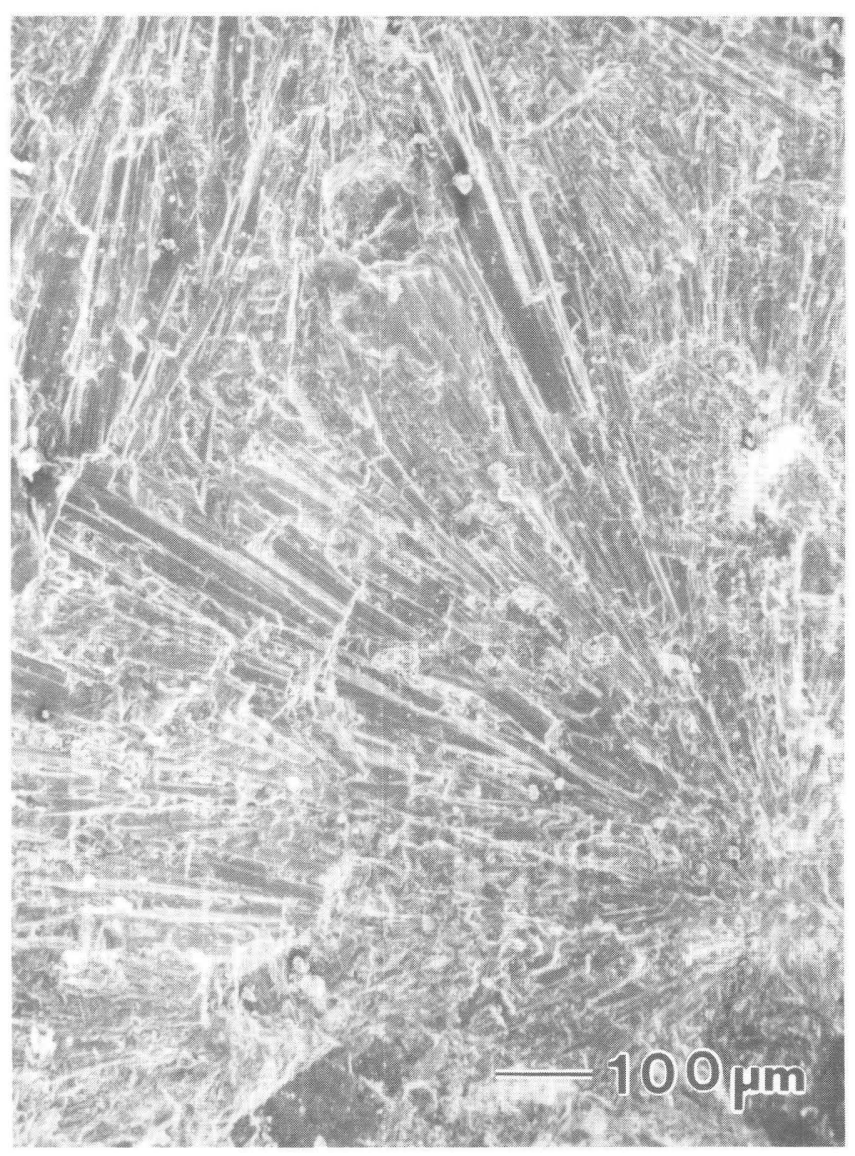

Figure 21. Scanning electron micrograph showing radiating sprays of acicular tourmaline crystals in a lava flow of the Rhododendron Formation intruded by the Laurel Hill intrusion. plutons and the rocks they intrude are of late Tertiary age and are not related to the presently active geothermal system at Mount Hood. An examination of fluid inclusions in these secondary quartz crystals was included in this study to obtain an idea of temperatures and fluid salinities. involved with hydrothermal alteration observed in drill-hole and outcrop specimens. Fluid-inclusion homogenization temperature $\left(\mathrm{T}_{\mathrm{h}}\right)$ and final melting-point temperature $\left(\mathrm{T}_{\mathrm{m}}\right)$ data, determined by the freezing method (Roedder, 1962), were obtained for 16 sample chips from 6 double-polished, hydrothermal quartz samples (table 17). Fluid-inclusion heating/freezing measurements were made on fluid inclusions in quartz collected from a drill-cuttings sample (specimen SC-170-3) at $51.8 \mathrm{~m}$ depth in the Still Creek drill hole (table 1, No. 10) and from outcrop samples near the Laurel Hill intrusion (specimens 79CCQ-0088F\&O). Fluid-inclusion data were also obtained for quartz associated with an intrusion southeast of Mount Hood near Iron Creek (specimens 79IC-20390 and 79IC-2040) and an outcrop (specimen 79WR-2010) $\sim 3 \mathrm{~km}$ northwest of this intrusion. (The Iron Creek intrusion was probably responsible for the mineralization observed in several kilometers of road cuts on the southeast flank of Mount Hood). A total of $279 \mathrm{~T}_{\mathrm{h}}$ measurements and $58 \mathrm{~T}_{\mathrm{m}}$ values were obtained initially using a Chaixmeca heating/freezing stage and later a Linkam THM 600 heating/freezing stage with a TMS 90 temperature control system.

The majority of fluid inclusions located in samples near the Laurel Hill and Still Creek intrusions are liquid rich (fig. 23), with a vapor bubble that usually constitutes

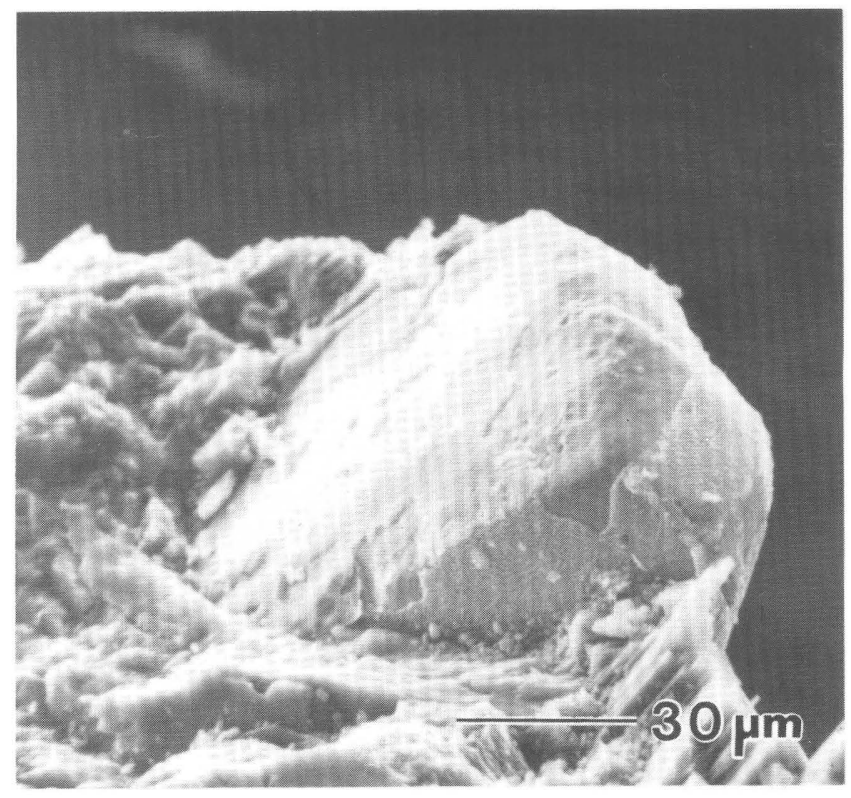

Figure 22. Scanning electron micrograph showing a grain of native copper from $121.9 \mathrm{~m}$ depth in drill hole 7 (table 1) that appears to be coated by a thin oxide(?) layer. 
about 10 to 30 percent of the volume of the inclusion. These inclusions, ranging in size from $<10$ to $\sim 100 \mu \mathrm{m}$, formed along healed fractures and appear to be secondary, although a pseudosecondary origin (formed along healed fractures prior to a later quartz deposit that covers the exterior of the crystal) is possible for some of the fluid inclusions. A few monophase-liquid, monophase-vapor, or vapor-rich fluid inclusions appear to be closely related and may have formed by necking down (Bodnar and others, 1985). Necking down refers to a process whereby quartz is dissolved and redeposited, changing the shape of the fluid inclusions with time. During this process large fluid inclusions can be divided into several smaller inclusions; some of these smaller fluid inclusions may contain only a single phase (vapor or liquid) whereas others contain both vapor and liquid. An example of necking down is marked by an arrow in figure 24. A discontinuous, healed fracture in specimen 79CCQ-0088F consists entirely of small, pseudosecondary, monophase-vapor fluid inclusions that have a negative-crystal shape; these fluid inclusions along with occasional, large, isolated, negative-crystal inclusions filled by monophase vapor (fig. 25) may have formed at an early stage in the growth of the crystal and possibly are due to boiling conditions or effervescence as discussed in Roedder (1984).

Fluid inclusions in quartz samples collected near the intrusion at Iron Creek consist mostly of secondary, liquidrich inclusions (fig. 24) that range in size from $<10$ to $\sim 100 \mu \mathrm{m}$ and contain about 10 to 30 percent vapor. A few liquid- and vapor-rich fluid inclusions are as much as 294 $\mu \mathrm{m}$ in size, appear to be isolated or unrelated to other fluid inclusions in the crystals, and may be of primary origin (fig. 26). A few closely associated vapor-rich and monophase-liquid fluid inclusions appear to be the result of necking down. Large, isolated, monophase-gas fluid inclusions and healed fractures containing monophase-gas inclusions, both with negative-crystal shapes, probably formed due to boiling or effervescence. Some healed fractures in specimen 79IC-2040 contain vapor-rich, secondary fluid inclusions (fig. 27) (vapor constitutes $\sim 50$ to 80 percent of inclusion volume) in association with the dominant liquid-rich inclusions. Three of these vapor-rich fluid inclusions homogenized (to the vapor state) near the critical temperature for pure $\mathrm{H}_{2} \mathrm{O}\left(374.1^{\circ} \mathrm{C}\right)$; these $\mathrm{T}_{h}$ values are somewhat higher than the $T_{h}$ for liquid-rich fluid inclusions (fig. 28).

Fluid-inclusion salinities in three quartz samples (table 17) are quite low, $\sim 0.0$ to 0.4 weight percent $\mathrm{NaCl}$ equivalent. Several fluid inclusions in another sample have a salinity of about 2.4 weight percent $\mathrm{NaCl}$ equivalent, and another sample contains fluid inclusions with quite variable salinities ranging from 0.0 to 5.8 weight percent $\mathrm{NaCl}$ equivalent. Plotting $T_{h}$ vs $T_{m}$ (fig. 29) shows two possible trends. A vertical trend at $\mathrm{T}_{\mathrm{m}}$ value $0^{\circ} \mathrm{C}$ shows simple cooling of very low salinity water present in the majority of the fluid inclusions analyzed; another vertical trend occurs at $\mathrm{T}_{\mathrm{m}}$ values of $-1.4^{\circ}$ and $-1.9^{\circ} \mathrm{C}$. A second, less pronounced, essentially horizontal trend (at $\sim 270^{\circ} \mathrm{C}$ ) that also appears to be present in figure 29 may suggest isothermal mixing of waters having different salinities.

Figure 28 shows six histograms of $T_{h}$ data for fluid inclusions from the six quartz sample locations included in this study. The tabulated data (table 17) give the $T_{h}$ ranges and mean $T_{h}$ values for all 16 quartz chips analyzed from these six sample sites. The fluid inclusions in quartz crystals associated with the Laurel Hill, Still Creek, and Iron Creek intrusions all have mean $T_{h}$ measurements between $251^{\circ}$ and $273^{\circ} \mathrm{C}$. Specimen $79 \mathrm{WR}-2010$, which was collected about $3 \mathrm{~km}$ closer to Mount Hood than the Iron Creek intrusion samples, has a mean $\mathrm{T}_{\mathrm{h}}$ of $229^{\circ} \mathrm{C}$.

One intriguing result of the fluid-inclusion study is that one of the specimens (79IC-2039O) was found to have a few hydrothermal quartz crystals that contain from 1 to $\sim 4$ or 5 tiny $(\sim 1 \mu \mathrm{m}$ sized) moving particles that appear to have a threadlike or rodlike shape. These moving particles apparently were trapped inside at least eight of the fluid inclusions at the time the fluid inclusions formed. Two of these liquid-rich, secondary fluid inclusions homogenized at $250^{\circ}$ and $258^{\circ} \mathrm{C}$; melting-point temperatures were not determined for these two fluid inclusions, but six other fluid inclusions in the same sample all had $\mathrm{T}_{\mathrm{m}}$ values of $0.0^{\circ} \mathrm{C}$. Similar-sized and -shaped moving particles have been reported from fluid inclusions in hydrothermal quartz crystals that formed in fractures in a 150-ka rhyolite lava flow penetrated by a U.S. Geological Survey research drill hole in Lower Geyser Basin, Yellowstone National Park, Wyoming (Bargar and others, 1985). Homogenization temperatures for the Yellowstone fluid inclusions were between $190^{\circ}$ and $280^{\circ} \mathrm{C}$. The Yellowstone moving particles (movement of the particles appears to be due to Brownian motion) are hypothesized to be bacteria. If the particles are eventually proven to be bacteria, they would be very significant because they must have lived at far hotter temperatures than is believed possible for present-day bacteria. Baross and Deming (1983) reported thermophilic bacteria living in $350^{\circ} \mathrm{C}$ waters of a sea-floor hot spring at $21^{\circ} \mathrm{N}$. latitude on the East Pacific Rise; however, the results of this study have been disputed (Trent and others, 1984). Presently, the upper temperature limit for life to exist is not known but is thought to be between $110^{\circ}$ and about $200^{\circ} \mathrm{C}$ (Brock, 1985).

\section{DISCUSSION}

Our study of drill-hole and outcrop samples in the Mount Hood area found numerous metamorphic minerals that are believed to have formed by hydrothermal alteration at low to moderate temperatures. Such metamorphic mineral assemblages are described as "very low grade 
Table 17. Fluid-inclusion heating/freezing data for hydrothermal quartz crystals from drill holes and outcrops near Mount Hood. [Dashed (--) where not analyzed]

\begin{tabular}{|c|c|c|c|c|c|c|c|c|}
\hline Sample number ${ }^{1}$ & Locality ${ }^{2}$ & $\begin{array}{l}\text { Associated } \\
\text { secondary } \\
\text { minerals }^{3}\end{array}$ & $\begin{array}{l}\text { Number of melting- } \\
\text { point temperature } \\
\text { measurements }\end{array}$ & $\begin{array}{c}\text { Melting-point } \\
\text { temperatures } \\
\mathrm{T}_{\mathrm{m}}\left({ }^{\circ} \mathrm{C}\right)^{4}\end{array}$ & $\begin{array}{l}\text { Salinity } \\
\text { (wt percent } \\
\text { NaCl equiv.) }\end{array}$ & $\begin{array}{l}\text { Number of homo- } \\
\text { genization temper- } \\
\text { ature measurements }\end{array}$ & $\begin{array}{c}\text { Range of } \\
\text { homogenization } \\
\text { temperatures } \\
\mathrm{T}_{\mathrm{h}}\left({ }^{\circ} \mathrm{C}\right)^{4}\end{array}$ & $\begin{array}{c}\text { Mean } \\
\text { homogenization } \\
\text { temperature } \\
\mathrm{T}_{\mathrm{h}}\left({ }^{\circ} \mathrm{C}\right)^{4}\end{array}$ \\
\hline $79 \mathrm{CCQ}-0088 \mathrm{~F}$ & 1 & $\mathrm{Ep}, \mathrm{Mt}, \mathrm{Sm}, \mathrm{St}, \mathrm{He}$ & 7 & -1.4 & 2.4 & 29 & $192-320$ & 270 \\
\hline 79CCQ-0088O & 1 & $\mathrm{Ep}, \mathrm{Mt}, \mathrm{Ch}, \mathrm{Sm}, \mathrm{Sc}, \mathrm{St}$ & 6 & +0.1 & 0.0 & 28 & $213-346$ & 258 \\
\hline SC-170-3 & 2 & $\mathrm{La}, \mathrm{Ep}, \mathrm{Ca}, \mathrm{Ch}$ & 2 & -0.2 & 0.4 & 21 & $212-324$ & 273 \\
\hline 79WR-2010 & 3 & $\mathrm{Cc}, \mathrm{I}, \mathrm{Ch}, \mathrm{Py}, \mathrm{Cl}$ & 0 & -- & -- & 38 & $193-330$ & 229 \\
\hline 79IC-20390 & 4 & $\mathrm{Ep}, \mathrm{Ch}$ & 20 & variable, 0.0 to -3.6 & 0.0 to 5.8 & 68 & $151-315$ & 251 \\
\hline 79IC-2040 & 4 & Ad & 23 & 0.0 & 0.0 & 95 & $159-373$ & 272 \\
\hline
\end{tabular}

'Sample SC-170-3 is from $51.8 \mathrm{~m}$ depth in the Still Creek drill hole (table 1, No. 10); remaining samples are from outcrops.

${ }^{2}$ Localities (see fig. 1) are: 1 = Laurel Hill, $2=$ Still Creek, $3=$ Barlow Pass-Bennett Pass area, and $4=$ Iron Creek

${ }^{3}$ Mineral abbreviations are: $\mathrm{Ad}=$ adularia, $\mathrm{Cc}=$ calcite, $\mathrm{Ca}=$ chabazite, $\mathrm{Cl}=$ chalcedony, $\mathrm{Ch}=$ chlorite, $\mathrm{Ep}=$ epidote, $\mathrm{He}=$ heulandite, $\mathrm{I}=$ illite, $\mathrm{La}=$ laumontite, $\mathrm{Mt}=$ magnetite, $\mathrm{Sc}=$ scolecite, $\mathrm{Sm}=$ smectite, and $\mathrm{St}=$ stilbite.

${ }^{4}$ Multiple calibration measurements, using synthetic fluid inclusions (Bodnar and Sterner, 1984) and chemical compounds with known melting-point temperatures recommended by Roedder (1984), suggest that the $\mathrm{T}_{\mathrm{m}}$ measurements should be accurate to within $\pm 0.2^{\circ} \mathrm{C}$, and that the $\mathrm{T}_{\mathrm{h}}$ values should be accurate to better than $\pm 2.0^{\circ} \mathrm{C}$. 
metamorphism" by Frey and Kisch (1987), who used the term to refer to metamorphism that takes place in the temperature range of about $150^{\circ}$ to $200^{\circ}$ through $350^{\circ}$ to $400^{\circ} \mathrm{C}$. Mineral assemblages occurring in this temperature range include "zeolite facies" minerals, which formed at the lower temperatures, and "greenschist facies" minerals, which were produced at the higher temperatures (Liou and others, 1987). Also present are several subgreenschist-facies mineral assemblages (Liou and others, 1987). The distinction between very low grade metamorphism and diagenesis is uncertain because definitions of diagenesis are ambiguous; Frey and Kisch (1987) indicated that such distinctions probably are not of great importance.

Liou and others (1987) discussed five types of very low grade metamorphism: ocean floor, burial, subduction, thermal, and hydrothermal. Hydrothermal metamorphism best describes most alteration mineralogy observed in the Mount Hood area; however, thermal metamorphism does occur in rocks adjacent to intrusions. Wise (1969) described a hornblende hornfels zone (thermal halo) about 60 -m thick at the west end of the Still Creek intrusion.

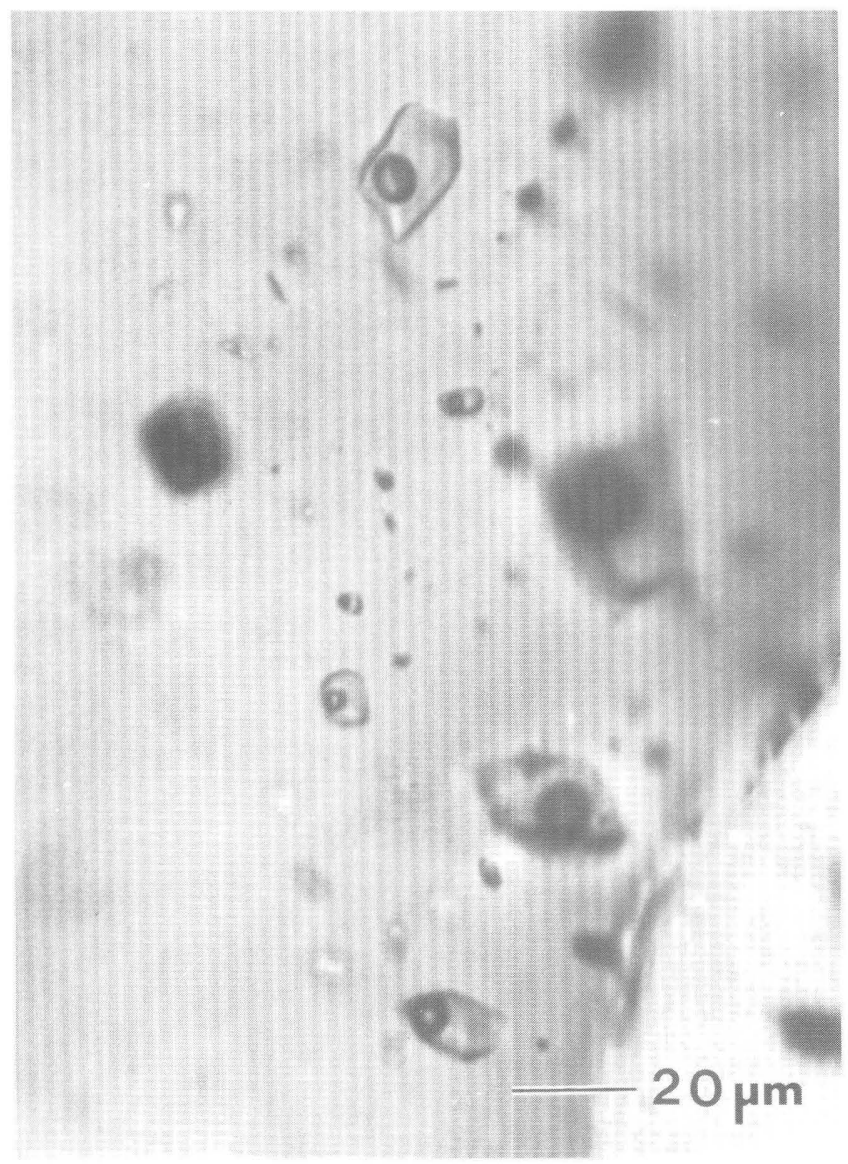

Figure 23. Photomicrograph showing liquid-rich, secondary fluid inclusions in hydrothermal quartz from a fracture in an outcrop of the Rhododendron Formation (specimen 79CCQ-0088F) altered by the Laurel Hill intrusion.

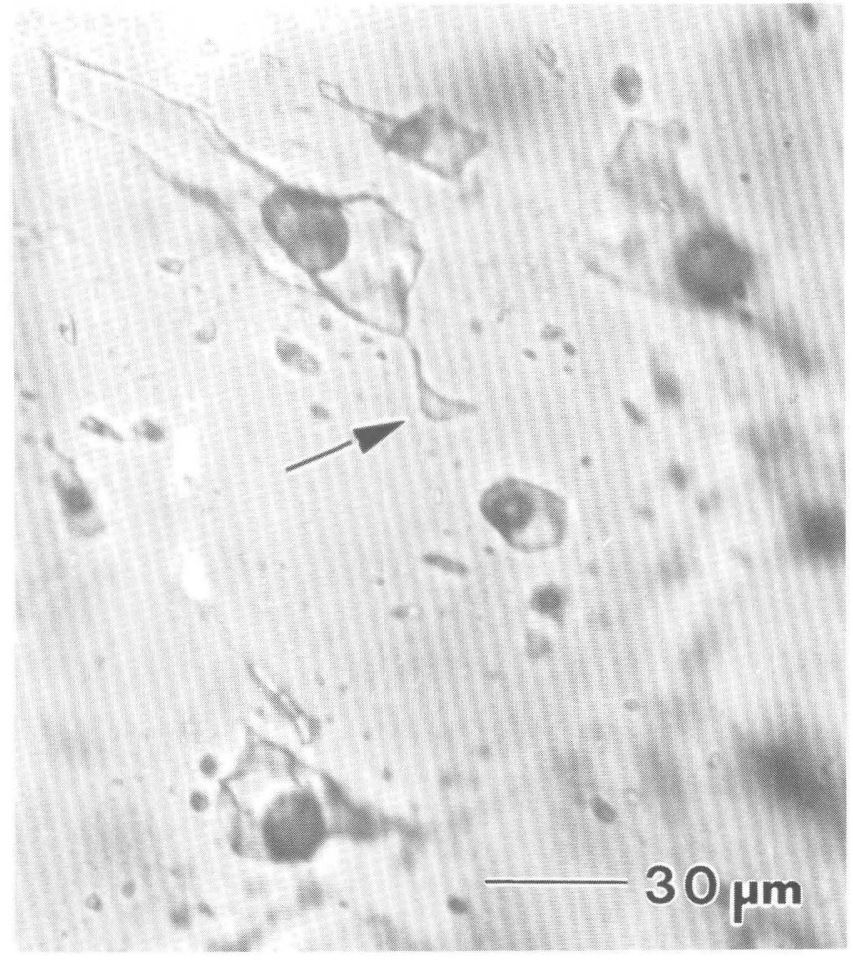

Figure 24. Photomicrograph showing secondary, liquid-rich fluid inclusions in a hydrothermal quartz crystal that was deposited in open space of a Tertiary volcanic breccia (specimen 79IC2040) intruded by a pluton near Iron Creek to the southeast of Mount Hood. The arrow points to a small monophase-liquid necked-down fluid inclusion.

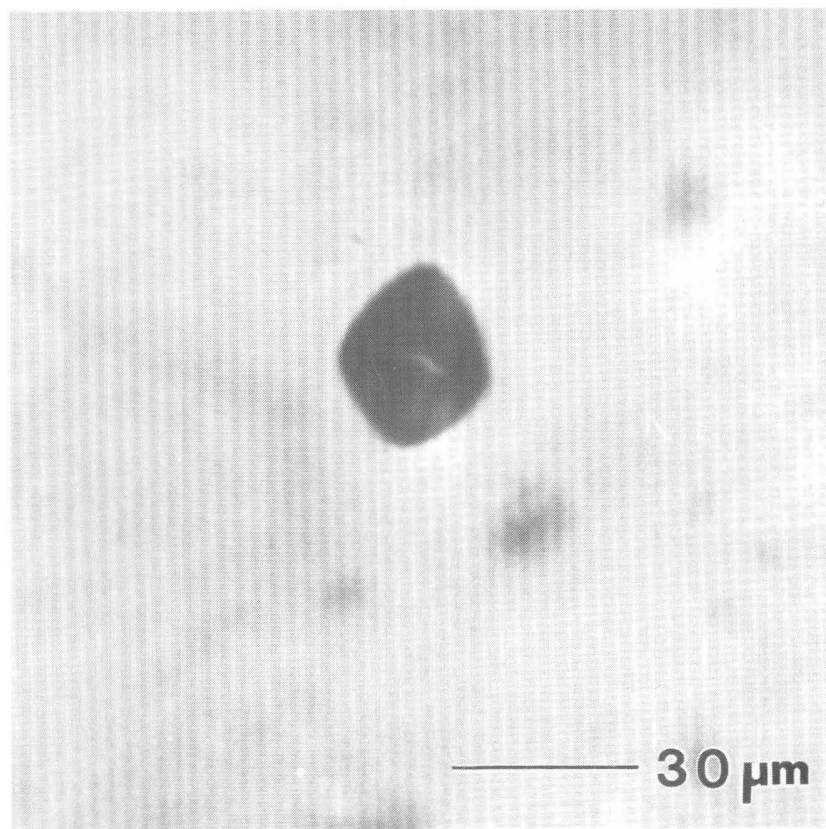

Figure 25. Photomicrograph showing an isolated, monophasevapor fluid inclusion having a negative crystal shape (specimen 79CCQ-0088F). 
Similar thermal halos in country rocks surrounding intrusions can experience temperature ranges (higher than $400^{\circ} \mathrm{C}$ ) characteristic of low- to high-grade metamorphism and can result in the formation of zeolite minerals such as wairakite and laumontite (Liou and others, 1987). Beaufort and others (1990) described fractures containing several alteration minerals, including tourmaline and apatite, from a fossil hydrothermal system at Saint Martin, Lesser Antilles; studies of fluid inclusions in miarolitic quartz from these rocks indicate that quartz crystals formed at temperatures ranging from near $340^{\circ} \mathrm{C}$ to more than $510^{\circ} \mathrm{C}$. In the Mount Hood area, closely associated tourmaline and apatite line a fracture in one very altered sample obtained from a quarry in which exposures of the Laurel Hill intrusion can be seen; these minerals were probably formed by thermal metamorphism, possibly at temperatures above $400^{\circ} \mathrm{C}$.

\section{TERTIARY METAMORPHISM}

\section{GREENSCHIST- AND SUBGREENSCHIST-FACIES METAMORPHISM}

On the southwest side of Mount Hood, near the base of the mountain, are quartz diorite to quartz monzonite outcrops of the Laurel Hill and Still Creek intrusions. Wise (1969) indicated that the two intrusions may actually be part of a single larger stock. Similar hornblende-quartz microdiorite sills and dikes(?) were identified in the Old Maid Flat 1 and 7A (Priest and Vogt, 1982) drill holes (northwest side of Mount Hood). According to K-Ar dating, summarized in Priest and others (1982), and supplemented by data from Keith and others (1985), these smaller intrusive units may be correlative with the larger Laurel Hill and Still Creek intrusions; K-Ar dates all range from about $8.0 \pm 0.6 \mathrm{Ma}$ to $11.6 \pm 1.2 \mathrm{Ma}$. Bikerman (1970)

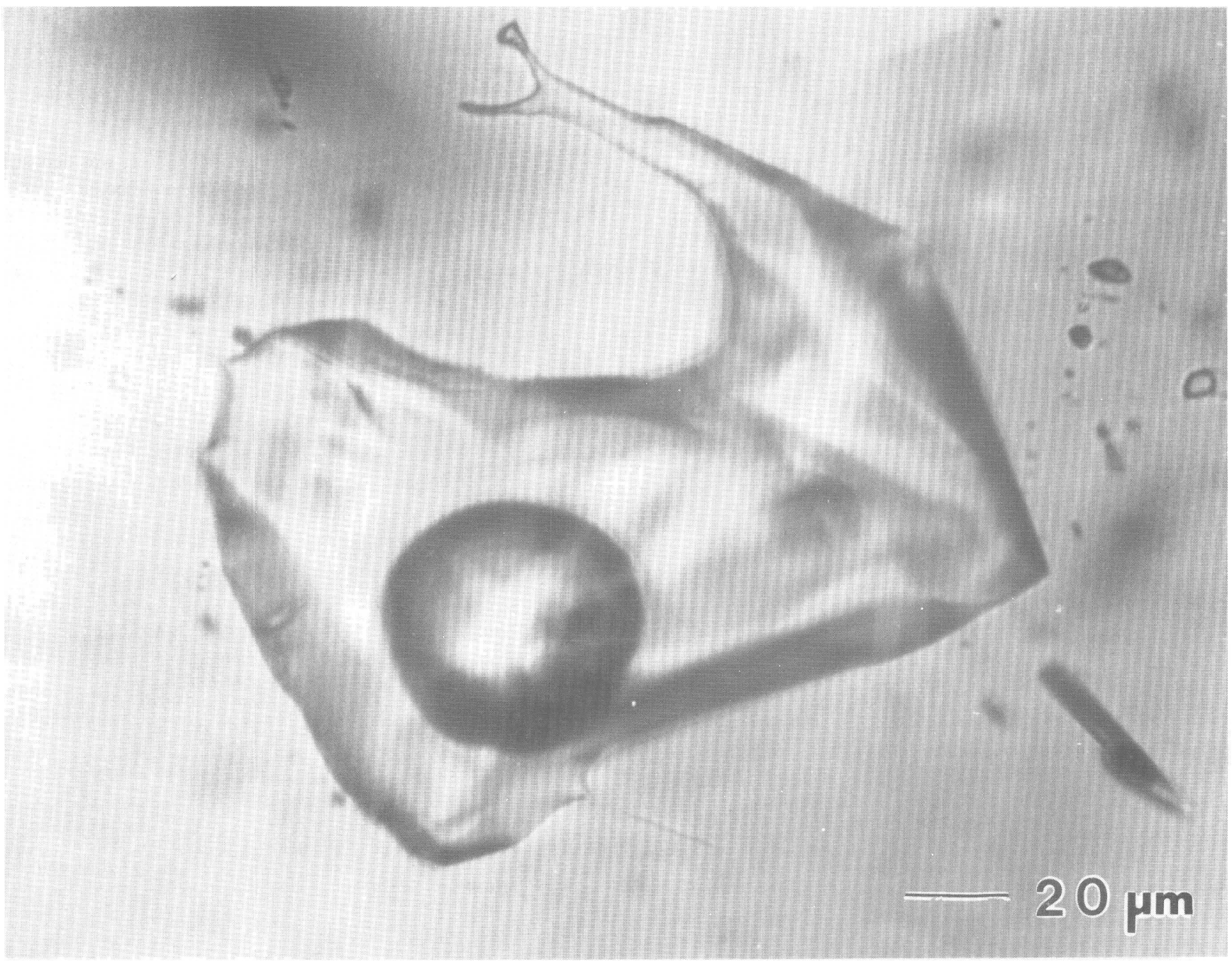

Figure 26. Photomicrograph showing a large, relatively saline (4.5 wt percent $\mathrm{NaCl}$ equivalent), primary(?), liquid-rich fluid inclusion from a hydrothermal quartz crystal that was deposited on a fracture in a Tertiary lava flow (specimen 79IC-20390) intruded by the pluton near Iron Creek. 
reported a $\mathrm{K}$-Ar date of $5.0 \pm 1.0 \mathrm{Ma}$ for an andesite dike that intrudes the Laurel Hill intrusion. Another dike, dated at about 5.26 $\pm 0.44 \mathrm{Ma}$ (Keith and others, 1985), occurs to the southeast of Mount Hood near Iron Creek. Geophysical evidence suggests the presence of an intrusive body in the area of Iron Creek (Goldstein and others, 1982). From these age data, there appear to have been at least two periods of intrusion in the Mount Hood area during late Miocene and early Pliocene time.

During late cooling stages, both the intrusive rocks and the margins of the intruded volcanic rocks would be expected to form alteration minerals over a wide temperature range. Alteration minerals such as tourmaline, epidote, quartz, chlorite, magnetite, and pyrite, encountered in association with small intrusive bodies throughout the Western Cascade Range of Oregon, were thought by Peck and others (1964) to have formed by contact metamorphism (thermal metamorphism of Liou and others (1987)). Peck and others (1964) also included these same minerals (except for tourmaline), in addition to chalcedony, carbonate minerals (calcite?), celadonite, and alkali-feldspar (adularia?), in their list of propylitic alteration (hydrothermal alteration) minerals found in Oregon's Western Cascade Range. A few outcrop and drill-hole cuttings samples included in our study consist of late Miocene to early Plio-

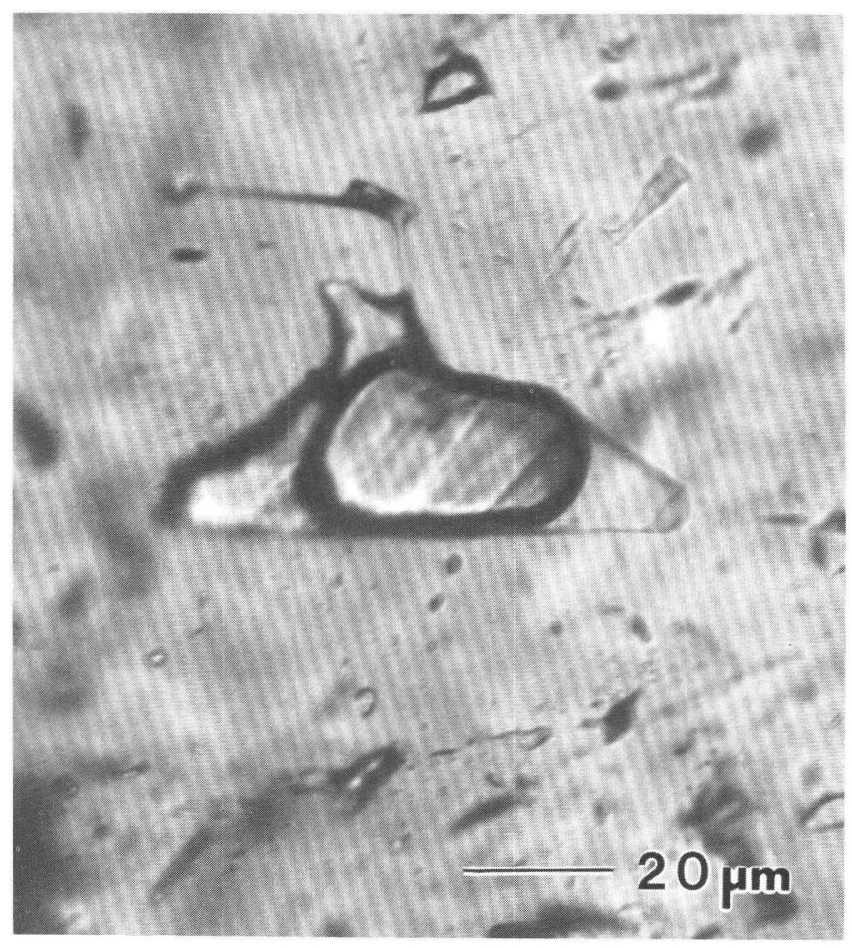

Figure 27. Photomicrograph showing a large, primary(?), vapor-rich fluid inclusion in hydrothermal quartz from a Tertiary volcanic breccia (specimen 79IC-2040) intruded by the pluton near Iron Creek. The melting-point temperature of this fluid inclusion is $0.0^{\circ} \mathrm{C}$ and the homogenization temperature measurement is $372.2^{\circ} \mathrm{C}$; the fluid inclusion homogenized to the vapor state. cene intrusive rocks (Laurel Hill intrusion, Still Creek intrusion, and Iron Creek intrusion) and intruded late Tertiary lava flows and volcaniclastic debris units; these samples contain the same minerals as listed in Peck and others (1964) plus several others (wairakite, actinolite, prehnite, and adularia) that formed by hydrothermal processes near cooling intrusions. Fluid-inclusion studies of hydrothermal quartz crystals, from fractures associated with small late Tertiary intrusions, yielded $T_{h}$ values that mostly fell in the range of about $250^{\circ}$ to $300^{\circ} \mathrm{C}$ (fig. 28 and table 17). The fluid-inclusion studies indicate that these quartz crystals and associated hydrothermal minerals formed at temperatures consistent with subgreenschist- to greenschistfacies metamorphism. In the Mount Hood area, such metamorphism was only identified near intrusions and was not found to be of regional extent. If hydrothermal alteration produced by subgreenschist- to greenschist-facies temperatures currently occurs at Mount Hood, it would probably only be found at considerable depth in association with cooling dikes, sills, or a larger solidified magma body.

Sparse native copper and chrysocolla were located near Mount Hood (appendix B). Ore-bearing minerals including chalcopyrite, sphalerite, galena, anglesite, and cerussite occur in quartz and carbonate veins that are found in association with late Tertiary intrusions in the Mount Hood area (Keith and Causey, 1982). Similar silver- and goldbearing epithermal vein deposits have been reported in association with other small late Miocene intrusions of the Western Cascade Range (Callaghan and Buddington, 1938; Peck and others, 1964). At all these locations sulfide minerals probably formed at greenschist to subgreenschist temperatures, but the carbonate and sulfate deposits, as well as copper and chrysocolla, were produced later at the lower temperatures associated with oxidized zones.

The Old Maid Flat 7A geothermal drill hole on the northwestern side of Mount Hood encountered Eocene(?) greenstone between depths of about $1,725 \mathrm{~m}$ and the bottom of the drill hole at 1,837 m (Priest and others, 1982). According to Holdaway and Bussey (1982), these rocks underwent greenschist metamorphism at temperatures of about $300^{\circ} \pm 50^{\circ} \mathrm{C}$, which produced chlorite, calcite, albite, and quartz mineralization. Most drill holes included in our study are much shallower than the Old Maid Flat 7A drill hole, and similar metavolcanic greenstone deposits were not encountered.

\section{ZEOLITE-FACIES METAMORPHISM}

Most drill holes and outcrop locations in this study contain one or more zeolite minerals. Studies of active geothermal areas, such as the low- to high-temperature Icelandic geothermal areas, indicate that zeolite minerals can form over a wide temperature range extending from very low temperatures $\left(\sim 50^{\circ} \mathrm{C}\right)$ to more than $200^{\circ} \mathrm{C}$ 
(Kristmannsdóttir and Tómasson, 1978). On the basis of these Icelandic hydrothermal alteration mineral studies, Kristmannsdóttir (1982) showed the temperature range for zeolite-facies metamorphism to be between about $50^{\circ}$ and $200^{\circ} \mathrm{C}$. Comparing the zeolite minerals identified in the Mount Hood area with the zeolite zones of Kristmannsdóttir and Tómasson (1978) suggests that (1) chabazite probably crystallized at the lower end of the zeolite-facies temperature range; (2) epistilbite, heulandite, mordenite, scolecite, and stilbite, and possibly ferrierite, harmotome, and stellerite(?) could have formed at intermediate temperatures in the range of $\sim 70^{\circ}$ to $150^{\circ} \mathrm{C}$; and (3) laumontite and wairakite probably were stable at high zeolite-facies temperatures to low subgreenschist-facies temperatures, although laumontite has been reported precipitating from $43^{\circ} \mathrm{C}$ waters (McCulloh and others, 1981).

Hydrothermal carbonate minerals (dolomite, calcite, manganoan calcite, rhodochrosite, and siderite), clay minerals ( smectite, illite, chlorite, mixed-layer illite-smectite, and mixed-layer chlorite-smectite), hematite, and titanite(?) are found in late Tertiary and Quaternary rocks from several drill holes and outcrops in the Mount Hood area. Some of these minerals, such as calcite and chlorite, can form over a wide temperature range extending through both zeolite-facies and greenschist-facies temperatures, whereas other minerals, such as smectite, dolomite, and the mixed-

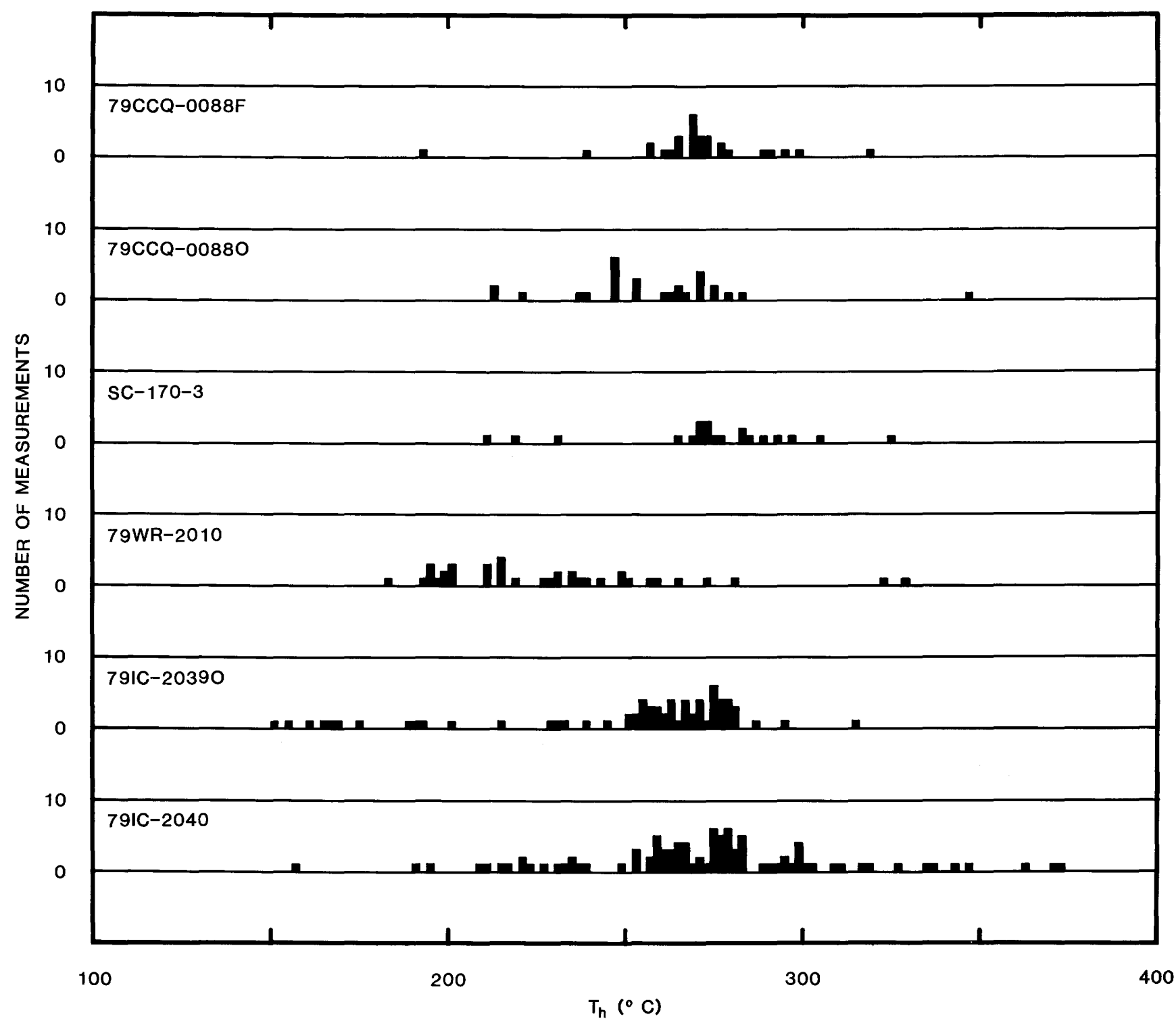

Figure 28. Histograms of fluid-inclusion homogenization temperatures of six hydrothermal quartz samples from drill-hole cuttings and outcrops of small plutons near Mount Hood. Homogenization temperature data for the predominantly liquid-rich fluid inclusions are plotted for $2^{\circ} \mathrm{C}$ intervals. The only vapor-rich fluid inclusions for which homogenization temperatures were obtained are the three highest values for specimen 79IC-2040. 
layer clay minerals, generally have been found to occur at temperatures consistent with zeolite-facies metamorphism in active geothermal areas (Aumento and Liguori, 1986; Hulen and Nielson, 1986). Many minerals listed here occur in association with early greenschist to subgreenschist hydrothermal minerals and probably formed as intrusive rocks cooled into the temperature range of zeolite-facies metamorphism. Hydrothermal minerals associated with late Tertiary zeolite-facies metamorphism are fairly widespread in the Mount Hood area, rather than being confined to the greenschist to subgreenschist metamorphic halos that surround the late Tertiary intrusions.

\section{QUATERNARY METAMORPHISM}

Mount Hood, an active volcano, formed over about the past 700,000 years (Priest, 1982). The volcano experienced its last significant activity about 200 to 300 years ago during the Old Maid eruptive period (Crandell, 1980). Quaternary lava flows and volcaniclastic units from outcrops and drill-hole samples surrounding Mount Hood contain only minor evidence for very low temperature Quaternary metamorphism. Quaternary lava flows penetrated by one drill hole on the south side of Mount Hood (table 1, No. 11) have traces of low-temperature hydrothermal minerals (chalcedony, calcite, halloysite, gypsum, and hematite) and gibbsite, which probably formed from weathering. Active fumaroles with temperatures as high as $91{ }^{\circ} \mathrm{C}$ lie on the

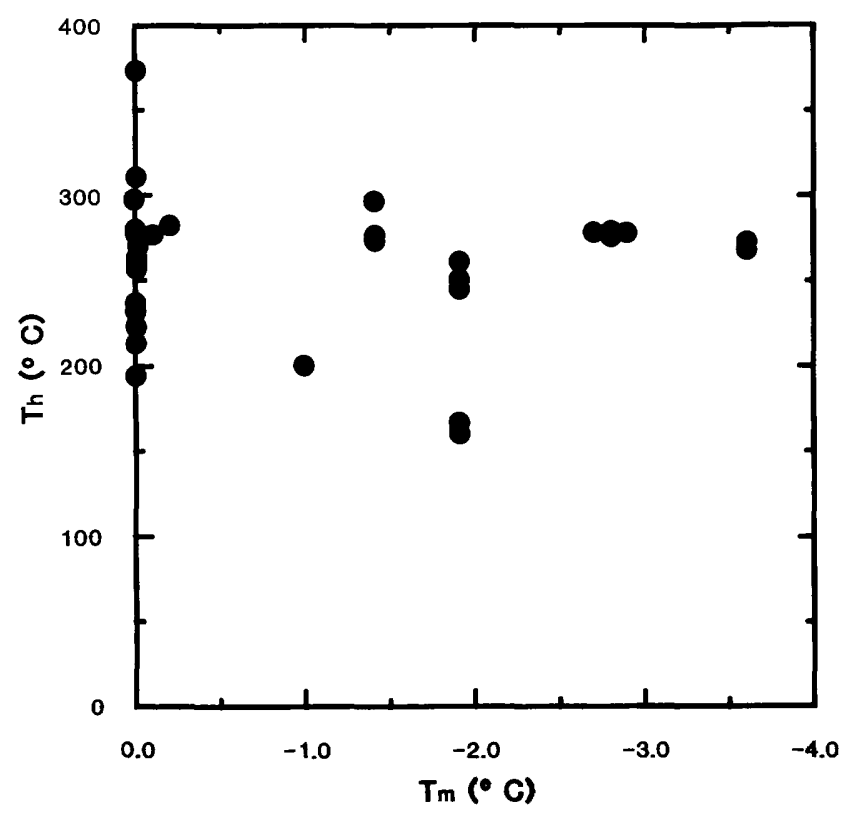

Figure 29. A plot of homogenization temperatures $\left(\mathrm{T}_{h}\right)$ versus melting-point temperatures $\left(\mathrm{T}_{\mathbf{m}}\right)$ for fluid inclusions in hydrothermal quartz crystals from Tertiary rock outcrop samples near Mount Hood. south side of the volcano within a few hundred meters of the summit (Nehring and others, 1981). An aerial infrared survey (Friedman and others, 1982) mapped active fumarole fields at Mount Hood and estimated total heat discharge to be about 5 to 12 megawatts. Friedman and others (1982) also concluded that the heat source is deep seated. White (1980) indicated that a still-hot volcanic conduit beneath Crater Rock could be the heat source for present-day, near-summit geothermal activity at Mount Hood. Other thermal features at Mount Hood include Swim Warm Springs, at the southern base of the mountain, and elevated temperatures (as high as $113^{\circ} \mathrm{C}$ at the bottom of the Old Maid Flat No. 7A drill hole) (Holdaway and Bussey, 1982) in some geothermal test drill holes.

Intense acid-sulfate leaching by present-day fumarolic activity readily alters volcanic rocks to a "sticky, blue or gray clay" (Cameron, 1988), usually consisting of kaolinite. Other secondary minerals from the fumarole area identified in our study include silica minerals (opal, $\beta$-cristobalite, and chalcedony), native sulfur, sulfate minerals (gypsum, alunite, natroalunite, jarosite, and natrojarosite), pyrite, iron oxides (amorphous iron oxide and hematite), and goethite. Many of these fumarolic mineral assemblages have been observed in glacial erratics on the upper slopes of Mount Hood, as well as in drill cuttings from several geothermal test drill holes located on the lower slopes and near the base of the mountain. Drill-cuttings samples from most of the studied drill holes contain volcaniclastic chips that are subrounded to rounded, are composed of a mixture of chips from different volcanic rock units, and contain one or more of the fumarolic minerals listed above. Undoubtedly, such hydrothermal alteration minerals were transported from the present fumarole field, or similar past sites of fumarolic activity, near the summit of Mount Hood. The transport mechanisms probably were quite variable and may have included streamflow, mudflows, lahars, avalanches, debris flows, or pyroclastic flows. Some recent Mount Hood lahar and debris-flow deposits have been studied by Gallino and Pierson (1984) and Cameron and Pringle (1986, 1987). Detailed mineralogical studies of the deposits were not reported; however, Frank (1983) completed a study of the hydrothermal mineralogy of similar deposits at Mount Baker, Washington. He concluded that a hydrothermal mineral suite, similar to the fumarolic minerals reported here for Mount Hood, occurs in five large mudflow deposits that originated near the summit fumarolic area of Mount Baker. Higher temperature minerals such as illite or mixed-layer illite-smectite are also associated with the fumarolic minerals both at Mount Baker (Frank, 1983) and at Mount Hood (this study).

Wollenberg and others (1979) completed a geochemical study of water from Swim Warm Springs, which are the only thermal springs in the vicinity of Mount Hood. They concluded that the warm springs (temperatures measured at several orifices are between $19^{\circ}$ and $26.5^{\circ} \mathrm{C}$ ) have been 
considerably diluted by cold, near-surface runoff. Several chemical geothermometers suggest that the temperature of unmixed water at depth may range from $104^{\circ}$ to $170^{\circ} \mathrm{C}$, although temperatures above $200^{\circ} \mathrm{C}$ may also be possible (Wollenberg and others, 1979). According to Wollenberg and others' (1979) model, water from melted snow and glacial ice is heated near the summit by contact with the volcanic conduit or "neck" of the volcano. The heated water percolates down slope through highly permeable lava flows and volcaniclastic debris units in which the thermal water is continuously mixed with cold meteoric water. When the water reaches Swim Warm Springs at the base of the mountain, the dilution factor is quite high and temperatures are low.

Holdaway and Bussey (1982) indicated that the only hydrothermal alteration in the Old Maid Flat 7A drill hole, attributable to present-day conditons, occurs at subzeolitealteration temperatures. They list stilbite, heulandite(?), smectite, chlorite, calcite, anhydrite, and hematite as alteration minerals consistent with measured temperatures up to $113^{\circ} \mathrm{C}$ (bottom of drill hole $7 \mathrm{~A}$ ). The McGee Creek drill hole (table 1, No. 3), on the lower northwest flank of Mount Hood, has a bottom-hole temperature of $60^{\circ} \mathrm{C}$. The drill hole apparently penetrated a mantle of Quaternary volcaniclastic debris (Wise, 1969) and late Tertiary lava flows and volcaniclastic debris units (J.H. Robison, L.S. Forcella, and M.W. Gannett, written commun., 1981). Hydrothermal alteration, consisting predominantly of heulandite, calcite, smectite, and hematite, occurs throughout most of this $610-\mathrm{m}$-deep drill hole below $47 \mathrm{~m}$ depth. Temperature measurements near the bottom of the Pucci Chairlift and Old Maid Flat 1 drill holes ( table 1, Nos. 13 and 5) are $65.5^{\circ} \mathrm{C}$ and $82^{\circ} \mathrm{C}$, respectively. Most hydrothermal mineralization in these drill holes appears to be associated with lava flows and volcaniclastic deposits that are interpreted as being late Tertiary in age.

\section{CONCLUSIONS}

Hydrothermal minerals identified from outcrop and drill-hole samples in the Mount Hood area were probably formed in the late Tertiary and are mostly associated with alteration halos surrounding several cooling intrusions. However, hydrothermal alteration, consistent with zeolitefacies temperatures, appears to have been of somewhat more regional extent during this period. Some low-temperature zeolite minerals (chabazite, scolecite, heulandite, stilbite, and epistilbite) (Kristmannsdóttir and Tómasson, 1978) and smectite are present in drill holes that penetrate Neogene volcanic units and in outcrops of Neogene age. Except for slumped fumarolic minerals, hydrothermal minerals in Quaternary lava flows and volcaniclastic debris units of Mount Hood are very sparse. Present temperatures in the majority of drill holes are below $\sim 23^{\circ} \mathrm{C}$, a tempera- ture which probably is too low even for formation of lowtemperature hydrothermal minerals listed above. Only in drill holes 3, 5, and 13 (table 1) are the bottom-hole temperatures $\left(60^{\circ}\right.$ to $\left.82^{\circ} \mathrm{C}\right)$ possibly warm enough for the formation of some of these low-temperature hydrothermal minerals; however, even in these drill holes hydrothermal minerals are likely to have formed in the late Tertiary.

On the basis of available data from geothermal exploration in the Mount Hood area, evidence for an exploitable (by current technology) geothermal system does not appear to be very great. Late Tertiary geothermal systems near Mount Hood apparently were of very limited extent and probably cooled markedly within a short distance from the heat source; conversely, late Tertiary lower temperature hydrothermal mineralization appears to have been widespread. The present-day situation may be similar in that the heat source for thermal activity in the Mount Hood area is not believed to be very extensive.

\section{REFERENCES CITED}

Aumento, Fabrizio, and Liguori, P.E., 1986, Conceptual reservoir models through geoscientific investigations: Geothermics, v. 15 , no. $5 / 6$, p. $799-806$.

Babcock, J.W., and Wilcox, R.E., 1977, Results of petrographic examination of samples, in Frank, David., Meier, M.F., and Swanson, D.A., Assessment of increased thermal activity at Mount Baker, Washington, March 1975-March 1976: U.S. Geological Survey Professional Paper 1022-A, p. A25-A26.

Baedecker, P.A., ed., 1987, Methods for geochemical analysis: U.S. Geological Survey Bulletin 1770, 156 p.

Bargar, K.E., 1980a, Lithologic log of drill cuttings for DOGAMI heat flow hole CR-SB, Mount Hood, Oregon: U.S. Geological Survey Open-File Report 80-521, 9 p.

$-1980 \mathrm{~b}$, Lithologic log of drill cuttings for Northwest Geothermal Corporation drill hole at Lost Creek near Mount Hood, Oregon: U.S. Geological Survey Open-File Report 80-1166, $11 \mathrm{p}$.

Bargar, K.E., and Beeson, M.H., 1985, Hydrothermal alteration in research drill hole Y-3, Lower Geyser Basin, Yellowstone National Park, Wyoming: U.S. Geological Survey Professional Paper 1054-C, 23 p.

Bargar, K.E., Fournier, R.O., and Theodore, T.G., 1985, Particles in fluid inclusions from Yellowstone National Park-Bacteria?: Geology, v. 13, p. 483-486.

Baross, J.A., and Deming, J.W., 1983, Growth of 'black smoker' bacteria at temperatures of at least $250^{\circ} \mathrm{C}$ : Nature, v. 303, p. 423-426.

Barrer, R.M., and Sammon, D.C., 1955, Exchange equilibria in crystals of chabazite: Chemical Society Journal, p. 28382849.

Beaufort, D., Westercamp, D., Legendre, O., and Meunier, A., 1990, The fossil hydrothermal system of Saint Martin, Lesser Antilles: geology and lateral distribution of alterations: Journal of Volcanology and Geothermal Research, v. 40, p. 219-243.

Beeson, M.H., Fecht, K.R., Reidel, S.P., and Tolan, T.L., 1985, Regional correlations within the Frenchman Springs Mem- 
ber of the Columbia River Basalt Group: New insights into the middle Miocene tectonics of northwestern Oregon: Oregon Geology, v. 47, no. 8, p. 87-96.

Beeson, M.H., Keith, T.E.C., and Bargar, K.E., 1980, Secondary mineralization in the Mt. Hood area, Oregon: Geological Society of America Abstracts with Programs, v. 12, no. 3, p. 96.

Beeson, M.H., and Moran, M.R., 1979, Stratigraphy and structure of the Columbia River Basalt Group in the Cascade Range, in Hull, D.A., investigator, and Riccio, J.F., ed., Geothermal resource assessment of Mount Hood: Oregon Department of Geology and Mineral Industries Open-File Report O-79-8, p. 5-77.

Beeson, M.H., Moran, M.R., Anderson, J.L., and Vogt, B.F., 1982, The relationship of the Columbia River Basalt Group to the geothermal potential of the Mount Hood area, Oregon, in Priest, G.R., and Vogt, B.F., eds., Geology and geothermal resources of the Mount Hood Area, Oregon: Oregon Department of Geology and Mineral Industries Special $\mathrm{Pa}-$ per 14, p. 43-46.

Bikerman, Michael, 1970, K-Ar ages of Laurel Hill pluton and dike, Oregon: Ore Bin, v. 32, no. 11, p. 211-215.

Bird, D.K., Schiffman, Peter, Elders, W.A., Williams, A.E., and McDowell, S.D., 1984, Calc-silicate mineralization in active geothermal systems: Economic Geology, v. 79, p. 671-695.

Blackwell, D.D., Black, G.L., and Priest, G.R., 1981a, Geothermal gradient data (1978): Oregon Department of Geology and Mineral Industries Open-File Report O-81-3A, 63 p.

1981b, Geothermal gradient data (1979): Oregon Department of Geology and Mineral Industries Open-File Report O-81-3B, 98 p.

1981c, Geothermal gradient data (1980): Oregon Department of Geology and Mineral Industries Open-File Report O-81-3C, 374 p.

Blackwell, D.D., and Steele, J.L., 1979, Heat flow modeling of the Mount Hood Volcano, Oregon, in Hull, D.A., investigator, and Riccio, J.F., ed., Geothermal resource assessment of Mount Hood: Oregon Department of Geology and Mineral Industries Open-File Report O-79-8, p. 190-264.

Bodnar, R.J., Reynolds, T.J., and Kuehn, C.A., 1985, Fluid-inclusion systematics in epithermal systems, in Berger, B.R., and Bethke, P.M., eds., Geology and geochemistry of epithermal systems: Society of Economic Geologists Reviews in Economic Geology, v. 2, p. 73-97.

Bodnar, R.J., and Sterner, S.M., 1984, Synthetic fluid inclusions in natural quartz I; compositional types synthesized and applications to experimental geochemistry: Geochimica et Cosmochimica Acta, v. 48 , p. $2659-2668$.

Boles, J.R., and Coombs, D.S., 1977, Zeolite facies alteration of sandstones in the Southland Syncline, New Zealand: American Journal of Science, v. 277, p. 982-1012.

Brock, T.D., 1985, Life at high temperatures: Science, v. 230, p. 132-138.

Brophy, G.P., Scott, E.C., and Snellgrove, R.A., 1962, Sulfate studies II; solid solution between alunite and jarosite: American Mineralogist, v. 47, p. 112-126.

Browne, P.R.L., and Ellis, A.J., 1970, The Ohaki-Broadlands hydrothermal area, New Zealand; mineralogy and related geochemistry: American Journal of Science, v. 269, p. 97-131.

Callaghan, Eugene, and Buddington, A.F., 1938, Metalliferous mineral deposits of the Cascade Range in Oregon: U.S. Geological Survey Bulletin 893, p. 141.
Cameron, K.A., 1988, Fumarole fields and thermal features at Mount Hood, Oregon: Northwest Science, v. 62, no. 2, p. 82.

Cameron, K.A., and Pringle, P.T., 1986, Post-glacial lahars of the Sandy River Basin, Mount Hood, Oregon: Northwest Science, v. 60 , no. 4 , p. $225-237$.

1987, A detailed chronology of the most recent eruptive period at Mount Hood, Oregon: Geological Society of America Bulletin, v. 99, p. 845-851.

Cerny', P., Rinaldi, Romano, and Surdam, R.D., 1977, Wellsite and its status in the phillipsite-harmotome group: Neues Jahrbuch fur Mineralogie Abhandlungen, v. 128, p. 312-330.

Coombs, D.S., 1955, X-ray observations on wairakite and noncubic analcime: Mineralogical Magazine, v. 30, p. 699-708.

Couch, Richard, and Gemperle, Michael, 1979, Gravity measurements in the area of Mount Hood, in Hall, D.A., investigator, and Riccio, J.F., ed., Geothermal resource assessment of Mount Hood: Oregon Department of Geology and Mineral Industries Open-File Report O-79-8, p. 137-189.

Covert, W.F., and Meyer, H.J., 1979, Geothermal observation wells, Mt. Hood, Oregon: U.S. Department of Energy Contract DE-AC08-78ET-28417, Report 1980-640-258/2420, U.S. Government Printing Office, Washington, D.C., 28 p.

Crandell, D.R., 1971, Postglacial lahars from Mount Rainier Volcano, Washington: U.S. Geological Survey Professional Paper $677,75 \mathrm{p}$.

-1980, Recent eruptive history of Mount Hood, Oregon and potential hazards from future eruptions: U.S. Geological Survey Bulletin 1492, $81 \mathrm{p}$.

Deer, W.A., Howie, R.A., and Zussman, J., 1966, An introduction to the rock-forming minerals: London, Longman Group Limited, 528 p.

Farooqui, S.M., Beaulieu, J.D., Bunker, R.C., Stensland, D.E., and Thoms, R.E., 1981, Dalles Group, Neogene formations overlying the Columbia River Basalt Group in north-central Oregon: Oregon Geology, v. 43, p. 131-140.

Flanagan, Guy, and Williams, D.L., 1982, A magnetic investigation of Mount Hood, Oregon: Journal of Geophysical Research, v. 87, no. B4, p. 2804-2814.

Frank, David, 1983, Origin, distribution, and rapid removal of hydrothermally formed clay at Mount Baker, Washington: U.S. Geological Survey Professional Paper 1022-E, 31 p.

Frey, Martin, and Kisch, H.J., 1987, Scope of subject, in Frey, Martin, ed., Low temperature metamorphism: New York, Chapman and Hall, p. 1-8.

Friedman, J.D., Williams, D.L., and Frank, David, 1982, Structural and heat flow implications of infrared anomalies at Mt. Hood, Oregon, 1972-1977: Journal of Geophysical Research, v. 87, no. B4, p. 2793-2803.

Galli, Ermanno, and Passaglia, Elio, 1973, Ștellerite from Villanova Monteleone, Sardinia: Lithos, v. 6, p. 83-90.

Galli, Ermanno, and Rinaldi, Romano, 1974, The crystal chemistry of epistilbites: American Mineralogist, v. 59, p. 10551061.

Gallino, G.L., and Pierson, T.C., 1984, The 1980 Polallie Creek debris flow and subsequent dam-break flood, East Fork Hood River Basin, Oregon: U.S. Geological Survey OpenFile Report 84-578, 44 p.

Gannett, M.W., 1982, A geochemical study of the Rhododendron and Dalles Formations in the area of Mount Hood, Oregon: Portland, Oregon, Portland State University M.S. thesis, 64 p. 
Gannett, M.W., and Bargar, K.E., 1981, Volcanic stratigraphy and secondary mineralization of USGS Pucci geothermal test well, Mount Hood, Oregon: U.S. Geological Survey Open-File Report 81-1330, 26 p.

Godwin, L.H., Haigler, L.B., Rioux, R.L., White, D.E., Muffler, L.J.P., and Wayland, R.G., 1971, Classification of public lands valuable for geothermal steam and associated geothermal resources: U.S. Geological Survey Circular 647, 18 p.

Goldstein, N.E., Mozley, E.C., and Wilt, M.J., 1982, Interpretation of shallow electrical features from electromagnetic and magnetotelluric surveys at Mount Hood, Oregon: Journal of Geophysical Research, v. 87, p. 2815-2828.

Gottardi, Glauco, and Galli, Ermanno, 1985, Natural zeolites: Berlin, Springer-Verlag, 409 p.

Grim, R.E., 1968, Clay mineralogy: San Francisco, McGraw-Hill Book Company, 596 p.

Harris, S.L., 1976, Fire and ice; the Cascade volcanoes: Seattle, Mountaineers Pacific Search Press, 320 p.

1988, Fire mountains of the West, the Cascade and Mono Lake volcanoes: Missoula, Mountain Press Publishing Co., 379p.

Holdaway, M.J., and Bussey, Steven, 1982, Mineralogy of the Old Maid Flat geothermal exploratory hole no. 7A, Mount Hood, Oregon, in Priest, G.R., and Vogt, B.F., eds., Geology and geothermal resources of the Mount Hood area, Oregon: Oregon Department of Geology and Mineral Industries Special Paper 14, p. 57-76.

Holland, H.D., and Malinin, S.D., 1979, The solubility and occurrence of non-ore minerals, in Barnes, H.L., ed., Geochemistry of hydrothermal ore deposits: New York, John Wiley \& Sons, p. 461-508.

Hook, J.W., 1982, History of geothermal exploration in the Mount Hood area, Oregon, in Priest, G.R., and Vogt, B.F., eds., Geology and geothermal resources of the Mount Hood area, Oregon: Oregon Department of Geology and Mineral Industries Special Paper 14, p. 3-5.

Horton, D.G., 1985, Mixed-layer illite/smectite as a paleotemperature indicator in the Amethyst vein system, Creede district, Colorado, USA: Contributions to Mineralogy and Petrology, v. 91, p. 171-191.

Hower, John, 1981, X-ray diffraction identification of mixed-layer clay minerals: Mineralogical Association of Canada Short Course, p. 39-59.

Hulen, J.B., and Nielson, D.L., 1986, Hydrothermal alteration in the Baca geothermal system, Redondo Dome, Valles Caldera, New Mexico: Journal of Geophysical Research, v. 91, no. B2, p. 1867-1886.

Hull, D.A., Blackwell, D.D., and Black, G.L., 1978, Geothermal gradient data: Oregon Department of Geology and Mineral Industries Open-File Report O-78-4, 187 p.

Keith, T.E.C., Bargar, K.E., and Beeson, M.H., 1982, Geochemical map of the Mount Hood Wilderness, Clackamas and Hood River Counties, Oregon: U.S. Geological Survey Miscellaneous Field Studies Map MF-1379C, scale 1:62,500.

Keith, T.E.C., Beeson, M.H., and Bargar, K.E., 1982, Geologic map of the Mount Hood Wilderness, Clackamas and Hood River Counties, Oregon: U.S. Geological Survey Miscellaneous Field Studies Map MF-1379A, scale 1:62,500.

Keith, T.E.C., Beeson, M.H., Bargar, K.E., and Marsh, S.P., 1980, Geochemical data for rock, stream sediment, and panned con- centrate samples, Mount Hood Wilderness Area, Oregon: U.S. Geological Survey Open-File Report 80-839, 41 p.

Keith, T.E.C., Casadevall, T.J., and Johnston, D.A., 1981, Fumarole encrustations; occurrence, mineralogy, and chemistry: U.S. Geological Survey Professional Paper 1250, p. 239250.

Keith, T.E.C., and Causey, J.D., 1982, Mineral and geothermal resource potential of the Mount Hood Wilderness, Clackamas and Hood River Counties, Oregon; summary report: U.S. Geological Survey Miscellaneous Field Studies Map MF-1379E, scale 1:62,500, 8 p. text.

1984, Mount Hood Wilderness and adjacent areas, Oregon: U.S. Geological Survey Professional Paper 1300, p. 885-888.

Keith, T.E.C., Donnelly-Nolan, J.M., Markman, J.L., and Beeson, M.H., 1985, K-Ar ages of rocks in the Mount Hood area, Oregon: Isochron/West, no. 42, p. 12-16.

Krieger, Philip, 1930, Notes on an X-ray diffraction study of the series calcite-rhodochrosite: American Mineralogist, v. 15, p. 23-29.

Kristmannsdóttir, Hrefna, 1982, Alteration in the IRDP drill hole compared with other drill holes in Iceland: Journal of Geophysical Research, v. 87, no. B8, p. 6525-6531.

Kristmannsdóttir, Hrefna, and Tómasson, Jens, 1978, Zeolite zones in geothermal areas of Iceland, in Sand, L.B., and Mumpton, F.A., Natural zeolites; occurrence, properties, use: New York, Pergamon Press, p. 277-284.

Liou, J.G., Maruyama, Shigenori, and Cho, Moonsup, 1987, Very low-grade metamorphism of volcanic and volcaniclastic rocks-mineral assemblages and mineral facies, in Frey, Martin, ed., Low temperature metamorphism: New York, Chapman and Hall, p. 59-113.

Livingstone, A., 1989, Low-temperature, hydrothermal garnet associated with zeolites, from basalt lavas near Beith, Ayrshire: Mineralogical Magazine, v. 53, p. 125-129.

Lo, H.J., 1981, Hydrothermal synthesis of epistilbite from materials with the compositions of $\mathrm{CaO} \cdot \mathrm{Al}_{2} \mathrm{O}_{3} \cdot 2-10 \mathrm{SiO}_{2}$ : Proceedings of the Geological Society of China, no. 24, p. 9-20.

Lucchetti, G., Massa, B., and Penco, A.M., 1982, Strontian heulandite from Campegli (Eastern Ligurian Ophiolites, Italy): Neues Jahrbuch fur Mineralogie Monatshefte, h. 12, p. 541550 .

Mankinen, E.A., and Dalrymple, G.B., 1979, Revised geomagnetic polarity time scale for the interval 0-5 m.y. B.P.: Journal of Geophysical Research, v. 84, no. B2, p. 615-626.

Mason, B., and Sand, L.B., 1960, Clinoptilolite from Patagonia; the relationship between clinoptilolite and heulandite: American Mineralogist, v. 45, p. 341-350.

McCulloh, T.H., Frizzell, V.A., Jr., Stewart, R.J., and Barnes, Ivan, 1981, Precipitation of laumontite with quartz, thenardite, and gypsum at Sespe Hot Springs, western Transverse Ranges, California: Clays and Clay Minerals, v. 29, no. 5, p. 353-364.

McKee, E.H., Swanson, D.A., and Wright, T.L., 1977, Duration and volume of Columbia River Basalt volcanism, Washington, Oregon, and Idaho: Geological Society of America Abstracts with Programs, v.9, p. 463-464.

Miller, B.E., and Ghent, E.D., 1973, Laumontite and barianstrontian heulandite from the Blairmore group (Cretaceous), Alberta: Canadian Mineralogist, v. 12, p. 188-192. 
Mondale, K.D., Mumpton, F.A., and Aplan, F.F., 1978, Beneficiation of natural zeolites from Bowie, Arizona; a preliminary report, in Sand, L.B., and Mumpton, F.A., eds., Natural zeolites; occurrence, properties, use: New York, Pergamon Press, p. 527-537.

Mumpton, F.A., 1960, Clinoptilolite redefined: American Mineralogist, v. 45 , p. 351-369.

Naboko, S.I., 1959, Volcanic exhalations and products of their reactions as exemplified by Kamchatka-Kuriles volcanoes: Bulletin of Volcanology, v. 20, p. 121-136.

Nehring, N.L., Wollenberg, H.A., and Johnston, D.A., 1981, Gas analyses of fumaroles from Mt. Hood, Oregon: U.S. Geological Survey Open-File Report 81-236, 9 p.

Onuki, Hitoshi, Shiba, Masatoshi, and Tazaki, Akira, 1988, Notes on petrology and rock-forming mineralogy (19) vein-forming Ca-zeolites from the Miocene metabasites at Okiura, Kuroishi City, Aomori Prefecture: Journal of Mineralogy, Petrology, and Economic Geology, v. 83, p. 311-317.

Oregon Department of Geology and Mineral Industries, 1978, Geophysical logs, Old Maid Flat No. 1, Clackamas County, Oregon: Oregon Department of Geology and Mineral Industries Open-File Report O-78-6, 6 logs.

Park, C.F., Jr., and MacDiarmid, R.A., 1964, Ore deposits: San Francisco, W.H. Freeman \& Company, 475 p.

Passaglia, Elio, 1970, The crystal chemistry of chabazites: American Mineralogist, v. 55, p. 1278-1301.

Passaglia, Elio, Galli, Ermanno, Leoni, Leonardo, and Rossi, Giuseppe, 1978, The crystal chemistry of stilbites and stellerites: Bulletin de Mineralogie, v. 101, p. 368-375.

Passaglia, Elio, and Pongiluppi, Daria, 1974, Sodian stellerite from Capo Pula, Sardegna: Lithos, v. 7, p. 69-73.

Peck, D.L., Griggs, A.B., Schlicker, H.G., Wells, F.G., and Dole, H.M., 1964, Geology of the central and northern parts of the Western Cascade Range in Oregon: U.S. Geological Survey Professional Paper 449, 56 p.

Phillips, W.R., and Griffen, D.T., 1981, Optical mineralogy; the nonopaque minerals: San Francisco, W.H., Freeman and Company, $677 \mathrm{p}$.

Priest, G.R., 1982, Overview of the geology and geothermal resources of the Mount Hood area, Oregon, in Priest, G.R., and Vogt, B.F., eds., Geology and geothermal resources of the Mount Hood area, Oregon: Oregon Department of Geology and Minerai Industries, Special Paper 14, p. 6-15.

Priest, G.R., Beeson, M.H., Gannett, M.W., and Berri, D.A., 1982, Geology, geochemistry, and geothermal resources of the Old Maid Flat area, Oregon, in Priest, G.R., and Vogt, B.F., eds., Geology and geothermal resources of the Mount Hood area, Oregon: Oregon Department of Geology and Mineral Industries, Special Paper 14, p. 16-30.

Priest, G.R., and Vogt, B.F., eds., 1982, Geology and geothermal resources of the Mount Hood area, Oregon: Oregon Department of Geology and Mineral Industries Special Paper 14, 100 p.

Reynolds, R.C., 1980, Interstratified clay minerals, in Brindley, G.W., and Brown, G., eds., Crystal structures of clay minerals and their X-ray identification: London, Mineralogical Society Monograph no. 5, Chapter 4, p. 249-300.

Robert, Christian, 1988, Barian phillipsite and strontian chabazite from the Plateau des Coirons, Ardeche, France: Bulletin de Mineralogie, v. 111, p. 671-677.
Robison, J.H., Forcella, L.S., and Gannett, M.W., 1981, Data from geothermal test wells near Mount Hood, Oregon: U.S. Geological Survey Open-File Report 81-1002, 24 p.

Robison, J.H., Keith, T.E.C., Beeson, M.H., and Bargar, K.E., 1982, Map showing geothermal investigations in the vicinity of the Mount Hood Wilderness, Clackamas and Hood River Counties, Oregon: U.S. Geological Survey Miscellaneous Field Studies Map MF-1379-B, scale 1:62,500.

Roedder, E., 1962, Studies of fluid inclusions I; low temperature application of a dual-purpose freezing and heating stage: Economic Geology, v. 57, p. 1045-1061.

1984, Fluid inclusions, in Ribbe, P.H., ed., Reviews in Mineralogy, v. 12: Washington, D.C., Mineralogical Society of America, $644 \mathrm{p}$.

Schiffman, Peter, Bird, D.K., and Elders, W.A., 1985, Hydrothermal mineralogy of calcareous sandstones from the Colorado River delta in the Cerro Prieto geothermal system, Baja California, Mexico: Mineralogical Magazine, v. 49, p. 435-449.

Seki, Yotaro, 1972, Lower grade stability limit of epidote in the light of natural occurrences: Geological Society of Japan Journal , v. 78, p. 405-413.

Semmens, M.J., and Seyforth, M., 1978, The selectivity of clinoptilolite for certain heavy metals, in Sand, L.B., and Mumpton, F.A., eds., Natural zeolites; occurrence, properties, use: New York, Pergamon Press, p. 517-526.

Starkey, H.C., Blackmon, P.D., and Hauff, P.L., 1984, The routine mineralogical analysis of clay-bearing samples: U.S. Geological Survey Bulletin 1563, 32 p.

Steele, J.L., Blackwell, D.D., and Robison, J.H., 1982, Heat flow in the vicinity of the Mount Hood Volcano, Oregon, in Priest, G.R., and Vogt, B.F., eds., Geology and geothermal resources of the Mount Hood area, Oregon: Oregon Department of Geology and Mineral Industries Special Paper 14, p. 31-42.

Taylor, H.F.W., ed., 1964, The chemistry of cements: New York, Academic Press, v. 1, 460 p.

Tomita, Katsutoshi, Yamashita, Hiroyuki, and Oba, Noboru, 1969, Artificial crystallization of volcanic glass to sodium and potassium form of chabazite at room pressure: Japanese Association of Mineralogists, Petrologists, and Economic Geologists Journal, v. 62, no. 2, p. 80-89.

Trent, J.D., Chastain, R.A., and Yayanos, A.A., 1984, Possible artifactual basis for apparent bacterial growth at $250^{\circ} \mathrm{C}$ : Nature, v. 307 , p. 737-740.

Trimble, D.E., 1963, Geology of Portland, Oregon, and adjacent areas: U.S. Geological Survey Bulletin 1119, 119 p.

Tsusue, Akio, 1967, Magnesian kutnahorite from Ryujima Mine, Japan: American Mineralogist, v. 52, p. 1751-1761.

White, C.M., 1979, Geology and geochemistry of Mt. Hood volcano, in Hull, D.A., investigator, and Riccio, J.F., ed., Geothermal resource assessment of Mount Hood: Oregon Department of Geology and Mineral Industries Open-File Report, 0-79-8, p. 78-136.

1980, Geology and geochemistry of Mt. Hood Volcano: Oregon Department of Geology and Mineral Industries Special Paper 8, $26 \mathrm{p}$.

White, D.E., Hutchinson, R.A., and Keith, T.E.C., 1988, The geology and remarkable thermal activity of Norris Geyser Basin, Yellowstone National Park, Wyoming: U.S. Geological Survey Professional Paper 1456, 84 p. 
Williams, D.L., Hull, D.A., Ackermann, H.D., and Beeson, M.H., 1982, The Mt. Hood region; volcanic history, structure, and geothermal energy potential: Journal of Geophysical Research, v. 87, p. 2767-2781.

Williams, D.L., and Keith, T.E.C., 1982, Aeromagnetic and bouguer gravity maps of Mount Hood wilderness, Clackamas and Hood River Counties, Oregon: U.S. Geological Survey Miscellaneous Field Studies Map MF 1379-D, 2 sheets, scale 1:62,500.

Wise, W.S., 1968, Geology of the Mount Hood volcano, in Dole, H.M., ed., Andesite Conference guidebook: Oregon Department of Geology and Mineral Industries Bulletin 62, p. 8198.
1969, Geology and petrology of the Mt. Hood area; a study of High Cascade volcanism: Geological Society of America Bulletin, v. 80, p. 969-1006.

Wise, W.S., and Euster, H.P., 1964, Celadonite; synthesis, thermal stability, and occurrence: American Mineralogist, v. 49, nos. 7 and 8, p. 1031-1083.

Wollenberg, H.A., Bowen, R.E., Bowman, H.R., and Strisower, Beverly, 1979, Geochemical studies of rocks, water, and gases at Mt. Hood, Oregon: Lawrence Berkeley Laboratory Report LB7-7092, 57 p.

Zeng, Yishan, and Liou, J.G., 1982, Experimental investigation of yugawaralite-wairakite equilibrium: American Mineralogist, v. 67, p. 937-943. 

APPENDIXES A AND B 


\title{
APPENDIX A. LITHOLOGIC DESCRIPTIONS AND DISTRIBUTION OF HYDROTHERMAL MINERALS IN SELECTED MOUNT HOOD GEOTHERMAL DRILL HOLES.
}

\begin{abstract}
[Mineralogical descriptions and mineral identifications are based on binocular microscope observations, X-ray diffraction analyses (XRD), and petrographic microscope studies. The distribution of hydrothermal minerals with depth in the drill holes is shown by short horizontal line segments in the appendix A figures. USGS, U.S. Geological Survey; NWNG, Northwest Natural Gas Company; DOGAMI, Oregon Department of Geology and Mineral Industries; CIPW norms, classification of igneous rocks based on the normative mineralogy; drill hole numbers refer to numbers used in table 1]
\end{abstract}

\section{Lithologic symbols used in appendix A figures}

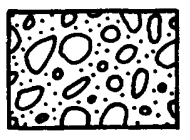

Volcaniclastic debris-may consist of alluvial, landslide, colluvi-

al, fluvial, glacial, mudflow, lahar, or pyroclastic deposits

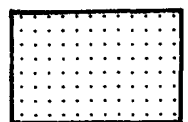

Andesite and basalt lava flows

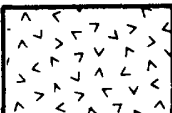

Quartz diorite to quartz monzonite intrusive rocks

\section{ELIOT BRANCH}

The USGS Eliot Branch drill hole was spudded in an unconsolidated Quaternary alluvial fan at the Eliot Branch of the Middle Fork of the Hood River. Drill cuttings from the 220-m-deep drill hole are composed predominantly of angular to subrounded clastic (mudflow) deposits mapped as unit Qhe (postglacial debris, in part) by Wise (1969); four porphyritic hypersthene andesite flows occur in the lower half of the drill hole (Robison and others, 1981).

\section{Depth (m) Description of drill cuttings}

0-125 Volcaniclastic debris. Largely mudflow deposits consisting of angular to subrounded grains of light- to dark-gray pyroxene or hornblende andesite; other primary minerals are plagioclase and magnetite. $\alpha$-cristobalite, formed by devitrification of volcanic glass, is present in most (XRD) analyses. Many samples contain white-bleached grains or orange- to red-stained grains (amorphous iron oxide) that consist mostly of hydrothermal minerals: opal, chalcedony, sulfate minerals (alunite, natroalunite, jarosite, natrojarosite, or gypsum), kaolinite, smectite, and pyrite.

125-127 Medium-gray, porphyritic, hypersthene andesite flow.

127-143 Volcaniclastic debris consisting mostly of fine hypersthene andesite grains; the interval contains a few bleached or orange-stained grains.

143-146 Medium-gray, porphyritic, hypersthene andesite flow.

146-149 Volcaniclastic debris. A mixture of varicolored fine andesite grains, a few bleached or orangestained grains, and plagioclase crystals.

149-159 Light-gray, porphyritic, hypersthene andesite flow.

159-199 Volcaniclastic debris. Subangular to subrounded, hypersthene andesite grains. A few grains are or- ange or yellow stained, but only plagioclase, $\alpha$ cristobalite, and orthopyroxene were identified by XRD.

199-201 Porphyritic, hypersthene andesite flow.

201-220 Clastic debris. Subangular to subrounded, varicolored, hypersthene andesite grains with some yellowish-stained grains; XRD analysis of one of the stained samples indicates that opal, tridymite, and $\alpha$-cristobalite are present.

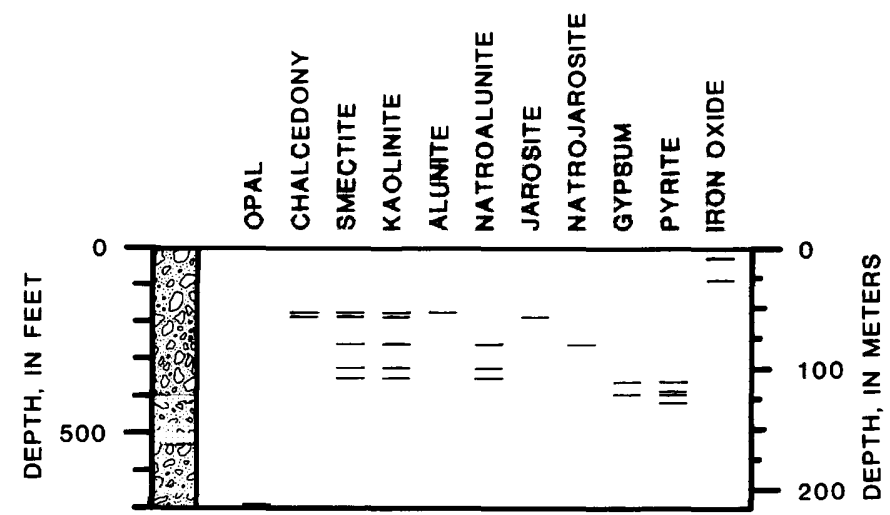

Stratigraphic representation of the Eliot Branch drill hole showing the distribution of hydrothermal minerals. 


\section{CLEAR BRANCH}

The 311-m-deep Clear Branch USGS drill hole was sited near the Clear Branch of the Middle Fork of the Hood River in unit Plv (lower Pliocene basalts and andesites) as mapped by Wise (1969); Keith and others (1982) remapped the unit as Tla (lower andesite flows (Miocene)). The Clear Branch drill cuttings mostly consist of volcaniclastic debris similar to the postglacial clastic debris units penetrated by the Eliot Branch drill hole. Interspersed with the clastic intervals are four hypersthene andesite flows (Robison and others, 1981).

Depth (m) Description of drill cuttings

0-79 Volcaniclastic debris. A mixture of angular to rounded, varicolored, hypersthene andesite grains; several grains are stained orange red. Hematite plagioclase, tridymite, $\alpha$-cristobalite, orthopyroxene, and magnetite were identified by XRD.

79-105 Medium-gray, hypersthene andesite flow.

105-173 Volcaniclastic debris consisting of angular to rounded grains of lithic-crystal tuff, orangish siliceous (B-cristobalite) cemented material, or hypersthene andesite; many andesite grains are bleached white or stained yellow orange. XRD analyses of the bleached or stained grains indicate that they consist of plagioclase, $\alpha$-cristobalite or tridymite, hypersthene or hornblende, hematite, smectite, natroalunite, and pyrite. The interval also has some gypsum needles (associated with pyrite), which may have formed after retrieval of the drill core; minor calcite may be due to contamination by drilling cement .

173-177 Black, hypersthene andesite flow. Plagioclase, orthopyroxene, magnetite, and $\alpha$-cristobalite were identified by XRD.

177-232 Volcaniclastic debris. A mixture of angular to rounded, hypersthene andesite grains; many grains are orange stained and consist of plagioclase, $\alpha$-cristobalite or tridymite, magnetite, smectite, natroalunite, mordenite, and pyrite. One sample also contains opal and calcite.

232-235 Brownish, hypersthene andesite flow. Plagioclase, $\alpha$-cristobalite, orthopyroxene, magnetite, and smectite were identified by XRD.
235-241 Volcaniclastic debris consisting of angular to rounded, hypersthene andesite grains; a few grains are orange stained.

241-246 Greenish-gray, hypersthene andesite flow. Minerals identified by XRD are plagioclase, orthopyroxene, magnetite, and $\alpha$-cristobalite.

246-311 Volcaniclastic debris. A mixture of varicolored, angular to rounded, hypersthene andesite grains; yellow-brown, lithic-crystal tuff with fibrous mordenite alteration; and many grains of buffred- or green-colored silica (B-cristobalite) or silica vesicle fillings in andesite. Some grains have orange hematite staining. One sample has minor calcite, and XRD reflections for smectite occur in two analyzed samples.

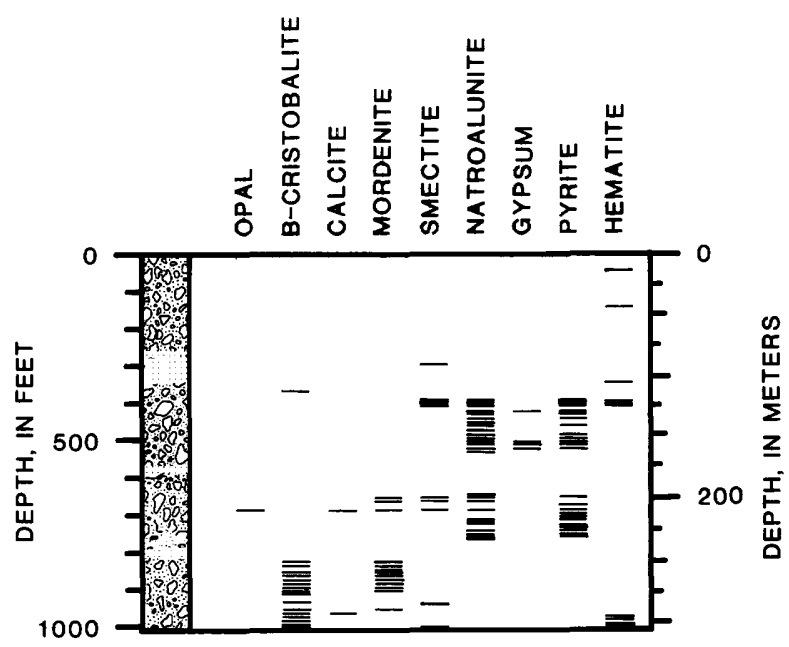

Stratigraphic representation of the Clear Branch drill hole showing the distribution of hydrothermal minerals.

\section{MCGEE CREEK}

A 610-m-deep USGS drill hole at McGee Creek was begun in unit Qhc (postglacial debris, in part) as mapped by Wise (1969). The upper few tens of meters may consist of this Quaternary volcaniclastic unit; however, pervasive hydrothermal alteration throughout the remainder of the drill hole suggests that the rocks penetrated during drilling may consist of older Tertiary andesite lava flows, clastic debris, and mudflows (Robison and others, written commun., 1981; 1982).

\section{Depth $(m) \quad$ Description of drill cuttings}

0-47 Volcaniclastic debris. A mixture of angular to rounded, greenish, brownish, or light- to darkgray, pyroxene andesite; black basalt or basaltic andesite; and orange, iron-oxide-stained grains. Most grains consist of plagioclase, $\alpha$-cristobalite, orthopyroxene, and magnetite. Some grains have vapor-phase, tridymite crystals. Hydrothermal alteration minerals identified by XRD are smectite, chalcedony, hematite, calcite, and siderite; one sample has a single pyrite crystal.

47-64 Mostly light-gray, pyroxene andesite grains with some reddish, iron oxide staining. Plagioclase, $\alpha$-cristobalite, clinopyroxene, hornblende, and magnetite were identified by XRD. Some grains are rounded, and a few are slightly vesicular with either buff smectite or tiny, colorless, heulandite crystals lining cavities. Hydrothermal 
minerals identified by XRD are hematite, heulandite, smectite, and calcite.

64-76 Reddish, andesitic, lithic tuff is composed of plagioclase, $\alpha$-cristobalite, tridymite, clinopyroxene, hornblende, and magnetite. Alteration minerals, mostly from a few bleached or orangestained grains, include hematite, smectite, calcite, heulandite, alunite, dolomite, and manganoan calcite. A few grains, containing a black mineral which was identified by XRD as spinel with associated smectite, hematite, and corundum(?), might be xenolith fragments.

76-128 Reddish-gray, slightly vesicular, porphyritic, pyroxene andesite flow with plagioclase, $\alpha$-cristobalite, hornblende, and pyroxene plus abundant disseminated magnetite crystals (partly altered to hematite). A few grains have yellow-orange or bleached alteration material; other grains contain veins or cavity fillings of colorless to white colloform masses of rhombic carbonate minerals (dolomite, manganoan calcite, rhodochrosite, or calcite). Colorless, euhedral, heulandite crystals line cavities and veins. Most samples contain some smectite identified by XRD.

128-140 Light-gray to greenish-gray, pyroxene andesite flow with minor hematite, smectite, calcite, and heulandite hydrothermal mineralization.

140-155 Volcaniclastic debris consisting of a mixture of angular to rounded, light- to medium-gray, andesite grains. A few reddish grains appear to be sedimentary mudstone or sandstone. Hydrothermal alteration minerals are calcite, heulandite, hematite, and smectite.

155-274 Light- to medium-gray, hornblende and pyroxene andesite grains from several flows. Most grains are angular to subrounded, but several samples contain rounded or even well-rounded grains; the interval may also contain volcaniclastic debris units. Hydrothermal minerals include smectite, heulandite, calcite (in order of paragenesis), and chalcedony (in one sample). One grain has black spinel crystals and is probably from a xenolith. In tables 1 and 2, specimen MGCR600 , analysis 36 is a whole-rock chemical analysis of hornblende andesite from a depth of about $182.9 \mathrm{~m}$

274-311 Reddish, andesitic tuff altered to red clay. Alteration minerals are smectite, calcite, hematite, and heulandite.

311-341 Volcaniclastic debris. A mixture of hypersthene andesite grains composed of plagioclase, $\alpha$-cristobalite, orthopyroxene and magnetite. Hydrothermal minerals are smectite, calcite, heulandite, and chalcedony.

341-357 Brownish, pyroxene andesite flow. Hydrothermal alteration minerals are calcite, heulandite, smecite, hematite, and chalcedony.
357-375 Volcaniclastic debris consisting of a mixture of pyroxene andesite grains. Hydrothermal alteration minerals are hematite, smectite, calcite, heulandite, and chalcedony. At about $360 \mathrm{~m}$ depth, one grain contained spinel that is probably from a xenolith.

375-378 Dark greenish-gray, pyroxene andesite flow. Hydrothermal minerals are heulandite, calcite, and smectite.

378-398 Volcaniclastic debris(?). Fine-grained cuttings consist mostly of plagioclase crystals. Hydrothermal alteration minerals are calcite, heulandite, and smectite.

398-427 Reddish-gray, hornblende andesite flow composed of plagioclase and hornblende phenocrysts (to $1.5 \mathrm{~mm}$ ) in a matrix of tiny hornblende and magnetite crystals. Hydrothermal alteration minerals are calcite, heulandite, smectite, magnetite(?), hematite, and pyrite.

427-610 Volcaniclastic debris(?) consisting mostly of a mixture of varicolored, andesite grains. A few of the fine-grained samples appear to be composed primarily of a single color of andesite grains (thin flows?) mixed with sloughed(?) andesite grains from higher in the drill hole. Hydrothermal minerals are calcite, pyrite, chalcedony, heulandite, smectite, and hematite.

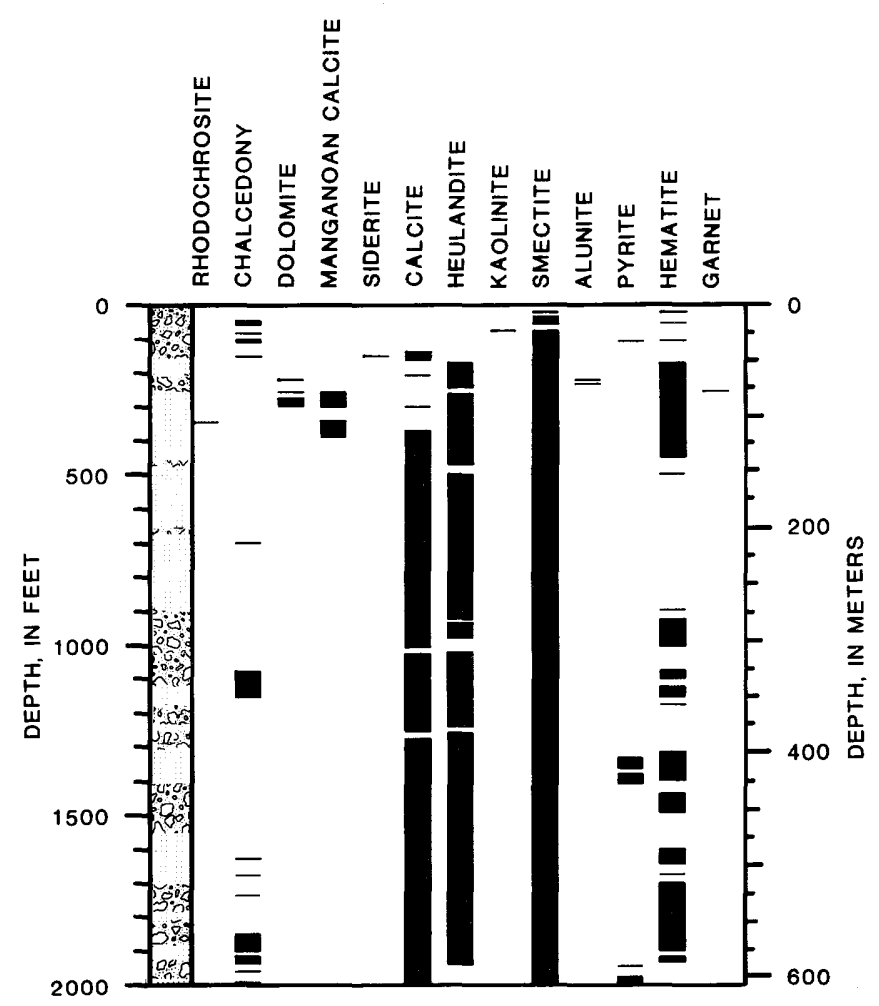

Stratigraphic representation of the McGee Creek drill hole showing the distribution of hydrothermal minerals. 


\section{LAST CHANCE MOUNTAIN}

The 152-m-deep Last Chance Mountain drill hole, completed by NWNG, was sited in unit Plv (lower Pliocene basalts and andesites) of Wise (1969), which Keith and others (1982) remapped as unit Tla (lower andesite flows (Miocene)). The upper $58 \mathrm{~m}$ of drill cuttings appears to consist of this Neogene, pyroxene andesite flow. Below $58 \mathrm{~m}$ depth, the drill cuttings are composed of volcaniclastic debris layers and andesitic lava flows correlated with the late Miocene Rhododendron Formation (Priest and others, 1982; Trimble, 1963).

\section{Depth (m) Description of drill cuttings}

0-58 Brownish-gray, hypersthene andesite flow composed of plagioclase, $\alpha$-cristobalite, hypersthene, and magnetite. Hydrothermal vein or fracture fillings consist of chalcedony, B-cristobalite, quartz, smectite, calcite, pyrite, amorphous iron oxide, and a zeolite mineral (stilbite?); one sample has a little gypsum associated with pyrite. Many samples contain caramel-colored grains of clay (sepiolite(?) + smectite) that may be contamination due to drilling. Between about 30 and $40 \mathrm{~m}$ depth, the drill cuttings contain a few grains of quartz diorite contsisting of plagioclase and quartz plus hydrothermal minerals: chlorite, actinolite(?), pyrite, and epidote.

58-85 Volcaniclastic debris. A mixture of angular to subrounded grains of light- to dark-gray, pyroxene andesite and varicolored, lithic tuff. Hydrothermal minerals are B-cristobalite, chalcedony, quartz, stilbite(?), calcite, smectite, chlorite, mixed-layer illite-smectite, hematite, pyrite, and gypsum. The cuttings contain some caramel-colored sepiolite (drilling contamination?).

85-88 Light-reddish-gray-green, lithic tuff. Alteration minerals are hematite, smectite, chlorite, and mixed-layer illite-smectite.

88-94 Dark-gray to black, amygdaloidal, andesite or basalt(?) flow with amygdule fillings of green clay (smectite and chlorite by XRD), and later calcite or chalcedony.

94-98 White to light-gray, bedded(?), lithic tuff. Hydrothermal minerals are pyrite, calcite, and green clay (sloughed from above ?).

98-113 Dark-gray to black, porphyritic, hypersthene andesite or basalt(?) flow; some smectite was identified by XRD in representative whole rock samples. Hydrothermal alteration minerals, calcite, pyrite, B-cristobalite, smectite, and mixedlayer illite-smectite, are mostly associated with a few bleached (erratic?) grains.

113-125 Volcaniclastic debris. A mixture of angular to rounded, dark gray to black, hypersthene andesite or basalt(?); black, vesicular basalt(?); and green- ish, bluish, or reddish tuffaceous grains. Alteration minerals are calcite, hematite, B-cristobalite, smectite, quartz, and chlorite.

125-128 Green, crystal to lithic tuff. Hydrothermal minerals are calcite, hematite, smectite, and euhedral to subhedral, quartz crystals ( $\sim \mathrm{mm}$ ) and crystal clusters.

128-134 Dark-brownish-gray to black, porphyritic, hypersthene andesite flow. Alteration minerals are smectite, calcite, and quartz.

134-137 Reddish, lithic-tuff breccia. Hydrothermal minerals include calcite, quartz, hematite, and smectite.

137-140 Volcaniclastic debris. A mixture of angular to subrounded grains of reddish, tuff breccia; bluishgreen and white lithic tuff; and varicolored, mostly altered, andesite grains. Alteration minerals are calcite, quartz, white colloform B-cristobalite, smectite, and caramel-colored sepiolite grains (drilling contamination?).

140-149 Dark-brownish-gray, porphyritic, hypersthene andesite flow with fractures filled by hydrothermal minerals: calcite, smectite, chalcedony, quartz, pyrite, and illite.

149-152 Volcaniclastic debris(?). A mixture of mostly finegrained drill cuttings (light-bluish-greenish tuff grains predominate in one sample). Hydrothermal minerals consist of abundant pyrite and some calcite, quartz, chlorite, smectite, and illite.

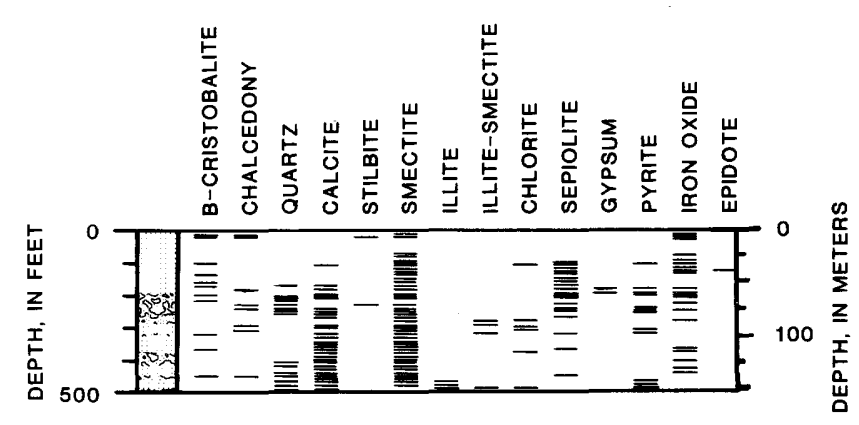

Stratigraphic representation of the Last Chance Mountain drill hole showing the distribution of hydrothermal minerals.

\section{OLD MAID FLAT (OMF-1)}

A detailed stratigraphic log of the Old Maid Flat 1 drill hole is given in Priest and Vogt (1982). The drill hole penetrated a Holocene mudflow deposit, lava flows and volcaniclastic debris deposits of the Rhododendron Formation, hornblende quartz microdiorite, and basalt flows from several units of the Columbia River Basalt Group. Major-element analyses, CIPW norms, modal analyses, and traceelement analyses of drill cuttings and core from this drill hole are given in Priest and Vogt (1982). Priest and others (1982) compared this drill hole with the nearby Old Maid Flat 7A drill hole. Geophysical logs for the Old Maid Flat 1 drill hole were published by the Oregon Department of Geology and Mineral Industries (1978). This report lists the secondary- alteration minerals identified in the Old Maid Flat 1 drill hole; however, a stratigraphic description of the drill cuttings is not reproduced. 


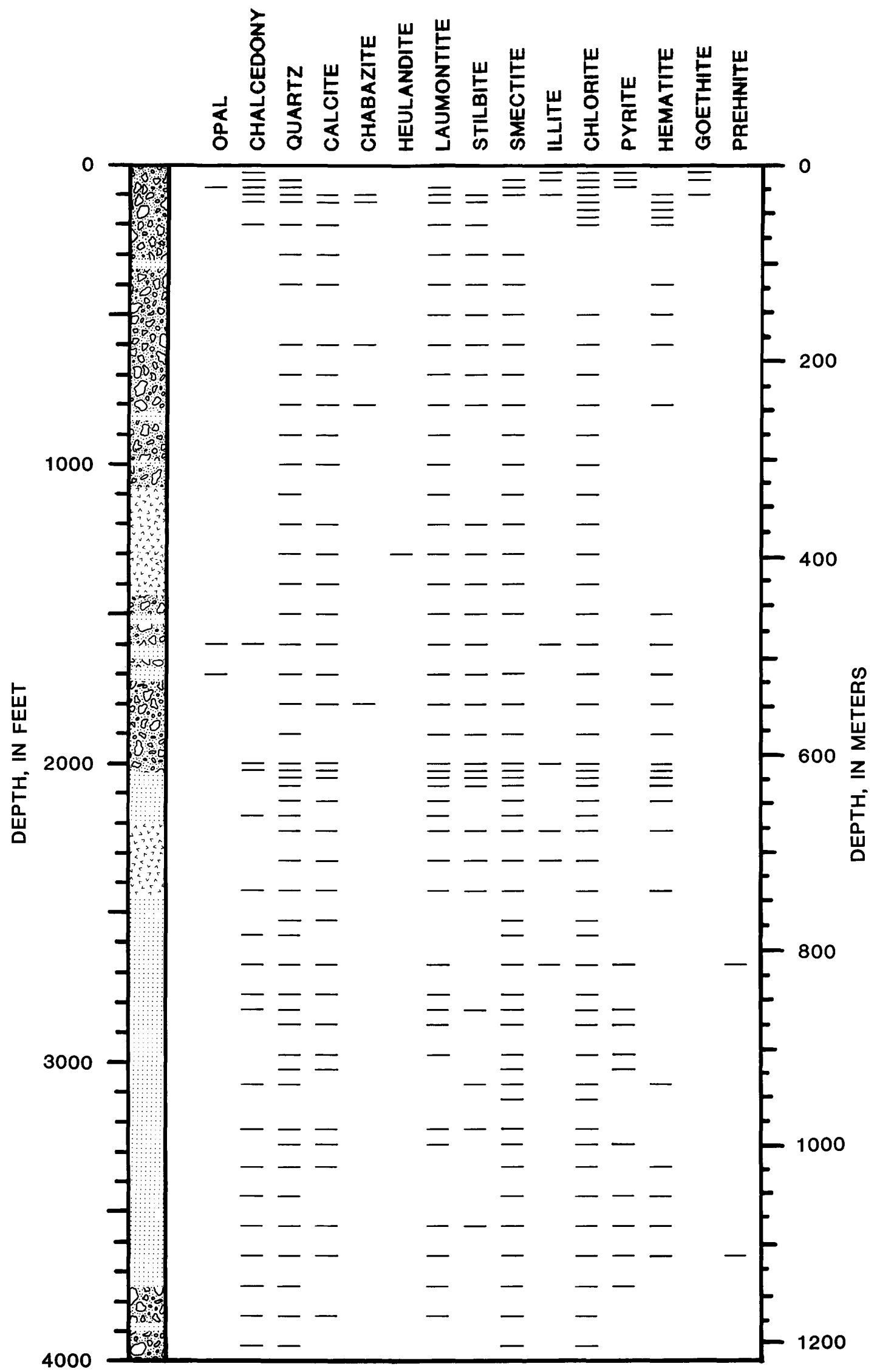

Stratigraphic representation of the Old Maid Flat drill hole showing the distribution of hydrothermal minerals. 


\section{CLEAR FORK (OMF-3)}

A stratigraphic section of the 402-m-deep NWNG Clear Fork drill hole was given in Covert and Meyer (1979). The upper $37 \mathrm{~m}$ of drill cuttings is described as mudflow debris. Between 37 and $317 \mathrm{~m}$, the drill hole penetrated mostly tuffaceous materials of the Rhododendron Formation. Below $317 \mathrm{~m}$ depth, the drill cuttings consist of fine grains that, according to Covert and Meyer (1979), are from basalt flows of the Columbia River Basalt Group and interlayered andesitic volcanic rocks.

Depth (m) Description of drill cuttings

0-37 Volcaniclastic debris. A mixture of angular to well-rounded, varicolored andesite grains. A few grains of quartz, chalcedony, and soft white zeolite (laumontite plus stilbite by XRD) are included with the mudflow debris.

37-317 Rhododendron Formation. Greenish-, grayish-, or brownish-colored crystal-lithic tuff. Crystals consist of plagioclase, quartz, magnetite, and occasionally pyroxene or hornblende. Some samples near the top of the interval contain a few andesite grains; below $232 \mathrm{~m}$ depth, most samples are a mixture of tuffaceous grains and angular to rounded andesite grains. Alteration minerals consist mostly of smectite and zeolite minerals (stilbite, laumontite, and minor mordenite), along with some chalcedony, chlorite, magnetite, hematite, and pyrite, and minor quartz and chrysocolla.

$317-402$

Columbia River Basalt Group. Samples are mostly fine-grained material and appear to consist of basalt grains, although Covert and Meyer (1979) reported andesite intervals. Hydrothermal quartz, chalcedony, stilbite and calcite grains are fairly abundant. Most XRD analyses contain smectite and minor laumontite, chlorite, siderite, hematite, and celadonite(?).

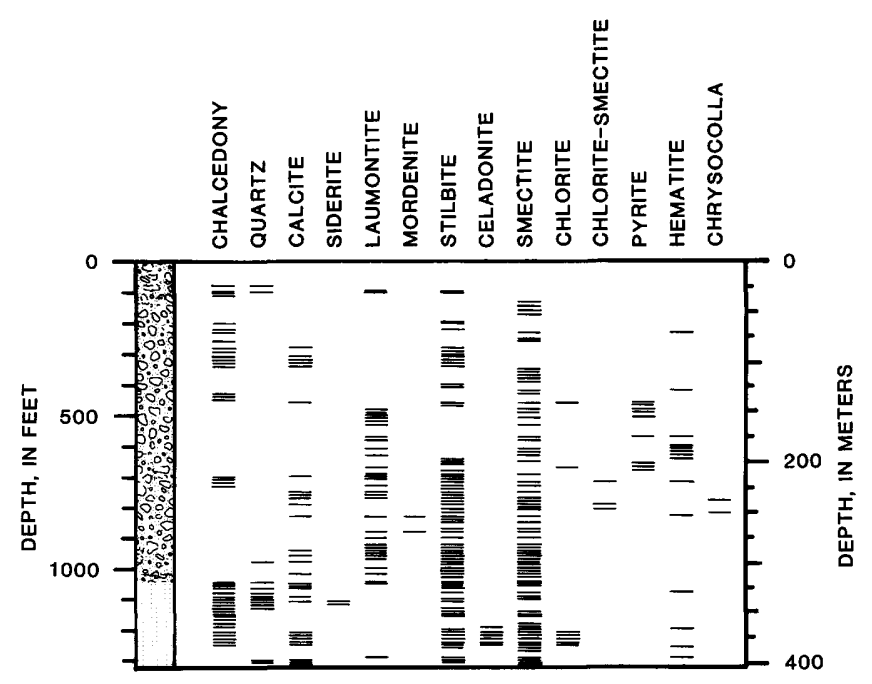

Stratigraphic representation of the Clear Fork drill hole showing the distribution of hydrothermal minerals.

\section{LOST CREFK (OMF-10)}

The 131-m-deep NWNG Lost Creek drill hole penetrated unit Qhd (Quaternary reworked debris consisting of postglacial detrituspartly morainal and partly water transported) mapped by Wise (1968) and unit Qhe (postglacial debris, in part) mapped by Wise (1969). From 0 to $73 \mathrm{~m}$, the drill cuttings are composed of this volcaniclastic debris. Below $73 \mathrm{~m}$ the drill cuttings consist of altered hornblende andesites(?) that may be correlative with the Rhododendron Formation.

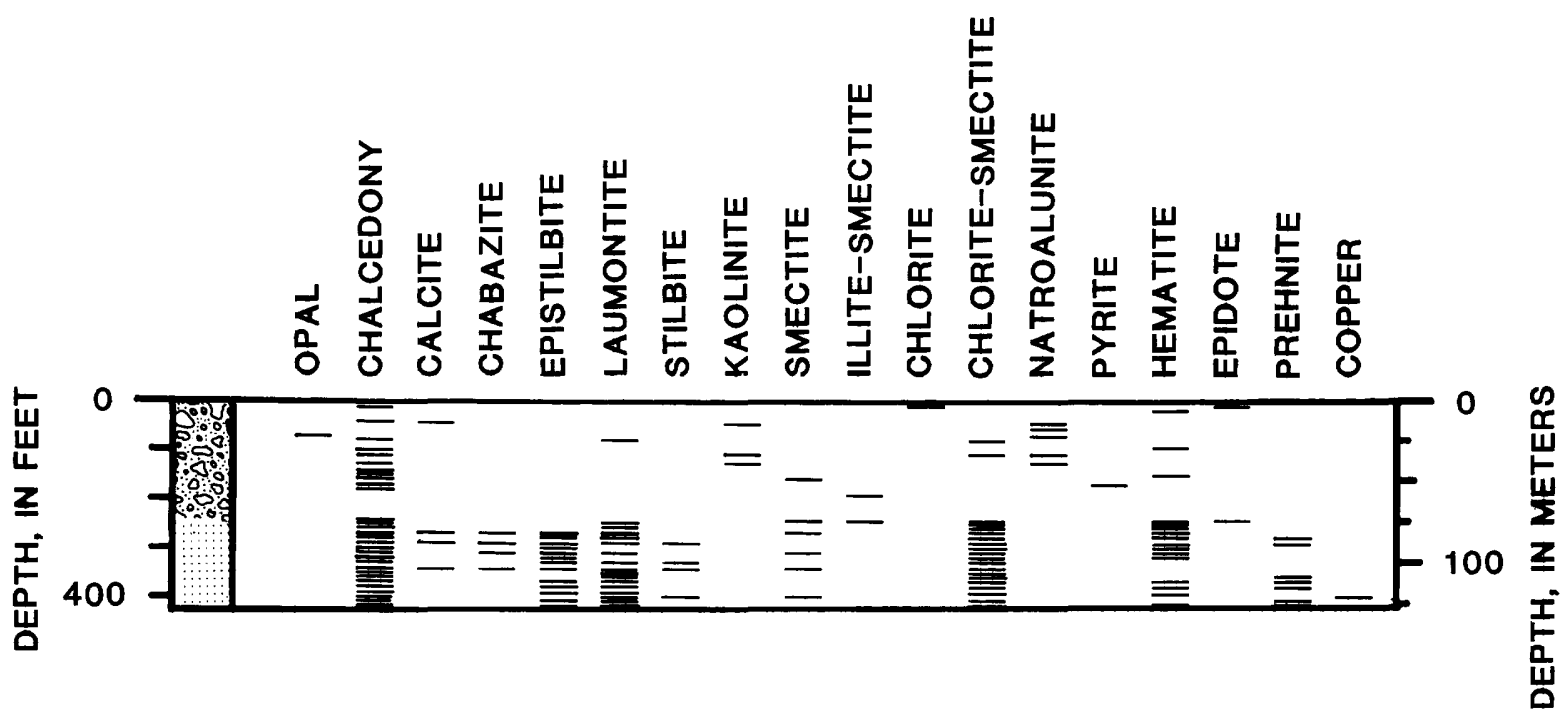

Stratigraphic representation of the Lost Creek drill hole showing the distribution of hydrothermal minerals. 
Depth (m) 0-73
Description of drill cuttings

Volcaniclastic debris. A mixture of varicolored, angular to well-rounded, pyroxene andesite grains consisting of plagioclase, $\alpha$-cristobalite, magnetite, clinopyroxene, orthopyroxene, and amphibole. Many samples have orange-to redstained or white-bleached grains that consist of hydrothermal chalcedony, smectite, natroalunite, kaolinite, opal, mixed-layer illite-smectite, and mixed-layer chlorite-smectite; minor epidote, chlorite, calcite, laumontite, pyrite, and hematite are also present.
73-131

Light-gray, altered, hornblende andesite(?) containing plagioclase $(\sim 1 \mathrm{~mm})$ and hornblende (up to $2 \mathrm{~mm}$ ) phenocrysts in a groundmass consisting of magnetite, plagioclase, hornblende, and chalcedony (discernable only in XRD). Minor clinopyroxene was detected in a few XRD analyses. Hydrothermal minerals include abundant mixed-layer chlorite-smectite, hematite, and zeolite minerals (laumontite, chabazite, stilbite, and epistilbite), as well as minor epidote, smectite, calcite, prehnite, and native copper.

\section{ZIGZAG RIVER (KIWANIS CAMP ROAD)}

Covert and Meyer (1979) showed a stratigraphic section of the 287-m-deep NWNG Zigzag River drill hole. The upper $12 \mathrm{~m}$ consists of a Quaternary Mount Hood andesite flow. Below $12 \mathrm{~m}$ depth, the drill hole penetrated quartz diorite of the Laurel Hill intrusion.

Depth $(m)$

$0-12$

$12-287$

\section{Description of drill cuttings}

Medium- to dark-gray, hypersthene andesite flow consisting of plagioclase, orthopyroxene, and magnetite.

Light- to medium-gray, porphyritic, hornblende, quartz diorite with plagioclase (up to $6 \mathrm{~mm}$ ) and hornblende phenocrysts. Space between pheno- crysts is filled by quartz and magnetite. Hydrothermal minerals are predominantly quartz, altered hornblende (chlorite and actinolite), epidote, magnetite, pyrite, and zeolite minerals (laumontite and stellerite(?) along with minor epistilbite, heulandite, scolecite, chabazite, and wairakite); some chalcopyrite, calcite, smectite, and illite(?) are also present.

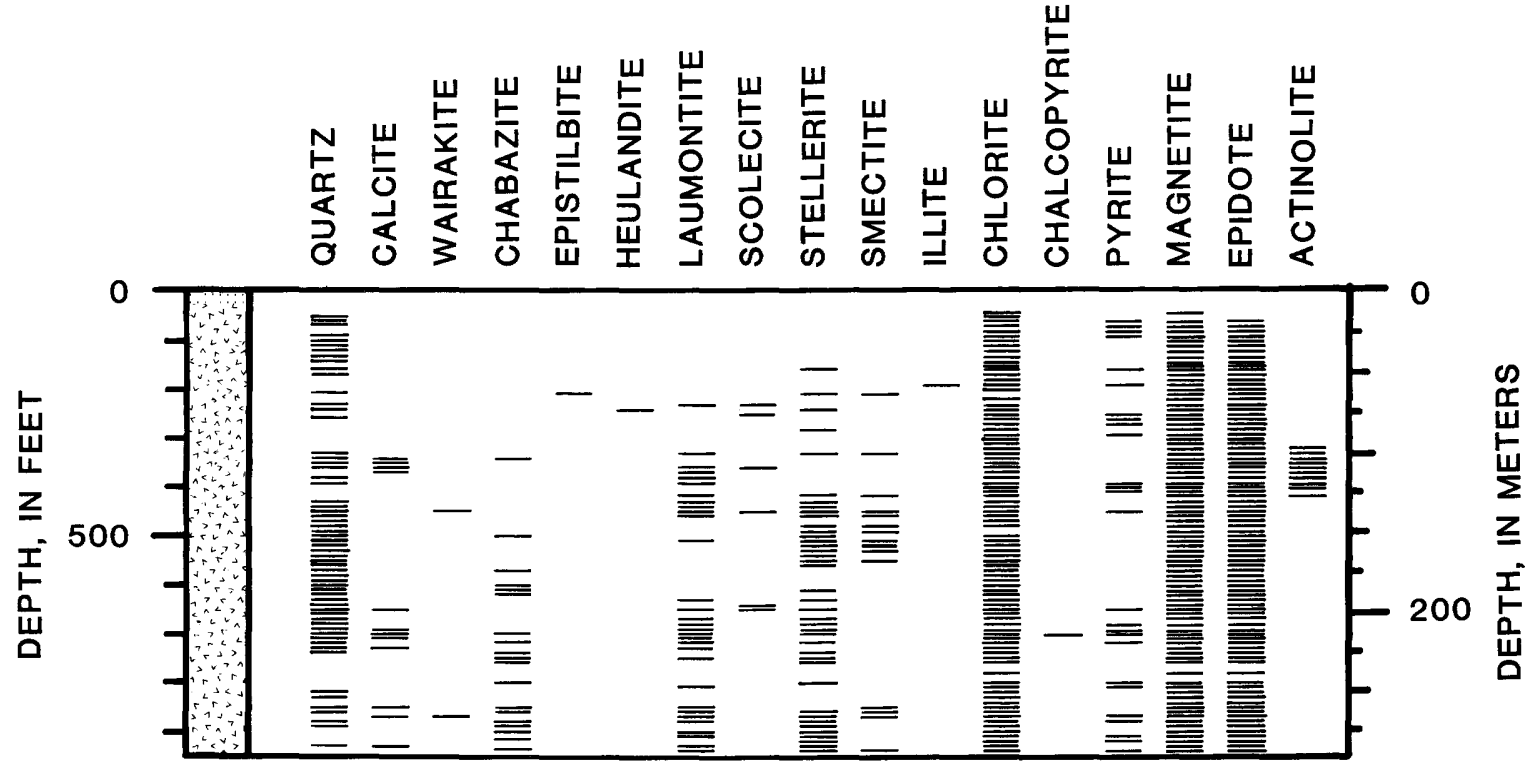

Stratigraphic representation of the Zigzag River drill hole showing the distribution of hydrothermal minerals. 


\section{LAUREL HILL}

The DOGAMI Laurel Hill drill hole encountered quartz diorite of the Laurel Hill intrusion throughout its $125 \mathrm{~m}$ depth.

Depth (m)

$0-125$

\section{Description of drill cuttings}

Light- to dark-gray, hornblende, quartz diorite containing hornblende (up to $3 \mathrm{~mm}$ ) and plagioclase (up to $2 \mathrm{~mm}$ ) phenocrysts in a matrix of plagioclase crystals and very minute quartz grains. Hornblende alters to chlorite or is replaced by actinolite; epidote, magnetite, zeolite minerals (stilbite, chabazite, epistilbite, and wairakite), and minor chalcopyrite occur as fracture fillings.

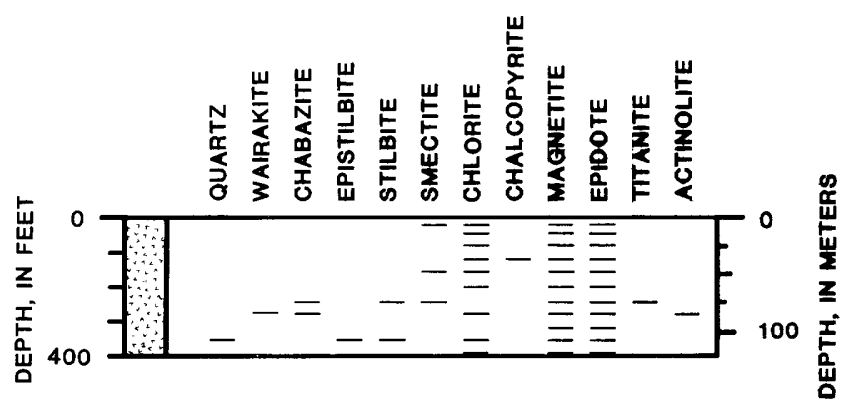

Stratigraphic representation of the Laurel Hill drill hole showing the distribution of hydrothermal minerals.

\section{STILL CREEK}

The 152-m-deep DOGAMI Still Creek drill hole was spudded in a Quaternary stream deposit. This deposit comprises the upper 18 $\mathrm{m}$ of drill cuttings; below $18 \mathrm{~m}$ depth, drill cuttings are a light- to dark-gray, hornblende, quartz microdiorite of the Still Creek intrusion.

\section{Depth (m) Description of drill cuttings}

0-18
Stream deposit consisting of a mixture of angular to rounded andesite and quartz microdiorite grains. Hydrothermal minerals include epidote, chlorite, magnetite, quartz, chalcedony, and smectite.
$18-152$

Light- to dark-gray, hornblende, quartz microdiorite. Hornblende is mostly altered to chlorite or is replaced by actinolite. Other alteration minerals are epidote and magnetite veins, quartz, zeolite minerals (chabazite, heulandite, laumontite, scolecite, stilbite and(or) stellerite(?), and wairakite), calcite, and clay minerals (smectite and illite).

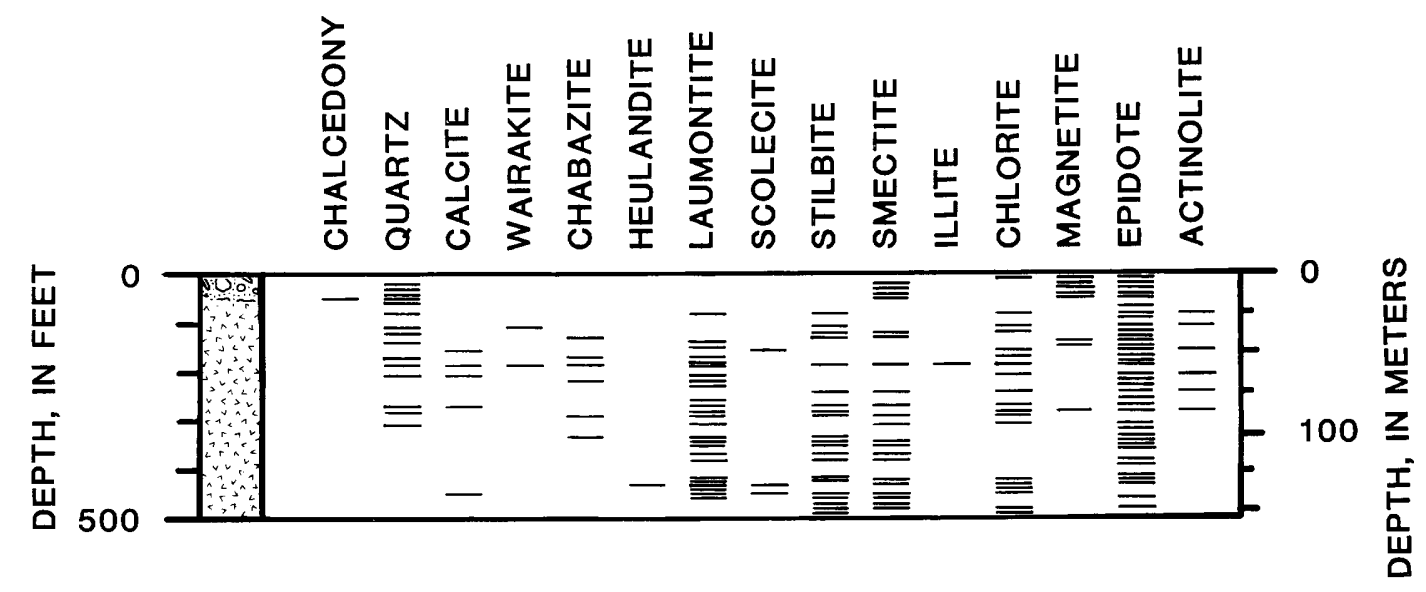

Stratigraphic representation of the Still Creek drill hole showing the distribution of hydrothermal minerals.

\section{SNOW BUNNY}

DOGAMI's 82.5-m-deep Snow Bunny drill hole was one of the first geothermal drill holes completed in the Mount Hood area. This drill hole was sited in a Quaternary andesite flow (Wise, 1968, 1969). The seven samples of drill cuttings recovered from about 12-m intervals appear to be from three different andesite flows. 
Depth (m)

Description of drill cuttings

12.2

$18.9-61.0$

73.2
Reddish, slightly vesicular, porphyritic, pyroxene andesite flow consisting of colorless plagioclase, and brown hypersthene; $\alpha$-cristobalite, tridymite, clinopyroxene, alkali-feldspar(?), and magnetite were also identified by XRD. The presence of alteration minerals hematite and gibbsite is probably due to weathering.

Light-gray, porphyritic, pyroxene andesite flow. Phenocrysts are colorless plagioclase, brown hypersthene, and minor light-green olivine; $\alpha$-cristobalite, tridymite, clinopyroxene, magnetite, and alkali-feldspar(?) were identified by XRD. Hydrothermal minerals are hematite(?), chalcedony, and halloysite.

Black, vesicular, pyroxene andesite flow with colorless plagioclase and brown hypersthene phenocrysts; magnetite, $\alpha$-cristobalite, and tridy- mite were identified by XRD. The only alteration mineral is hematite.

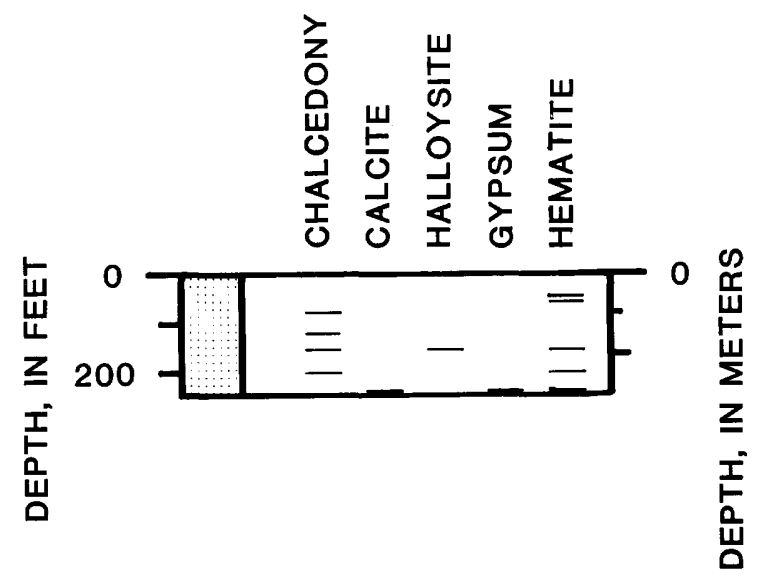

Stratigraphic representation of the Snow Bunny drill hole showing the distribution of hydrothermal minerals.

\section{MOUNT HOOD MEADOWS}

The 355-m-deep USGS Mount Hood Meadows drill hole was spudded in Quaternary andesite (Robison and others, 1982). The drill hole encountered numerous intervals of epiclastic debris units interlayered with thin andesitic or basaltic lava flows (Robison and others, 1981). The drill cuttings are nearly devoid of hydrothermal minerals.

$\operatorname{Depth}(m)$

Description of drill cuttings

0-17 Volcaniclastic debris. A mixture of varicolored, angular to rounded, pyroxene andesite grains consisting of plagioclase, orthopyroxene, magnetite, and $\alpha$-cristobalite. A few orange-stained, clayey grains contain hematite and illite.

17-24 Medium-gray, porphyritic, pyroxene andesite flow composed of plagioclase, clinopyroxene, magnetite, and $\alpha$-cristobalite.

24-30 Volcaniclastic debris. A mixture of angular to rounded, varicolored, andesite grains with some reddish iron oxide staining.

30-45 Medium-gray, hypersthene andesite flow with reddish oxidation. Plagioclase, $\boldsymbol{\alpha}$-cristobalite, orthopyroxene, magnetite, and hematite were identified by XRD.

45-53 Volcaniclastic debris. A mixture of angular to rounded, light- to medium-gray andesite grains with some reddish oxidation.

53-64 Medium- to dark-gray, hypersthene andesite flow.

64-72 Volcaniclastic debris. A mixture of angular to rounded, light- to dark-gray, pyroxene andesite grains.

72-82 Light-gray, porphyritic, hypersthene, andesite flow.
82-88

88-195

$195-204$

204-234

234-249

249-256

256-263

263-269

269-290

290-296
Black, basalt or basaltic andesite flow.

Volcaniclastic debris. A mixture of angular to rounded, varicolored, andesite grains with a few bleached or orange-stained grains that consist of plagioclase, $\boldsymbol{\alpha}$-cristobalite, tridymite, illite, kaolinite, opal, and hematite by XRD. One grain of calcite.

Dark-gray, basaltic andesite(?) flow.

Volcaniclastic debris. A mixture of varicolored, andesite grains with a few bleached or orangestained grains composed of plagioclase, $\alpha$ cristobalite, orthopyroxene, magnetite, smectite, kaolinite, hematite, and alunite by XRD.

Medium-gray, hypersthene andesite flow.

Volcaniclastic debris. A mixture of medium- and dark-gray, andesite grains with some reddish iron oxide staining.

Dark-gray to black basalt flow.

Volcaniclastic debris. Mixture of dark- to medium-gray, andesite grains; many grains have reddish-hematite staining.

Dark-gray, hypersthene andesite flow.

Volcaniclastic debris. A mixture of varicolored, andesite grains. Plagioclase, orthopyroxene(?), $\alpha$-cristobalite, magnetite, and hematite by XRD. 
296-305

Light- to medium-gray, hypersthene andesite flow. XRD analysis shows plagioclase, $\alpha$-cristobalite, orthopyroxene, magnetite, and hematite.

305-335

Volcaniclastic debris. A mixture of angular to rounded, medium-gray to black andesite grains plus a few bleached and orange-stained grains. XRD analysis of orange-stained grains shows plagioclase, $\alpha$-cristobalite, orthopyroxene, magnetite, hematite, illite, and smectite.

$335-347$

Dark-gray, porphyritic, basaltic andesite(?) flow. XRD analysis shows plagioclase, $\alpha$-cristobalite, orthopyroxene, and magnetite.

347-355 Volcaniclastic debris. A mixture of varicolored, andesite grains plus yellow-orange smectite grains. Some reddish oxidation due to hematite.

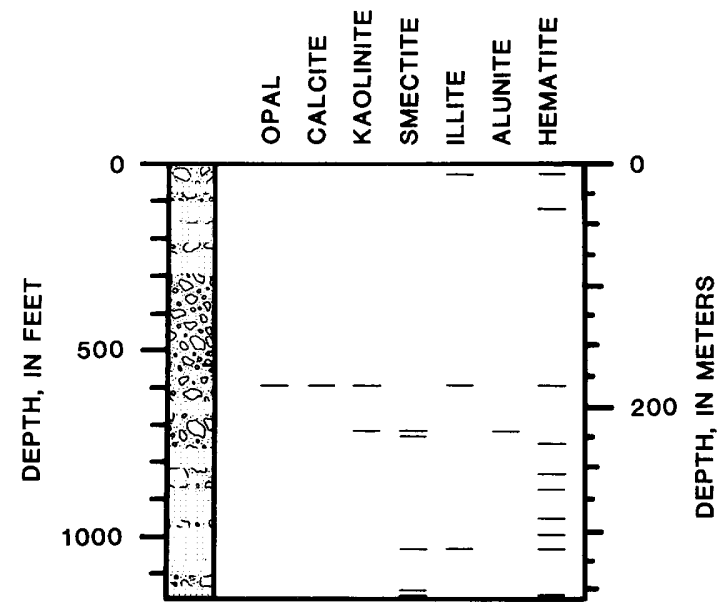

Stratigraphic representation of the Mount Hood Meadows drill hole showing the distribution of hydrothermal minerals.

\section{PUCCI CHAIRLIFT}

The 1,220-m-deep USGS Pucci Chairlift drill hole was sited near the base of the Pucci ski chairlift in unit Qhd (Quaternary clastic debris consisting of reworked detritus) mapped by Wise (1968) and unit Qhc (Quaternary clastic debris, largely pyroclastic) mapped by Wise (1969). The upper $737 \mathrm{~m}$ of the drill hole contains several volcaniclastic intervals that are interbedded with 19 grayish hypersthene andesite flows. Below $737 \mathrm{~m}$, Robison and others (written commun. 1981) indicated that the highly altered pyroxene andesite flows and interbedded volcaniclastic units are probably of Tertiary age. The description below is from Gannett and Bargar (1981). Gaps in the section (for example, 103.6-109.7 m) are due to lack of sample recovery.

Depth (m)

$0-67.1$

67.1-79.2

79.2-85.3

\section{Description of drill cuttings}

Colluvium and other volcanic debris. A mixture of subangular to rounded, chiefly medium-gray and reddish-brown, pyroxene andesite grains. Phenocrysts are colorless plagioclase and brown orthopyroxene. Considerable magnetite and $\alpha$-cristobalite, and traces of clinopyroxene and amphibole were identified by whole-rock XRD; vesicular oxidized clasts also contain hematite. Tridymite, alkali-feldspar(?), and opal were detected in XRD analyses of a few orange-stained and white-bleached pyroxene andesite grains. Gypsum was identified by SEM.

Medium-gray, pyroxene andesite. Phenocrysts consist of 5 percent colorless plagioclase ( 1 to $2 \mathrm{~mm}$ ) and 1 to 2 percent clear brown orthopyroxene (up to $3 \mathrm{~mm}$ ). $\alpha$-cristobalite, tridymite(?), quartz, magnetite, and alkali-feldspar(?) were identified by XRD.

Light-gray, slightly vesicular, pyroxene andesite. Contains up to 10 percent colorless plagioclase $(3 \mathrm{~mm})$ and 2 to 3 percent honeybrown orthopyroxene $(1 \mathrm{~mm})$. $\alpha$-cristobalite, magnetite, alkali-feldspar(?), hematite, and tridymite were identified by XRD.

97.5-103.6
Volcaniclastic debris. A mixture of subrounded to subangular, andesitic lavas; mostly light-gray, pyroxene andesite which has 5 to 10 percent clear plagioclase and slightly altered pyroxene phenocrysts. Plagioclase, orthopyroxene, clinopyroxene, amphibole(?), tridymite, $\alpha$-cristobalite(?), magnetite, and hematite were identified by XRD.

109.7-125 Light-gray, microvesicular, pyroxene andesite. Has 8 to 10 percent colorless plagioclase $(3 \mathrm{~mm})$ and 3 percent dark pyroxene ( 3 to $4 \mathrm{~mm}$ ) (clinopyroxene and orthopyroxene by XRD) phenocrysts. The groundmass contains disseminated magnetite; alkali-feldspar(?), $\alpha$-cristobalite, and tridymite were identified by XRD.

125-128.6 Medium-gray, highly porphyritic, pyroxene andesite. Phenocrysts are 15 to 20 percent colorless, often anhedral, plagioclase and 3 to 5 percent pyroxene (both clinopyroxene and orthopyroxene by XRD) ( 1 to $2 \mathrm{~mm}$ ). Hematite, magnetite, tridymite, $\alpha$-cristobalite, and alkali-feldspar(?) were also identified by XRD.

134.7-140.8 Volcaniclastic debris. Mostly subrounded, pyroxene andesites. XRD analysis of one light-gray, andesite grain showed reflections for plagioclase, $\alpha$-cristobalite, magnetite, amphibole, clinopyroxene, and orthopyroxene.

140.8-146.9 Dark-reddish-gray to red-black, glassy, vesicular, pyroxene andesite. Phenocrysts are 5 
146.9-165.2 Reddish-gray (oxidized), vesicular, hypersthene andesite. Phenocrysts consist of 3 to 5 percent colorless plagioclase $(4 \mathrm{~mm})$ and 1 to 2 percent brown hypersthene $(1 \mathrm{~mm})$. XRD reflections for $\alpha$-cristobalite, magnetite, hematite, and clinopyroxene(?) were observed.

165.2-172.8 Medium-gray, fine-grained, pyroxene andesite. Phenocrysts are 5 percent colorless plagioclase ( 2 to $3 \mathrm{~mm}$ ) and $<1$ percent pyroxene $(1 \mathrm{~mm})$. Plagioclase, orthopyroxene, $\alpha$-cristobalite, magnetite, and alkalifeldspar(?) were identified by XRD.

184.4-202.7 Medium- to light-gray, pyroxene andesite. Has two sizes of colorless plagioclase phenocrysts ( $1 \times 1 \mathrm{~mm}$ and $1 \times 0.1 \mathrm{~mm}$ ) compose 3 to 5 percent of sample; another 1 percent of phenocrysts are clear brown orthopyroxene (1 mm). XRD analyses contain reflections for $\alpha$-cristobalite, clinopyroxene, magnetite, and alkali-feldspar(?).

202.7-216.4 Medium-gray, pyroxene andesite. Phenocrysts are composed of 10 percent colorless plagioclase (1 to $2 \mathrm{~mm}$ ) and 1 to 2 percent brown orthopyroxene $(0.5$ to $1 \mathrm{~mm})$. Magnetite, tridymite, and $\alpha$-cristobalite were identified by XRD. One sample from $215.5 \mathrm{~m}$ contained a trace of smectite.

216.4-374.9 Volcaniclastic volcanic debris: colluvium and mudslide material typical of large stratovolcanoes. A mixture of angular to subangular, pyroxene, andesite grains that are various shades of gray, black, brown, and red with a few orange-stained and white-bleached grains sprinkled throughout. XRD and binocular microscope studies show that most of the grains consist of colorless plagioclase and brown orthopyroxene phenocrysts, magnetite, and $\alpha$-cristobalite; minor constituents may include hematite, clinopyroxene, amphibole, tridymite, and alkali-feldspar(?). The interval was subdivided on the basis of the presence or absence of several hydrothermal alteration minerals.

216.4-236.2 chalcedony, kaolinite, smectite, pyrite, $10-\AA$ mica.

236.2-272.8 unaltered except for some iron oxide staining.

272.8-338.3 calcite, chalcedony, kaolinite, B-cristobalite, sme-ctite, natroalunite, opal, pyrite, 10 $\AA$ mica.

338.3-356.6 unaltered.
356.6-374.9 chalcedony, pyrite.

374.9-393.2 Light-gray, slightly vesicular, pyroxene andesite. Phenocrysts are colorless plagioclase, brownish orthopyroxene, and rare hornblende; the groundmass contains finely disseminated magnetite. Clinopyroxene, hematite, and $\alpha$-cristobalite were identified by XRD.

393.2-513.6 Volcaniclastic volcanic debris: colluviuim and landslide material; possibly minor fluvial material. Mixture of angular to subangular, mostly medium-gray, pyroxene andesite, and subordinant light-gray, dark-gray, black, reddish, and brown pyroxene andesite grains. Phenocrysts are colorless plagioclase, brown orthopyroxene, and green clinopyroxene. Magnetite, tridymite, amphibole(?), and alkali-feldspar(?) were detected by XRD. Most samples have a few orange-stained or whitebleached grains that contain one or more of the alteration minerals: calcite, chalcedony, or pyrite.

513.6-522.7 Medium-dark-gray, pyroxene andesite. Phenocrysts consist of $<5$ percent colorless plagioclase $(1 \mathrm{~mm})$ and rare, small $(<0.5 \mathrm{~mm})$, brown orthopyroxene crystals. XRD analyses have reflections for $\alpha$-cristobalite and tridymite.

522.7-554.7 Volcaniclastic debris. Mixture of subangular to subrounded grains of light- medium- and dark-gray, brownish, reddish vesicular, and black glassy andesite. Plagioclase, orthopyroxene, $\alpha$-cristobalite, hornblende, tridymite, magnetite, and alkali-feldspar(?) were identified by XRD. A few frosted calcite and white- or pink-silica grains were observed. $\alpha$-cristobalite, smectite, kaolinite, $10 \AA$ mica or illite, and hematite were identified by XRD of iron-stained and siliceous grains.

554.7-563.9 Reddish-gray to medium-gray, porphyritic, pyroxene andesite. Phenocrysts consist of 15 percent colorless plagioclase $(1 \mathrm{~mm})$, often occurring as glomerocrysts, and 3 to 5 percent brown hypersthene $(0.5 \mathrm{~mm})$. Also, $\alpha$ cristobalite, tridymite, clinopyroxene and hematite were identified by XRD.

563.9-573.0 Black- to brownish-black, diktytaxitic, olivine(?) basalt. Many grains are microvesicular and are frequently quite oxidized. Phenocrysts are 1 to 2 percent colorless plagioclase $(0.5 \mathrm{~mm})$ and very minor yellowgreen olivine(?). $\alpha$-cristobalite and orthopyroxene identified by XRD.

573.0-585.2 Volcaniclastic debris. A mixture of subangular to rounded, light- and medium-gray, andesite grains that contain plagioclase, $\alpha$ cristobalite, orthopyroxene, clinopyroxene, 
tridymite(?), and hornblende identified by XRD analyses. Calcite grains also occur in most samples.

585.2-597.4 Medium- to dark-gray, porphyritic, pyroxene andesite with 7 to 12 percent colorless plagioclase $(0.5 \mathrm{~mm})$ phenocrysts. $\alpha$-cristobalite, clinopyroxene, hematite, tridymite, chalcedony, calcite, pyrite, and smectite were identified by XRD.

597.4-602 Volcaniclastic material consisting of a mixture of varicolored, subangular to rounded andesite grains; some of which are altered. Plagioclase, $\alpha$-cristobalite, tridymite, smectite, calcite and opal(?) were identified by XRD.

602-611.1 Dark- to medium-gray, hypersthene andesite. Phenocrysts consist of 10 percent colorless plagioclase (1 to $1.5 \mathrm{~mm}$ ) and 2 to 3 percent clear brown hypersthene $(<0.5 \mathrm{~mm})$. The groundmass is crystalline and contains plagioclase, orthopyroxene, $\alpha$-cristobalite, tridymite, and hematite identified by XRD.

611.1-630.9 Volcaniclastic material. A mixture of varicolored, angular to rounded andesite grains. Minerals identified by XRD are $\alpha$ cristobalite and several hydrothermal alteration minerals: calcite, chalcedony, smectite, hematite, natroalunite, and kaolinite(?).

630.9-640.1 Medium- to dark-gray, pyroxene andesite. Phenocrysts consist of 10 percent colorless plagioclase $(1.0 \mathrm{~mm})$ and 2 percent hypersthene $(0.5 \mathrm{~mm}) . \alpha$-cristobalite, clinopyroxene and smectite also were detected by XRD. Has some oxidized clasts and calcite.

640.1-646.2 Volcaniclastic debris consisting of varicolored, subangular to subrounded andesite grains. XRD analyses show the presence of calcite, hematite, chalcedony, and natroalunite hydrothermal minerals plus $\alpha$-cristobalite.

646.2-653.8 Brownish-gray, pyroxene andesite. Phenocrysts are $\sim 7$ percent colorless plagioclase $(0.5 \mathrm{~mm})$ and $<1$ percent very small $(0.1$ $\mathrm{mm}$ ) pyroxene crystals. $\alpha$-cristobalite and tridymite also were identified by XRD.

653.8-691.9 Volcaniclastic debris. A mixture of varicolored, subangular to subrounded andesite grains (rarely rounded). $\alpha$-cristobalite was identified by XRD analyses. Hematite is very abundant; other hydrothermal minerals include calcite, chalcedony, natroalunite, kaolinite, smectite, quartz, and $10-\AA$ mica.

691.9-698.0 Dark-gray, slightly vesicular, hypersthene andesite. Phenocrysts consist of colorless plagioclase $(1 \mathrm{~mm})$ (10 to 15 percent), brown hypersthene $(0.2$ to $0.5 \mathrm{~mm})$, often as glomerocrysts, and rare larger augite crystals. Groundmass(?) $\alpha$-cristobalite was detected by XRD. Hematite coats $\sim 20$ percent of chips. Traces of calcite, green clay (smectite?), and chalcedony occur as hydrothermal alteration minerals.

698.0-713.2 Volcaniclastic debris. A mixture of varicolored, subangular to subrounded andesite grains. Minerals identified by XRD include $\alpha$-cristobalite plus hydrothermal alteration minerals: smectite, and chalcedony. The interval also contains calcite, hematite, and green clay (smectite?).

713.2-731.5 Dark-gray to orange-red (oxidized), vesicular, pyroxene andesite. Most chips are 75 percent oxidized (hematite?). Phenocrysts are 25 to 30 percent colorless plagioclase $(1.0 \mathrm{~mm})$ and 3 to 5 percent clear brown orthopyroxene (0.1-0.5 mm), often as glomerocrysts. The groundmass appears glassy, but contains some $\alpha$-cristobalite identified by XRD. Hydrothermal alteration minerals identified by XRD include: chalcedony, hematite, calcite, and smectite.

731.5-737.6 Volcaniclastic debris. A mixture of varicolored, subangular to rounded andesite grains. A few grains contain calcite, chalcedony(?), and white and green clay (smectite?).

737.6-755.9 Orange, pyroxene andesite with some autoclastic aspects. Phenocrysts are white plagioclase. Interpretation of XRD analyses suggests that clinopyroxene has mostly been altered to green smectite, and if $\alpha$-cristobalite were present, it has been altered to chalcedony. The groundmass is soft and altered to iron oxide and clay. Hydrothermal alteration minerals, deposited in open spaces of fractures and cavities, are: calcite, chalcedony (in part colliform), stilbite, laumontite, hematite, and smectite (identified by XRD).

755.9-780.3 Dark-brownish-gray (rarely greenish gray), pyroxene andesite. Phenocrysts are 2 to 3 percent colorless, red- or green-stained plagioclase ( 1 to $2 \mathrm{~mm}$ ). Clinopyroxene, orthopyroxene(?), smectite, hematite, and quartz(?) or chalcedony(?) were identified from XRD analyses. Mafic minerals appear to be mostly altered to blue-green smectite. Several XRD analyses of fracture fillings (including green clay) have reflections for smectite, stilbite, laumontite, chalcedony, and calcite. One grain has a crust of euhedral magnetite crystals.

780.3-803.2 Volcaniclastic debris. A mixture of hematitealtered, subangular to subrounded pyroxene andesite grains. Fracture fillings of white zeolite minerals (laumontite, heulandite, and stilbite), chalcedony, green clay (smectite), and calcite were identified by XRD. 
803.2-851.9 Dark-green- to dark-greenish-brown, hydrothermally altered, pyroxene andesites. Plagioclase phenocrysts are cloudy to white. Plagioclase, clinopyroxene, quartz(?) or chalcedony(?), smectite, and hematite were identified by whole-rock XRD analyses. Fracture-filling hydrothermal minerals consist of stilbite, laumontite, calcite, chalcedony, and smectite. One sample also has a cavity(?) filling of colorless, crystalline quartz.

851.9-862.6 Volcaniclastic material consisting of a mixture of subangular to subrounded pyroxene andesite grains. Hydrothermal minerals in altered andesite grains, fractures, and vein fillings include calcite, chalcedony, hematite, heulandite, smectite, laumontite, and chlorite.

862.6-885.4 Moderate brownish-red to grayish-green, fine-grained, pyroxene andesite. Plagioclase phenocrysts are colorless to cloudy; pyroxene is altered to bluish-green smectite. Alteration minerals are chalcedony, hematite, quartz, calcite, stilbite, laumontite, and smectite.

885.4-894.6 Volcaniclastic material. A mixture of hydrothermally altered, subangular to subrounded andesitic-grains. Hydrothermal minerals identified by XRD include hematite, stilbite, chalcedony, smectite, calcite, and laumontite.

894.6-912.9 Dark-greenish-gray to dark-brownish-gray, hydrothermally altered, pyroxene andesite. The groundmass is soft and has been altered to smectite. Rare $1 \mathrm{~mm}$ cloudy plagioclase phenocrysts are present; $\alpha$-cristobalite was identified by XRD analysis. Drill cuttings contain green smectite fracture fillings. Other hydrothermal minerals, stilbite, chalcedony, quartz, hematite, calcite, and mordenite, were identified by XRD.

912.9-920.5 Volcaniclastic debris consisting of hydrothermally altered, subangular to subrounded, andesite grains. Alteration minerals are chalcedony, stilbite, mordenite, smectite, hematite, and epistilbite.

920.5-932.7 Moderate, reddish-brown, intensely altered andesite. The original texture is obscured, but it appears to have been porphyritic. Drillcutting samples contain much hydrothermal stilbite, calcite, chalcedony, mordenite, hematite, laumontite, and smectite.

932.7-941.8 Epiclastic material. A mixture of subangular to subrounded, andesite grains. Hydrothermal minerals include stilbite, laumontite, mordenite, hematite, smectite, and chalcedony.
941.8-1,039.4 A thick series of altered, dark-greenish-gray to grayish-olive-green, porphyritic, pyroxene andesites. Phenocrysts are 5 to 10 percent plagioclase ( 2 to $5 \mathrm{~mm}$ ), rarely up to $8 \mathrm{~mm}$; pyroxenes (orthopyroxene? by XRD) are seldom present and are mostly altered to green smectite. Groundmass glass probably was devitrified to $\alpha$-cristobalite, but later was hydrothermally altered to chalcedony(?). Alteration varies from minor hematite and smectite altered groundmass to extremely intense and apparently fracture controlled alteration. Intensely altered clasts, which may account for $\sim 50$ percent of some sample intervals, consist predominantly of varicolored mottled smectite with evidence of shearing and microbrecciation. Other hydrothermal fracture or vug minerals include mordenite, stilbite, chalcedony, calcite, and laumontite.

1,039.4-1,091.2 A thick section of subangular to subrounded, epiclastic, andesitic material; probably a series of mudflows or colluvial debris. Most samples are a mixture of varicolored andesite grains, although some sample intervals are dominated by one grain color. Hydrothermal minerals are smectite, mordenite, chalcedony, stilbite, calcite, laumontite, hematite, and quartz.

1,091-1,100.3 Dark-greenish-gray to grayish-black, hydrothermally altered, pyroxene andesite. Phenocrysts (10 percent) often consist of red-stained plagioclase (up to $1 \mathrm{~cm}$ but generally smaller) and 5 to 7 percent pyroxene $(\sim 1 \mathrm{~mm})$. Apparently a groundmass of devitrified $\alpha$-cristobalite(?) was hydrothermally altered to chalcedony(?). Other hydrothermal minerals identified are smectite, calcite, stilbite, and mordenite.

1,100.3-1,143 Volcaniclastic material similar to interval at $1,039.4$ to $1,091.2 \mathrm{~m}$. A mixture of subangular to subrounded, varicolored, andesitic grains. Contains some of the most intensely altered lavas encountered in the drill hole. Secondary minerals are calcite, stilbite, chalcedony, smectite, mordenite, laumontite, and pyrite.

1,143-1,221.1 Thick, dark-grayish-green to grayish-brown, pyroxene andesite section. Contains 15 to 20 percent cloudy or clear to slightly green or red-stained plagioclase phenocrysts $(\sim 1 \mathrm{~mm}$ : some up to $2 \mathrm{~mm}$ ) and 3 to 5 percent mostly altered pyroxene (hypersthene and augite) $(0.5 \mathrm{~mm})$. Groundmass is fairly coarse. Secondary minerals are smectite, stilbite, laumontite, calcite, chalcedony, pyrite, mordenite, and traces of chlorite. 


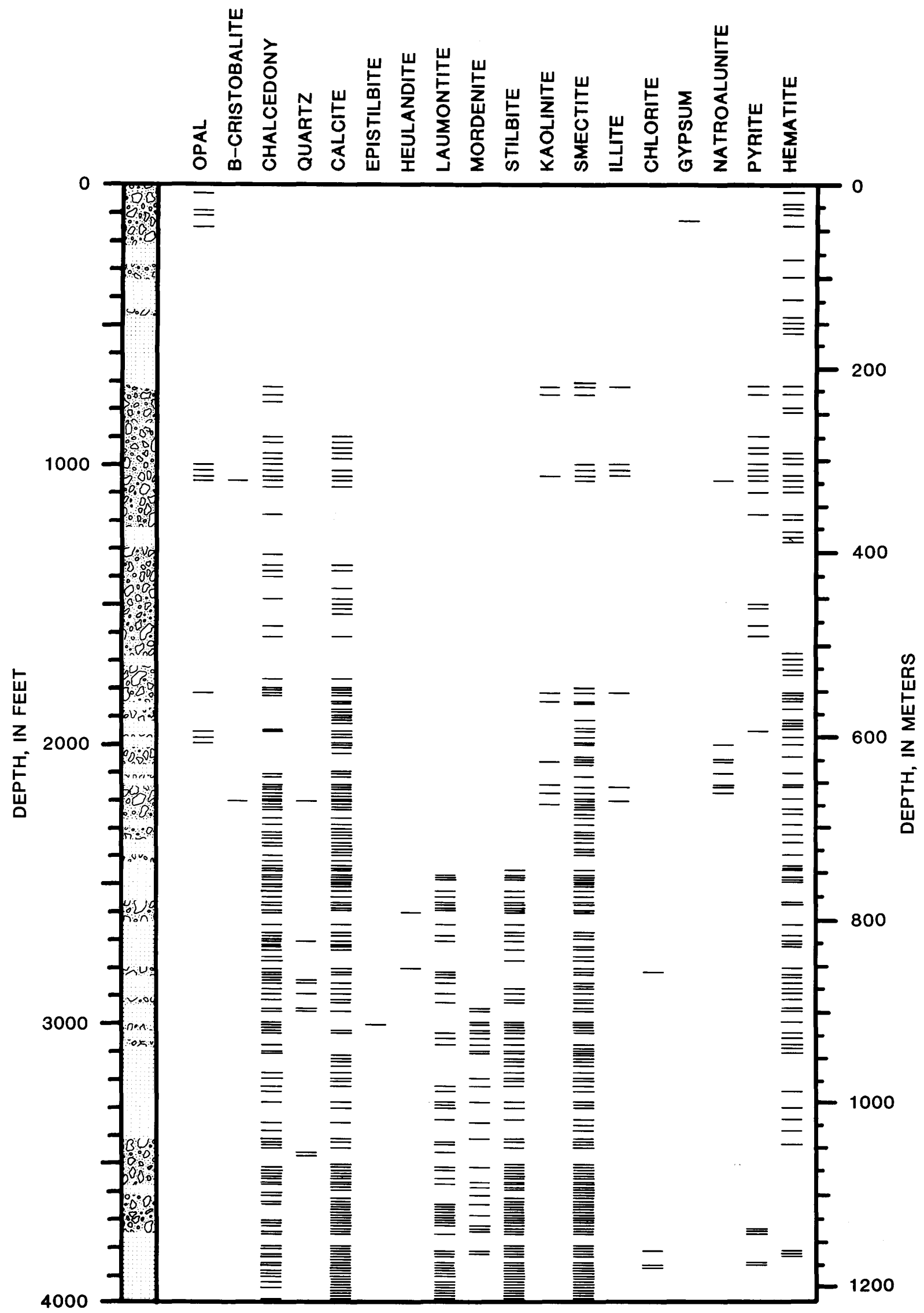

Stratigraphic representation of the Pucci Chairlift drill hole showing the distribution of hydrothermal minerals. 


\section{APPENDIX B. HYDROTHERMAL MINERALS IDENTIFIED FROM GEOTHERMAL DRILL HOLES AND OUTCROPS IN THE MOUNT HOOD AREA.}

[Identified by binocular microscope, petrographic microscope, and X-ray diffraction analyses. Leaders (--), mineral not detected]

\begin{tabular}{|c|c|c|c|c|c|c|c|c|c|c|c|c|c|c|c|c|c|c|c|c|}
\hline $\begin{array}{l}\text { Drill hole and } \\
\text { outcrop designation }^{1}\end{array}$ & 1 & 2 & 3 & 4 & 5 & 6 & 7 & 8 & 9 & 10 & 11 & 12 & 13 & A & B & $\mathrm{C}$ & D & $\mathbf{E}$ & $\mathrm{F}$ & $\mathbf{G}$ \\
\hline \multicolumn{21}{|l|}{ Silica minerals } \\
\hline Chalcedony - & $\mathbf{X}$ & -- & $\mathbf{X}$ & $\mathbf{X}$ & $\mathbf{X}$ & $\mathbf{X}$ & $\mathbf{X}$ & -- & - & $\mathbf{X}$ & $\mathbf{X}$ & -- & $\mathbf{X}$ & $\mathbf{x}$ & -- & -- & $\mathbf{X}$ & $\mathbf{X}$ & $\mathbf{x}$ & $\mathbf{X}$ \\
\hline Quartz & - & -- & - & $\mathrm{X}$ & $\mathrm{X}$ & $\mathbf{X}$ & - & $\mathbf{x}$ & $\mathrm{X}$ & $\mathrm{X}$ & - & -- & $\mathbf{X}$ & $\mathrm{x}$ & $\mathbf{X}$ & $\mathbf{X}$ & $\mathrm{X}$ & $\mathrm{X}$ & $\mathrm{X}$ & $\mathbf{X}$ \\
\hline \multicolumn{21}{|l|}{ Carbonate minerals } \\
\hline Manganoan calcite & -- & $\mathbf{X}$ & -- & -- & -- & -- & -- & -- & -- & - & - & - & $\mathbf{X}$ & $\mathbf{X}$ & -- & -- & -- & -- & -- & -- \\
\hline Cerussite & -- & -- & -- & -- & -- & -- & -- & -- & -- & -- & -- & -- & - & $\mathbf{x}$ & $\mathbf{X}$ & - & -- & -- & -- & -- \\
\hline Rhodochrosite - & -- & -- & $\mathrm{X}$ & -. & -- & -- & -- & -- & -- & -- & -- & -- & -- & - & -- & -- & -- & -- & -- & -- \\
\hline Siderite - & -- & -- & $\mathrm{X}$ & - & -- & $\mathbf{X}$ & - & -- & - & -- & -- & - & -- & $\mathbf{X}$ & -- & -- & - & -- & -- & -- \\
\hline \multicolumn{21}{|l|}{ Zeolite minerals } \\
\hline Chabazite - & - & -- & - & - & $\mathbf{x}$ & -- & $\mathbf{X}$ & $\mathbf{X}$ & $\mathbf{X}$ & $\mathbf{X}$ & -- & -- & -- & -- & $\mathbf{X}$ & -- & -- & $\mathbf{X}$ & -- & -- \\
\hline Laumontite --.--- & -- & -- & -- & - & $\mathbf{X}$ & $\mathbf{X}$ & $\mathbf{X}$ & $\mathbf{X}$ & -- & $\mathrm{X}$ & -- & -- & $\mathbf{X}$ & -- & -- & $\mathbf{X}$ & -- & $\mathbf{X}$ & $\mathbf{X}$ & -- \\
\hline Mordenite - & -- & $\mathbf{X}$ & -- & -- & -- & $\mathbf{X}$ & -- & -- & -- & - & -- & -- & $\mathbf{X}$ & - & -- & -- & $\mathbf{X}$ & -- & -- & $\mathbf{X}$ \\
\hline Scolecite & -- & -- & -- & - & -- & - & -- & $\mathbf{X}$ & -- & $\mathbf{X}$ & -- & -- & - & -- & -. & -- & -- & $\mathbf{X}$ & $\mathbf{X}$ & -- \\
\hline Stellerite(?) ----- & - & -- & -- & - & - & -- & -- & $\mathrm{X}$ & -- & - & -- & - & -- & -- & - & -- & -- & -- & -- & - \\
\hline Stilbite & -- & -- & -- & $\mathbf{X}$ & $\mathrm{X}$ & $\mathbf{X}$ & $\mathbf{X}$ & -- & $\mathbf{X}$ & $\mathbf{X}$ & -- & -- & $\mathbf{X}$ & -- & -- & -- & -- & $\mathbf{X}$ & - & -- \\
\hline Wairakite -..... & -- & -- & -- & - & - & - & - & $\mathbf{X}$ & $\mathbf{X}$ & $\mathrm{X}$ & -- & -- & - & -- & - & -- & -- & $\mathrm{X}$ & -- & - \\
\hline \multicolumn{21}{|l|}{ Clay minerals } \\
\hline Halloysite - & - & - & - & -- & - & - & -- & -- & -- & -- & $\mathrm{X}$ & - & -- & - & -- & -- & -- & -- & - & -- \\
\hline (2-3. & $\mathbf{x}$ & - & $\mathbf{x}$ & - & - & -- & $\mathbf{X}$ & -- & -- & -- & - & $\mathbf{X}$ & $\mathbf{X}$ & $\mathrm{x}$ & -- & $\mathbf{x}$ & -- & -- & $\mathbf{x}$ & -- \\
\hline (2) & - & -- & -- & - & -- & $\mathbf{X}$ & -- & -- & -- & -- & -- & - & -- & -- & -- & -- & $\mathbf{X}$ & -- & -- & - \\
\hline Smectite - & $\mathbf{X}$ & $\mathbf{X}$ & $\mathbf{X}$ & $\mathbf{X}$ & $\mathbf{x}$ & $\mathbf{X}$ & $\mathbf{X}$ & $\mathbf{X}$ & $\mathbf{X}$ & $\mathbf{X}$ & -- & $\mathbf{X}$ & $\mathbf{x}$ & - & $\mathbf{X}$ & $\mathbf{X}$ & $\mathbf{X}$ & $\mathrm{X}$ & $\mathbf{X}$ & $\mathbf{X}$ \\
\hline Illite - & -- & -- & - & $\mathbf{X}$ & $\mathbf{X}$ & - & -- & $\mathrm{X}$ & -- & $\mathbf{X}$ & - & $\mathbf{X}$ & $\mathrm{X}$ & $\mathbf{X}$ & $\mathbf{X}$ & -- & - & $\mathbf{X}$ & $\mathbf{X}$ & $\mathbf{X}$ \\
\hline Illite-Smectite & -- & -- & - & $\mathbf{X}$ & -- & -- & $\mathbf{X}$ & -- & -- & -- & -- & -- & -- & $\mathbf{X}$ & $\mathbf{X}$ & $\mathbf{X}$ & -- & -- & +- & - \\
\hline Natrojarosite & $\mathbf{x}$ & - & - & -- & -- & -- & -- & -- & -- & - & -- & -- & -- & -- & - & -- & -- & -- & -- & -- \\
\hline Anglesite -...- & -- & -- & -- & -- & -- & -- & -- & -- & -- & -- & -- & -- & -- & $\mathbf{X}$ & -- & -- & -- & -- & -- & -- \\
\hline \multicolumn{21}{|l|}{ Sulfide minerals } \\
\hline Chalcopyrite & - & -- & - & - & -- & -. & -- & $\mathbf{X}$ & $\mathbf{X}$ & -- & -. & - & -- & - & $\mathbf{X}$ & - & - & $\mathbf{X}$ & -- & -- \\
\hline Galena -----. & -- & - & - & -- & -- & -. & - & - & - & -- & - & -- & -- & $\mathbf{X}$ & $\mathbf{X}$ & -- & - & - & -- & -- \\
\hline Pyrite ..... & $\mathbf{x}$ & $\mathbf{X}$ & $\mathbf{x}$ & $\mathrm{X}$ & $\mathbf{x}$ & $\mathbf{X}$ & $\mathbf{X}$ & $\mathbf{X}$ & -- & -- & -- & -- & $\mathbf{X}$ & $\mathbf{X}$ & $\mathrm{X}$ & $\mathbf{X}$ & -- & -- & $\mathbf{X}$ & $\mathbf{X}$ \\
\hline Sphalerite - & - & - & - & - & - & - & - & - & - & -- & -- & -- & - & $\mathbf{X}$ & $\mathrm{X}$ & - & -- & -- & - & - \\
\hline \multicolumn{21}{|l|}{ Iron oxide and hydroxide minerals } \\
\hline Amorphous FeO & $\mathbf{x}$ & -- & -- & $\mathbf{X}$ & -- & - & -- & -- & - & -- & - & - & $\mathbf{X}$ & -- & - & -- & -- & - & $\mathbf{x}$ & -- \\
\hline Goethite - & - & -- & -- & -- & $\mathbf{X}$ & - & -- & -- & -- & -- & -- & -- & -- & $\mathbf{X}$ & -- & -- & -- & -- & $\mathbf{X}$ & $\mathbf{x}$ \\
\hline Hematite - & -- & $\mathbf{X}$ & $\mathbf{X}$ & $\mathbf{X}$ & $\mathbf{X}$ & $\mathbf{X}$ & $\mathbf{X}$ & -- & -- & -- & $\mathbf{X}$ & $\mathbf{X}$ & $\mathbf{X}$ & - & -- & $\mathbf{X}$ & -- & $\mathbf{X}$ & $\mathbf{X}$ & $\mathbf{X}$ \\
\hline Magnetite - & - & - & -. & - & - & - & -. & $\mathbf{X}$ & $\mathbf{X}$ & $\mathbf{X}$ & - & - & -- & -- & $\mathbf{X}$ & $\mathbf{X}$ & - & $\mathbf{X}$ & -- & -- \\
\hline Other minerals & & & & & & & & & & & & & & & & & & & & \\
\hline Epidote - - & -- & -- & -- & $\mathbf{X}$ & -- & -- & $\mathbf{X}$ & $\mathbf{X}$ & $\mathbf{X}$ & $\mathbf{X}$ & - & -- & -- & -- & -- & -- & -- & $\mathbf{X}$ & $\mathbf{x}$ & $\mathbf{X}$ \\
\hline Titanite(?) - & - & -- & -- & -- & -- & - & -- & - & $\mathbf{X}$ & - & -- & -- & - & -- & -- & -- & -- & $\mathbf{X}$ & -- & - \\
\hline Garnet(?) & -. & -- & $\mathbf{X}$ & -- & -- & -- & -- & -- & -- & -- & -- & -- & -- & -- & -- & -- & -- & -- & -- & -- \\
\hline 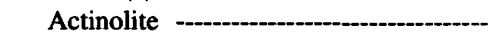 & - & -- & - & -- & -- & -. & - & $\mathrm{X}$ & $\mathbf{X}$ & $\mathrm{X}$ & - & -- & -- & -- & -- & - & -- & $\mathbf{X}$ & -- & -- \\
\hline Prehnite & - & -- & -- & -- & $\mathbf{X}$ & -- & $\mathbf{X}$ & -- & -- & - & -- & - & -- & - & -- & - & -- & $\mathbf{X}$ & $\mathbf{X}$ & -- \\
\hline Adularia --- & -- & -- & -- & -- & -- & -- & -- & -- & -- & -- & -. & -- & -- & -- & -- & -- & -- & $\mathbf{X}$ & $\mathbf{X}$ & -- \\
\hline 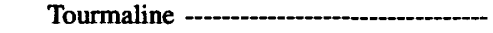 & -- & - & - & -- & -- & -- & -- & -- & -- & -- & -- & -- & -- & -- & -- & -- & -- & $\mathbf{X}$ & -- & -- \\
\hline 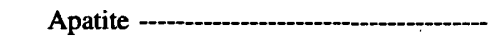 & - & - & -- & - & - & -- & - & -- & -- & -- & -- & -- & -- & -- & -- & -- & -- & $\mathbf{X}$ & -- & -- \\
\hline Chrysocolla - & -- & -- & -- & -- & - & $\mathbf{X}$ & - & -- & -- & -- & -- & -- & -- & -- & - & -- & -- & -- & -- & -- \\
\hline 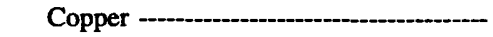 & -- & -- & - & -- & -- & -- & $\mathbf{X}$ & -- & -- & - & -- & -- & -- & - & -- & -- & -- & -- & -- & -- \\
\hline
\end{tabular}

${ }^{1}$ Drill holes numbered 1 to 13 are the same as those listed in table 1; locations are shown in fig. 1. Letter designations correspond to: A, Cheeney Creek mining area; B, Lost Creek area; C, Cast Creek-Short Creek area; D, Lolo Pass; E, Laurel Hill; F, Iron Creek; G, Barlow Pass-Bennett Pass area. 


\section{SELECTED SERIES OF U.S. GEOLOGICAL SURVEY PUBLICATIONS}

\section{Periodicals}

Earthquakes \& Volcanoes (issued bimonthly).

Preliminary Determination of Epicenters (issued monthly).

\section{Technical Books and Reports}

Professional Papers are mainly comprehensive scientific reports of wide and lasting interest and importance to professional scientists and engineers. Included are reports on the results of resource studies and of topographic, hydrologic, and geologic investigations. They also include collections of related papers addressing different aspects of a single scientific topic.

Bulletins contain significant data and interpretations that are of lasting scientific interest but are generally more limited in scope or geographic coverage than Professional Papers. They include the results of resource studies and of geologic and topographic investigations, as well as collections of short papers related to a specific topic.

Water-Supply Papers are comprehensive reports that present significant interpretive results of hydrologic investigations of wide interest to professional geologists, hydrologists, and engineers. The series covers investigations in all phases of hydrology, including hydrogeology, availability of water, quality of water, and use of water.

Circulars present administrative information or important scientific information of wide popular interest in a format designed for distribution at no cost to the public. Information is usually of shortterm interest.

Water-Resource Investigations Reports are papers of an interpretive nature made available to the public outside the formal USGS publications series. Copies are reproduced on request unlike formal USGS publications, and they are also available for public inspection at depositories indicated in USGS catalogs.

Open-File Reports include unpublished manuscript reports, maps, and other material that are made available for public consultation at depositories. They are a nonpermanent form of publication that may be cited in other publications as sources of information.

\section{Maps}

Geologic Quadrangle Maps are multicolor geologic maps on topographic bases in 7 1/2-or 15 -minute quadrangle formats (scales mainly $1: 24,000$ or $1: 62,500$ ) showing bedrock, surficial, or engineering geology. Maps generally include brief texts; some maps include structure and columnar sections only.

Geophysical Investigations Maps are on topographic or planimetric bases at various scales; they show results of surveys using geophysical techniques, such as gravity, magnetic, seismic, or radioactivity, which reflect subsurface structures that are of economic or geologic significance. Many maps include correlations with the geology.

Miscellaneous Investigations Series Maps are on planimetric or topographic bases of regular and irregular areas at various scales; they present a wide variety of format and subject matter. The series also includes 7 1/2-minute quadrangle photogeologic maps on planimetric bases that show geology as interpreted from aerial photographs. Series also includes maps of Mars and the Moon.
Coal Investigations Maps are geologic maps on topographic or planimetric bases at various scales showing bedrock or surficial geology, stratigraphy, and structural relations in certain coal-resource areas.

Oil and Gas Investigations Charts show stratigraphic information for certain oil and gas fields and other areas having petroleum potential.

Miscellaneous Field Studies Maps are multicolor or black-andwhite maps on topographic or planimetric bases on quadrangle or irregular areas at various scales. Pre-1971 maps show bedrock geology in relation to specific mining or mineral-deposit problems; post-1971 maps are primarily black-and-white maps on various subjects, such as environmental studies or wilderness mineral investigations.

Hydrologic Investigations Atlases are multicolor or black-andwhite maps on topographic or planimetric bases presenting a wide range of geohydrologic data of both regular and irregular areas; principal scale is 1:24,000, and regional studies are at 1:250,000 scale or smaller.

\section{Catalogs}

Permanent catalogs, as well as some others, giving comprehensive listings of U.S. Geological Survey publications are available under the conditions indicated below from the U.S. Geological Survey, Books and Open File Reports Sales, Federal Center, Box 25286, Denver, CO 80225. (See latest Price and Availability List.)

"Publications of the Geological Survey, 1879-1961" may be purchased by mail and over the counter in paperback book form and as a set of microfiche.

"Publications of the Geological Survey, 1962-1970" may be purchased by mail and over the counter in paperback book form and as a set of microfiche.

"Publications of the Geological Survey, 1971-1981" may be purchased by mail and over the counter in paperback book form (two volumes, publications listing and index) and as a set of microfiche.

Supplements for $1982,1983,1984,1985,1986$, and for subsequent years since the last permanent catalog may be purchased by mail and over the counter in paperback book form.

State catalogs, "List of U.S. Geological Survey Geologic and Water-Supply Reports and Maps For (State)," may be purchased by mail and over the counter in paperback booklet form only.

"Price and A vailability List of U.S. Geological Survey Publications," issued annually, is available free of charge in paperback booklet form only.

Selected copies of a monthly catalog "New Publications of the U.S. Geological Survey" are available free of charge by mail or may be obtained over the counter in paperback booklet form only. Those wishing a free subscription to the monthly catalog "New Publications of the U.S. Geological Survey" should write to the U.S. Geological Survey, 582 National Center, Reston, VA 22092.

Note.--Prices of Government publications listed in older catalogs, announcements, and publications may be incorrect. Therefore, the prices charged may differ from the prices in catalogs, announcements, and publications. 


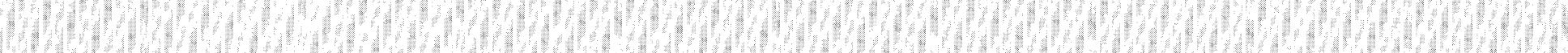

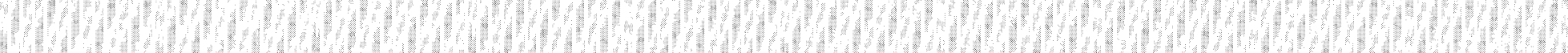

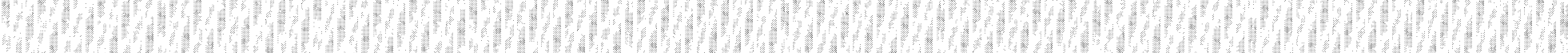

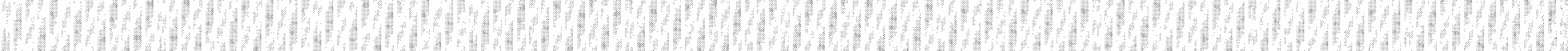

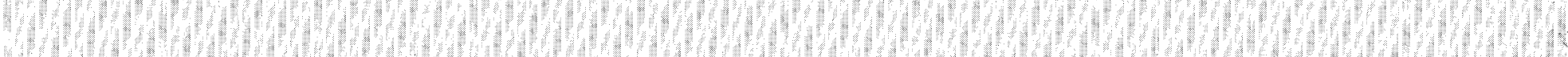

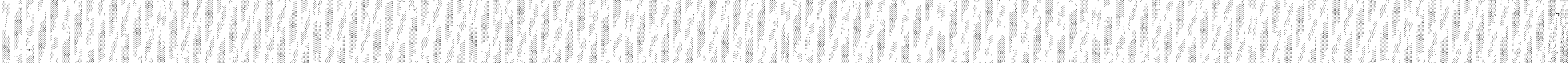

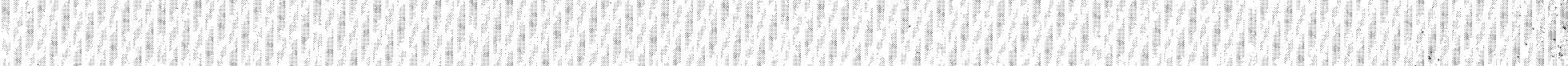

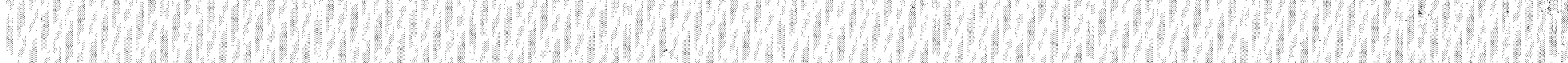

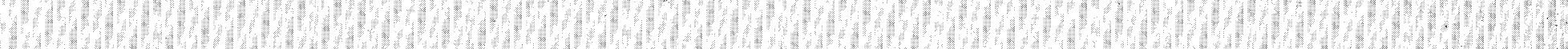

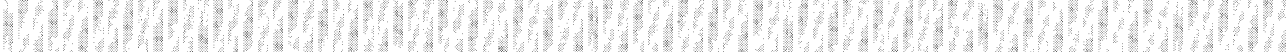

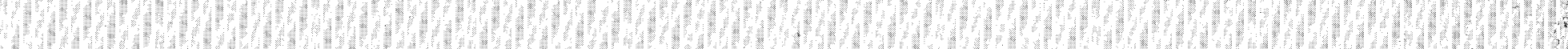

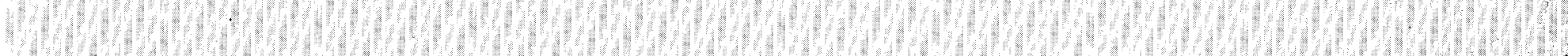

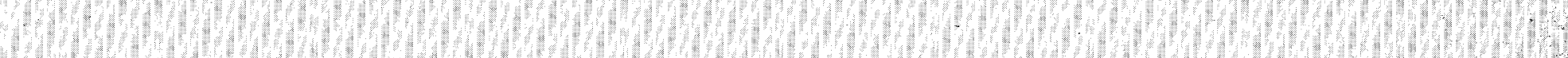

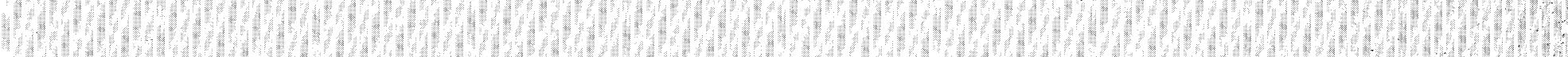

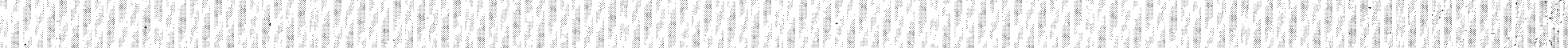

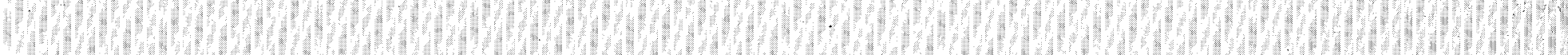

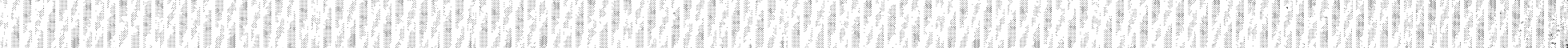

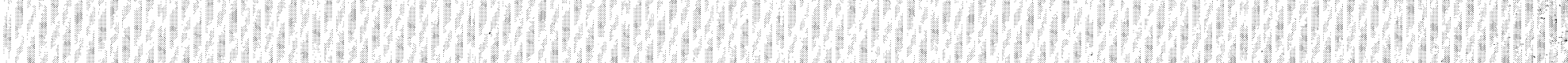

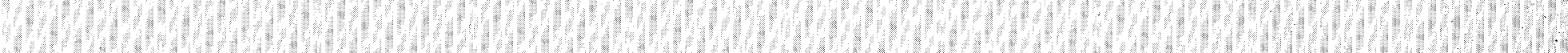

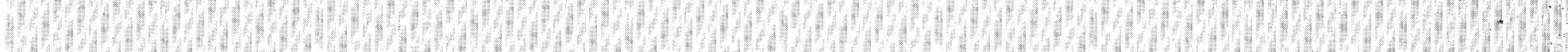

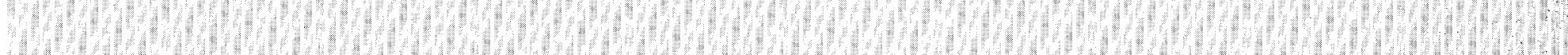

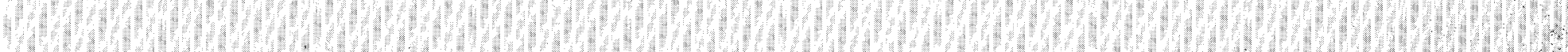

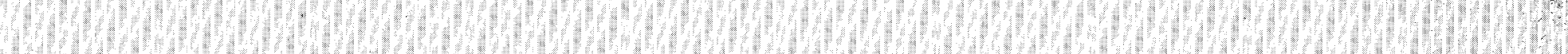

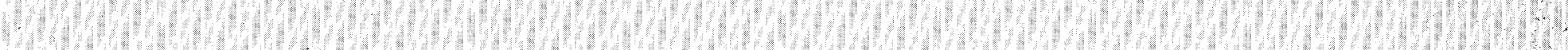

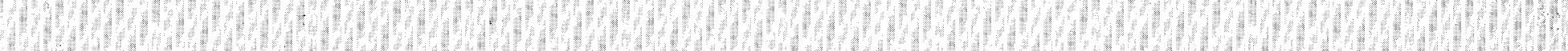

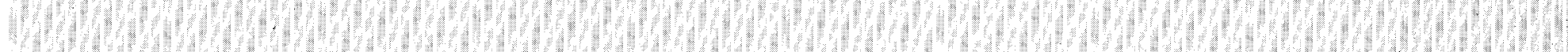

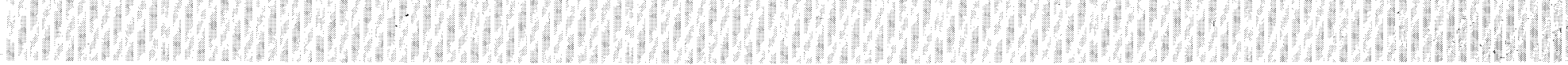

